UNIVERSIDADE DE SÃO PAULO

INSTITUTO DE PSICOLOGIA

ANA ELISA SESTINI

\title{
Interação social e comunicação na primeira infância
}




\section{ANA ELISA SESTINI}

\section{Interação social e comunicação na primeira infância}

Tese apresentada ao Instituto de Psicologia da Universidade de São Paulo, como parte dos requisitos para obtenção do título de Doutor em Psicologia.

Área de Concentração: Psicologia

Experimental.

Orientadora: Vera Silvia Raad Bussab. 
AUTORIZO A REPRODUÇÃO E DIVULGAÇÃO TOTAL OU PARCIAL DESTE TRABALHO, POR QUALQUER MEIO CONVENCIONAL OU ELETRÔNICO, PARA FINS DE ESTUDO E PESQUISA, DESDE QUE CITADA A FONTE.

Catalogação na publicação

Serviço de Biblioteca e Documentação

Instituto de Psicologia da Universidade de São Paulo

Sestini, Ana Elisa.

Interação social e comunicação na primeira infância / Ana Elisa Sestini; orientadora Vera Silva Raad Bussab. -- São Paulo, 2008.

$257 \mathrm{p}$.

Tese (Doutorado - Programa de Pós-Graduação em Psicologia. Área de Concentração: Psicologia Experimental) - Instituto de Psicologia da Universidade de São Paulo.

1. Interação social 2. Comunicação não-verbal 3. Comunicação verbal 4. Infância 5. Brincadeiras 6. Etologia humana I. Título.

HM252 


\section{Ana Elisa Sestini}

\section{Interação social e comunicação na primeira infância}

Tese apresentada ao Instituto de Psicologia da Universidade de São Paulo, como parte dos requisitos para obtenção do título de Doutor em Psicologia.

Área de Concentração: Psicologia

Experimental.

BANCA EXAMINADORA

Prof. Dr.

Instituição: Assinatura:

Prof. Dr.

Instituição: Assinatura:

Prof. Dr.

Instituição: Assinatura:

Prof. Dr.

Instituição: Assinatura:

Prof. Dr.

Instituição: Assinatura:

Tese defendida e aprovada em: l 
Dedico este trabalho a todas as crianças do mundo, com o desejo profundo de que cada uma delas viva a rica experiência do brincar.

Também o dedico às pessoas que cuidam de crianças e respeitam-nas por inteiro. 


\section{PREFÁCIO}

Primeiro, gostaria de me apresentar, para quem não me conhece... Sou formada em Ciências Biológicas (IB-USP), mas “migrei” para a Psicologia desde o final do curso, quando realizei um trabalho de Iniciação à Pesquisa sobre etologia e cognição em macocos-prego (Cebus apella), sob orientação do Professor Eduardo Ottoni (IP-USP). Logo após me formar, e ainda sob a orientação do Edu, fiz Mestrado em Psicologia Experimental a respeito das capacidades cognitivas e comunicativas de um Papagaio Verdadeiro (Amazona aestiva). Depois de concluir o Mestrado, fiquei fora da Universidade durante 1 ano. Em 2003 voltei para o Instituto de Psicologia decidida a estudar o comportamento de crianças pequenas. Sempre gostei muito de crianças, mas sabia que pesquisar sobre esse assunto seria um desafio maior, pois não tenho formação em Psicologia. Realmente foi, porém não percorri este caminho sozinha: tive a orientação de duas excelentes pesquisadoras da área, a Professora Maria Almeida Carvalho, na primeira metade do percurso, e a Professora Vera Silvia Raad Bussab, na segunda metade. Sou profundamente grata a elas e é com grande satisfação que concluo este estudo.

Em segundo lugar, gostaria de avisar ao leitor, para que ele não fique muito impaciente, que esta Tese é o resultado de um trabalho de quase 5 anos que foi amadurecendo com o tempo. Nota-se isto, principalmente, na parte de análise dos resultados, na qual se investigou diferentes aspectos da comunicação e interação social entre as crianças observadas. Dei preferência a relacionar estes resultados com mais profundidade no item "discussão", comparando-os com a literatura existente na área. Além disso, optei por colocar boa parte dos dados que obtive, o que resultou em muitos Apêndices, mas, acredito, tornam trabalho mais transparente. 


\section{AGRADECIMENTOS}

Às minhas Orientadoras, Ana Maria Almeida Carvalho (até 2005) e Vera Silvia Raad Bussab (de 2005 a 2008), pela disponibilidade, compreensão, ensinamentos e por me guiarem pelos caminhos da primeira infância.

À Creche do I.P.T. por ter permitido que eu realizasse a pesquisa com suas crianças e em suas instalações.

À Rosely, na época coordenadora da creche, por seu apoio, simpatia e interesse.

Às educadoras que cuidaram das crianças do grupo Lilás, cooperaram, interferindo o mínimo possível durante as observações, e me auxiliaram no que fosse necessário. Um "muito obrigada" especial à Ângela, à Érica, à Marcia e à Cíntia.

Às crianças do grupo Lilás, por tudo o que aprendi com elas. E a seus pais, por terem autorizado que elas participassem como sujeitos na pesquisa.

À Maria de L. S. Morais e à Ana M. A. Carvalho, por suas preciosas contribuições por ocasião do exame geral de qualificação.

À minha amiga Rosana de Oliveira, pela ajuda fundamental que me deu nos momentos finais de conclusão da Tese. 
À minha mãe, pela compreensão, apoio, amor e incentivo nos momentos mais difíceis que passei.

Ao meu padrasto, pelos "helps", toques, dicas e insistência para que eu fosse mais objetiva.

Ao Althay e à Patrícia Izar, por terem me auxiliado na análise estatística dos dados.

À FAPESP pela imprescindível bolsa concedida e pareceres positivos.

A todas as pessoas que contribuíram de alguma forma para que esta pesquisa fosse realizada. 


\section{RESUMO}

SESTINI, A.E. Interação social a comunicação na primeira infância. 2008. 257 p. Tese (Doutorado) - Instituto de Psicologia, Universidade de São Paulo, São Paulo, 2008.

Esta pesquisa parte da visão da criança como agente ativo de seu próprio desenvolvimento. Buscou-se investigar a interação criança-criança, os processos formadores de "cultura" no grupo de brinquedo e o papel dos modos de comunicação verbal e não-verbal nestes processos de co-construção de significados compartilhados. Foram estudados os estilos de brincadeiras das crianças, as parcerias preferenciais entre elas e as mudanças nas formas de comunicação durante o período estudado. Os sujeitos foram crianças de 1 a 3 anos de idade, acompanhados semanalmente, durante 1 ano e meio, numa creche em São Paulo. Foram realizadas filmagens das crianças em momentos de atividade lúdica livre (com pouca interferência das educadoras), utilizando-se os métodos de amostragem "focal" e "varredura instantânea". Além disso, foram feitas sessões de observação semicontrolada, filmando-se, separadamente, duplas de crianças com maior ou menor afinidade social, brincando com 10 pares de objetos pré-selecionados. Os resultados mostram que as crianças comunicaram-se mais entre si do que com adultos, tanto de modo verbal quanto não-verbal. Do período inicial de coleta de dados para o final, houve uma diminuição significativa de comportamentos não-verbais indicativos de comunicação e um aumento significativo de episódios de verbalização. No período inicial, houve uma freqüência significativamente maior de verbalizações em contextos de interações agonísticas e imperativas, e no período final houve uma frequiência significativamente maior de verbalizações de convite para interação. Verificou-se um aumento da comunicação verbal quando as crianças estavam com idades entre 1 ano e 10 meses (a mais nova) e 2 anos e 6 meses (a mais velha). Quanto ao comportamento não-verbal, as crianças se comunicaram mais por olhares e expressões faciais, no entanto, no período inicial houve uma frequiência significativamente maior de vocalizações, no período intermediário houve uma frequiência significativamente maior de gestos e acenos e, no período final, de imitações. A imitação foi considerada como um meio das crianças compartilharem significados e de iniciarem ou manterem interações sociais. A situação de duplas foi favorecedora de episódios de imitação e ocorreu maior freqüência de interações sociais após imitação principalmente quando as crianças estavam com idades próximas a 3 anos. Em relação aos estilos de brincadeiras, duplas com maior afinidade social apresentaram freqüência significativamente maior de brincadeiras de contingência social do que duplas com menor afinidade; duplas formadas apenas por meninas brincaram mais de faz-de-conta, duplas formadas somente por meninos brincaram mais de brincadeiras paralelas e duplas mistas brincaram mais de brincadeiras do tipo "física". Quando em grupo, as meninas brincaram mais com outras crianças do que sozinhas, diferentemente dos meninos. Foram identificadas e descritas qualitativamente algumas formas de brincadeiras particulares do grupo estudado. A conclusão foi que crianças dessa faixa etária são capazes de construir e compartilhar significados no grupo, mesmo antes de dominarem a comunicação verbal. Porém, também há indícios de que a fala facilite os processos de compartilhamento e persistência de significados no grupo e favoreça o aumento da complexidade das brincadeiras entre as crianças.

Palavras-chave: Interação criança-criança. Comunicação. Cultura de pares. 


\begin{abstract}
SESTINI, A.E. Social interaction and communication in early childhood. 2008. 257 p. Doctoral Thesis - Instituto de Psicologia, Universidade de São Paulo, São Paulo, 2008.

This research is based on the view of the child as an active agent of his/her own development. It aimed to investigate the child-child interaction, the processes of "culture" creation within the playgroup and the role of verbal and nonverbal forms of communication in those processes of joint construction of shared meanings. The style of the children's play, the preferential partnerships between them and the changes in the forms of communication during the study period were examined. The subjects were 1-to-3-year-old children, weekly monitored over a year and a half at a daycare center in São Paulo. The children were videorecorded during free-play activity (with little interference from the educators), and the "focalsubject" and "scan-sampling" methods were used. In addition, semi-controlled observation sessions were conducted, and pairs of children with greater or smaller social affinity were separately recorded playing with ten pairs of pre-selected objects. Results show that the children communicated more between themselves than with adults, both verbally and nonverbally. From the period the data started to be collected to the end of the study, a significant decrease in nonverbal behaviors indicative of communication and a significant increase in verbalization episodes were observed. A significantly higher frequency of verbalizations in contexts of agonistic and imperative interactions was observed in the initial period, whereas a significantly higher frequency of verbalizations of invitation to interaction was observed in the final period. The verbal communication increased when the children were 1 year and 10 months old (youngest child) to 2 years and 6 months old (oldest child). As for nonverbal behavior, the children's communication was predominantly through looks and facial expressions, however there has been a significantly higher frequency of vocalizations in the initial period, a significantly higher frequency of gestures and nods and waves in the intermediary period and of imitations in the final period. Imitation was considered a means through which children share meanings and start or maintain social interactions. The situation of pairs favored episodes of imitation and social interactions were more frequent after imitation mainly when the children were near 3 years of age. Concerning play styles, pairs with greater social affinity produced a significantly higher frequency of social-contingency play than pairs with smaller affinity; pairs formed only by girls did more make-believe play, pairs formed only by boys did more parallel play and mixed pairs did more "physical" play. When the girls were in group, they played more with other children than when they were alone, differently from the boys. Some forms of play particular to the studied group were identified and qualitatively described. The research concluded that children in this age bracket are able to build and share meanings within the group, even before mastering the verbal communication. However, there are also signs that the speech facilitates the sharing processes and the persistence of meanings within the group and leads to more complex play between the children.
\end{abstract}

Key words: Child-child interaction. Communication. Peer culture. 


\section{LISTA DE FIGURAS}

Figura

Página

$\mathbf{n}^{\mathbf{0}}$

1 - Atenção: Sílvio observando Gisele bater embalagem de xampu no chão

2 - Expressão facial: Laura emitindo sorriso aberto para a câmera (pesquisadora)

3 - Gesto: Laura acenando (tchau) - para educadora.

4 - Movimento: Carlos empurrando Gisele

5 - Postura: Gisele vira cabeça e corpo para olhar educadora ao longe.

6 - Total do número de eventos (soma dos eventos apresentados por todas as crianças) registrados para cada categoria, nos períodos inicial e final de observação.

7 - Comparação entre o número de eventos de comunicação verbal e não-verbal nos períodos inicial e final de observações.

8 - Comparação da frequiência absoluta de comunicação não-verbal (excluindo os valores de atenção) no período de observação inicial e no final para cada criança (A, C, Gi, H, La e S).

9 - Comparação da frequiência absoluta de comunicação verbal nos períodos de observação inicial e final para cada criança (A, C, Gi, H, La e S).

10 - Histograma das freqüências relativas das categorias de atenção (e de eventos não codificáveis) obtidos para as duplas com maior e para aquelas com menor afinidade social, na primeira (F1) e na sexta fase (F6) de observação em situação semicontrolada.

11 - Freqüências relativas das categorias dos comportamentos não-verbais indicativos de comunicação obtidos nos focais $(\mathrm{F})$ iniciais $(21 / 8 / 03$ a 22/9/03), intermediários $(25 / 3 / 04$ a 28/4/04) e finais (13/10/04 a 16/11/04), das crianças A, C, Gi, H, La e S.

12 - Freqüências relativas dos comportamentos não-verbais indicativos de comunicação obtidos nos focais iniciais (21/8/03 a 22/9/03), intermediários (25/3/04 a 28/4/04) e finais (13/10/04 a 16/11/04), das crianças A, C, Gi, H, La e S.

13 - Freqüências relativas das categorias de referência dos comportamentos não-verbais indicativos de comunicação obtidos nos focais (F) iniciais (21/8/03 a 22/9/03), intermediários (25/3/04 a 28/4/04) e finais (13/10/04 a 16/11/04), das crianças A, C, Gi, H, La e S.

14 - Freqüências relativas das verbalizações dirigidas para adultos ou outras crianças, que acompanharam os comportamentos não-verbais indicativos de comunicação, obtidas nos focais $(\mathrm{F})$ iniciais (21/8/03 a 22/9/03), intermediários (25/3/04 a 28/4/04) e finais (13/10/04 a 16/11/04), das crianças A, C, Gi, H, La e S.

15 - Freqüências relativas das verbalizações direcionadas a outras crianças, para cada comportamento não-verbal indicativo de comunicação, obtidas nos focais (F) iniciais (21/8/03 a 22/9/03), intermediários (25/3/04 a 28/4/04) e finais (13/10/04 a 16/11/04), das crianças A, C, Gi, H, La e S. OBS.: Não foram representados na Figura os comportamentos não-verbais que não foram acompanhados de verbalizações em nenhum período 
16 - Frequiências relativas das verbalizações direcionadas a adultos, para cada comportamento nãoverbal indicativo de comunicação, obtidas nos focais $(\mathrm{F})$ iniciais (21/8/03 a 22/9/03), intermediários (25/3/04 a 28/4/04) e finais (13/10/04 a 16/11/04), das crianças A, C, Gi, H, La e S. OBS.: Não foram representados na Figura os comportamentos não-verbais que não foram acompanhados de verbalizações em nenhum período.

17 - Freqüências relativas das categorias de contexto dos episódios de verbalização ocorridos durante os focais iniciais ( $\mathrm{F}$ i: $21 / 8 / 03$ a 22/9/03), intermediários ( $\mathrm{F}$ int: 25/3/04 a 28/4/04) e finais ( $\mathrm{F} \mathrm{f}$ : 13/10/04 a 16/11/04), das crianças A, C, Gi, H, La e S.....

18 - Freqüências relativas das categorias de referência dos episódios de verbalização ocorridos durante os focais iniciais ( $\mathrm{F}$ i: $21 / 8 / 03$ a 22/9/03), intermediários ( $\mathrm{F}$ int: $25 / 3 / 04$ a 28/4/04) e finais ( $\mathrm{F} \mathrm{f}$ : 13/10/04 a 16/11/04), das crianças A, C, Gi, H, La e S

19 - Freqüências relativas do total de episódios de verbalização ocorridos durante os focais iniciais (F iniciais: 21/8/03 a 22/9/03), intermediários ( $\mathrm{F}$ intermediários: $25 / 3 / 04$ a 28/4/04) e finais ( $\mathrm{F}$ finais: 13/10/04 a 16/11/04), das crianças A, C, Gi, H, La e S.

20 - Sociograma obtido a partir dos valores de proximidade provenientes dos registros por varredura realizados no início e no fim das sessões de observações em situação lúdica livre, no período de 8/7/04 a 16/11/04 (32 scans). Foram representadas apenas as proximidades dos pares cujos valores eram maiores do que a média $(\mathrm{M}=2,5)$.

21 - Sociogramas obtidos a partir do registro (I) de todas as ocorrências de proximidade (20 minutos, exceto tempo dos scans) durante a primeira sessão conjunta (16/12/04, manhã) e (II) das proximidades verificadas nos scans realizados na mesma sessão. Foram representadas apenas as proximidades dos pares cujos valores eram maiores do que a média $(M=5,7)$. B faltou, A esteve ausente durante quase 10 minutos.

22 - Sociogramas obtidos a partir do registro (I) de todas as ocorrências de proximidade (20 minutos, exceto tempo dos scans) durante a segunda sessão conjunta (16/12/04, tarde) e (II) das proximidades verificadas nos scans realizados na mesma sessão. Foram representadas apenas as proximidades dos pares cujos valores eram maiores do que a média $(\mathrm{M}=6,0)$. B faltou.

23 - Freqüência relativa dos tipos de brincadeiras, obtida para díades preferenciais (DP - maior afinidade social) e não-preferenciais (DnP - menor afinidade social) a partir da análise dos 10 minutos iniciais da última sessão de cada dupla de crianças que participaram das sessões de observação em condição semicontrolada (22 sessões ao todo).

24 - Freqüência relativa dos tipos de brincadeira, obtida para cada faixa de diferença de idade existente entre as crianças que fizeram parte da mesma díade, a partir da análise dos 10 minutos iniciais da última sessão de cada dupla que participou das sessões de observação em condição semicontrolada (22 sessões ao todo). 100

25 - Freqüência relativa (porcentagem) das formas de brincadeiras - solitária (I), acompanhada (II) e solitária com interação (III) - nos quatro primeiros (P) focais $(21 / 8 / 03$ a 22/9/03), quatro focais intermediários (M; 25/3/04 a 28/4/04) e quatro últimos (U) focais (13/10/04 a 16/11/04) para cada criança (meninas: A, Gi, La; meninos: $\mathrm{C}, \mathrm{H}$ e $\mathrm{S}$ ). 
26 - Número de verbalizações detectadas nos quatro primeiros $(\mathrm{P})$ focais $(21 / 8 / 03$ a $22 / 9 / 03)$, quatro focais intermediários (M, 25/3/04 a 28/4/04) e quatro últimos (U) focais (13/10/04 a 16/11/04) de cada criança (A, C, Gi, H, La e S), durante brincadeira solitária (I), acompanhada (II) e solitária com interação (III). Não foram consideradas as verbalizações dirigidas a adultos (educadoras, funcionários, pesquisadora) 109

27 -Número de ausência de verbalizações detectadas nos quatro primeiros (P) focais (21/8/03 a 22/9/03), quatro focais intermediários (M, 25/3/04 a 28/4/04) e quatro últimos (U) focais (13/10/04 a 16/11/04) de cada criança (A, C, Gi, H, La e S), durante brincadeira solitária (I), acompanhada (II) e solitária com interação (III). Não foram consideradas as verbalizações dirigidas a adultos (educadoras, funcionários, pesquisadora).

28 - Comparação das freqüências relativas das categorias de brincadeiras analisadas nos focais do último semestre.

29 - Frequiências relativas das categorias de brincadeiras analisadas nos focais do último semestre, comparando-se os valores obtidos para os sujeitos-focais do sexo feminino (Sf) e masculino (Sm). 


\section{LISTA DE TABELAS}

$\mathbf{n}^{\mathbf{0}}$

1 - Características das quatro creches visitadas ( $1^{\circ}$ Semestre de 2003)

2 - Sujeitos, suas datas de nascimento e idades na primeira e última sessão em que foram observados. OBS: Organização em ordem decrescente segundo a idade das crianças.

3 - Frequiências absoluta e relativa do número de vezes que cada sessão de observação de atividade lúdica livre foi realizada em um dos cinco locais disponíveis na creche.

4 - Ordem de participação das duplas de crianças e semanas, dias e períodos em que foram observadas.

5 - Semanas, dias e períodos de observações em situação semicontrolada e as duplas que participaram em cada um deles e em cada fase. Os sinais entre parênteses indicam maior (+) ou menor (-) proximidade, segundo a avaliação feita a partir dos scans e o julgamento das educadoras

6 - Categorias comportamentais utilizadas para registrar os modos de comunicação verbal e nãoverbal de três meninos (C, H e S) e três meninas (A, Gi e La) com idades entre 14 e 26 meses.

7 - $\chi^{2}$ das categorias de atenção e do grau de afinidade social das duplas de crianças consideradas.

8 - Número de episódios de imitação detectados nas duplas com maior afinidade social e nas duplas com menor afinidade, na $1^{\mathrm{a}}$ e $6^{\mathrm{a}}$ fases de sessões de díades.

9 - Freqüência relativa (em relação ao total de não-verbais detectados em cada período de focais) das categorias dos comportamentos não-verbais indicativos de comunicação obtidos nos focais iniciais (21/8/03 a 22/9/03), intermediários (25/3/04 a 28/4/04) e finais (13/10/04 a 16/11/04), das crianças A, C, Gi, H, La e S.

10 - Distribuição das categorias de comportamentos não-verbais indicativos de comunicação nos períodos de focais iniciais (21/8/03 a 22/9/03), intermediários (25/3/04 a 28/4/04) e finais $(13 / 10 / 04$ a $16 / 11 / 04)$.

11 - Distribuição das categorias de referência dos comportamentos não-verbais indicativos de comunicação nos períodos de focais iniciais (21/8/03 a 22/9/03), intermediários (25/3/04 a 28/4/04) e finais $(13 / 10 / 04$ a 16/11/04).

12 - Freqüências absoluta $(\mathrm{Fa})$ e relativa $(\mathrm{Fr})$ de verbalizações dirigidas a outras crianças ou a adultos (educadoras ou pesquisadora), que acompanharam os comportamentos não-verbais indicativos de comunicação, obtidas nos focais iniciais (21/8/03 a 22/9/03), intermediários (25/3/04 a 28/4/04) e finais (13/10/04 a 16/11/04), das crianças A, C, Gi, H, La e S.

13 - Distribuição das verbalizações (para criança ou para adulto) que acompanharam os comportamentos não-verbais indicativos de comunicação, nos períodos de focais iniciais $(21 / 8 / 03$ a 22/9/03), intermediários (25/3/04 a 28/4/04) e finais (13/10/04 a 16/11/04)......

14 - Frequiência absoluta $(\mathrm{Fa})$ e relativa (Fr - em relação ao total de episódios de verbalização de cada período de focais) das categorias de contexto dos episódios de verbalização ocorridos durante os focais iniciais $(21 / 8 / 03$ a 22/9/03), intermediários (25/3/04 a 28/4/04) e finais (13/10/04 a 16/11/04), das crianças A, C, Gi, H, La e S. 
15 - Distribuição das categorias de contexto dos episódios de verbalização das crianças, nos períodos de focais iniciais (21/8/03 a 22/9/03), intermediários (25/3/04 a 28/4/04) e finais (13/10/04 a $16 / 11 / 04)$.

16 - Freqüência absoluta (Fa) e relativa (Fr - em relação ao total de episódios de verbalização de cada período de focais) das categorias de referência dos episódios de verbalização ocorridos durante os focais iniciais (21/8/03 a 22/9/03), intermediários (25/3/04 a 28/4/04) e finais (13/10/04 a 16/11/04), das crianças A, C, Gi, H, La e S.

17 - Distribuição das categorias de referência dos episódios de verbalização das crianças, nos períodos de focais iniciais (21/8/03 a 22/9/03), intermediários (25/3/04 a 28/4/04) e finais (13/10/04 a 16/11/04).

18 - Número de vezes (acima da média) que cada par de crianças foi visto próximo nos registros feitos por varredura (32 scans) nas sessões de observação de atividade lúdica livre (8/7/04 a 16/11/04) e durante as sessões conjuntas (todas as ocorrências, excluindo observações feitas por varredura; 16/12/04). (Em destaque, as freqüências de proximidade que se mantiveram acima da média nas três situações).

19 - Número de vezes que o sujeito-focal (a primeira sigla a aparecer em cada par na tabela) foi visto brincando com outra criança nos quatro primeiros focais (21/8/03 a 22/9/03), quatro focais intermediários (25/3/04 a 28/4/04) e quatro últimos focais (13/10/04 a 16/11/04). O sujeito-focal é representado pela primeira sigla a aparecer em cada par na tabela.

20 - Número de vezes que cada par de crianças brincou junto durante os primeiros focais, intermediários e últimos focais. As duplas marcadas com cor correspondem àquelas que foram vistas brincando juntas nos três períodos.

21 - Número de parceiros diferentes de brincadeira que cada criança teve nos três períodos analisados (primeiros focais, intermediários e últimos focais). As letras que aparecem entre parênteses correspondem às crianças que não foram consideradas como sujeitos-focais por não terem permanecido no grupo do início ao fim do período de coleta de dados. 108

22 - Categorias de objetos com os quais se observou as crianças brincando nas sessões de observação de atividade lúdica livre (focais do último semestre), número de ações usuais (comuns) ou não efetuadas sobre os objetos de acordo com o sexo das crianças $\left(S_{\mathrm{f}}=\right.$ feminino; $S_{\mathrm{m}}=$ masculino) e total de cada tipo de uso, dos sujeitos-focais que foram observados brincando com os objetos. 115

23 - Frequiências absolutas (Fa) e relativas (Fr) das categorias de brincadeiras analisadas, obtidas nos focais do último semestre, com valores separados para as meninas (Sf) e para os meninos (Sm) como sujeitos-focais.

24 - Distribuição das categorias de brincadeiras, obtidas nos focais do último semestre, em relação ao gênero (sexo) das crianças.

25 - Freqüências absolutas e totais de cada categoria de brincadeira analisada em cada fase (focais e duplas). OBS.: Foram analisadas apenas as duplas que se repetiram no primeiro (duplas iniciais) e no segundo semestre (duplas finais): A-C, A-Gi, A-H, A-La, C-Gi, C-H, C-S, Gi-Gu, Gi-H, Gi-La,Gu-H, H-S e La-S.

26 - Distribuição das categorias de imitação obtidas nos focais iniciais (21/8/03 a 22/9/03), intermediários $(25 / 3 / 04$ a 28/4/04) e finais (13/10/04 a 16/11/04) e duplas iniciais e finais..... 


\section{SUMÁRIO}

1- INTRODUÇÃO

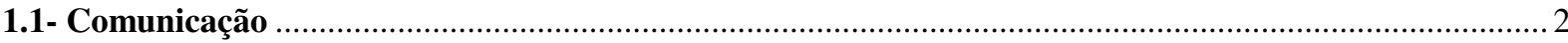

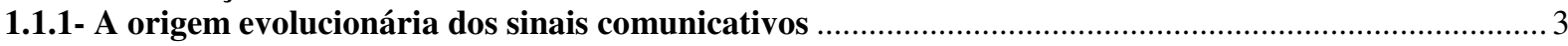

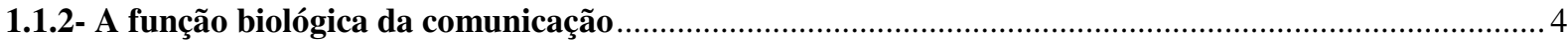

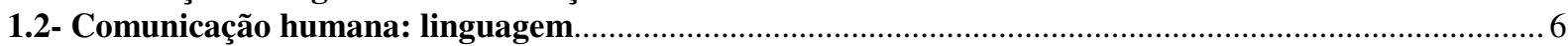

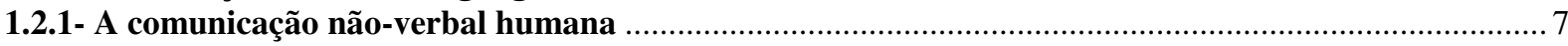

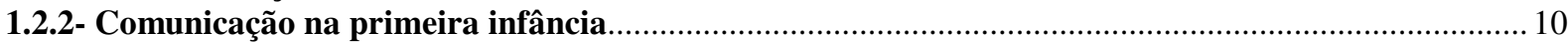

1.3- A criança como agente ativo de seu desenvolvimento: microcultura ............................................... 12

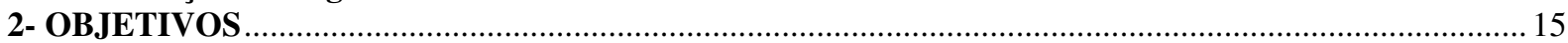

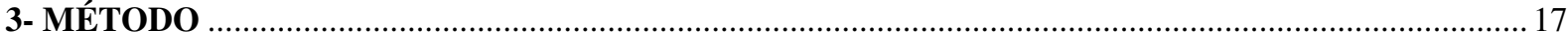

3.1- A procura de uma creche adequada para a realização da pesquisa .............................................. 17

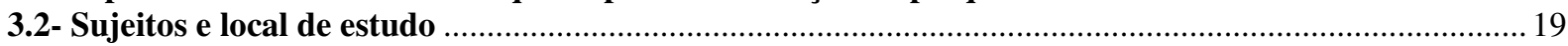

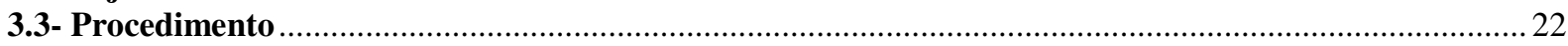

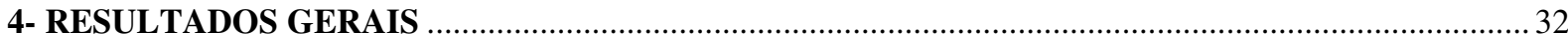

4.1- Observações em momentos de atividade lúdica livre .................................................................. 32

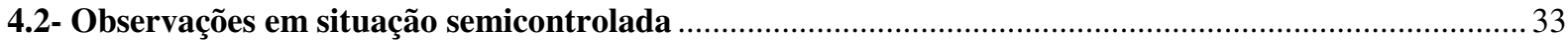

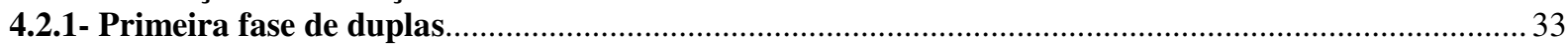

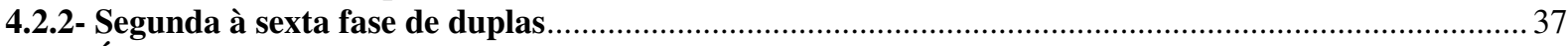

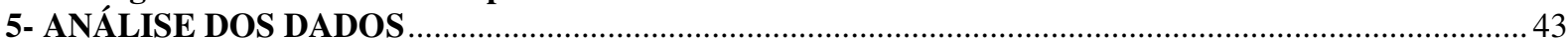

5.1- Análise da freqüência de comunicação verbal e não-verbal, no começo e no final do primeiro semestre

5.2- Orientação da atenção e afinidade social

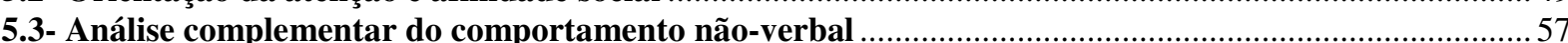

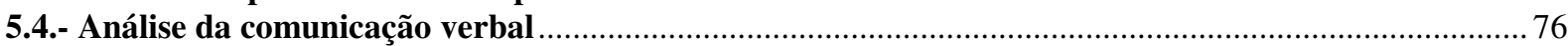

5.5.- Persistência de significados construídos no grupo ..................................................................... 90

5.6- Tipos de brincadeiras e efeitos do grau de preferência social e do distanciamento de idades.............. 99

5.7- Análise do brincar, das parcerias preferenciais e da forma de comunicação (verbal ou ausência de verbal)

5.8.- Brincadeiras usuais ou não-usuais com objeto e brincadeiras sem objeto .................................... 116

5.9.- Imitação de ações usuais ou não-usuais com objeto e de ações sem objeto ................................... 123

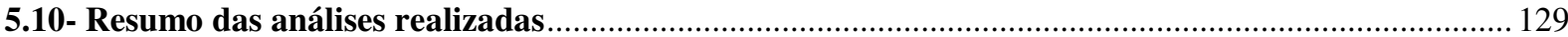

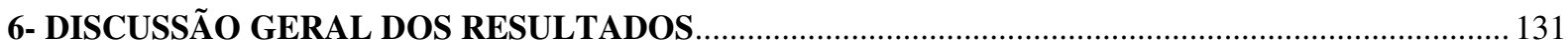

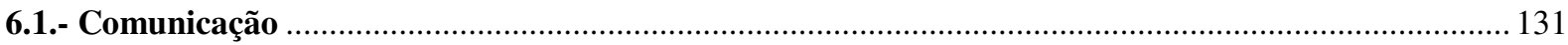

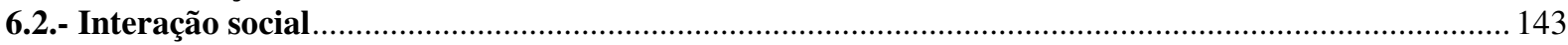

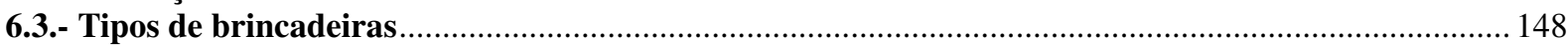

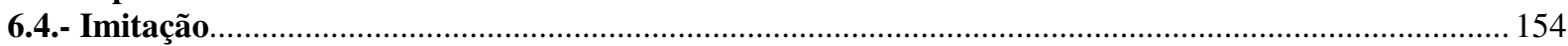

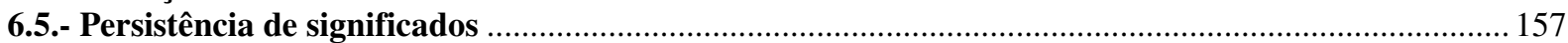

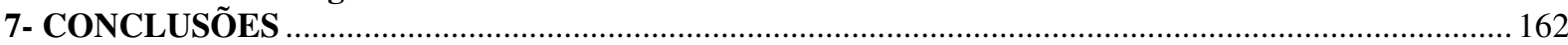

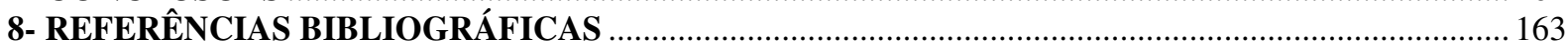

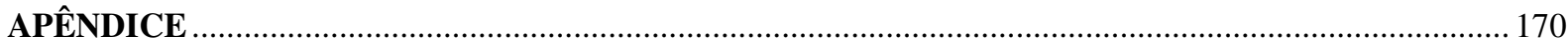




\section{1- INTRODUÇÃO}

Este trabalho visa investigar a interação social e os processos de comunicação entre pares de idade, na primeira infância, especialmente os modos de construção de significados e as relações entre comunicação verbal e não-verbal, a partir de um referencial etológicocomparativo e de desenvolvimentos teóricos e empíricos recentes da pesquisa sobre interação entre crianças, compatíveis com esse referencial e dele decorrentes.

De um ponto de vista etológico, comportamento social pode ser entendido como o comportamento que envolve dois ou mais animais, e através do qual eles influenciam uns aos outros (Hinde, 1974 e Deag, 1981). Ser uma espécie social, portanto, não significa apenas apresentar um modo de vida em grupo; é necessário que haja influências de um indivíduo sobre outro e vice-versa. Blurton-Jones (1981) afirma que a função principal do comportamento social parece ser a de alterar o comportamento de outros animais. Carvalho (1992) e Pedrosa, Carvalho e Império-Hamburger (1997) conceituam social como o espaço de informação construído pelos seres que têm a propriedade de sociabilidade, sendo esta entendida como a propriedade de regular e ser regulado pelo co-específico. Maturana (1999) refere-se a sistema social para designar o resultado de interações recorrentes que acontecem, com alguma freqüência, entre seres vivos. Em quaisquer dessas definições, os animais designados como "sociais" interagem entre si e influenciam-se mutuamente.

Embora por esses critérios o homem constitua uma espécie social, compartilhando este atributo com outras espécies, sua sociabilidade difere da dos outros animais. O que distingue e especifica o viver humano em relação aos demais, é o fato de seu viver não ser apenas social, mas sim sócio-cultural. Ainda que alguns autores tenham alegado a existência de cultura ${ }^{1} \mathrm{em}$

\footnotetext{
${ }^{1}$ A atribuição de cultura a alguns animais não-humanos decorre de uma definição mais ampla deste termo. Mainardi e Mainardi (1988) usam o termo cultura no sentido de um hábito socialmente transmitido numa população. Outros autores consideram cultura como um comportamento típico de um grupo ou população, obtido por transmissão social e não por alteração genética ou ambiental (Heyes, 1993).
} 
outros animais (p. ex., Kawamura, 1959; Mainardi e Mainardi, 1988; de Waal e Seres, 1997), o modo de vida cultural humano diferencia-se por ser altamente especializado, caracterizado pela transmissão de informações de geração a geração, via experiência, e pelo uso da linguagem e de outras representações simbólicas (Bussab e Ribeiro, 1998). A comunicação tipicamente humana apresenta-se, portanto, como essencial para a compreensão de sua especificidade sócio-cultural.

\section{1- Comunicação}

Todo comportamento social envolve comunicação, que pode ser entendida como "o desencadeamento mútuo de comportamentos coordenados que se dá entre membros de uma unidade social" (Maturana e Varela, 2004, pp. 214). A comunicação também pode ser definida como a transferência de informação, por meio de sinais, de um indivíduo para outro, alterando, neste, a probabilidade de um determinado comportamento (Deag, 1981). Estes sinais podem ser químicos (feromônios, odores e sabores), estruturais (por exemplo, a cauda do pavão) ou comportamentais (por exemplo, vocalizações, gestos e posturas). Hauser (1996) distingue "sinais" (signals) de "pistas" (cues). Os primeiros seriam produzidos em resposta a alterações ambientais de importância sócio-ecológica que variam temporalmente e sua expressão implicaria em custos significativos para o indivíduo. Enquanto os segundos seriam manifestados permanentemente, pois fariam parte do fenótipo de um indivíduo ou espécie e sua expressão não traria um custo imediato extra. De acordo com esta distinção, as vocalizações de alarme emitidas por muitos animais na presença de predadores constituem sinais, mas as cores de advertência presentes em vários animais venenosos, não. Já "informação" pode ser qualquer dado a respeito do ambiente, do estado motivacional, emocional, fisiológico ou da identidade do emissor. Assim, a comunicação pode ser 
classificada como referencial, quando informa sobre condições do ambiente externo, e expressiva, quando se relaciona a estados internos ou ações iminentes do emissor (Carvalho e Pedrosa, 2004). Ela também pode ser verbal ou não-verbal. Comunicação verbal pode ser definida, de modo simplificado, como aquela que ocorre por meio de palavras (sejam elas vocalizadas, gesticuladas ou escritas).

A comunicação, portanto, é bastante diversa; mas como será que ela surgiu?

\subsection{1- A origem evolucionária dos sinais comunicativos}

Comparando movimentos de display apresentados por uma espécie com aqueles de outras espécies filogeneticamente próximas e com outros movimentos presentes na mesma espécie, é possível elaborar hipóteses tanto a respeito da origem evolucionária de muitos sinais comunicativos, quanto sobre as mudanças que eles sofreram durante a evolução (Hinde, 1974). Segundo a perspectiva etológica, uma destas hipóteses é que os sinais comunicativos tenham surgido a partir de padrões comportamentais manifestados em situações de conflito ${ }^{2}$ e que não possuíam, originalmente, função comunicativa (Carvalho, 1998). Tais padrões foram agrupados em três categorias:

- Movimentos de intenção - na presença de impulsos conflitantes, o animal pode alternar ou combinar componentes de padrões comportamentais desencadeados por emoções ou motivações contraditórias. Por exemplo, diante de um rival, o animal pode, ao mesmo tempo, avançar e recuar, devido a seus impulsos para atacar (agressividade) e fugir (medo).

\footnotetext{
${ }^{2}$ É importante destacar que o sentido da palavra "conflito" neste contexto nem sempre se relaciona a uma disputa entre indivíduos. O seu uso refere-se principalmente a fatores ou tendências internas nos animais, que resultam em dois ou mais comportamentos incompatíveis (Hinde, 1974).
} 
- Comportamentos deslocados - constituem ações irrelevantes em relação às motivações ou emoções presentes e que servem como válvulas de escape para o conflito. Por exemplo, uma criança intimidada e simultaneamente atraída por uma situação nova, chupa o dedo (Carvalho, 1998).

- Respostas autonômicas - são reações aparentes (ou seja, visíveis por um observador externo) do organismo, mediadas pelo sistema nervoso autônomo, como suar, eriçar os pelos, empalidecer, enrubescer, urinar e defecar.

Uma vez que estes padrões comportamentais ocorriam em situações sociais, eles foram adquirindo função comunicativa, através da ritualização, que é o processo pelo qual a forma, intensidade e orientação ambiental de posturas, gestos e outras expressões de estados emocionais são gradualmente, ao longo da filogenia, desconectados de fatores circunstanciais e tornam-se menos variáveis, mais estereotipados e mais conspícuos (Carvalho e Pedrosa, 1994). Carvalho, Império-Hamburger e Pedrosa (1996) afirmam que, do ponto de vista comparativo, é razoável atribuir parte da regulação que ocorre na interação social humana à mediação por gestos ou comportamentos filogeneticamente ritualizados, talvez especialmente nos primeiros anos de vida, quando o uso da linguagem verbal é ainda reduzido.

\subsection{2- A função biológica da comunicação}

Há pelo menos duas visões distintas quanto à função biológica da comunicação (Goodenough, McGuire e Wallace, 1993 e Hauser, 1996). Segundo uma perspectiva mais tradicional da Etologia, a função da comunicação é possibilitar que os animais compartilhem informações, sendo os sinais ritualizados considerados altamente informativos e não ambíguos (Hauser, 1996). Ao definir a função da comunicação deste modo subentende-se que 
os sinais emitidos a um co-específico sejam honestos, ou seja, que os indivíduos forneçam informações verdadeiras sobre o que ocorre dentro ou fora de si (sem nenhuma implicação de intencionalidade ou consciência).

Sinais honestos são vantajosos quando o emissor e o receptor são beneficiados por eles. No entanto, há situações em que o emissor pode ser mais bem sucedido se mentir. É isto o que supõe uma abordagem mais recente da Etologia. A partir da idéia da teoria evolucionária dos jogos elaborada por Maynard Smith (1976) e do gene egoísta (Dawkins, 1976), Dawkins e Krebs (1978) afirmaram que a função da comunicação é possibilitar que os animais manipulem o comportamento uns dos outros, em seu próprio benefício. Então, a seleção atuaria contra a emissão de sinais honestos e a favor do ocultamento das verdadeiras “intenções” do emissor (Hauser, 1996). Contudo, esta idéia foi logo criticada, pois parecia dar conta apenas de interações que ocorriam quando os animais estavam competindo entre si pela obtenção de algum recurso (parceiro sexual, alimento, abrigo etc). A fim de responder a estas críticas, Krebs e Dawkins (1984) explicaram que durante o processo de comunicação o receptor também exerce um papel ativo e a seleção natural atua a favor de animais bons “decodificadores” da verdadeira mensagem que está por trás dos sinais emitidos pelo emissor. Além disso, eles lançaram a hipótese de que os sinais emitidos durante interações competitivas seriam altos e exagerados, enquanto os sinais cooperativos seriam baixos e discretos. Assim, este modelo ajusta-se tanto a situações de competição quanto de cooperação entre os animais.

Diante do que foi exposto acima, parece que uma posição mais equilibrada seria conciliar as idéias mais tradicionais da Etologia com as mais recentes e admitir que durante o processo de comunicação, os animais podem emitir tanto sinais honestos quanto falsos e que os receptores precisam aprender a distinguir entre um tipo e o outro, agindo adequadamente em cada caso. Situações de conflito ou competição favoreceriam a emissão de sinais falsos e 
situações de cooperação favoreceriam a emissão de sinais honestos. Seja compartilhando informações ou manipulando uns aos outros, a comunicação é vantajosa pois possibilita, entre outras coisas, que os animais evitem entrar em conflitos físicos custosos e muitas vezes letais, cooperem para obter recursos que não poderiam ser conseguidos de outro modo ou estabeleçam relações sociais importantes para a perpetuação da espécie.

\section{2- Comunicação humana: linguagem}

A comunicação humana ocorre principalmente através da linguagem, que pode ser conceituada como um sistema comunicativo complexo e único na natureza, embora vários pesquisadores tenham demonstrado que alguns animais têm a capacidade de adquirir "linguagem" ou pelo menos uma forma de comunicação simbólica tipicamente humana (p. ex., chimpanzés, Pan troglodytes: Gardner e Gardner, 1984; Matsuzawa, 1985; Premack, 1983; Savage-Rumbaugh, Rumbaugh, Smith e Lawson, 1980, gorilas, Gorilla gorilla: Patterson, 1978; orangotangos, Pongo pygmaeus: Miles, 1983; golfinhos, Tursiops truncatus: Herman, 1987; leões-marinhos, Zalophus californianus: Schusterman e Krieger, 1984; e papagaios cinza africanos, Psittacus erithacus: Pepperberg, 1999). Tais resultados, somados ao fato destes animais viverem em grandes grupos na natureza e terem vidas longas, corroboram a idéia de que a complexidade comunicativa surja em resposta a interações sociais complexas e para mediá-las (Humphrey, 1978 apud Pepperberg, 1994).

Maturana e Varela (2004) e Maturana (1998) fornecem uma explicação bastante convincente para a origem da linguagem. Segundo estes autores, o modo de vida dos nossos ancestrais que viveram na África há três milhões e meio de anos ofereceu as condições que culminaram na produção da linguagem: um viver centrado na obtenção de alimentos principalmente a partir da coleta, no compartilhar de alimentos, na colaboração de machos e 
fêmeas na criação das crianças, em relações sexuais recorrentes (proporcionadas por um ciclo menstrual e não mais estral), numa sexualidade de encontro frontal, no âmbito de pequenos grupos ou famílias extensas, e na necessidade de fazer parte de um grupo e, ao mesmo tempo, afastar-se dele durante períodos razoavelmente longos para procurar alimento. Adicionalmente, Dunbar (1993) sugere que a linguagem evoluiu em conseqüência da necessidade de nossos ancestrais viverem em grupos sociais maiores e sua função seria a de aumentar a coesão social, pois permite que os indivíduos conheçam as características comportamentais de outros membros do grupo de uma maneira mais rápida do que seria possível apenas pela observação. Morin (1973) supõe que os primeiros hominídeos comunicavam-se por um sistema de chamados (call system), além de gestos e posturas corporais, e que a linguagem foi surgindo à medida que esta forma de comunicação deixou de ser suficiente diante da crescente complexidade social da sociedade humana.

\subsection{1- A comunicação não-verbal humana}

Embora a linguagem seja a forma de comunicação humana mais evidente, continuamos a nos comunicar por vias não-verbais - por exemplo, gestos, posturas e expressões faciais - mesmo depois de dominarmos o código verbal. Birdwhistell (1974 apud Davis, 1979) afirma que, numa conversa frente a frente, $35 \%$ das mensagens transmitidas são verbais e $65 \%$ não-verbais. A comunicação não-verbal humana é comparável àquela encontrada em outras espécies animais, no entanto apresenta maior complexidade e diversidade. Isto se deve a ela ser, muitas vezes, parte integral das trocas linguísticas (Hinde, 1974 e Brannigan e Humphries, 1981).

Vários autores estudaram a comunicação não-verbal humana. Darwin (2000) talvez tenha sido o primeiro a considerá-la sob um ponto de vista evolucionário comparativo. Em 
seu famoso livro “A Expressão das Emoções no Homem e nos Animais”, publicado em 1872, ele propõe que algumas de nossas expressões - como o mostrar os dentes caninos quando com raiva - tenham sido herdadas de antepassados comuns ao homem e a outros animais. Eibl-Eibesfeldt (1989), estudou a comunicação não-verbal humana que ocorre através do olfato, do tato e da visão, tendo dado atenção especial aos aspectos universais das expressões faciais nas diversas culturas humanas. Brannigan e Humphries (1981), listaram e descreveram detalhadamente 136 categorias de comportamento não-verbal humano, distinguindo, por exemplo, diversos tipos de sorrisos, de movimentos da sobrancelha e da cabeça. Harris (1996) pesquisou as relações entre expressões faciais e emoções.

Alguns aspectos da comunicação não-verbal humana parecem ser predominantemente inatos, outros principalmente aprendidos. Segundo Silva (1996), a comunicação não-verbal pode ser proveniente de pelo menos uma das seguintes fontes:

- Programas neurológicos herdados - próprios da espécie humana. Por exemplo, crianças surdas e cegas desde o nascimento apresentam as mesmas expressões de crianças normais (embora haja diferenças na intensidade das expressões);

- Experiências comuns a todos os membros da espécie - são as expressões relacionadas, principalmente, com a demonstração de necessidades fisiológicas. Por exemplo, independentemente da cultura, o bocejo significa sono, relaxamento; o movimento de mastigação é similar etc

- Experiências de acordo com a cultura, classe social e família - um exemplo de diferença cultural é aquela encontrada na expressão de emoções pelos japoneses e ingleses em comparação aos latinos: os primeiros são mais contidos para sorrir, chorar, demonstrar surpresa, apesar de essas emoções serem expressas na mesma zona facial em toda espécie humana. Esse aprendizado também é dado pela classe social a 
que pertencemos. Por exemplo, os sinais de refinamento sobre como se posicionar à mesa, o tom de voz a ser usado em cada ambiente e a postura ao sentar-se, são valorizados de forma diferente, de acordo com a classe social. E, por último, os códigos de família, os quais são entendidos por seus membros, permitindo que identifiquem com muita facilidade as emoções entre si.

Muitos movimentos expressivos humanos devem ter sido ritualizados, adquirindo função de sinais durante a evolução (Hinde, 1974). Entre eles podem ser citados o sorriso, a risada e o franzir das sobrancelhas, que encontram equivalentes homólogos em outros primatas ou mesmo outros mamíferos (Hinde, 1974 e Eibl-Eibesfeldt, 1989). Harris (1996) afirma que pesquisas recentes atribuem natureza inata (pelo menos) às expressões faciais de sofrimento, alegria e raiva. Por outro lado, vários sinais não-verbais que são usados no lugar de palavras, como o aceno significando "tchau", o balançar vertical da cabeça significando "sim" e o balançar horizontal da cabeça significando "não" parecem ser aprendidos no curso das interações sociais. Além disso, há formas de comunicação não-verbal que são idiossincráticas de uma ou mais pessoas, como é caso das saudações entre parceiros de um time esportivo ou os vários gestos utilizados por grupos de adolescentes. Estes rituais e práticas identificam o pertencimento ao grupo e fazem parte de sua identidade (Carvalho e Pedrosa, 2002). A comunicação não-verbal humana é evidente principalmente na primeira infância, quando as crianças ainda não possuem ou não dominam a linguagem.

\subsection{2- Comunicação na primeira infância}

Pode-se afirmar que os humanos começam a se comunicar desde o nascimento. $\mathrm{O}$ choro é a primeira manifestação vocal do recém-nascido e informa sobre suas necessidades e vontades. No início completamente involuntário, à medida que as estruturas corticais 
amadurecem, o choro passa a ser produzido voluntariamente e a ser utilizado para controlar o comportamento das pessoas que cuidam do bebê (Hauser, 1996). Posteriormente, por volta dos três meses, o bebê começa a produzir outras vocalizações, como grunhidos, gritos e risadas. Além disso, o recém-nascido já apresenta expressões faciais (por exemplo, Brannigan e Humphries, 1981; Eibl-Eibesfeldt, 1989; Field, 1989; Bergamasco e Beraldo, 1990), que indicam seu estado emocional e motivacional. É apenas por volta dos 12 meses que o bebê começa a produzir suas primeiras palavras, que são principalmente nomes para indivíduos específicos, objetos encontrados com freqüência e verbos de ação como "dar"e "ir" (Hauser, 1996). Aos 18 meses, a criança passa por uma importante transição, em seu desenvolvimento da linguagem, de palavras simples e um léxico limitado, para palavras combinadas e frases (Clark, 1993 apud Hauser, 1996).

Porém, a criança entra no mundo dos significados bem antes de adquirir e usar a linguagem (Pedrosa e Eckerman, 2000). Vários estudos têm sido realizados sobre o modo como crianças que ainda não aprenderam ou estão aprendendo a falar comunicam-se entre si e constroem, assim, conhecimento. Pedrosa e Eckerman (2000) observaram o comportamento de crianças de 6 a 18 meses, durante episódios de brincadeira livre, numa creche. As autoras afirmam que as crianças compartilham significados através de ações coletivas (disputa por objetos, ações articuladas, coordenação de ações, ações de consolo, imitação, alternância de papéis) que ocorrem quando elas interagem. A criança demonstra que conhece o significado de uma determinada situação quando regula seu comportamento de acordo com o de outra(s) criança(s); esta regulação pode ser unilateral ou recíproca, mas é sempre inerente a processos de interação social (Carvalho, Império-Hamburger e Pedrosa, 1998).

A partir da análise de interações sociais no decorrer da atividade lúdica de crianças pequenas, Carvalho, Império-Hamburger e Pedrosa formularam três princípios de sociabilidade: a orientação da atenção, o compartilhamento ou atribuição compartilhada 
de significados e a persistência de significados (Pedrosa e Carvalho, 1995; Carvalho, Império-Hamburger e Pedrosa, 1996 e 1998; Carvalho e Pedrosa, 2004 e Carvalho e Rubiano, 2004). A orientação da atenção pode ser definida como a direção do foco da atenção para a atividade ou presença de outro indivíduo, tornando possível o trânsito de informações do indivíduo observado ao indivíduo que observa. O compartilhamento ou atribuição compartilhada de significados ocorre quando dois ou mais indivíduos atribuem um mesmo significado a uma informação. O que denota o compartilhamento de significados é a ação conjunta e coordenada dos indivíduos. Já a persistência de significados configura-se quando um significado compartilhado permanece e se difunde dentro de um grupo social. O tempo de permanência não importa; ele pode durar poucos minutos ou passar a fazer parte da cultura de um grupo ou até de um povo. Não é a duração, e sim o fato da permanência, que conta (Carvalho, Império-Hamburger e Pedrosa, 1996). O primeiro princípio é requisito para o segundo, que é requisito para o terceiro. Através de sua formulação, as autoras procuram explicar como se dá a construção da comunicação num grupo de crianças pequenas, mas elas afirmam que os mesmos princípios também podem ser aplicados para compreender a comunicação em animais sociais não-humanos. No entanto, a persistência de significados requer capacidade de abstração e, portanto, não seria encontrada em todas as espécies sociais. É neste princípio que está contida a possibilidade de emergência ou diferenciação de um fenômeno especificamente humano: o símbolo e suas decorrências - a linguagem simbólica articulada e posteriormente grafada (Carvalho, Império-Hamburger e Pedrosa, 1996).

À medida que as capacidades comunicativas das crianças pequenas vão sendo desenvolvidas, seria esperado que a linguagem verbal - através, principalmente, da fala passasse a fazer parte, cada vez mais, das interações sociais infantis. No entanto, conforme Brannigan e Humphries (1981), embora crianças de 3 a 4 anos de idade utilizem a fala para se comunicar com adultos, elas ainda a usam com pouca freqüência durante brincadeiras de 
grupo, havendo uma predominância do emprego de gestos, expressões faciais e movimentos de intenção para coordenar suas atividades. Mesmo assim, alguns trabalhos (Carvalho, Império-Hamburger e Pedrosa, 1996; Carvalho e Pedrosa, 2004; Pedrosa e Carvalho, submetido) sugerem que crianças pequenas interagindo entre si emitem palavras não apenas num contexto e com uma referência usuais, mas também são capazes de usá-las com um sentido diferente do original.

\section{3- A criança como agente ativo de seu desenvolvimento: microcultura}

$\mathrm{O}$ enfoque atual da interação criança-criança no desenvolvimento infantil teve seu início no meio dos anos 70. Até esta época, os adultos eram considerados parceiros mais competentes e mais motivados para promover o desenvolvimento das crianças (Pedrosa e Carvalho, submetido). Tal visão pode ser explicada, em parte, pelo prevalecimento da concepção da criança como um ser incompetente, incompleto, passivo, desorganizado e moldável de forma a se tornar um adulto (Carvalho e Beraldo, 1989; Pedrosa e Carvalho, 1995). Também se pensava que as crianças não interagiam socialmente entre si e se aproximavam espontaneamente somente devido à presença de um objeto (brinquedo) que lhes despertasse um interesse comum. No entanto, diversos estudos mostraram que uma criança é atraída por outra muito mais freqüentemente do que por um adulto ou um objeto (Carvalho e Beraldo, 1989; Fiamenghi, 1999; Eckerman e Peterman, 2001). Carvalho e Beraldo (1989) classificam a interação criança-criança como uma "atividade de alta prioridade motivacional".

Trabalhos mais recentes têm revelado que a interação criança-criança exerce um papel fundamental no desenvolvimento comunicativo e social infantil (Carvalho e Beraldo, 1989; Pedrosa, 1989; Pedrosa e Carvalho, 1995; Carvalho, Império-Hamburger e Pedrosa, 1996 e 1998; Pedrosa e Eckerman, 2000; Eckerman e Peterman, 2001; Carvalho e Pedrosa, 2002; Carvalho e Pedrosa, 2004; Carvalho e Rubiano, 2004; Pedrosa e Carvalho, submetido). 
Através da interação com parceiros da mesma idade a criança vai formando suas primeiras relações sociais fora do contexto da família nuclear, ao mesmo tempo em que se constitui. Ou seja, a criança exerce um papel ativo em seu próprio desenvolvimento.

Além disso, há evidências de que se desenvolva uma espécie de cultura num grupo formado por crianças que se encontram regularmente. Tal cultura infantil (conhecida pelo nome "cultura de pares") foi definida por Corsaro (1997) como um conjunto estável de atividades ou rotinas, artefatos, valores e interesses que as crianças produzem e compartilham durante a interação com coetâneos. Carvalho e Pedrosa (2002) utilizam o termo microcultura ${ }^{3}$, neste mesmo sentido, com o intuito de investigar as formas de criação e de transformação de normas, maneiras de brincar, entre outros, no grupo social composto por crianças da mesma idade ou de idade próxima, num contexto de interação livre. Corsaro (op. cit.) propõe que se substitua o conceito de socialização em crianças pelo de "reprodução interpretativa". "Interpretativa" porque se refere aos aspectos criativos e inovadores da participação das crianças na sociedade e aponta para o fato de que as crianças criam e participam, em sua cultura de pares particular, a partir da apropriação criativa de informações do mundo adulto para lidar com suas próprias preocupações. E "reprodução" porque as crianças não internalizam, simplesmente, a sociedade e a cultura, mas estão contribuindo ativamente para a produção e mudança culturais. "O termo também implica que as crianças, pelo fato mesmo de sua participação na sociedade, são limitadas pela reprodução social. Ou seja, as crianças e suas infâncias são afetadas pelas sociedades e culturas das quais são membros.” (Pp. 298).

\footnotetext{
${ }^{3}$ Em oposição a macrocultura, que seriam os aspectos sócio-culturais, políticos e ideológicos mais gerais que caracterizam uma determinada sociedade.
} 


\section{2- OBJETIVOS}

Partindo das noções supracitadas e através da observação de crianças em interação livre em um grupo social estável, o trabalho visou, em primeiro lugar, a caracterização do processo social e cultural, identificando:

1) Como se manifesta a microcultura no grupo de crianças observado, por exemplo, em termos da importação de aspectos macroculturais para a brincadeira, de sua assimilação e da construção de aspectos particulares da microcultura do grupo;

2) Quais recursos comunicativos são utilizados nesse processo, por exemplo, se, mesmo antes de dominar a fala, as crianças emitem vocalizações num contexto e/ou com uma referencialidade convencionais; se as crianças criam palavras novas com contexto e/ou referencialidade específicos no grupo (construção de significados); se criam significados mediados não-verbalmente, através de ações e gestos; se utilizam palavras (ou gestos, ou ações) já presentes em seu repertório, com um sentido novo e próprio do grupo (reconstrução de significados);

3) Ocorrência de parcerias preferenciais entre as crianças e variação do modo predominante de brincadeira (solitário ou acompanhado) ao longo do período de observação;

4) Evidências da persistência de significados construídos no grupo, sob a forma de rotinas, jogos, modos de expressão, e papel da linguagem verbal nesse processo.

Em segundo lugar, procurou-se focalizar mais detalhadamente a transição do modo de comunicação exclusivamente não-verbal para o não-verbal e verbal integrados e suas possíveis transformações recíprocas, buscando pistas que mostrem: 
5) A viabilidade dos três princípios de sociabilidade (Pedrosa e Carvalho, 1995; Carvalho, Império-Hamburger e Pedrosa, 1996; Carvalho, Império-Hambuger e Pedrosa, 1998; Carvalho e Pedrosa, 2004; Carvalho e Rubiano, 2004) para explicar a emergência do modo verbal de comunicação;

6) Se, com o aumento da idade e à medida que a criança começa a falar, a comunicação nãoverbal deixa de ser tão evidente, sendo substituída cada vez mais pela fala, ou se continua a aparecer com frequiência na comunicação do grupo;

7) Quais as mudanças que a comunicação verbal ocasiona nas interações sociais entre crianças (por exemplo, negociar brincadeiras - Eckerman e Peterman, 2001); se e como o surgimento da fala influi na microcultura do grupo de crianças. 


\section{3- MÉTODO}

\section{1- A procura de uma creche adequada para a realização da pesquisa}

Foram visitadas quatro creches localizada na região Oeste da cidade de São Paulo. Destas, apenas uma foi escolhida, de acordo com os seguintes critérios: quantidade, idade (1 a 2 anos) e tipo de distribuição das crianças em grupos (manutenção da faixa etária requerida num mesmo grupo); espaço físico da creche; rotina de atividades (existência de períodos de atividade lúdica livre); recepção da pesquisa pela diretora e/ou coordenadora da creche (interesse, disponibilidade para fornecer informações) (Tabela 1).

Tabela 1 - Características das quatro creches visitadas $\left(1^{\circ}\right.$ Semestre de 2003).

\begin{tabular}{|c|c|c|c|c|c|c|}
\hline \multirow{2}{*}{ Creche } & \multicolumn{3}{|c|}{ Crianças } & \multirow{2}{*}{$\begin{array}{l}\text { Espaço } \\
\text { físico }\end{array}$} & \multirow{2}{*}{ Atividade livre } & \multirow{2}{*}{ Recepção } \\
\hline & Quantidade & Idade (1-2anos) & Distribuição & & & \\
\hline $\mathbf{A}$ & 32 & Sim & Por idade & Amplo & Pouca & Difícil \\
\hline B & $\begin{array}{c}\text { Sem } \\
\text { informação }\end{array}$ & Sem informação & Sem informação & Pequeno & $\begin{array}{c}\text { Sem } \\
\text { informação }\end{array}$ & Ausência \\
\hline $\mathbf{C}$ & Muitas & Sim & Por idade & Pequeno & Sim & Boa \\
\hline D & Nove $^{4}$ & Sim & $\begin{array}{c}\text { Por } \\
\text { desenvolvimento }\end{array}$ & Amplo & Sim & Ótima \\
\hline
\end{tabular}

A creche (A), é destinada aos professores e funcionários de uma Universidade e foi visitada em março e junho de 2003. Apesar de contar com um grande número de crianças de 1 a 2 anos de idade, ela não foi escolhida devido a: ter pouco tempo de atividade livre (havia muitas atividades dirigidas, como pintar, brincar de massinha, de teatro etc), que era realizada num pátio muito amplo (o que dificultaria a filmagem); separar as crianças de 1 e 2 anos em grupos diferentes que se encontravam apenas algumas vezes; e não ter havido muita disponibilidade da coordenadora e da psicóloga para obter respostas a solicitações.

\footnotetext{
${ }^{4}$ Porém, no da coleta de dados, o grupo contava com seis crianças, pois três foram transferidas para o grupo de crianças maiores.
} 
A creche (B), conveniada à Prefeitura, foi visitada em junho de 2003, porém, a diretora estava ausente, o espaço era pequeno e as crianças mais velhas tinham bastante contato com as mais novas, o que resultou na decisão de excluí-la como local de pesquisa. Já na creche $(\mathrm{C})$, também conveniada à Prefeitura, a coordenadora atendeu prontamente à pesquisadora, havia muitas crianças, no entanto elas estavam divididas por idade, em salas apertadas, onde passavam a maior parte do tempo, e havia um único espaço, um pátio restrito, onde as crianças podiam brincar livremente. Além disso, a coordenadora não demonstrou muito interesse pela pesquisa.

A creche (D), escolhida para a realização da pesquisa, foi a última a ser visitada (julho de 2003). É subsidiada pelo Governo Estadual e destinada aos filhos dos funcionários (a maioria de classe média e com nível de estudo superior) de um instituto de pesquisas. O que fez com que se decidisse por ela, foi: a boa recepção, a disponibilidade e o interesse demonstrado pela coordenadora e pela diretora; o espaço físico bem estruturado, com várias salas, um pátio, um solário e uma "praça" (área externa cercada por grades); a divisão das crianças em grupos de acordo com o critério de desenvolvimento (as crianças de 1 a 2 anos ficavam num mesmo grupo e estes eram mais estáveis, uma vez que sua composição não era determinada pela data de aniversário); e vários períodos de atividade lúdica livre. O único ponto desfavorável foi o número de crianças de 1 a 2 anos de idade (apenas nove), porém, a coordenadora indicou a possibilidade de outras crianças entrarem no grupo. Antes de iniciar a coleta de dados, solicitou-se aos pais que comparecessem à creche para uma reunião em que a doutoranda falou sobre sua pesquisa e pediu que eles assinassem um termo de consentimento (Apêndice 1) para que seus filhos pudessem participar dela. 


\section{2- Sujeitos e local de estudo}

Ao todo, participaram da pesquisa 10 crianças com 1 a 3 anos de idade. A escolha deste intervalo de idades se justifica por corresponder ao período em que as crianças estão, normalmente, começando a falar e também por já apresentarem autonomia de locomoção, o que lhes permite afastarem-se ou aproximarem-se com maior agilidade de outras crianças, de situações e de fatos de seu ambiente que lhes sejam aversivos ou atraentes (Pedrosa, 1989). Além disso, esta faixa etária tem sido extensivamente focalizada na literatura recente (Pedrosa, 1989; Corsaro, 1997; Eckerman e Peterman, 2001; Franchi e Vasconcelos, Amorim, Anjos e Rossetti Ferreira, no prelo), o que favorece análises comparativas.

O grupo de crianças focalizado apresentou algumas alterações ao longo do período de observação. Nas sessões realizadas de 14 de agosto a 13 de novembro de 2003, os sujeitos foram seis crianças, três meninos e três meninas, de 1 a 2 anos de idade que freqüentavam a creche desde os 4 meses, aproximadamente (com exceção de Alice, que ingressou na creche com 6 meses). Estas crianças foram as que fizeram parte do grupo do início ao fim da pesquisa (agosto de 2003 a dezembro de 2004; 17 meses). Em novembro, entrou mais uma menina no grupo, Meire, na época com 1 ano e 2 meses de idade, que permaneceu até maio de 2004. Em 2004 entraram: Gustavo (abril; 1a 1m), Bianca (agosto; 2a 8m) e Lia (outubro; 2a 9m). Todas as crianças ficavam na creche o dia inteiro (8 às 17h) e faziam parte do chamado “Grupo Lilás" (ou Intermediário). A Tabela 2 mostra os sujeitos e suas respectivas datas de nascimento e idades quando foram observados pela primeira e última vez. A idade inicial das crianças variou de 1 ano e 1 mês a 2 anos e 9 meses. As crianças mais novas eram Gustavo, Meire e Carlos e as crianças mais velhas Gisele, Heitor e Laura. 
Tabela 2 - Sujeitos ${ }^{5}$, suas datas de nascimento e idades na primeira e última sessão em que foram observados. OBS: Organização em ordem decrescente segundo a idade das crianças.

\begin{tabular}{|c|c|c|c|}
\hline \multirow{2}{*}{ Sujeitos } & \multirow{2}{*}{ Data de nascimento } & \multicolumn{2}{|c|}{ Idade $^{*}$} \\
\hline & & Início & Fim \\
\hline Gisele (Gi) & $10 / 10 / 01$ & $1 \mathrm{a} 10 \mathrm{~m}$ & $3 \mathrm{a} 2 \mathrm{~m}$ \\
\hline Heitor (H) & $18 / 10 / 01$ & $1 \mathrm{a} 9 \mathrm{~m}$ & $3 \mathrm{a} 1 \mathrm{~m}$ \\
\hline Laura (La) & $22 / 11 / 01$ & $1 \mathrm{a} 8 \mathrm{~m}$ & $3 \mathrm{a}$ \\
\hline Bianca (B) & $3 / 12 / 01$ & $2 \mathrm{a} 8 \mathrm{~m}^{1}$ & $2 \mathrm{a} 11 \mathrm{~m}^{\mathrm{V}}$ \\
\hline Lia (Li) & $13 / 1 / 02$ & 2a $9 \mathrm{~m}^{\mathrm{II}}$ & $2 \mathrm{a} 11 \mathrm{~m}$ \\
\hline Alice (A) & $7 / 2 / 02$ & $1 \mathrm{a} 6 \mathrm{~m}$ & $2 \mathrm{a} 10 \mathrm{~m}$ \\
\hline Sílvio (S) & $11 / 3 / 02$ & $1 \mathrm{a} 5 \mathrm{~m}$ & $2 \mathrm{a} 9 \mathrm{~m}$ \\
\hline Carlos (C) & $12 / 6 / 02$ & $1 \mathrm{a} 2 \mathrm{~m}$ & $2 \mathrm{a} 6 \mathrm{~m}$ \\
\hline Meire (M) & $5 / 9 / 02$ & $1 \mathrm{a} 2 \mathrm{~m}^{\mathrm{III}}$ & $1 \mathrm{a} 6 \mathrm{~m}^{\mathrm{VI}}$ \\
\hline Gustavo (Gu) & $28 / 2 / 03$ & $1 \mathrm{a} 1 \mathrm{~m}^{\mathrm{IV}}$ & 1a $9 \mathrm{~m}$ \\
\hline
\end{tabular}

- $\quad$ Data da primeira sessão: I = 25/8/04; II = 29/10/04; III = 20/11/03; IV = 22/4/04.

- Data da última sessão: $\mathrm{V}=2 / 12 / 04 ; \mathrm{VI}=28 / 4 / 04$.

As crianças eram acompanhadas, normalmente, por três educadoras: uma que ficava na creche em tempo integral, outra que ficava no período da manhã e outra no período da tarde.

As observações feitas em períodos de atividade lúdica livre das crianças (ver item 3.3) ocorreram em um dentre cinco espaços disponibilizados pela creche: duas salas internas, uma delas denominada "brinquedoteca" e outra "Sala do Lilás", e três espaços ao ar livre, um chamado "praça", outro "cimentado" e outro "solário". A brinquedoteca (5,7m X 5,2m) continha divisórias de madeira com "janela" e "porta" simulando duas casinhas sem telhado, de tamanho que possibilitava a entrada e o trânsito interno das crianças. Uma casinha parecia um quarto (com armário, roupas de boneca, berços e carrinhos de boneca), a outra uma cozinha (com geladeira, fogão, pia, panelinhas, mesa). Havia também vários brinquedos, como bonecas, animais de plástico, chapéus, bolsas e sapatos de adultos. Na praça existia gira-gira, balanços, escorregador, um tubo de cimento (do tipo de encanamento de esgoto) que

\footnotetext{
${ }^{5}$ Seus nomes foram alterados para resguardar suas identidades.
} 
formava um túnel, árvores frutíferas, além de uma caixa com brinquedos de plástico, como baldes e pás. O cimentado era um quintal amplo onde as crianças podiam correr e brincar; numa das extremidades havia uma casinha de madeira, com telhado, onde cabiam várias crianças e mesmo adultos. O solário era um terraço grande. Em geral, a seleção de um dos espaços era feita pelas educadoras e dependia do tempo (chuvoso e frio ou não) e do planejamento da creche. Até o mês de novembro de 2003, foram filmadas sete sessões de observação na praça, seis na brinquedoteca, duas no cimentado e uma no solário. Inicialmente, deu-se preferência à praça como local de filmagem (sendo solicitado que as crianças estivessem, se possível, na praça no dia da sessão), mas depois, considerou-se a brinquedoteca como um lugar mais adequado para ocorrerem as filmagens, pois nela as crianças podiam brincar com menor interferência das educadoras, além de seu uso não depender das condições climáticas. Portanto, a partir de dezembro de 2003 todas as sessões foram feitas na brinquedoteca. Contudo, no final de agosto de 2004 houve um remanejamento dos espaços da creche e o refeitório passou a ocupar o local onde antes funcionava a brinquedoteca, próximo à cozinha. Assim, tendo sido desativada a brinquedoteca, as filmagens passaram a ser realizadas na sala reservada ao grupo ("Sala do Lilás”), uma sala menor, com quatro conjuntos de mesinhas e cadeiras, um armário - onde eram guardados remédios, pastas de atividades das crianças, almofadas e outros objetos - duas estantes com alguns brinquedos e três colchonetes. Nessas salas, as crianças costumavam fazer atividades propostas pelas educadoras - como desenhar em seus cadernos, ouvir estórias ou músicas, brincar e jogar - mas também eram deixadas brincando livremente. O número de sessões feitas em cada espaço pode ser visto na Tabela 3. 
Tabela 3 - Freqüências absoluta e relativa do número de vezes que cada sessão de observação de atividade lúdica livre foi realizada em um dos cinco locais disponíveis na creche.

\begin{tabular}{l|c|c}
\hline Local da sessão & Freqüência absoluta & Freqüiência relativa (\%) \\
\hline Brinquedoteca & 32 & 60 \\
\hline Cimentado & 2 & 4 \\
\hline Praça & 7 & 13 \\
\hline Sala do Lilás & 11 & 21 \\
\hline Solário & 1 & 2 \\
\hline Total & 53 & 100 \\
\hline
\end{tabular}

As observações em situação semicontrolada (ver item 3.3) ocorreram numa sala onde as crianças normalmente dormiam após o almoço. Era uma sala ampla $(5,7 \mathrm{~m}$ X 5,9m), sem móveis ou outros objetos (a não ser alguns quadrinhos nas paredes), com cinco janelas em um dos lados, uma porta de correr, no lado oposto - por onde as crianças entravam - e uma segunda porta que dava acesso a uma pequena sala onde eram guardados os colchões e alguns brinquedos. Ela ficava na ala do berçário (ao lado dele), no andar superior da creche, sendo preponderantemente silenciosa.

\section{3- Procedimento}

De acordo com os objetivos do trabalho, a observação das crianças foi realizada em três situações:

$1^{\text {a }}$ situação) Em momentos de atividade lúdica livre (grupo todo): para possibilitar observações de interações mais espontâneas entre as crianças, sem a interferência de adultos. Solicitou-se às educadoras que interviessem o mínimo possível nas interações das crianças quando estas estivessem sendo filmadas. Assim, elas somente interagiam com as crianças quando havia necessidade (por exemplo, situações de perigo, brigas) ou quando as crianças lhes solicitavam atenção.O registro das interações sociais e da comunicação entre as crianças foi feito por meio de uma câmera de vídeo, em sessões semanais de observação, com duração de 30 a 60 minutos. 
O método de amostragem adotado foi o focal (conforme Altmann, 1974 e Setz, 1991). Ele foi escolhido por ser adequado à obtenção tanto de dados quantitativos quanto qualitativos. Cada criança (sujeito-focal) foi filmada durante 5 minutos, numa ordem aleatória pré-estabelecida para cada sessão. Porém, com a intenção de evitar a perda do registro de episódios de interação social e de comunicação em andamento, ao fim do intervalo de observação estipulado para cada sujeito, se a criança-focal estivesse interagindo com outra criança, o registro era realizado até o término da interação (caracterizado pelo afastamento entre as crianças, ausência de contato físico, vocal ou através do direcionamento do olhar ou outro tipo de interação social). O registro adicional ao intervalo de 5 minutos de observação foi considerado apenas em termos de análise qualitativa.

Algumas análises quantitativas foram feitas comparando-se dados do primeiro, segundo e terceiro semestre de observação, períodos que foram identificados, respectivamente, como Focais Iniciais, Focais Intermediários e Focais Finais.

Além disso, no início de cada sessão de observação era feita uma filmagem tipo varredura instantânea (scan-sampling; Altmann, 1974 e Setz, 1991) que, como foi apontado por Pedrosa (1989), fornece um pano de fundo para as análises posteriores. Este modelo de tomada visava explorar o ambiente ponto por ponto, mostrando a distribuição e as atividades das crianças no espaço, a localização das educadoras, a presença e a disposição de brinquedos etc. Sua duração era de, no máximo, 1 minuto. Nos dois primeiros meses de observação, a varredura era repetida na metade e no fim da sessão, porém, ao assistir a algumas sessões, percebeu-se que a varredura "intermediária” não era necessária.

A partir dos registros feitos pelo método de varredura instantânea, foram construídas matrizes de dupla-entrada, com o intuito de verificar a proximidade "intencional" das crianças entre si e delas em relação às educadoras. Consideraram-se "próximas" duas crianças que estavam a uma distância suficiente para interagirem sem terem que se locomover 
(aproximadamente 1m), excluindo-se as proximidades "acidentais", quando um indivíduo estava meramente passando perto de outro. Nas caselas das matrizes, estipulou-se a notação “1” para proximidade e "0” para não proximidade. Estes dados foram utilizados como indício da afinidade (ou preferência) social maior ou menor de uma criança em relação a outra, para a seleção das duplas participantes das "observações em situação semicontrolada" ( $2^{\mathrm{a}}$ a $6^{\mathrm{a}}$ fases $)$.

Houve uma modificação em relação ao plano inicial da pesquisa quanto à ênfase na análise qualitativa. Nas cinco primeiras sessões, com o auxílio de uma televisão e um vídeo cassete ou a própria câmera, cada focal de 5 minutos foi transcrito em intervalos de 30 segundos (10 intervalos por focal de 5 minutos), anotando-se as atividades do sujeito-focal, seus gestos, vocalizações, falas, risos, sorrisos, choros, expressões, direcionamento do olhar, bem como todas estas modalidades dirigidas por outra criança ou por uma educadora a ele. Adicionalmente, em cada intervalo foi feito um diagrama que mostrava a localização das crianças e das educadoras e sua movimentação no espaço. Contudo, esta forma de transcrição mostrou-se excessivamente detalhada e demorada, sendo utilizada apenas como base para análises posteriores (qualitativas e quantitativas) e para o estabelecimento de categorias comportamentais. Buscaram-se, então, métodos de análise mais objetivos, o que resultou em análises quantitativas, porém sem perder de vista a necessidade e a riqueza de analisar qualitativamente alguns episódios. Além disso, percebeu-se que uma análise quantitativa seria um diferencial a mais em relação a outras pesquisas da área e traria resultados mais significativos e esclarecedores. Assim, os dados obtidos a partir do registro de atividade lúdica livre foram analisados tanto de modo qualitativo quanto quantitativo. A análise qualitativa permite uma melhor descrição das observações e resulta num território fértil para discussões a respeito do tema de interações sociais. Devido ao grande montante de dados, apenas alguns episódios, mais interessantes e esclarecedores de acordo com a proposta do trabalho, foram escolhidos para serem analisados qualitativamente. 
Adicionalmente, a análise quantitativa foi aplicada no presente trabalho para verificar: a freqüência com que as crianças se comunicaram pelo modo verbal (fala) e não-verbal (gestos, expressões faciais, posturas, direcionamento da atenção, movimentos, vocalizações); se ocorreu alguma alteração da predominância de um ou outro tipo de comunicação à medida que elas foram crescendo; os tipos de brincadeiras registrados entre as crianças; e a persistência de significados construídos por elas durante suas interações diárias.

$2^{\text {a }}$ situação) Semicontrolada - duplas: a partir do segundo semestre de coleta, o registro em momentos de atividade lúdica livre das crianças foi intercalado com observações em uma situação semicontrolada. O planejamento inicial era realizar três rodadas destas sessões com todas as crianças - uma no início, outra em meados e outra no final do semestre. Porém, devido aos eventos observados terem sido bastante interessantes, decidiu-se continuar essas sessões no semestre seguinte, o que resultou em seis fases (rodadas) "experimentais". Deste modo, durante duas ou três semanas, ao invés de observar a atividade lúdica livre das crianças, foram feitas duas a três sessões no mesmo período (manhã ou tarde), durante dois ou três dias (dependendo do número de crianças), em situação semicontrolada. No projeto de pesquisa estava previsto que as crianças seriam divididas em grupinhos de três, pelo critério de maior proximidade de idade ou de afinidade social. Contudo, resolveu-se formar duplas entre as crianças, uma vez que havia menos de dez crianças no grupo todo. Eckerman, Davis e Didow (1989) e Eckerman e Didow (1996) utilizaram com sucesso a formação de duplas de crianças (16 a 32 meses de idade) a fim de registrar verbalizações e atos imitativos nãoverbais. Carvalho (1992) formou díades num grupo de crianças de 3 a 4 anos de idade para registrar episódios de interação durante a atividade lúdica.

Na primeira fase, todas as crianças foram pareadas para possibilitar comparações com os dados das rodadas seguintes; da segunda fase em diante, a formação de duplas seguiu o 
critério da afinidade social, considerando-se as matrizes de proximidade, obtidas a partir das amostragens por varredura, e o depoimento das educadoras. O critério de maior proximidade de idade, que constava no projeto, foi descartado, por não considerar as relações sociais e possíveis preferências entre as crianças. A duração das sessões era variável, dependendo da disposição das crianças, objetivando-se um mínimo de 10 minutos e idealmente 20 minutos para cada sessão, e registrando-se em vídeo e áudio as interações e brincadeiras das crianças. ${ }^{6}$ A finalidade deste procedimento é obter dados passíveis de categorização e análise quantitativa, com base nas propostas de Carvalho, Império-Hamburger e Pedrosa (1996 e 1998).

A seleção dos pares para a $1^{a}$ fase de duplas constituiu numa combinação sem repetição:

$$
\begin{aligned}
& C_{7}^{2}=\frac{7 !}{(7-2) ! 2 !} \\
& C_{7}^{2}=\frac{7.6 .5 !}{5 ! 2 !} \\
& C_{7}^{2}=\frac{7.6}{2.1}=21
\end{aligned}
$$

As 21 duplas de crianças foram ordenadas numa seqüência aleatória determinada através de sorteio. Como cada sessão estava prevista para durar no mínimo 10 e no máximo 20 minutos, foram realizadas três sessões por meio-período, totalizando sete meios-períodos ou três dias e meio de observações. De acordo com o planejamento da creche e a anuência da coordenadora, as observações foram feitas ao longo de duas semanas. A Tabela 4 mostra a organização das duplas em cada dia.

\footnotetext{
${ }^{6}$ Este procedimento tem sido utilizado por diversos autores, para maximizar a possibilidade de registro de verbalizações e obter dados passíveis de categorização e análise quantitativa (cf, por exemplo, Stambak e Verba, 1986; Carvalho, 1992; Pedrosa e Carvalho, 2002; Carvalho e Rubiano, 2004).
} 
Tabela 4 - Ordem de participação das duplas de crianças e semanas, dias e períodos em que foram observadas.

\begin{tabular}{|c|c|c|c|}
\hline Semana & Dia & Período & Dupla \\
\hline \multirow{9}{*}{1} & \multirow{3}{*}{1} & \multirow{3}{*}{ Manhã } & 1. Gisele - Sílvio \\
\hline & & & 2. Gisele - Heitor \\
\hline & & & 3. Heitor - Sílvio \\
\hline & \multirow{6}{*}{2} & \multirow{3}{*}{ Manhã } & 4. Alice - Sílvio \\
\hline & & & 5. Carlos - Heitor \\
\hline & & & 6. Alice - Meire \\
\hline & & \multirow{3}{*}{ Tarde } & 7. Carlos -Sílvio \\
\hline & & & 8. Laura - Sílvio \\
\hline & & & 9. Gisele - Laura \\
\hline \multirow{12}{*}{2} & \multirow{6}{*}{3} & \multirow{3}{*}{ Manhã } & 10. Heitor - Laura ${ }^{7}$ \\
\hline & & & 11. Alice - Gisele \\
\hline & & & 12. Meire - Sílvio \\
\hline & & \multirow{3}{*}{ Tarde } & 13. Heitor - Meire \\
\hline & & & 14. Alice - Laura \\
\hline & & & 15. Alice - Heitor \\
\hline & \multirow{6}{*}{4} & \multirow{3}{*}{ Manhã } & 16. Alice - Carlos \\
\hline & & & 17. Gisele - Meire \\
\hline & & & 18. Carlos - Gisele \\
\hline & & \multirow{3}{*}{ Tarde } & 19. Meire - Laura \\
\hline & & & 20. Carlos - Meire \\
\hline & & & 21. Carlos - Laura \\
\hline
\end{tabular}

A partir da observação da Tabela 4, pode-se notar que uma criança participou de duas sessões consecutivas no máximo duas vezes num mesmo período. Algumas hipóteses foram levantadas em relação à participação consecutiva de uma criança: 1) Ela poderia perder o interesse em brincar com os objetos disponíveis, pois já tinha tido contato com eles na sessão imediatamente anterior; 2) Tendo tido contato recente com os objetos, ela poderia tornar-se mais experiente (e talvez mais imitada) do que a outra criança; 3) Ela poderia ficar entediada de permanecer na sala por duas sessões consecutivas; 4) Como a outra criança da dupla era diferente nas duas sessões, ela poderia encontrar outros jeitos de brincar e outros interesses, não ficando entediada. A fim de diminuir os efeitos que a participação de uma criança em duas sessões consecutivas poderia ocasionar, procurou-se, sempre que possível, dar um 
intervalo mínimo de 5 minutos entre uma sessão e outra, quando as crianças saiam da sala, podendo ou não retornar ao local onde o grupo Lilás estava; a porta da "sala experimental" era fechada e a observadora verificava o estado dos objetos (efetuando reparos, se necessário) e os recolocava sobre a mesa. Na prática, algumas vezes o intervalo foi menor do que 5 minutos, porque, dependendo do lugar em que o grupo Lilás encontrava-se, a educadora não podia ficar muito tempo ausente do local, e, em geral, era uma das educadoras que levava as crianças até a "sala experimental" e que as buscava.

No início de cada período de observação, a pesquisadora colocava, sempre num mesmo ponto da sala, uma mesa $(80 \mathrm{~cm}$ X $80 \mathrm{~cm})$ e duas cadeiras em lados opostos da mesma, de tamanho adequado ao das crianças. Antes de cada sessão os objetos eram dispostos de maneira aleatória sobre a mesa; se as crianças mantivessem os objetos na mesma posição, antes da sessão seguinte a observadora rearranjava os objetos, alterando sua localização. Isto era feito para proporcionar uma chance igual dos objetos serem manipulados.

Foram selecionados 10 pares de objetos, cinco iguais e cinco diferentes, para serem disponibilizados às crianças (Apêndice 2). Três pares foram confeccionados pela observadora: dois tubos de papelão de papel higiênico pintados, um de amarelo com um Sol, representando o dia, e outro de azul com Lua e estrelas, representando a noite ${ }^{8}$; duas caixinhas de papelão quadradas pintadas com uma face de cada cor, preenchidas com pedrinhas de aquário e fechadas com cola e (depois que uma criança conseguiu abrir uma delas) com fita adesiva transparente, que faziam barulho ao serem chacoalhadas; duas mini garrafas de refrigerante (tipo PET) cheias com água, detergente, miçangas e lantejoulas em formato de estrelinha, que faziam espuma e um leve barulho ao serem sacudidas. Os outros objetos foram comprados.

\footnotetext{
${ }^{7}$ De acordo com o sorteio, esta dupla foi selecionada para participar após as duas duplas seguintes, mas teve que ser antecipada, pois Alice ainda não tinha chegado à creche e Sílvio estava no trocadouro de fralda com a educadora.

${ }^{8} \mathrm{Na}$ praça havia um tubo grande de concreto (tipo encanamento de esgoto) com uma pintura interna do dia, de um lado e da noite, de outro, e algumas crianças já tinham observado a diferença entre os dois.
} 
Os objetos foram escolhidos, em parte, com base em experimentos semelhantes realizados por outros autores e, em parte, de acordo com as observações dos objetos manipulados pelas crianças e que despertavam seu interesse nas sessões de atividade lúdica livre. Tubos de papelão foram utilizados por Lapierre e Lapierre (2002) e Pedrosa e Carvalho (2004).

Lapierre e Lapierre (op. cit.) também utilizaram bolas - "Leves, de plástico, em cores variadas e de diâmetro médio, esses objetos têm um dinamismo próprio, rolam, pulam, escapam; desse modo nós propomos a sua utilização nas primeiras sessões para facilitar o envolvimento das crianças." (Pp. 83) - e lenços (de cabeça) - "Com dimensões menores, também servem para esconder, cobrir, porém mais maleáveis do que os grandes tecidos. (...) Servem também para se vestir, para se "disfarçar" (...)." (Pp. 91-2). Durante as observações das crianças nos momentos de atividade lúdica livre, verificou-se o interesse de algumas por bolas e por panos, com o qual cobriam bonecas, e fantasias de pano (com formato de saco, com "orelhas" e buracos para os olhos); daí a idéia de colocar as bolas e os lenços entre os objetos da situação semicontrolada.

A inclusão das garrafas de refrigerante contendo água, detergente, miçangas e lantejoulas e das caixas de papelão coloridas com pedrinhas dentro, foi determinada pela curiosidade demonstrada pelas crianças em relação a objetos que fazem barulho, bem como pela presença de embalagens contendo água ou grãos de arroz no trabalho de Pedrosa e Carvalho (2004). As bolhas (resultantes do detergente na água), as miçangas e as lantejoulas das garrafas e o colorido das caixas foram pensados como artifícios que atraíssem a atenção visual das crianças.

Já os bonecos e as bolsas são exemplares que existiam, apesar de diferentes, na brinquedoteca, e com os quais as crianças brincavam bastante. Além disto, eles aparecem no trabalho feito por Carvalho (1992), embora este fosse com crianças maiores (3 a 4 anos). 
Finalmente, a escolha dos telefones e dos blocos de encaixar, seguiu o critério de interesse das crianças nos momentos de atividade lúdica livre, além de o telefone conter em si um significado relacionado à comunicação (todavia à distância) e dos blocos serem objetos que permitem construir algo, o que poderia favorecer o aparecimento de episódios de imitação entre as crianças.

Procurou-se garantir que todos os objetos fossem seguros para as crianças: a tinta, utilizada em alguns deles, foi do tipo guache atóxica; as “tampinhas” das bolas (pneumáticas) foram seladas com cola; as tampas das garrafas de refrigerante e das lanternas (compartimento das pilhas e das lâmpadas) foram vedadas com fita adesiva transparente; as caixas de papelão foram fechadas com cola e depois também com fita adesiva transparente. Os outros objetos não ofereciam perigo. Todos foram previamente mostrados à coordenadora da creche que concordou com sua utilização.

Da segunda fase em diante, as duplas foram selecionadas com base nos valores de proximidade obtidos pelo método de varredura e no julgamento das educadoras, já que elas tinham um contato diário com as crianças. A pergunta feita às educadoras, em separado, era: "Quais são as duas crianças que você acha que brincam mais juntas e quais as que você acha que brincam menos?".

Quanto aos objetos utilizados da $2^{\mathrm{a}}$ à $6^{\mathrm{a}}$ fase, foram selecionados cinco pares de objetos iguais e cinco de diferentes, como na $1^{\mathrm{a}}$ fase, tentando-se variar os objetos apresentados de uma fase a outra; apenas algumas repetições foram feitas (Apêndice 2). Ao todo, foram utilizados 24 pares de objetos iguais e 26 de diferentes, totalizando 50 pares de objetos ao longo das seis fases. A maior parte dos objetos foi escolhida porque se observou o interesse das crianças por objetos "tematicamente" semelhantes durante as sessões de observações em momentos de atividade lúdica livre. Outros, ainda, foram selecionados a partir de Lapierre e Lapierre (2002). 


\section{$3^{\text {a }}$ situação) Semicontrolada com todas as crianças ao mesmo tempo - sessões conjuntas:} foram planejadas com o objetivo de verificar se algum evento específico (brincadeira) criado em uma dupla apareceria novamente quando as crianças estivessem em grupo na mesma sala e com os mesmos tipos de objetos e também registrou-se quais seriam as parcerias preferenciais entre as crianças. Foram realizadas duas sessões de 20 minutos, com todas as crianças, num mesmo dia, duas semanas após o fim das sessões de duplas da $6^{\mathrm{a}}$ fase. Os métodos de registro utilizados foram o de "todas as ocorrências" (Altmann, 1974 e Setz, 1991) de brincadeiras, dando-se preferência a focalizar os grupinhos de crianças que se formassem, e scans (feitos no início e no fim de cada sessão conjunta). Os objetos disponíveis foram todos aqueles das seis fases (Apêndice 2), sendo que dez pares de objetos (cinco iguais e cinco diferentes) que se observou as crianças brincando mais foram duplicados (resultando em quatro exemplares do mesmo objeto): 1.i, 4.i, 8.i ${ }^{9}, 9 . i, 17 . i, 1 . d, 3 . d, 4 . d, 18 . d, 19 . d$ e 20.d.

Os dados quantitativos foram analisados aplicando-se o teste do $\chi^{2}$ (conforme Siegel, 1979) ou outros testes estatísticos adequados e com o auxílio do Programa SPSS 13.0 para o Windows.

Para maiores esclarecimentos sobre as sessões de observação de atividade lúdica livre e em situação semicontrolada, ver Apêndices 3 e 4.

\footnotetext{
${ }^{9}$ Como foi encontrado somente mais um exemplar do caminhão no comércio, disponibilizou-se apenas três unidades deste item.
} 


\section{4- RESULTADOS GERAIS}

\section{1- Observações em momentos de atividade lúdica livre}

As filmagens das crianças em momentos de atividade lúdica livre começaram, em 14/8/03 e se estenderam até 16/11/04. Foi realizada uma sessão semanal de filmagem ${ }^{10}$, com duração aproximada de 45 minutos cada, totalizando 53 sessões.

Durante o período de coleta de dados ocorreram algumas mudanças em relação ao grupo observado: entrada (novembro de 2003) e saída (abril de 2004) de Meire; entrada de três crianças (Gustavo, Bianca e Lia); saída de duas educadoras e entrada de uma nova; alteração do local onde eram realizadas as sessões (da brinquedoteca para a sala do Lilás). Estas mudanças não atrapalharam a pesquisa, embora seus efeitos não tenham sido verificados formalmente no comportamento das crianças.

Após cada sessão de observação eram feitas anotações sobre as crianças - sua saúde, comentários das educadoras, eventos interessantes que ocorreram durante a filmagem - com o intuito de auxiliar a análise posterior das fitas de vídeo.

\section{2- Observações em situação semicontrolada}

\subsection{1- Primeira fase de duplas}

A primeira rodada de observações em situação semicontrolada foi realizada em dois dias consecutivos na segunda e na terceira semana de março. Após os 10 minutos de duração

\footnotetext{
10 À exceção do mês de setembro de 2003- quando se deixou de filmar numa semana, pois o instituto onde se localiza a creche estava em greve, e realizaram-se duas sessões na semana seguinte (uma na segunda-feira e outra na sexta) - e nos meses de dezembro e janeiro, porque houve recesso da creche de 22/12/03 a 5/1/04 e a maioria das crianças do grupo Lilás voltou das férias na semana do dia 19/1.
} 
mínima estipulada para cada sessão, ela poderia ser terminada se as crianças não estivessem demonstrando interesse pelos objetos por 1 minuto, se pedissem para sair, se precisassem ir ao banheiro (algumas já estavam deixando a fralda) ou se chorassem. Ao final dos 20 minutos de duração máxima da sessão, a pesquisadora comunicava às crianças que estava na hora delas retornarem ao grupo. Se uma criança quisesse continuar a brincar, ela era informada de que voltaria à sala outras vezes para brincar com aqueles objetos.

Antes das crianças entrarem na sala, a única coisa que lhes era dito é que havia alguns objetos sobre a mesa para elas brincarem. A observadora permaneceu na sala para operar a câmera e auxiliar as crianças em alguma necessidade. Ela movimentava-se, silenciosamente, no espaço, de modo a capturar a imagem das duas crianças ao mesmo tempo, porém isto nem sempre era possível, devido ao tamanho da sala. A observadora somente interagia com as crianças se elas lhe perguntassem ou pedissem algo, se estivessem correndo algum risco de se machucar (como subir na janela ou bater com força no colega), machucassem-se efetivamente ou chorassem. Por conta desses fatores foi necessário interromper certas sessões, retomandoas em seguida.

De maneira geral, as crianças demonstraram grande interesse pelos objetos, maior, contudo, nas primeiras sessões em que participaram. A novidade estimula a curiosidade; portanto, o fato de cada criança ter participado seis vezes no total de uma condição em que estavam presentes os mesmos 10 pares de objetos deve ter sido um fator de desmotivação. $\mathrm{Na}$ segunda rodada de observações em situação semicontrolada em diante, o pareamento das crianças de acordo com preferências sociais diminuiu o número de vezes em que foram submetidas aos mesmos objetos. Outra idéia seria aumentar a variabilidade de exemplares disponíveis para as crianças brincarem, mas esta alteração não foi adotada, pois pareceu desnecessária, na prática. 
Apenas uma criança, Laura, mostrou-se pouco interessada pelos objetos em todas as sessões. Na primeira sessão subiu na janela; na segunda, jogou todos os objetos da mesa ao chão, duas vezes, e pediu para sair no minuto 15 da sessão. Na terceira, jogou os objetos no chão e pediu para sair antes dos 10 minutos (a observadora convenceu-a a ficar) e no minuto 16. Na quarta sessão, Laura pediu para sair, mais de uma vez, antes dos 10 minutos, jogou os objetos no chão, falando "eu não gosto" e chamou pela educadora. A observadora pediu (pelo interfone) para a educadora ir à sala, mas até que ela chegasse foi possível completar o intervalo mínimo de filmagem. Na quinta, chorou, tirou a calcinha (sua única peça de roupa no momento; a observadora solicitou que ela a recolocasse), pediu para sair. A observadora conseguiu mantê-la na sala até o minuto 10 da sessão, porém, logo depois, Laura pediu para ir ao banheiro e a sessão foi encerrada. Na última sessão, a observadora solicitou que uma das educadoras permanecesse na sala; foi a única vez em que Laura brincou mais com os objetos; contudo, a sessão foi terminada, após o intervalo mínimo, porque Laura queria ir ao banheiro. Nesta sessão a presença da educadora - mesmo ela tendo ficado pouco responsiva - interferiu bastante na interação entre as crianças, que requisitaram sua atenção diversas vezes. No entanto, é possível que Laura nem entrasse na sala se a educadora não estivesse lá. O comportamento de Laura foi analisado a fim de promover alterações no procedimento experimental que aumentassem o bem-estar das crianças - por exemplo, possibilitar que elas fossem ao banheiro ou bebessem água, quando necessário, e depois retornassem à sala, dando continuidade à sessão.

Todos os objetos disponíveis foram manipulados pelas crianças, mas à primeira vista, os que mais despertaram sua curiosidade foram as lanternas, as bolas, os telefones, os lenços e as mini garrafas. Foi interessante ver a interação das crianças com as lanternas; talvez elas nunca tivessem brincado com objetos assim. As lanternas eram dadas apagadas e apenas algumas crianças descobriram como acendê-las. Quando isto acontecia, ficavam admiradas 
com a luzinha que saia de dentro delas. Uma ou duas crianças foram observadas tentando acender uma lanterna apagada tocando a parte onde fica a lâmpada na mesma parte da outra lanterna acesa, como se a luz fosse fogo. As bolas também "fizeram sucesso", tendo como único inconveniente o fato de dispersarem bastante as crianças, uma vez que elas podiam se movimentar livremente pela sala. Os telefones foram mais usados para as crianças se comunicarem com pessoas ausentes ou imaginárias do que entre si. Os lenços eram fornecidos dobrados às crianças e suscitaram sua atenção a partir do momento em que elas perceberam que podiam abrí-los. Eles foram usados para: cobrir outros objetos, principalmente os bonecos; como lençóis ou toalhas de praia, sobre os quais as crianças sentavam-se ou deitavam-se; como pano de limpeza e como uma peça de roupa. As mini garrafas atraíram as crianças pela aparência visual e pelo som; também foram associadas com bebidas. Uma das crianças, Gisele (quando em dupla com Heitor), inventou uma brincadeira interessante utilizando uma bola e as garrafas (este episódio será analisado qualitativamente num item adiante). Ela virava uma garrafa e depois a outra, sobre a bola, falando "um poco de aia e um poco de ête" (um pouco de água e um pouco de leite/deste?) e chamando a atenção de Heitor para que ele entrasse na brincadeira. Então, jogava a bola, que parecia ter ganhado poderes mágicos, e ria, olhando para Heitor. Gisele repetiu o procedimento várias vezes. Heitor tentou imitá-la. Em sessões posteriores, Heitor foi visto tentando ensinar a brincadeira, inventada por Gisele, a outras crianças. Porém, talvez devido a ele quase não falar, seus gestos foram entendidos e copiados apenas por Carlos. Esta nova brincadeira, que surgiu na dupla entre Gisele e Heitor e que ele tentou passar para outras crianças, pode ser compreendida como uma evidência de persistência de significado e de microcultura. Além disso, este episódio evidencia a dificuldade de transmitir um conhecimento adquirido com uma criança para outra, quando a fala ainda não está estabelecida e a comunicação está limitada aos gestos e 
expressões não-verbais. Ou seja, extrapolando para uma escala mais ampla, a linguagem parece ser um facilitador muito potente da transmissão cultural.

Na maior parte das duplas, as crianças interagiram entre si. Muitas vezes desistiam de brincar com um objeto para brincar com o colega. Parecia que o legal era brincarem juntas. Foram observados vários episódios de imitação, que serão analisados numa seção posterior do trabalho.

\subsection{2- Segunda à sexta fase de duplas}

Dando continuidade às observações em situação semicontrolada foram realizadas mais cinco fases, espaçadas, em média, por 40 dias. O Apêndice 5 mostra os valores de proximidade que foram considerados para selecionar as duplas participantes da $2^{\mathrm{a}}$ à $6^{\mathrm{a}}$ fase. Embora esses valores não representem uma seqüência progressiva dos dados no tempo - pois uma parte dos resultados de proximidade adotados também foi usada como referência na fase anterior (ver nota no Apêndice 5)-, eles indicam que algumas relações foram mais freqüentes durante todo o período de coleta (principalmente $\mathrm{C}-\mathrm{H}$ ) e outras menos freqüentes (por exemplo, Gu-H, Gu-La, e Gu-S).

Quanto à opinião das educadoras, que também foi levada em conta para a seleção das díades, o Apêndice 6 mostra as duplas que elas julgaram brincar mais ou menos juntas em cada período que antecedeu uma rodada em situação semicontrolada. Buscou-se, sempre que possível, seguir a concordância entre suas opiniões. Pode-se verificar que apenas nas respostas da $4^{\mathrm{a}}$ fase não houve concordância entre as educadoras (e ainda houve uma contradição: C-S). De fato, nessa época as educadoras disseram que estava difícil apontar quais as duas crianças que brincavam mais ou menos juntas, pois todas estavam brigando bastante. Este comportamento mais agressivo das crianças foi atribuído à saída da educadora 
$E_{3}$ - que, segundo $E_{1}$, "azedou o grupo" - e à entrada de uma nova integrante no grupo $\left(\right.$ Bianca $\left.^{11}\right)$. Somente a educadora $E_{5}$ não manifestou dificuldade para responder.

A comparação dos dados contidos nos Apêndices 5 e 6 mostra que alguns valores de proximidade coincidem com o julgamento de pelo menos uma das educadoras: na $2^{\mathrm{a}}$ fase, AH (-) e Gi-La (+); na $3^{\text {a }}$ fase, A-La (-), C-H (+), C-S (+), Gi-La (+), tendo sido a fase com maior número de avaliações concordantes; na $4^{\mathrm{a}}$ fase não houve concordância; na $5^{\mathrm{a}}$ fase, BLa (-) e H-S (+); na $6^{\mathrm{a}}$ fase, Gi-La (-) e Gi-Li (-). Todos os pares que tiveram avaliações coincidentes foram selecionados para as observações em situação semicontrolada. Já as discordâncias entre valores de proximidade e julgamento das educadoras foram poucas: $\mathrm{Gu}-\mathrm{H}$ ( $3^{\mathrm{a}}$ fase), Gi-La ( $4^{\mathrm{a}}$ e $5^{\mathrm{a}}$ fases) e B-Li ( $6^{\mathrm{a}}$ fase). Mesmo que esses dados não correspondam a períodos exatamente iguais, pode-se concluir que houve mais concordância do que discordância entre os dois critérios utilizados para a formação de duplas. Carvalho e Rubiano (2004) analisaram vídeos contendo a filmagem de dois grupos de crianças com idade de 2 a 3 anos, em situação de atividade livre, em duas creches diferentes, e compararam as redes de relações obtidas por elas com base no indicador "compartilhamento de atividades", com outras redes obtidas, cada uma, a partir de outro critério: busca de contato social ou abordagem do parceiro; proximidade física; e relato das educadoras. As autoras concluíram que os diferentes indicadores evidenciaram redes sociais semelhantes.

Além disso, tomou-se o cuidado de balancear o número de vezes que cada criança participaria em cada fase, para evitar que ela se entediasse ou se tornasse mais experiente ou familiar com a situação experimental.

As duplas foram ordenadas tendo em mente evitar que uma mesma criança participasse de duas sessões seguidas e considerando as diferentes motivações das crianças para permanecerem na sala durante o tempo mínimo estipulado, no período da manhã ou da

\footnotetext{
${ }^{11}$ Bianca teve uma história familiar difícil e chegou à creche quase desnutrida, o que sensibilizou as educadoras, que lhe davam bastante atenção. Pode ser que as outras crianças tenham ficado enciumadas.
} 
tarde. Por exemplo, na $1^{\text {a }}$ fase de díades, observou-se que Laura parecia mais ansiosa à tarde, quando se aproximava o horário da chegada de sua mãe, portanto tentou-se evitar sua participação na última sessão da tarde; Heitor, como as outras crianças, dormia após o almoço, porém demorava um pouco mais para "acordar" realmente (ou seja, mostrar-se disposto para as atividades), assim as duplas foram planejadas de modo que ele não participasse da primeira sessão da tarde.

Pode-se verificar na Tabela 5 que, a partir da $2^{\mathrm{a}}$ fase, de 10 a 12 duplas participaram das sessões de observações em situação semicontrolada; que somente uma dupla $(\mathrm{C}-\mathrm{H})$ participou de todas as fases - e com alto índice de proximidade (Apêndice 5) - e que as duplas A-B e as quatro duplas das quais Lia fez parte ocorreram uma única vez (pois, ela entrou no grupo cerca de 1 mês antes da $6^{\mathrm{a}}$ fase). Onze duplas não foram feitas em nenhuma fase.

Tabela 5 - Semanas, dias e períodos de observações em situação semicontrolada e as duplas que participaram em cada um deles e em cada fase. Os sinais entre parênteses indicam maior (+) ou menor (-) proximidade, segundo a avaliação feita a partir dos scans e o julgamento das educadoras.

\begin{tabular}{|c|c|c|c|c|c|c|c|}
\hline \multirow{2}{*}{ Semana } & \multirow{2}{*}{ Dia } & \multirow{2}{*}{ Período } & \multicolumn{5}{|c|}{ Duplas } \\
\hline & & & $2^{\mathrm{a}}$ fase & $3^{\text {a }}$ fase & $4^{a}$ fase & $5^{\text {a }}$ fase $^{I X}$ & $6^{\text {a }}$ fase $^{X}$ \\
\hline \multirow{8}{*}{1} & \multirow{4}{*}{1} & \multirow{2}{*}{ Manhã } & & 1. C-H (+) & 1.Gi-H (+) & 1. B-Gu (+) & 1. A-La (+) \\
\hline & & & & 2. A-La (-) & 2. A-C (-) & 2. H-S (+) & 2. B-Gu (+) \\
\hline & & \multirow{2}{*}{ Tarde } & 1. A-S (+) & 3. Gu-Gi (-) & 3. La-S (-) & 3. A-La (+) & 3. Gi-Li (-) \\
\hline & & & 2. C-H (+) & 4. C-S (+) & 4. Gu-H (-) & 4. Gu-S (-) & 4. Gu-H (-) \\
\hline & \multirow{4}{*}{2} & \multirow{2}{*}{ Manhã } & 3. M-La (-) & & & & \\
\hline & & & 4. A-H (-) & & & & \\
\hline & & \multirow{2}{*}{ Tarde } & & 5. Gi-La (+) & 5. C-S $(+)^{\mathrm{VIII}}$ & 5. B-La (-) & 5. C-H (+) \\
\hline & & & & $\mathrm{V}$ & 6. Gi-La (-) & 6. Gu-H (+) & 6. B-Li (-) \\
\hline \multirow[t]{9}{*}{2} & \multirow{4}{*}{3} & \multirow{2}{*}{ Manhã } & 5. H-S (-) $)^{1}$ & 6. H-La (-) & 7. A-H (+) & & 7. La-S (-) \\
\hline & & & 6. Gi-La $(+)^{I I}$ & 7. A-C (- $)^{\mathrm{VI}}$ & 8. C-Gi (-) & & \\
\hline & & \multirow{2}{*}{ Tarde } & & 8. A-Gu (+) & 9. A-Gu (+) & 7. C-Gi (-) & 8. Gu-Gi (+) \\
\hline & & & & 9. C-Gi (+) $)^{\mathrm{VII}}$ & 10. $\mathrm{C}-\mathrm{H}(+)$ & 8. La-S (-) & 9. A-Li (+) \\
\hline & \multirow{5}{*}{4} & \multirow{2}{*}{ Manhã } & 7. A-La (-) $)^{\mathrm{III}}$ & & & & \\
\hline & & & & & & & \\
\hline & & \multirow{3}{*}{ Tarde } & & 10. A-H (+) & & 9. A-Gi (+) & 10. C-Li (-) \\
\hline & & & & 11. Gu-H (-) & & 10. C-H (+) & 11. A-B (-) \\
\hline & & & & & & & 12. C-S (+) \\
\hline
\end{tabular}




\begin{tabular}{|c|c|c|c|c|c|c|c|}
\hline \multirow{6}{*}{ Semana } & \multirow{2}{*}{ Dia } & \multirow{2}{*}{ Período } & \multicolumn{5}{|c|}{ Duplas } \\
\hline & & & $2^{a}$ fase & $3^{a}$ fase & $4^{a}$ fase & $5^{a}$ fase $^{I X}$ & $6^{a}$ fase $^{X}$ \\
\hline & \multirow{4}{*}{5} & Manhã & & & & & \\
\hline & & \multirow{3}{*}{ Tarde } & $8 \mathrm{C}_{-} \mathrm{Gi}_{(+1} \mathrm{IV}$ & & & & \\
\hline & & & 8. C-G1 (+) & & & & \\
\hline & & & 10. C-S (+) & & & & \\
\hline \multirow{4}{*}{3} & \multirow{4}{*}{6} & \multirow{2}{*}{ Manhã } & & & & & \\
\hline & & & & & & & \\
\hline & & \multirow{2}{*}{ Tarde } & & & & 11. Gi-H (+) & \\
\hline & & & & & & & \\
\hline
\end{tabular}

Nota: I) A dupla planejada era C-Gi, mas C faltou (doente); II) A dupla planejada era M-S, porém M foi viajar; III) Substituição de M-S; IV) Esta dupla era para ser feita na manhã do dia 4, contudo, C faltou (doente); V) Era para ter sido a dupla A-C, porém A saiu mais cedo da creche; VI) A dupla planejada era A-S, no entanto S ficou afastado da creche (viagem) durante 10 dias; VII) Esta dupla não estava planejada e foi realizada porque C perguntou por Gi várias vezes, quando com outras crianças; VIII) Esta dupla era para ser a segunda da tarde (e Gi-La a primeira), porém foi feita antes pois C ia embora mais cedo da creche; IX) Ocorreram várias modificações em relação ao planejamento das duplas da $5^{\text {a }}$ fase, uma vez que $\mathrm{C}$ faltou no dia 1 , Gi faltou durante toda a semana 1 e B foi viajar a partir do dia 3, sem data para retorno. Assim, a ordem das duplas foi modificada e a dupla A-B foi excluída. X) Houve alterações na ordem das duplas 3, 4, 5, 8, 9 e 10, porque no dia $1 \mathrm{C}$ faltou, e no dia 3 B e S estavam fazendo "adaptação" no grupo dos maiores. A dupla B-Li não estava programada, porém pareceu interessante sua ocorrência, pois as duas tinham entrado no grupo há pouco tempo.

Em termos do que foi observado nas sessões, os objetos com os quais as crianças mais brincaram foram: barris (1.i, curiosidade para saber o que tinha dentro, desafio de como abrir e depois fechar, quando abertos pareciam potinhos; principalmente as meninas); bolas (2.i, principalmente os meninos); bonecos (4.i e 5.i); carrinhos (8.i, 9.i, 24.d); caixas de papelão (7.i, caminhão, cavalo, cama, casa, berço para bonecos Tikinho); colares (10.i); garrafas pet (13.i); kits médicos (14.i); módulos geométricos (16.i, desencaixar e encaixar peças nos pinos); molas de plástico (17.i); peças de madeira (18.i); telefones (23.i); bambolês (1.d); bóias de cintura (4.d, fizeram de berço para os bonecos Tikinho, de almofada para se sentarem e andaram com elas na cintura, no pescoço e nos pés); tecidos (8.d, brincaram de praia, piscina, camas para os bonecos Tikinho; principalmente as meninas, e 19.d, para cobrir outros objetos, como lençóis, toalhas de praia, pano de limpeza, vestimenta); casinhas de plástico (13.d, colocar peças nos orifícios corretos e retirá-las da casinha, colocar outros objetos dentro da casinha; isto também ocorreu com as vans, 9.i); fantoches (14.d, apertar o bico para ouvir o som da buzina e ver a língua de sogra se desenrolar, separar o bico da roupa e brincar somente 
com o primeiro); lanternas (18.d, acender, apagar, iluminar os objetos, o ambiente e a si próprios); e óculos (20.d).

É importante ressaltar alguns pontos sobre as observações em situação semicontrolada. Ao longo das diferentes fases, ficaram evidentes o desenvolvimento da fala das crianças, que adquiriu maior clareza, e o aumento da complexidade das brincadeiras, com o fantasiar cada vez mais presente. Além disso, as crianças parecem ter adquirido maior confiança e segurança em relação a ficarem na sala sozinhas com a pesquisadora. Também, o fato de poderem brincar sem muita intervenção - a não ser quando a situação oferecesse perigo para elas também deve ter sido motivador para a participação das crianças.

Devido ao grande interesse demonstrado pelas crianças, ao longo da $5^{\text {a }}$ fase de duplas surgiu a idéia de fazer uma ou mais sessões de observações em situação semicontrolada com todas as crianças ao mesmo tempo e verificar se algum evento específico (brincadeira) criado em uma dupla apareceria novamente, se ele seria transmitido para outras crianças do grupo, se ocorreriam eventos novos (brincadeiras novas) e quais seriam as parcerias preferenciais entre as crianças naquela situação, pois elas estavam livres para escolher com quem queriam ficar e não mais separadas em duplas. Tentou-se, assim, obter mais dados a respeito de microcultura no grupo estudado. Desse modo, foram realizadas duas sessões - que foram denominadas "sessões conjuntas" (item 3.3) - de 20 minutos, com todas as crianças, num mesmo dia, duas semanas após o fim das sessões de duplas da $6^{\mathrm{a}}$ fase.

O Apêndice 4 mostra quando foi realizado cada tipo de forma de observação atividade lúdica livre e situação semicontrolada ( $1^{\mathrm{a}}$ à $6^{\mathrm{a}}$ fase e sessões conjuntas $)$ - durante o período de coleta de dados.

Por fim, é importante destacar a cooperação das educadoras, da coordenadora e mesmo de outros funcionários da creche para o bom andamento das observações em situação semicontrolada. As crianças nem sempre estavam no mesmo andar da "sala experimental", 
onde ficava a brinquedoteca e o solário, sendo necessário subir e descer escadas para ir de um local ao outro. As educadoras não se importaram em fazer isto mais de uma vez por período. A funcionária que ficava no berçário também ajudou, permanecendo algumas vezes com as crianças durante a troca de duplas (intervalo entre as sessões). A equipe da creche foi bem flexível, também, quanto ao horário disponível para serem realizadas as sessões de observação, estendendo-o um pouco, se fosse necessário. Essas atitudes e todas as experiências tidas com a creche mais do que legitimam a sua escolha em detrimento das outras, com maior número de crianças, porém com uma estrutura física e organizacional menos adequadas para a realização da pesquisa. 


\section{5- ANÁLISE DOS DADOS}

Os dados obtidos a partir das filmagens das crianças foram analisados quanto à: freqüência de comunicação verbal e não-verbal; orientação da atenção; persistência de significados; tipos de brincadeiras; e a imitação.

\section{1- Análise da freqüência de comunicação verbal e não-verbal, no começo e no final do primeiro semestre}

Esta foi a primeira tentativa de categorização do comportamento comunicativo e social das crianças. Consistiu em analisar os cinco primeiros e os cinco últimos focais de cada criança (60 focais ou 300 minutos no total) - obtidos no período de agosto a dezembro de 2003 - de acordo com 14 categorias: sete referentes à interação dirigida pelo sujeito-focal a outra criança ou a um adulto (educadora ou pesquisadora) e sete referentes à interação dirigida ao sujeito-focal por outra criança ou um adulto (Tabela 6 e Figuras 1 a 5).

Tal classificação foi criada a partir das categorias comportamentais analisadas por Eckerman et al. (1989) e Eckerman e Didow (1996). Porém, a sua utilização na prática,

mostrou-se bastante trabalhosa e demorada e os resultados obtidos foram pouco esclarecedores. A análise das fitas foi feita com o auxílio do programa EthoLog 2.2 (Ottoni, 2000), que foi desenvolvido especificamente para a transcrição de sessões de observação de comportamento. 
Tabela 6 - Categorias comportamentais utilizadas para registrar os modos de comunicação verbal e não-verbal de três meninos $(\mathrm{C}, \mathrm{H}$ e $\mathrm{S})$ e três meninas (A, Gi e La) com idades entre 14 e 26 meses.

\begin{tabular}{|c|c|c|c|}
\hline \multicolumn{2}{|c|}{ Categoria } & Sigla & Descrição \\
\hline \multirow{12}{*}{ 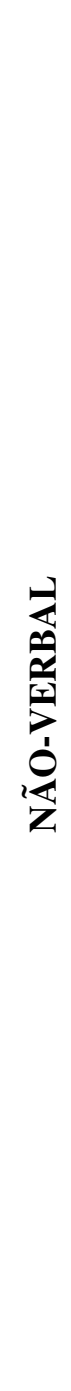 } & \multirow{2}{*}{ } & A & Manifestar atenção (olhar, observar; sujeito-focal em relação a outro indivíduo). \\
\hline & & $\mathbf{a}$ & Receber atenção (atenção de um outro indivíduo em relação ao focal). \\
\hline & \multirow{2}{*}{ 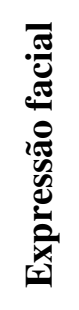 } & $\mathbf{E}$ & $\begin{array}{l}\text { Exibir expressão facial (sorriso fechado }=\text { sem mostrar os dentes; sorriso aberto = } \\
\text { mostrando os dentes; riso; choro; surpresa; raiva; medo...). }\end{array}$ \\
\hline & & $\mathbf{e}$ & Receber expressão facial (de um outro indivíduo em relação ao focal). \\
\hline & \multirow{2}{*}{ 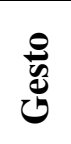 } & $\mathbf{G}$ & Fazer gesto (acenar, apontar, bater no assento etc). \\
\hline & & g & Receber gesto (de outro indivíduo em relação ao focal). \\
\hline & \multirow{2}{*}{ 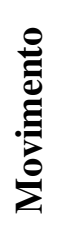 } & M & $\begin{array}{l}\text { Fazer movimento (andar em direção a, bater, empurrar, puxar, afastar... Pode incluir } \\
\text { imitação). }\end{array}$ \\
\hline & & $\mathbf{m}$ & Receber movimento (outro indivíduo em relação ao focal). \\
\hline & \multirow{2}{*}{ 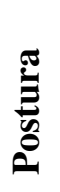 } & $\mathbf{P}$ & $\begin{array}{l}\text { Exibir alteração de postura (abaixar, levantar, inclinar-se, virar a cabeça e/ou corpo para } \\
\text { olhar para alguém). }\end{array}$ \\
\hline & & $\mathbf{p}$ & Receber alteração de postura (de outro indivíduo em relação ao focal). \\
\hline & \multirow[b]{2}{*}{ 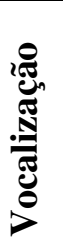 } & VO & Emitir vocalização (interjeições, letras, sílabas). \\
\hline & & vo & Receber vocalização (vocalização emitida por outro indivíduo, mas endereçada ao focal). \\
\hline \multirow[b]{2}{*}{$\frac{2}{2}$} & \multirow{2}{*}{ 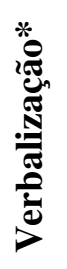 } & $\mathbf{V E}$ & Emitir verbalização (palavra ou frase falada). \\
\hline & & ve & $\begin{array}{l}\text { Receber verbalização (verbalização emitida por outro indivíduo, mas endereçada ao } \\
\text { focal). }\end{array}$ \\
\hline
\end{tabular}




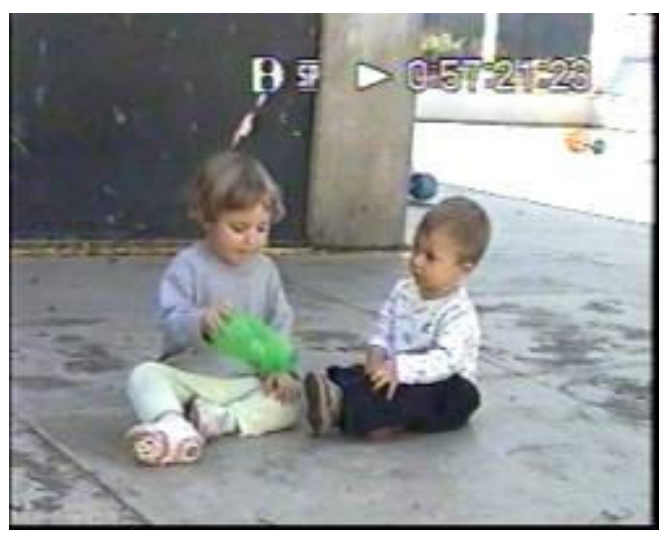

Figura 1 - Atenção: Sílvio observando Gisele bater embalagem de xampu no chão.

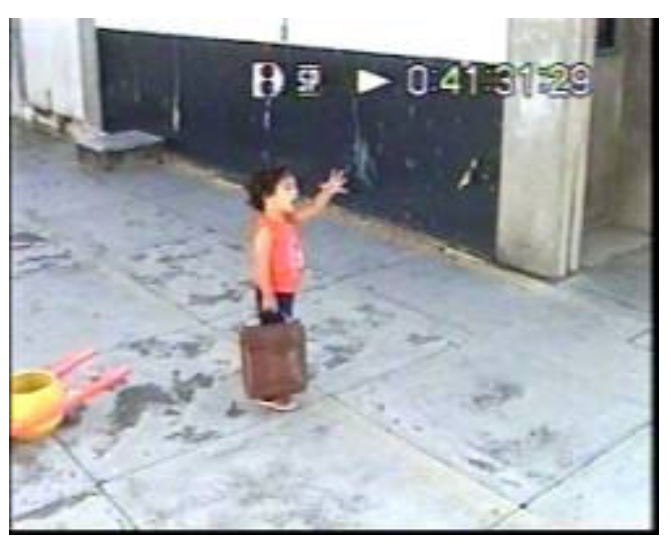

Figura 3 - Gesto: Laura acenando (tchau) - para educadora.

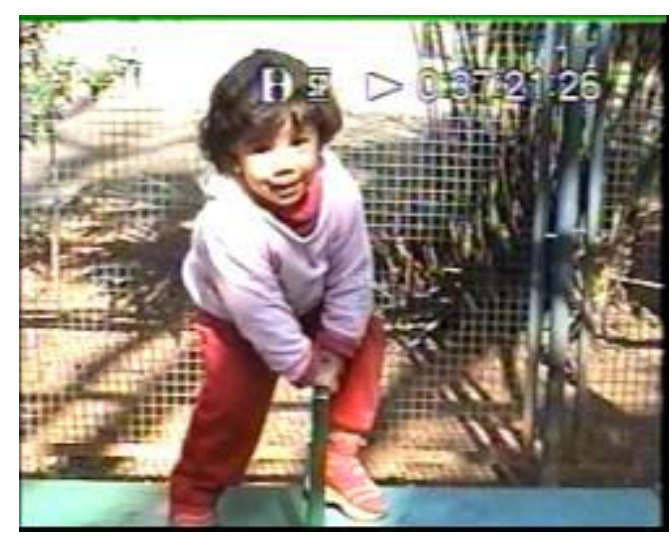

Figura 2 - Expressão facial: Laura emitindo sorriso aberto para a câmera (pesquisadora).

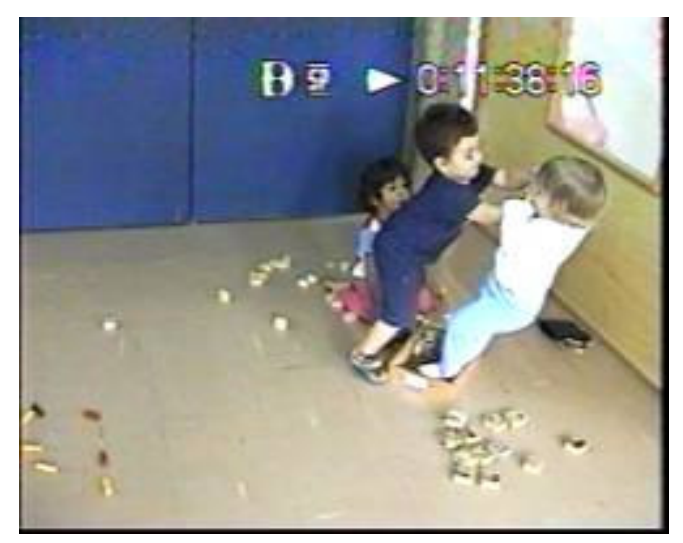

Figura 4 - Movimento: Carlos empurrando Gisele.

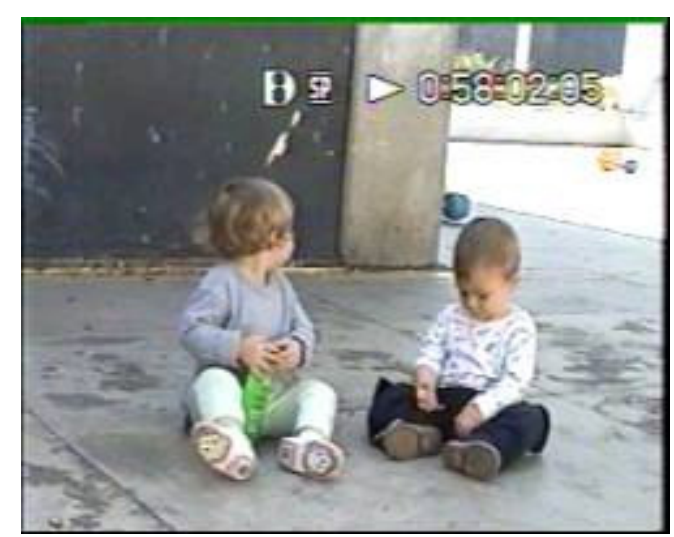

Figura 5 - Postura: Gisele vira cabeça e corpo para olhar educadora ao longe. 


\section{Resultados}

O número total de eventos comunicativos registrados no período inicial foi igual a 999 e, no período final, 959. A análise da frequiência de comunicação verbal e não-verbal segundo as categorias estabelecidas (Tabela 6) mostrou que atenção e movimento foram os modos de comunicação utilizados mais freqüentemente pelas crianças, nos dois períodos (cinco primeiros e cinco últimos focais), enquanto gesto foi o menos freqüente. (Figura 6).

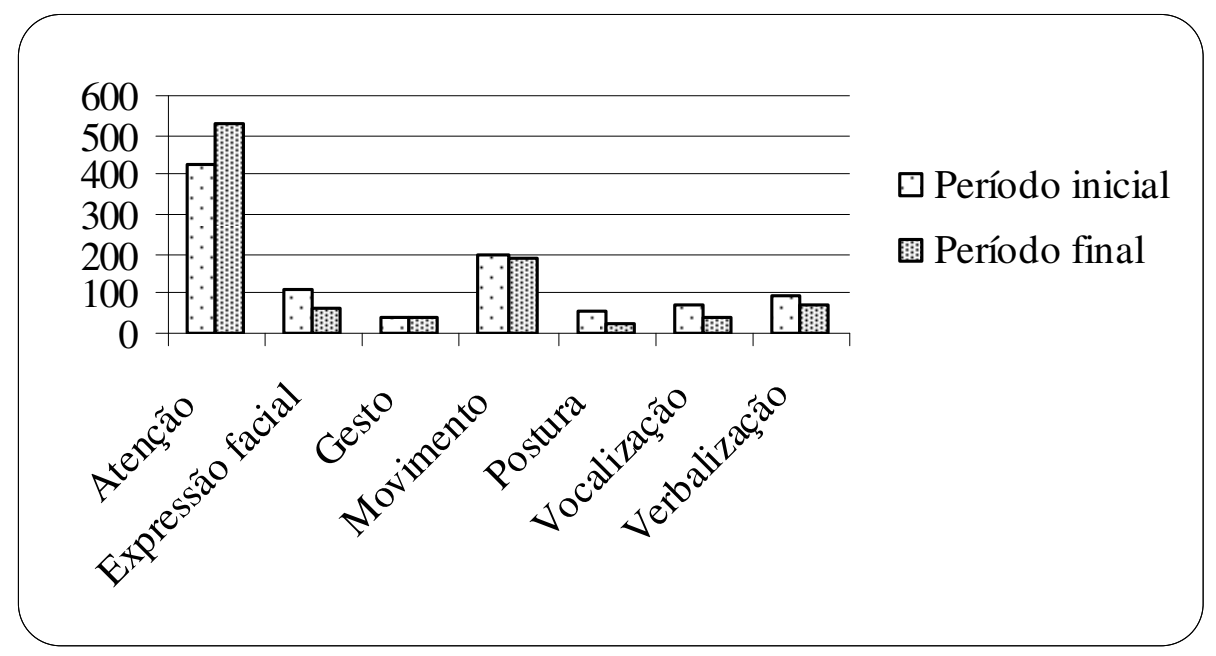

Figura 6 - Total do número de eventos (soma dos eventos apresentados por todas as crianças) registrados para cada categoria, nos períodos inicial e final de observação.

A análise estatística dos dados mostrou que houve diferença significativa entre os valores obtidos nos períodos inicial e final para atenção $\left(\chi^{2}=23,38 ; \mathrm{p}=0\right)$, expressão facial $\left(\chi^{2}=13,45 ; \mathrm{p}=0,0002\right)$ e postura $\left(\chi^{2}=8,65 ; \mathrm{p}=0,0033\right)$. Ou seja, as crianças se comunicaram mais pela atenção, porém menos por expressões faciais e alterações de postura, no período final do que no inicial.

A Figura 7 evidencia que o total de comunicação não-verbal (soma das categorias) prevalece em relação ao de comunicação verbal nos dois períodos. 


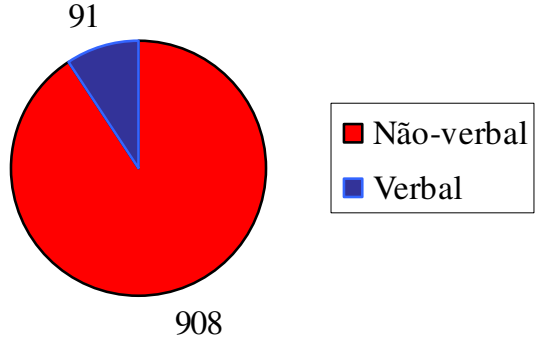

Período inicial

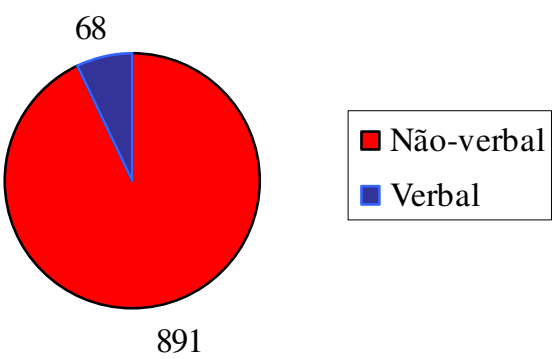

Período final

Figura 7 - Comparação entre o número de eventos de comunicação verbal e não-verbal nos períodos inicial e final de observações.

Verificou-se que a categoria atenção correspondeu a 47\% dos eventos de comunicação não-verbal no período inicial e a $59 \%$ no período final. Considerando que a orientação da atenção precede as interações sociais, esta categoria foi interpretada ${ }^{12}$ como tendo apenas valor comunicativo potencial e, portanto, seus valores foram subtraídos do total de comunicação não-verbal de ambos os períodos. Assim, a diminuição da freqüência de comunicação não-verbal do período inicial para o final foi significativa (ANOVA: F = 5,69; df $=1 ; p=0,04)$. A média dos valores de comunicação não-verbal foi $80,00(\mathrm{SD}=19,99)$ no primeiro período e $60,50(\mathrm{SD}=17,77)$ no segundo.

A análise da comunicação não-verbal (excluindo atenção) para cada criança mostrou valores menores durante o último período (em relação ao primeiro) para todas as crianças, exceto Sílvio (Figura 8).

\footnotetext{
${ }^{12}$ Esta interpretação não foi mantida num momento posterior do trabalho, pois ao refletir-se melhor sobre a questão, concluiu-se que atenção faz parte da comunicação, sim.
} 


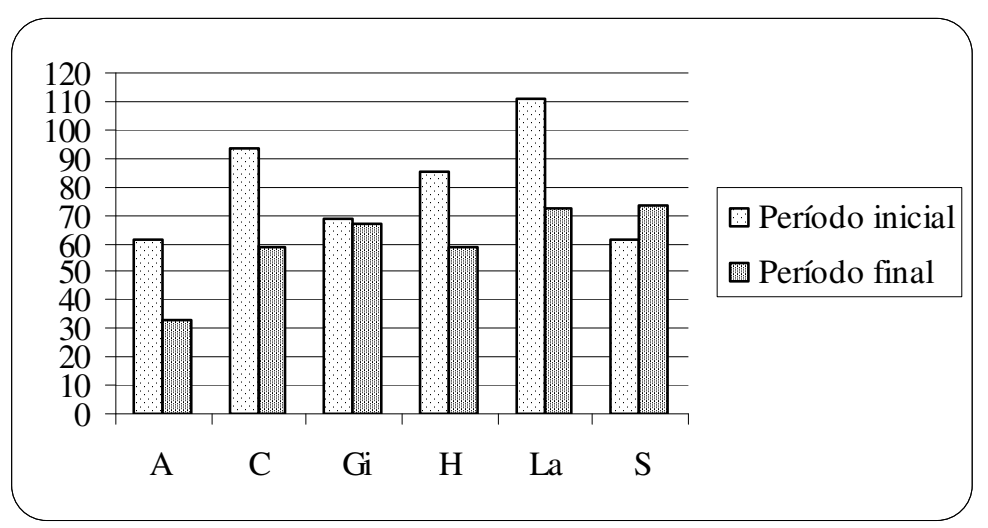

Figura 8 - Comparação da freqüência absoluta de comunicação não-verbal (excluindo os valores de atenção) no período de observação inicial e no final para cada criança (A, C, Gi, H, La e S).

Resultados semelhantes foram obtidos para a comunicação verbal, que aumentou apenas para Heitor e Sílvio (Figura 9). Gisele foi a criança que falou mais, nos dois períodos, seguida por Alice (período inicial) e Laura (período final). Heitor foi a criança que falou menos, no período inicial, seguido por Carlos e Sílvio. Já no período final, Carlos foi a criança que falou menos, seguido por Heitor e Alice. Estes resultados podem ser atribuídos à idade das crianças: Gisele e Laura eram as crianças mais velhas do grupo; Heitor, apesar de ter mais ou menos a mesma idade delas, apresentava um atraso no desenvolvimento da fala; e Carlos e Sílvio eram as crianças mais novas.

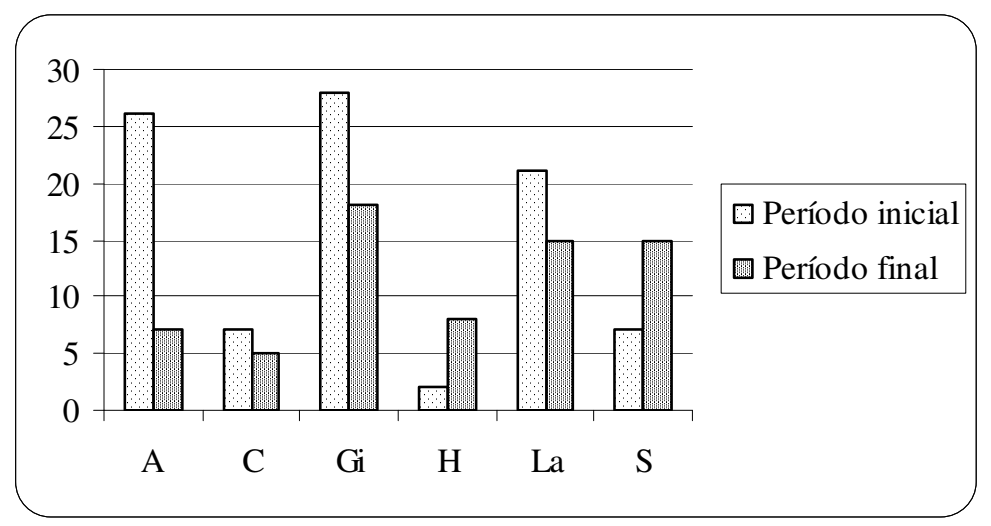

Figura 9 - Comparação da freqüência absoluta de comunicação verbal nos períodos de observação inicial e final para cada criança (A, C, Gi, H, La e S). 
Finalmente, foi aplicado um teste para verificar se havia correlação entre as freqüências de emissão e recepção de cada uma das categorias de comunicação. Houve correlação apenas para atenção (Spearman's rho =0,829; $\mathrm{p}=0,042 ; \mathrm{N}=6$ ).

A partir dos resultados citados, pode-se concluir que, embora tenha havido uma redução significativa no número de eventos de comunicação não-verbal (principalmente quando atenção é excluída), ela não foi acompanhada por um aumento equivalente nos eventos de comunicação verbal. Uma explicação plausível é que o intervalo entre os períodos inicial e final analisados não tenha sido suficientemente grande para avaliar diferenças quantitativas entre esses dois tipos de comunicação. Por outro lado, é possível que quanto maior o tempo de convivência (e interação) de indivíduos num grupo, mais abreviados tornem-se os sinais comunicativos. Portanto, a diminuição da frequiência de eventos comunicativos não-verbais entre as crianças, considerando que esta era ainda sua principal via de comunicação, pode estar associada ao uso de "canais comunicativos" mais sutis, que não puderam ser detectados pelas categorias comportamentais estabelecidas.

\section{2- Orientação da atenção e afinidade social}

Com base nos resultados da forma de análise anterior, procurou-se outras maneiras de classificar o comportamento interativo das crianças. As primeiras providências foram eliminar, da análise, a interação entre adulto (educadora ou pesquisadora) e criança e diminuir o número de categorias. Além disso, categorias como "atenção" e "movimento" mostraram-se pouco precisas. Entendendo-se que a orientação da atenção para algo ou, principalmente, alguém é o primeiro passo para que ocorra interação social, e que ela constitui um ato comunicativo em si - assim como o é ignorar propositalmente o outro - buscou-se desenvolver categorias atencionais. 
"Orientação da atenção" consiste no primeiro dos três princípios de sociabilidade elaborados por Carvalho, Império-Hamburger e Pedrosa (Pedrosa e Carvalho, 1995; Carvalho, Império-Hamburger e Pedrosa, 1996 e 1998; Carvalho e Pedrosa, 2004 e Carvalho e Rubiano, 2004). Eckerman e Didow (1996) consideram a atenção visual de uma criança para o seu par, em seus estudos sobre ação coordenada. Já Tomasello (2003) destaca os comportamentos chamados de "atenção conjunta" (joint attention), que se desenvolvem nas crianças por volta dos 9 aos 12 meses de idade, como sendo essenciais para que ocorra imitação e aprendizagem cultural. Em geral, o termo atenção conjunta é definido para descrever as relações que ocorrem entre uma criança e um adulto que focalizam um mesmo objeto ou evento do ambiente. Consiste numa interação triádica, pois envolve uma criança, um adulto e uma entidade externa a ambos. Seria interessante verificar, então, se e como isto ocorre entre crianças (sem a participação do adulto). Partindo dos autores supracitados, foram formuladas as seguintes categorias para serem aplicadas à análise das sessões de duplas (observações em situação semicontrolada):

AC - Atenção conjunta (ou compartilhada): as duas crianças olham (dirigem sua atenção) para um mesmo aspecto do ambiente.

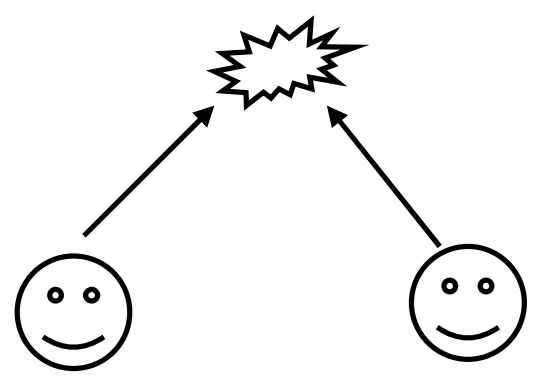

AU - Atenção unilateral: uma criança olha para a outra e esta não está olhando para a primeira.

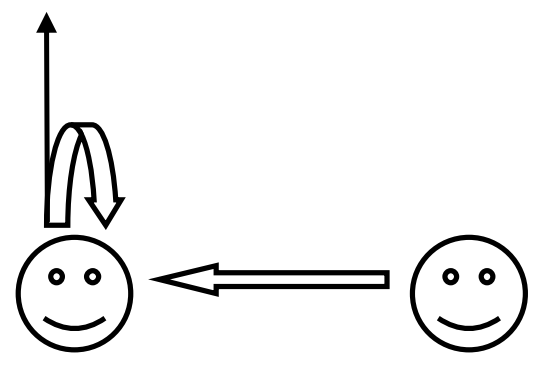


AR - Atenção recíproca: uma criança olha para a outra e vice-versa.

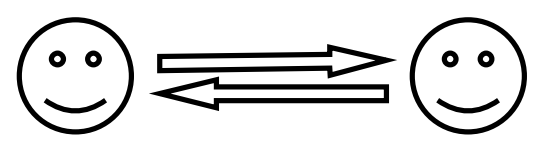

\section{AI - Atenção voltada para objetos iguais ou do mesmo par (semelhantes): cada criança olha para um objeto igual ou parecido (do mesmo par) em relação ao objeto que a outra está olhando.}
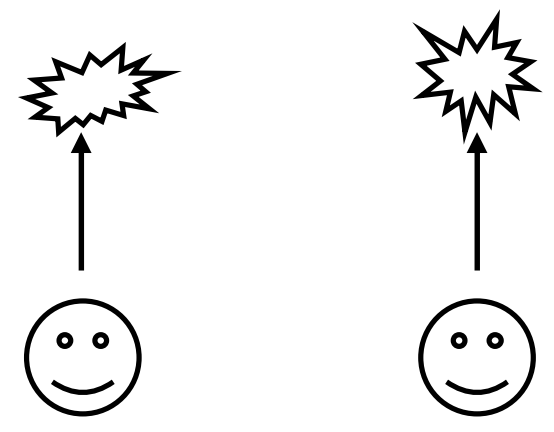

AD - Atenção voltada para objetos ou
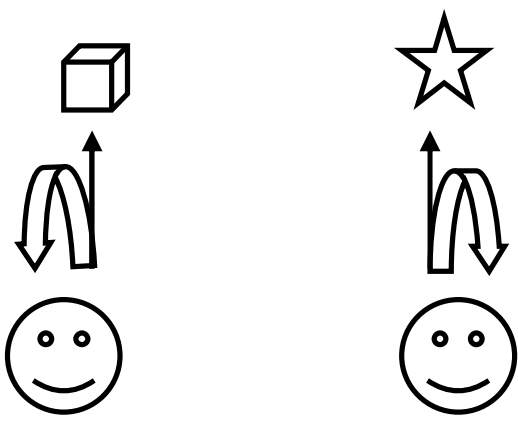
aspectos diferentes do ambiente. cada do ambiente diferente daquele que a outra está olhando.

to


os resultados das duplas com maiores valores de proximidade nos scans (三 maior afinidade social; duplas preferenciais) foram comparados com os daquelas com menores valores de proximidade (三 menor afinidade social; duplas não-preferenciais). $\mathrm{Na} 1^{\mathrm{a}}$ fase, foram consideradas as duplas compostas pela combinação de seis crianças (Alice, Carlos, Gisele, Heitor, Laura e Sílvio), com idades entre 21 e 29 meses, e na $6^{\mathrm{a}}$, as duplas formadas pela combinação das mesmas crianças da $1^{\text {a }}$ fase mais as três que ingressaram no grupo (Bianca, Gustavo e Lia); suas idades estavam compreendidas entre 30 e 37 meses (com exceção de Gustavo, que estava com 21 meses de idade).

Foram analisadas 15 das 21 sessões de duplas da $1^{\text {a }}$ fase - decidiu-se considerar como base o grupo final e, portanto, foram excluídas as seis sessões que tiveram a participação de uma criança que saiu da creche (Meire) - e as 12 sessões da $6^{\mathrm{a}}$ fase. Contudo, na $1^{\mathrm{a}}$ fase, devido ao número de duplas não-preferenciais ser igual a cinco, para equilibrá-lo com o número de sessões de duplas preferenciais (10), foram consideradas apenas as seis duplas com os maiores valores de proximidade.

\section{Resultados}

O número total de registros de orientação da atenção e de eventos não codificáveis foi de $965\left(1^{\mathrm{a}}\right.$ fase $)$ e 1081 ( $6^{\mathrm{a}}$ fase $)$ para as duplas preferenciais, e de $598\left(1^{\mathrm{a}}\right.$ fase $)$ e $1437\left(6^{\mathrm{a}}\right.$ fase), para as não-preferenciais. A Figura 10 mostra que a freqüência de atenção para aspectos diferentes do ambiente (AD) foi maior tanto para as duplas com maior quanto para as com menor afinidade social, nas duas fases, sendo que, na $6^{\mathrm{a}}$ fase, esse valor ultrapassa os 45\% nas duplas com menor afinidade. A segunda categoria mais freqüente foi atenção unilateral (AU), que teve valores parecidos - em torno de $25 \%$ - em ambas as fases. 


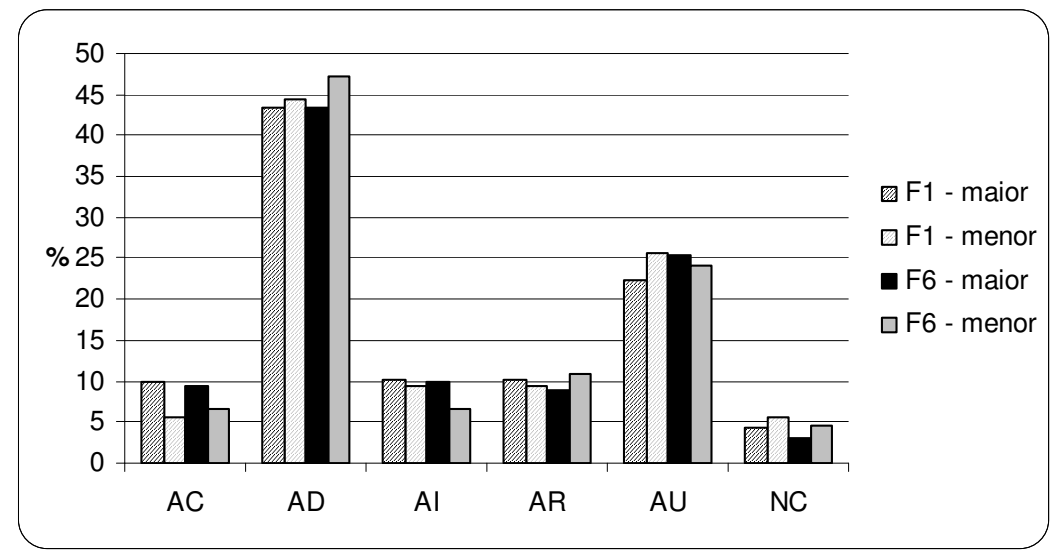

Figura 10 - Histograma das frequiências relativas das categorias de atenção (e de eventos não codificáveis) obtidos para as duplas com maior e para aquelas com menor afinidade social, na primeira (F1) e na sexta fase (F6) de observação em situação semicontrolada.

A análise estatística dos dados (Tabela 7) mostrou que as categorias de atenção estão relacionadas à afinidade social $\left(\chi^{2}=27,218 ; \mathrm{p}<0,05\right)$. As fequências de atenção conjunta (AC) e de atenção para objetos iguais (AI) foram significativamente maiores nas duplas com maior afinidade social do que nas duplas com menor afinidade, e a de atenção para objetos diferentes (AD) apresentou uma tendência a ser significativamente maior nas duplas com menor afinidade do que nas duplas com maior afinidade. Para as outras categorias de atenção, não houve diferença significativa nas duas fases. 
Tabela 7 - $\chi^{2}$ das categorias de atenção e do grau de afinidade social das duplas de crianças consideradas.

\begin{tabular}{|c|c|c|c|c|}
\hline \multirow{2}{*}{\multicolumn{2}{|c|}{ Categoria de atenção }} & \multicolumn{2}{|c|}{ Grau de afinidade } & \multirow{2}{*}{ Total } \\
\hline & & Maior & Menor & \\
\hline \multirow[t]{4}{*}{ Conjunta } & Freqüiência obtida & 195 & 130 & 325 \\
\hline & Freqüência & 162,9 & 162,1 & 325,0 \\
\hline & Resíduo padrão & 2,5 & $-2,5$ & \\
\hline & Resíduo ajustado & 3,7 & $-3,7$ & \\
\hline \multirow[t]{4}{*}{ Unilateral } & Freqüência obtida & 491 & 498 & 989 \\
\hline & Freqüência & 495,8 & 493,2 & 989,0 \\
\hline & Resíduo padrão & $-0,2$ & 0,2 & \\
\hline & Resíduo ajustado & $-0,4$ & 0,4 & \\
\hline \multirow[t]{4}{*}{ Recíproca } & Freqüência obtida & 194 & 214 & 408 \\
\hline & $\begin{array}{l}\text { Freqüência } \\
\text { esperada }\end{array}$ & 204,5 & 203,5 & 408,0 \\
\hline & Resíduo padrão & $-0,7$ & 0,7 & \\
\hline & Resíduo ajustado & $-1,1$ & 1,1 & \\
\hline \multirow{4}{*}{$\begin{array}{l}\text { Objetos iguais } \\
\text { ou semelhantes }\end{array}$} & Freqüência obtida & 204 & 151 & 355 \\
\hline & $\begin{array}{l}\text { Freqüência } \\
\text { esperada }\end{array}$ & 178,0 & 177,0 & 355,0 \\
\hline & Resíduo padrão & 2,0 & $-2,0$ & \\
\hline & Resíduo ajustado & 2,9 & $-2,9$ & \\
\hline \multirow{4}{*}{$\begin{array}{l}\text { Aspectos } \\
\text { diferentes }\end{array}$} & Freqüência obtida & 889 & 944 & 1833 \\
\hline & $\begin{array}{l}\text { Freqüência } \\
\text { esperada }\end{array}$ & 919,0 & 914,0 & 1833,0 \\
\hline & Resíduo padrão & $-1,0$ & 1,0 & \\
\hline & Resíduo ajustado & $-1,9$ & 1,9 & \\
\hline \multirow[t]{4}{*}{ Não codificável } & Freqüência obtida & 73 & 98 & 171 \\
\hline & $\begin{array}{l}\text { Freqüência } \\
\text { esperada }\end{array}$ & 85,7 & 85,3 & 171,0 \\
\hline & Resíduo padrão & $-1,4$ & 1,4 & \\
\hline & Resíduo ajustado & $-2,0$ & 2,0 & \\
\hline \multirow[t]{2}{*}{ Total } & Freqüência obtida & 2046 & 2035 & 4081 \\
\hline & $\begin{array}{l}\text { Freqüência } \\
\text { esperada }\end{array}$ & 2046,0 & 2035,0 & 4081,0 \\
\hline
\end{tabular}

Nota: Valores significativos quando resíduo ajustado $\geq 2,0$ em módulo.

Estes resultados indicam que a maior afinidade social leva as crianças a compartilharem a atenção para um mesmo aspecto do ambiente e a olharem para aspectos iguais ou semelhantes. O compartilhamento da atenção e o foco em objetos iguais ou semelhantes constituem a base para o compartilhamento de significados e para o aprendizado por imitação. O compartilhamento de significados é mais difícil de medir, pois se trata de um 
fenômeno mais qualitativo e discreto, mas a imitação é mais evidente e, portanto, passível de quantificação. Assim, foi realizada uma análise complementar para saber se houve maior freqüência de imitação nas duplas com maior afinidade social do que nas duplas com menor afinidade social (Tabela 8).

Tabela 8 - Número de episódios de imitação detectados nas duplas com maior afinidade social e nas duplas com menor afinidade, na $1^{\mathrm{a}}$ e $6^{\mathrm{a}}$ fases de sessões de díades.

\begin{tabular}{|c|c|}
\hline $1^{\mathrm{a}} \mathrm{FASE}$ & \multirow{2}{*}{ EPISÓDIOS DE IMITAÇÃO } \\
\hline Duplas com maior afinidade social & \\
\hline A-Gi & 2 \\
\hline C-H & $\overline{\mathbf{0}}$ \\
\hline C-S & 23 \\
\hline Gi-H & 1 \\
\hline Gi-La & 4 \\
\hline H-La & 4 \\
\hline Total preferenciais & 34 \\
\hline Média & 5,7 \\
\hline \multicolumn{2}{|l|}{ Duplas com menor afinidade social } \\
\hline $\mathrm{A}-\mathrm{C}$ & 1 \\
\hline A-H & 1 \\
\hline A-La & $\mathbf{0}$ \\
\hline C-Gi & 11 \\
\hline La-S & 1 \\
\hline Total não-preferenciais & 14 \\
\hline Média & 2,8 \\
\hline \multicolumn{2}{|l|}{ 6 } \\
\hline \multicolumn{2}{|l|}{ Duplas com maior afinidade social } \\
\hline A-La & 4 \\
\hline A-Li & 8 \\
\hline B-Gu & 8 \\
\hline C-H & 6 \\
\hline Gi-Gu & 9 \\
\hline Total preferenciais & 35 \\
\hline Média & 7 \\
\hline \multicolumn{2}{|l|}{ Duplas com menor afinidade social } \\
\hline A-B & 5 \\
\hline B-Li & 2 \\
\hline $\mathrm{C}-\mathrm{Li}$ & 1 \\
\hline C-S & 2 \\
\hline Gi-Li & $\mathbf{0}$ \\
\hline Gu-H & 7 \\
\hline La-S & 5 \\
\hline Total não-preferenciais & 22 \\
\hline Média & 3,1 \\
\hline
\end{tabular}


Pode-se observar (Tabela 8) que houve mais episódios de imitação nas duplas com maior afinidade social do que nas duplas com menor afinidade, tanto na $1^{\mathrm{a}}$ fase quanto na $6^{\mathrm{a}}$ fase. Como o número de duplas era diferente em cada situação, calculou-se as médias dos episódios de imitação. Nas duplas com maior afinidade social as médias foram 5,7 (1 $1^{\text {a }}$ fase) e 7 ( $6^{\mathrm{a}}$ fase), enquanto nas duplas com menor afinidade social as médias foram 2,8 ( $1^{\mathrm{a}}$ fase) e 3,1 ( $6^{\mathrm{a}}$ fase). Aplicando-se o Teste-t para amostras independentes não obteve-se significância quando são considerados os valores de imitação das duplas da $1^{\mathrm{a}}$ e da $6^{\mathrm{a}}$ fases $(\mathrm{t}=1,578, \mathrm{p}=$ 0,129). Porém, quando estes valores são considerados em separado, houve diferença significativa entre as duplas com maior afinidade e aquelas com menor afinidade $(t=2,813$, $\mathrm{p}=0,018$ ). Provavelmente o Teste-t não tenha mostrado diferença significatva para a $1^{\mathrm{a}}$ fase de duplas e para as duas fases juntas porque os valores eram muito distintos e a amostra era muito pequena. Assim, pode-se afirmar que, pelo menos na $6^{\mathrm{a}}$ fase, as duplas com maior afinidade social apresentaram significativamente mais episódios de imitação do que as duplas com menor afinidade social. Isto indica que a imitação é mais utilizada como meio de comunicação e, talvez, de transmissão sociocultural entre crianças que têm maior afinidade social entre si do que entre aquelas que têm menor afinidade.

\section{3- Análise complementar do comportamento não-verbal}

A fim de realizar um outro estudo sobre a comunicação entre as crianças - mais amplo em termos de tempo e diferente em relação às categorias descritas no item 5.1 - foram analisados os seus comportamentos não-verbais mais evidentes, como indicativos de comunicação não-verbal. Além da freqüência destes comportamentos, procurou-se verificar quando eles eram ou não acompanhados por verbalizações tanto para outras crianças quanto 
para adultos. Foi feita uma comparação dessas variáveis entre os períodos iniciais (quatro primeiros focais), intermediários (quatro focais intermediários) e finais (quatro últimos focais) das seis crianças que fizeram parte do grupo do início ao fim do período de coleta de dados (1 ano e meio) - Alice, Gisele, Laura, Carlos, Heitor e Sílvio - totalizando 24 focais por período ou 120 minutos por período. Os comportamentos não-verbais e verbalizações das outras crianças do grupo (Meire, Bianca, Lia e Gustavo) também foram contabilizados quando apareciam nos focais selecionados.

O procedimento de análise consistiu em registrar os comportamentos não-verbais mais evidentes conforme eles fossem aparecendo e, a partir daí, criar categorias que pudessem ser utilizadas nos três períodos de focais. Depois, estas categorias foram reunidas com base em sua semelhança em categorias mais amplas, passando a ser subcategorias destas. Trabalhou-se com a idéia de comportamentos não-verbais "mais evidentes" partindo-se do pressuposto de que os comportamentos não-verbais são de difícil identificação e, muitas vezes, passam despercebidos aos olhos do pesquisador. De fato, a maior parte destes comportamentos é composta de padrões complexos, o que exige um estudo minucioso e demorado (microanálise) - Davis (1979) - aquém dos objetivos propostos para a presente pesquisa. As categorias e subcategorias analisadas aparecem a seguir:

- Olhares - incluem "olhar" para ou "observar" (um olhar mais sustentado) e "olhar recíproco", quando duas pessoas olham uma para a outra quase ao mesmo tempo. De acordo com Miller (1976), a maioria das interações sociais é iniciada pelo olhar direto entre duas pessoas. Portanto, mesmo o olhar que não é recíproco pode comunicar ao outro "eu estou prestando atenção em você";

- Contatos amistosos - são contatos físicos geralmente delicados e ou carinhosos, emitidos em situações não-conflituosas. Lee (2004) estudou o toque social como forma de 
comunicação não-verbal em crianças de 5 anos de idade. Engloba as subcategorias: "contato corporal" (encostar com parte do corpo ou com um objeto no corpo do outro); "acariciar" (fazer carinho); "abraçar ou beijar"; "dar a mão" (segurar na mão de outra pessoa); "puxar a mão do outro" (para chamar sua atenção ou pedir alguma coisa);

- Expressões corporais - são modos de expressar, através do corpo, sentimentos, pensamentos ou intenções. Diferenciam-se dos gestos e acenos, por envolverem quase o corpo todo ou serem menos específicos quanto à decodificação de um significado, culturalmente conhecido, pelo pesquisador. Abrangem: "movimento do corpo" (por exemplo, balançar o corpo para frente e para trás ou para os lados); "expressão corporal de braveza" (espernear, bater no próprio corpo, bater num objeto, jogar objetos ao chão); "virar o corpo de frente" para alguém (demonstra interesse em participar de uma interação ou atividade); "virar o corpo de costas" para (demonstra desinteresse em participar de uma interação ou atividade); "separar briga entre duas crianças" (houve apenas um caso, em que uma criança posicionouse entre outras duas que estavam brigando, para tentar separá-las, enquanto verbalizava para elas não brigarem); "expressões corporais de excitação ou de alegria" (baixar e levantar as pernas ou os braços); "bater palmas" (ocorreu tanto como expressão de excitação da criança quanto associada ao cantar parabéns);

- Gestos e acenos - Miller (1979) define gesto como "uma ação ou movimento expressivo, usualmente realizado com as mãos e os braços, mas também com a cabeça ou mesmo o corpo todo" (pp. 253), no entanto, deu-se preferência, aqui, a considerar os gestos como sendo aqueles que envolvem a participação das mãos e dos braços e os acenos como sendo os movimentos da cabeça e o aceno usado para se despedir das pessoas (significando "tchau"). Porém, esta divisão foi apenas uma opção teórica, pois gestos e acenos são muito parecidos e foram colocados na mesma categoria, que engloba as subcategorias: "balançar vertical da cabeça" (aceno significando "sim"); "balançar horizontal da cabeça" (aceno significando 
“não"); "aceno de despedida" (abanar a mão para os lados, significando "tchau”); "estender o braço" em direção a alguém ou a algum objeto que se deseja que a outra pessoa pegue para a criança (pedido); "estender objeto" para alguém (oferecer o objeto); "segurar e mostrar um objeto" (manter um objeto sob a atenção de alguém para mostrá-lo); “apontar” (direcionar, em geral, o dedo indicador para algo ou alguém que a criança quer destacar no ambiente); "sinal de 'não' com o dedo indicador" (balançar o dedo indicador para os lados ao negar alguma coisa); "abrir a boca" (ficar com a boca aberta durante um pequeno intervalo de tempo e esperar ser alimentado - brincadeira de faz-de-conta); "levantar os dois braços para o alto" (levantar os braços à altura da cabeça, dobrá-los e esticá-los, comemorando algo); "fazer gesto para sentar" (bater a mão levemente, com a palma para baixo, sobre o assento que a criança está oferecendo para ser ocupado); "gesto de chamar" (movimentar a mão no sentido da outra pessoa para a criança, com a palma voltada para o próprio corpo, chamando para que o outro se aproxime dela); "gesto de interrogação ou dúvida" (abrir os braços, à altura da cintura, com as palmas das mãos para cima e dobrar levemente os pulsos para baixo); "gesto de confusão" (a criança pára por um momento, põe a mão na cabeça e coça-a ligeiramente, com um ar pensativo e confuso; segundo Davis, 1979, este gesto também pode significar indecisão ou frustração); "gesto de ameaça" (braços levantados à altura do rosto e mãos em formato de garra em direção à pessoa que se quer assustar) e "gesto de assustar" (igual ao gesto de ameaça, porém com mãos abertas e não em formato de garras); "gesto de comer ou beber" (a criança segura um objeto imaginário e leva-o à boca, como se estivesse comendo ou bebendo); "gesto indefinido ou atípico" (subcategoria criada para registrar gestos que foram inventados pelas crianças e que passaram a ter um sentido no grupo);

- Comportamentos agonísticos - são comportamentos não-verbais relacionados ao "agonismo" em si (bater, morder, afastar, empurrar, disputar objeto) ou a brincadeiras que 
contêm componentes agonísticos (brincadeiras turbulentas; por exemplo, "bater de brincadeira"), sempre direcionados a outras pessoas;

- Expressões faciais - foram consideradas as seguintes subcategorias: "sorriso"; "riso"; “choro ou choramingo" e "expressões faciais específicas" (vergonha, preocupação, decepção ou frustração);

- Vocalizações - são expressões vocais não-verbais, ou seja, que não ocorrem por meio de palavras. Todos os sons feitos com a boca pelas crianças foram considerados "vocalizações". Por exemplo: interjeições como "ah", “êh”, "humm...”; imitação de som de água (“chiiii...”); imitação de som de motor "vrum"; etc. Também foram registradas, separadamente, as vocalizações alternadas entre duas ou mais crianças;

- Imitação - partindo da concepção de imitação como um "ato" de identificação entre os sujeitos envolvidos na interação e como uma espécie de convite para a interação, ela foi concebida como uma forma de comunicação não-verbal.

É importante destacar que a criação de categorias de comportamentos indicativos de comunicação não-verbal foi mais trabalhosa do que a de categorias de verbalizações (item 5.4). A comunicação não-verbal é muito mais subjetiva e, como afirma Miller (1976), não existe um dicionário ou gramática de comunicação não-verbal para ser consultado pelos pesquisadores (ou quaisquer outras pessoas) quando têm dúvidas sobre o assunto.

Adicionalmente, foram registradas as referências dos comportamentos emitidos pelas crianças, ou seja, para quem eles foram dirigidos: elas próprias, outra(s) criança(s), educadora, pesquisadora ou pessoa ausente. Decidiu-se não considerar os objetos como referências, porque é mais difícil identificar não-verbais para eles. A direção do comportamento era determinada, muitas vezes, conforme o olhar da criança e, nestes casos, o olhar não era contado - por exemplo, quando a criança sorria olhando para alguém, tabulava-se somente 
"sorriso" (e não "olhar" e "sorriso"). Além disso, sempre que havia uma verbalização acompanhando um comportamento não-verbal, ela era tabulada, separando-se verbalizações dirigidas para adultos de verbalizações direcionadas para outras crianças.

\section{Resultados}

Pode-se observar (Apêndice 7 e Tabela 9) que, nos focais iniciais, foram registrados, ao todo, 465 eventos de comportamento não-verbal, dos quais as categorias "olhares" (subcategoria "olhar/observar"), "vocalizações" (subcategoria "vocalização") e “expressões faciais" (subcategorias "sorriso" e "riso") foram as mais freqüentes $(26,24 \%, 20,86 \%$ e $17,63 \%$, respectivamente), enquanto as categorias "contatos amistosos" (subcategorias "dar a mão" e "puxar a mão do outro") e "imitação" foram as menos freqüentes $(3,66 \%$ e 5,81\%).

Nos focais intermediários, foram identificados 285 eventos de comportamento nãoverbal (Apêndice 8 e Tabela 9), tendo tido maior freqüência as categorias "olhares" (24,56\%; subcategoria "olhar/observar"), "gestos e acenos" (17,19\%; subcategoria "estender objeto para"), "expressões faciais" (16,84\%; subcategoria "riso") e vocalizações (16,84\%; subcategoria "vocalizações"), e menor freqüência as categorias "contatos amistosos" (4,21\%; subcategorias "acariciar"e "puxar a mão do outro"), "expressões corporais" (4,91\%; subcategorias "separar briga entre duas crianças" e "expressões corporais de excitação") e “imitação" $(6,32 \%)$.

Nos focais finais, foram computados 230 eventos de comportamento não-verbal (Apêndice 9 e Tabela 9), sendo a maioria de "olhares" (26,52\%; subcategoria “olhar/observar"), “expressões faciais" (21,74\%; subcategorias "riso" e "sorriso") e "imitação" (12,61\%, frequiência duas vezes maior do que nos períodos anteriores), e a minoria de "contatos amistosos" (2,61\%; subcategorias "abraçar, beijar", "dar a mão para" e "puxar a 
mão do outro"), "expressões corporais" (6,52\%\%; subcategorias "virar o corpo de costas para", "separar briga entre duas crianças" e "expressões corporais de excitação") e "vocalizações" (8,70\%, freqüência duas vezes menor do que nos períodos anteriores).

Resumindo, tomando-se os comportamentos não-verbais analisados como forma de comunicação entre as crianças, elas se comunicaram mais via "olhares" e "expressões faciais" e menos via "contatos amistosos", nos três períodos de focais. Além disso, atentando-se apenas às subcategorias (Tabela 9), "puxar a mão do outro", "separar briga entre duas crianças", "expressões corporais de excitação", "aceno de despedida", "fazer gesto para sentar" e "vocalização alternada", foram encontradas somente nos focais iniciais; "balançar vertical da cabeça", "sinal de 'não' com o dedo indicador”, "abrir a boca" e "gesto de beber ou comer", foram observados apenas nos focais intermediários; enquanto "gesto de chamar" e "gesto de confusão", foram vistos somente nos focais finais. Este resultado pode ser explicado, em parte, devido à construção das subcategorias ter ocorrido à medida que elas fossem aparecendo, portanto, elas poderiam estar presentes num período de focais e em outro não. Quanto à variedade de modos de comunicação não-verbal, nos focais iniciais houve maior diversidade de subcategorias (apenas sete não foram observadas), o contrário do que ocorreu nos focais finais (14 subcategorias não foram encontradas). Parece que nos focais inicias as crianças se comunicaram mais não-verbalmente, tanto pelo número total de eventos de comportamentos não-verbais encontrados (465), como pela maior variedade destes comportamentos. 
Tabela 9 - Freqüência relativa (em relação ao total de não-verbais detectados em cada período de focais) das categorias dos comportamentos não-verbais indicativos de comunicação obtidos nos focais iniciais (21/8/03 a 22/9/03), intermediários (25/3/04 a 28/4/04) e finais (13/10/04 a 16/11/04), das crianças A, C, Gi, H, La e S.

\begin{tabular}{|c|c|c|c|}
\hline Não-verbal emitido / Focais & Iniciais (\%) & Intermediários (\%) & Finais $(\%)$ \\
\hline Olhares & 26,24 & 24,56 & 26,52 \\
\hline Olhar/observar & 22,58 & 22,46 & 23,48 \\
\hline Olhar recíproco & 3,66 & 2,11 & 3,04 \\
\hline Contatos amistosos & 3,66 & 4,21 & 2,61 \\
\hline Contato corporal & 2,15 & 2,46 & 2,17 \\
\hline Acariciar & 0,43 & 0,00 & 0,43 \\
\hline Abraçar, beijar & 0,65 & 0,70 & 0,00 \\
\hline Dar a mão para & 0,22 & 1,05 & 0,00 \\
\hline Puxar a mão do outro & 0,22 & 0,00 & 0,00 \\
\hline Expressões corporais & $\mathbf{7 , 7 4}$ & 4,91 & $\mathbf{6 , 5 2}$ \\
\hline Movimento do corpo & 1,72 & 0,70 & 0,87 \\
\hline Expressão corporal de braveza & 2,37 & 0,70 & 0,87 \\
\hline Virar o corpo de frente para & 1,29 & 2,11 & 3,04 \\
\hline Virar o corpo de costas para & 1,51 & 0,70 & 0,00 \\
\hline Separar briga entre duas crianças & 0,22 & 0,00 & 0,00 \\
\hline Expressões corporais de excitação & 0,43 & 0,00 & 0,00 \\
\hline Bater palmas & 0,22 & 0,70 & 1,74 \\
\hline Gestos e acenos & $\mathbf{6 , 8 8}$ & 17,19 & 10,87 \\
\hline Balançar vertical da cabeça ("sim") & 0,00 & 0,35 & 0,00 \\
\hline Balançar horizontal da cabeça ("não") & 0,00 & 1,05 & 0,43 \\
\hline Estender o braço (pedido) & 1,72 & 1,40 & 0,43 \\
\hline Estender objeto para & 2,15 & 6,32 & 6,09 \\
\hline Segurar e mostrar um objeto & 0,43 & 0,35 & 0,87 \\
\hline Apontar & 0,43 & 3,51 & 0,43 \\
\hline Aceno de despedida & 0,22 & 0,00 & 0,00 \\
\hline Sinal de "não" com o dedo indicador & 0,00 & 0,70 & 0,00 \\
\hline Abrir a boca (pedindo comida) & 0,00 & 0,70 & 0,00 \\
\hline $\begin{array}{l}\text { Levantar os braços para o alto } \\
\text { (comemorar) }\end{array}$ & 0,00 & 0,35 & 0,87 \\
\hline Fazer gesto para sentar & 0,65 & 0,00 & 0,00 \\
\hline Gesto de chamar & 0,00 & 0,00 & 0,43 \\
\hline Gesto de interrogação/dúvida & 0,22 & 0,35 & 0,00 \\
\hline Gesto de confusão & 0,00 & 0,00 & 0,43 \\
\hline Gesto de ameaça ou de assustar & 0,43 & 1,40 & 0,00 \\
\hline Gesto de beber ou comer & 0,00 & 0,70 & 0,00 \\
\hline Gesto indefinido, atípico & 0,65 & 0,00 & 0,87 \\
\hline Comportamentos agonísticos & 11,18 & 9,12 & 10,43 \\
\hline Agonismo & 9,89 & 8,42 & 6,52 \\
\hline Bater de brincadeira (turbulenta) & 1,29 & 0,70 & 3,91 \\
\hline Expressões faciais & 17,63 & 16,84 & 21,74 \\
\hline Sorriso & 6,45 & 4,21 & 8,70 \\
\hline Riso & 7,10 & 8,07 & 10,00 \\
\hline Choro, choramingo & 3,01 & 2,81 & 1,30 \\
\hline Expressão facial específica & 1,08 & 1,75 & 1,74 \\
\hline Vocalizações & 20,86 & 16,84 & 8,70 \\
\hline Vocalização & 20,43 & 16,84 & 8,70 \\
\hline Vocalização alternada & 0,43 & 0,00 & 0,00 \\
\hline Imitação & 5,81 & 6,32 & 12,61 \\
\hline
\end{tabular}


A Figura 11 mostra uma comparação das freqüências das categorias de comportamento não-verbal registradas nos três períodos de focais. É interessante notar a maior diferença em freqüência, entre os períodos, das categorias "gestos e acenos", "vocalizações" e "imitação". "Gestos e acenos" foram mais freqüentes nos focais intermediários do que nos iniciais ou finais, "imitação" foi mais freqüente nos focais finais do que nos dos períodos anteriores e, finalmente, "vocalizações" teve um decréscimo acentuado dos focais iniciais para os finais. As outras categorias não apresentaram grandes variações entre os três períodos analisados. Estes dados serão mais bem compreendidos quando forem abordadas as freqüências de verbalizações que acompanharam os comportamentos nãoverbais.

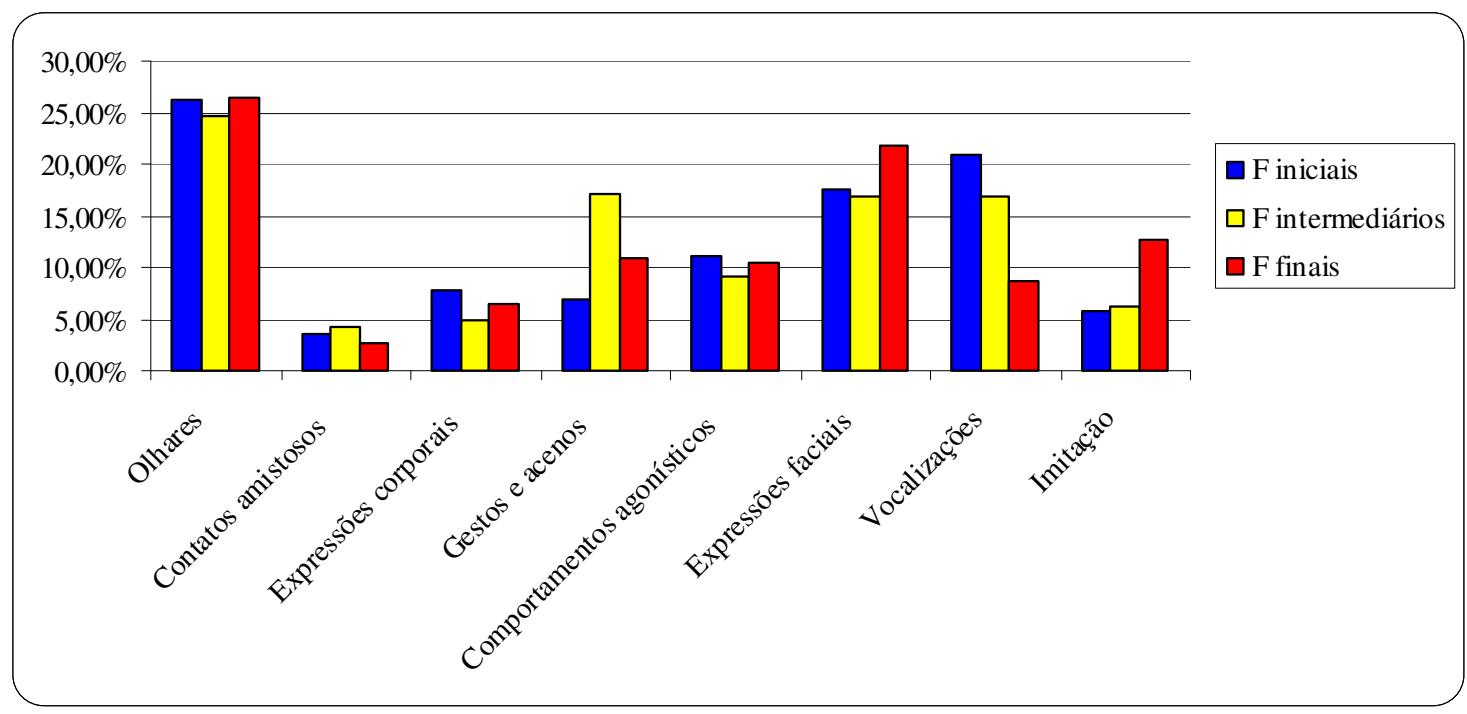

Figura 11 - Freqüências relativas das categorias dos comportamentos não-verbais indicativos de comunicação obtidos nos focais $(F)$ iniciais (21/8/03 a 22/9/03), intermediários (25/3/04 a 28/4/04) e finais (13/10/04 a 16/11/04), das crianças A, C, Gi, H, La e S.

A análise estatística dos dados (Tabela 10) revelou que houve associação significativa entre períodos e categorias de comportamento não-verbal $\left(\chi^{2}=46,688\right.$, $\left.g l=14, p=0\right)$. Nos focais iniciais, as frequiências de "gestos e acenos" e de "imitação" foram significativamente menores do que as esperadas (resíduos ajustados iguais a, respectivamente, -3,8 e -2,0), 
enquanto a freqüência de "vocalizações" foi significativamente maior do que a esperada (resíduo ajustado $=3,1$ ). Nos focais intermediários, a freqüência de "gestos e acenos" foi significativamente maior do que a esperada (resíduo ajustado $=4,1$ ). Nos focais finais a freqüência de "vocalizações" foi significativamente menor do que a esperada (resíduo ajustado $=-3,7)$ e a freqüência de "imitação" foi significativamente maior do que a esperada (resíduo ajustado $=3,3$ ).

Tabela 10 - Distribuição das categorias de comportamentos não-verbais indicativos de comunicação nos períodos de focais iniciais (21/8/03 a 22/9/03), intermediários (25/3/04 a 28/4/04) e finais (13/10/04 a 16/11/04).

Categorias * Períodos Crosstabulation

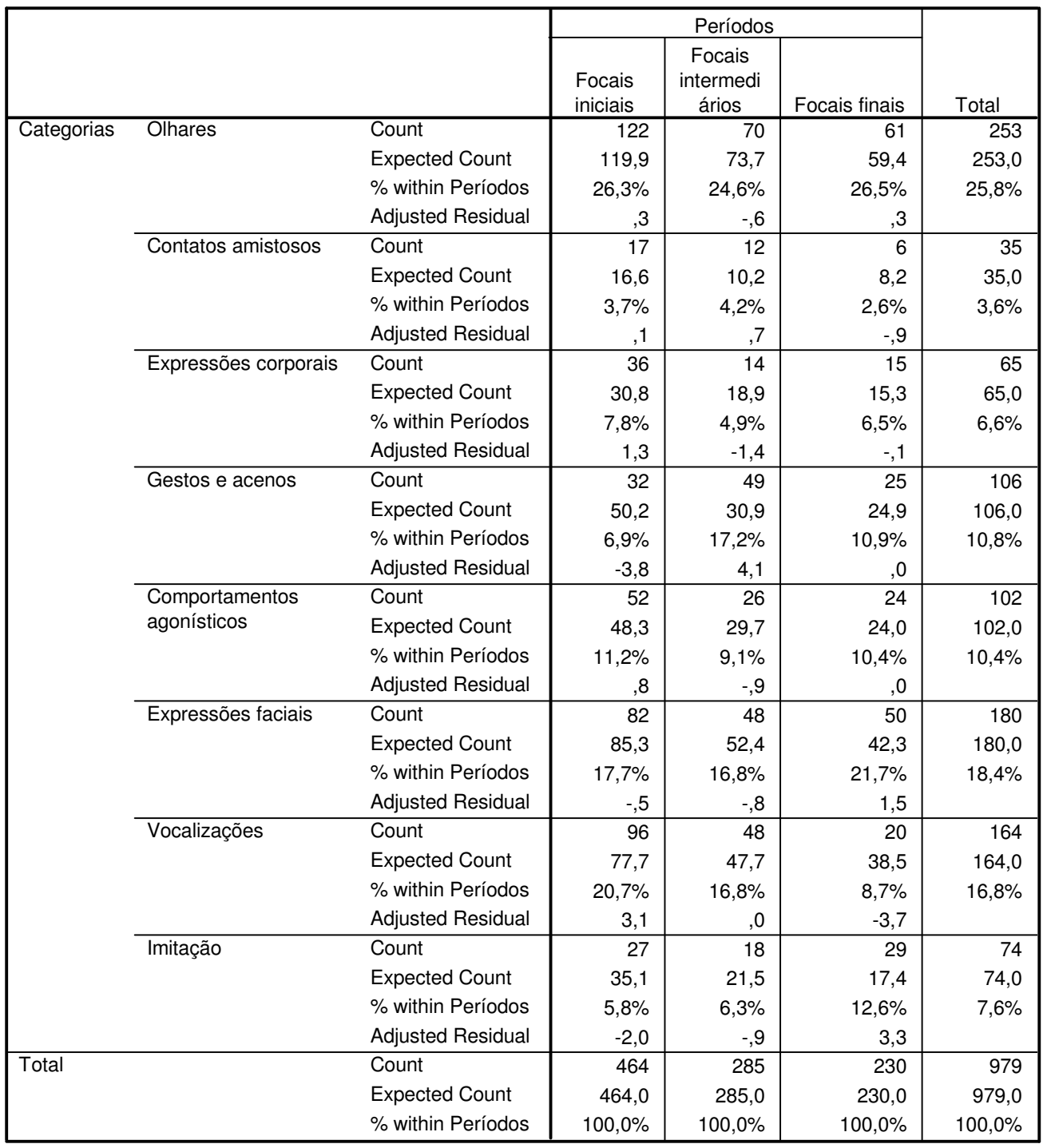

Nota: Valores significativos quando resíduo ajustado $\geq 2,0$, em módulo. 
A Figura 12 mostra que houve uma diminuição na freqüência de comportamentos nãoverbais indicativos de comunicação dos focais iniciais para os intermediários e destes para os finais. Esta diferença entre os períodos foi significativa $\left(\chi^{2}=92,500, \mathrm{gl}=2, \mathrm{p}=0\right)$.

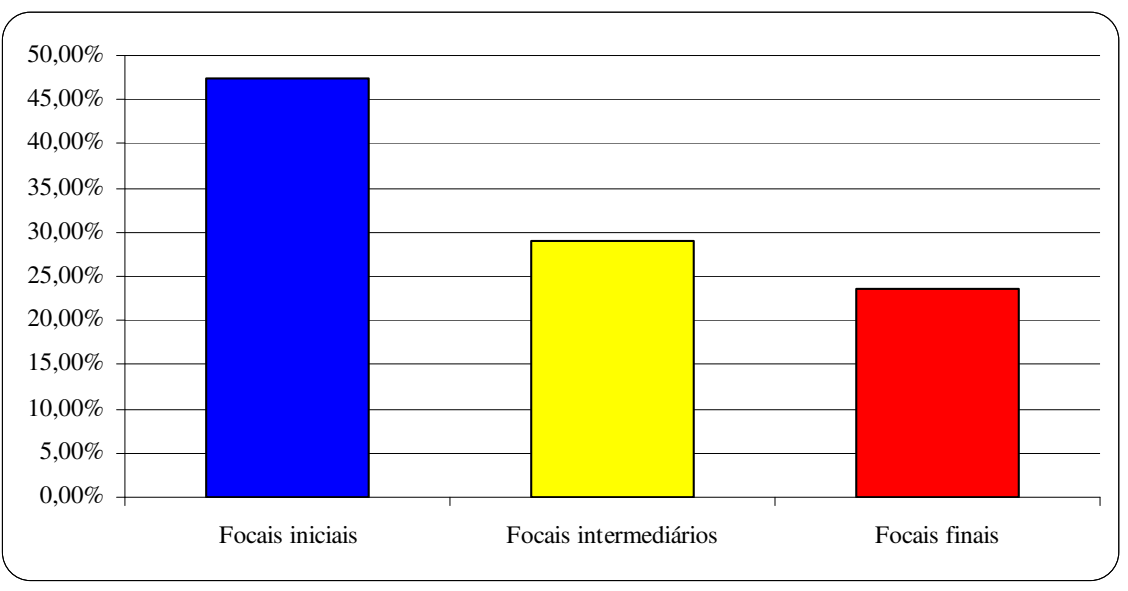

Figura 12 - Freqüências relativas dos comportamentos não-verbais indicativos de comunicação obtidos nos focais iniciais (21/8/03 a 22/9/03), intermediários (25/3/04 a 28/4/04) e finais (13/10/04 a 16/11/04), das crianças A, C, Gi, H, La e S.

Quanto à referência dos comportamentos não-verbais emitidos pelas crianças, pode-se observar (Figura 13) que a maior parte deles foi direcionada a outra(s) criança(s), nos três períodos de focais analisados, e que "educadora" foi a segunda categoria mais freqüente. Isto se deve, em parte, ao método de coleta de dados adotado que prioriza a interação criançacriança e à cooperação das educadoras em interferir o mínimo possível nesta interação. Mas, de qualquer jeito, as educadoras estavam presentes e as crianças podiam recorrer a elas quando quisessem, e os índices de comportamentos não-verbais orientados para outra(s) criança(s) foram bastante altos (75 a 86\%), tendo aumentado ligeiramente de um período de focais para o seguinte. Isto reflete, provavelmente, o maior nível de entrosamento entre as crianças à medida que elas passam mais tempo juntas e compartilham mais vivências. Como 
afirma Casalderrey (1992), parece que há um atrativo especial em observar atentamente as ações de outra criança, em olhá-la, sorrir-lhe e imitá-la.

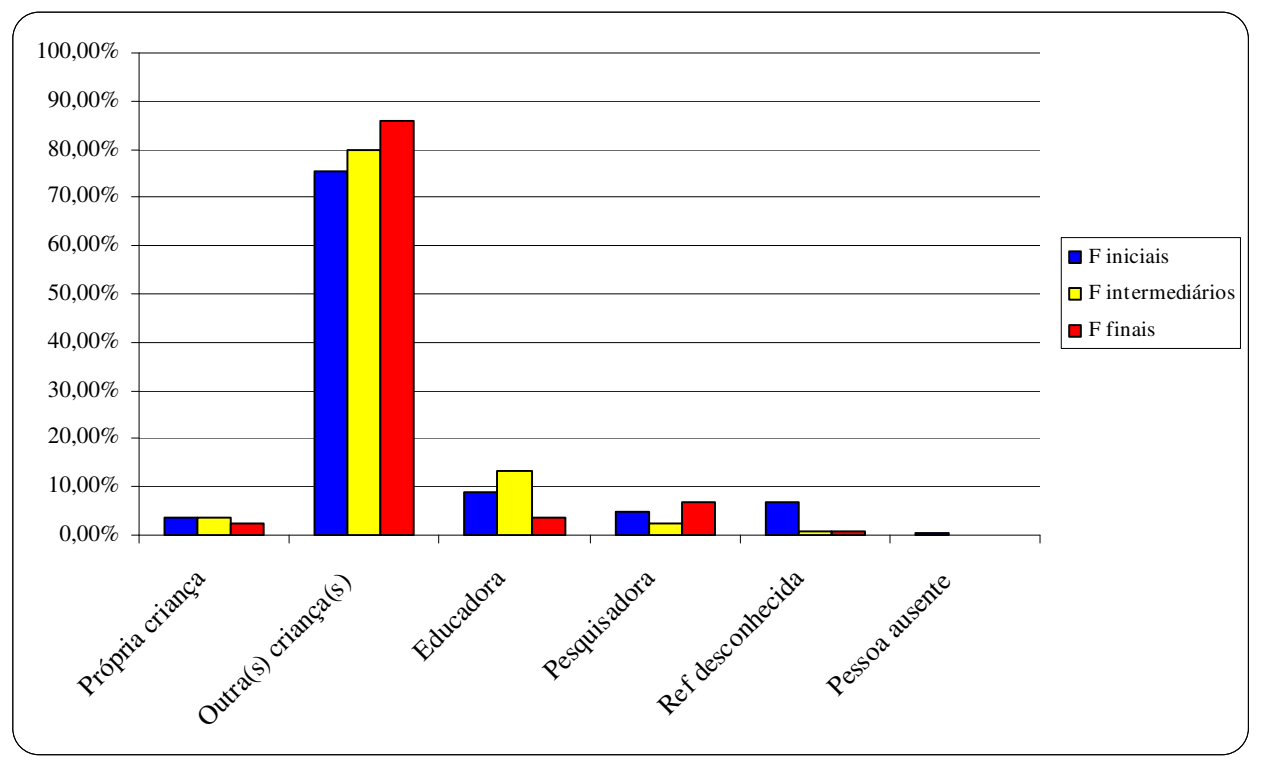

Figura 13 - Freqüências relativas das categorias de referência dos comportamentos nãoverbais indicativos de comunicação obtidos nos focais (F) iniciais (21/8/03 a 22/9/03), intermediários (25/3/04 a 28/4/04) e finais (13/10/04 a 16/11/04), das crianças A, C, Gi, H, La e S.

A análise estatística indicou que houve associação significativa entre as categorias de referência e os períodos $\left(\chi^{2}=47,058, \mathrm{gl}=8, \mathrm{p}=0\right)$. Nos focais iniciais, a freqüência de emissão de comportamentos não-verbais para "outra(s) criança(s)" foi significativamente menor do que a esperada $(-2,7)$; por outro lado a freqüência para "referência desconhecida" foi significativamente maior do que a esperada $(5,1)$. Nos focais intermediários, a freqüência de emissão de comportamentos não-verbais para "educadora" foi significativamente maior do que a esperada $(3,1)$, enquanto as freqüências para "pesquisadora" e "referência desconhecida" foram significativamente menores do que as esperadas (resíduos ajustados iguais a, respectivamente, -2,1 e -3,1). Já nos focais finais, a freqüência de emissão de comportamentos não-verbais para "outra(s) criança(s)" foi significativamente maior do que a 
esperada $(2,9)$ e as freqüências para "educadora" e "referência desconhecida" foram significativamente menores do que as esperadas (resíduos ajustados, respectivamente, iguais a $-3,3$ e $-2,6)$

Tabela 11 - Distribuição das categorias de referência dos comportamentos não-verbais indicativos de comunicação nos períodos de focais iniciais (21/8/03 a 22/9/03), intermediários $(25 / 3 / 04$ a 28/4/04) e finais (13/10/04 a 16/11/04).

\begin{tabular}{|c|c|c|c|c|c|c|}
\hline \multicolumn{7}{|c|}{ Referência * Período Crosstabulation } \\
\hline & & & \multicolumn{3}{|c|}{ Período } & \multirow[b]{2}{*}{ Total } \\
\hline & & & $\begin{array}{l}\text { Focais } \\
\text { iniciais }\end{array}$ & $\begin{array}{c}\text { Focais } \\
\text { intermedi } \\
\text { ários }\end{array}$ & Focais finais & \\
\hline \multirow[t]{20}{*}{ Referência } & \multirow[t]{4}{*}{ Própria criança } & Count & 17 & 10 & 6 & 33 \\
\hline & & Expected Count & 15,6 & 9,6 & 7,8 & 33,0 \\
\hline & & \% within Período & $3,7 \%$ & $3,5 \%$ & $2,6 \%$ & $3,4 \%$ \\
\hline & & Adjusted Residual &, 5 & ,2 &,- 7 & \\
\hline & \multirow[t]{4}{*}{ Outra(s) criança(s) } & Count & 351 & 228 & 198 & 777 \\
\hline & & Expected Count & 368,3 & 226,2 & 182,5 & 777,0 \\
\hline & & \% within Período & $75,6 \%$ & $80,0 \%$ & $86,1 \%$ & $79,4 \%$ \\
\hline & & Adjusted Residual & $-2,7$ & ,3 & 2,9 & \\
\hline & \multirow[t]{4}{*}{ Educadora } & Count & 41 & 38 & 8 & 87 \\
\hline & & Expected Count & 41,2 & 25,3 & 20,4 & 87,0 \\
\hline & & \% within Período & $8,8 \%$ & $13,3 \%$ & $3,5 \%$ & $8,9 \%$ \\
\hline & & Adjusted Residual &,- 1 & 3,1 & $-3,3$ & \\
\hline & \multirow[t]{4}{*}{ Pesquisadora } & Count & 23 & 7 & 16 & 46 \\
\hline & & Expected Count & 21,8 & 13,4 & 10,8 & 46,0 \\
\hline & & \% within Período & $5,0 \%$ & $2,5 \%$ & $7,0 \%$ & $4,7 \%$ \\
\hline & & Adjusted Residual & ,4 & $-2,1$ & 1,9 & \\
\hline & \multirow[t]{4}{*}{ Referência desconhecida } & Count & 32 & 2 & 2 & 36 \\
\hline & & Expected Count & 17,1 & 10,5 & 8,5 & 36,0 \\
\hline & & \% within Período & $6,9 \%$ &, $7 \%$ &, $9 \%$ & $3,7 \%$ \\
\hline & & Adjusted Residual & 5,1 & $-3,2$ & $-2,6$ & \\
\hline \multirow{3}{*}{\multicolumn{2}{|c|}{ Total }} & Count & 464 & 285 & 230 & 979 \\
\hline & & Expected Count & 464,0 & 285,0 & 230,0 & 979,0 \\
\hline & & $\%$ within Período & $100,0 \%$ & $100,0 \%$ & $100,0 \%$ & $100,0 \%$ \\
\hline
\end{tabular}

Nota: Valores significativos quando resíduo ajustado $\geq 2,0$, em módulo.

Analisando-se os tipos de comportamentos não-verbais encontrados para cada categoria de referência, os comportamentos dirigidos à própria criança foram (Apêndices 7,8 e 9): "sorriso", "riso", "choro (ou choramingo)", "vocalização", "movimento do corpo", "bater palmas", "levantar os braços para o alto (comemorar)", "gesto de interrogação ou dúvida", e "gesto de beber ou comer". 
Para a referência "outra(s) criança(s)", os comportamentos não-verbais mais freqüentes foram (Apêndices 7, 8 e 9): 1) Focais inicias - "olhares" ("olhar ou observar" 18,49\%), "vocalizações" ("vocalização" - 11,18\%), e "expressões faciais" ("sorriso" - 4,09\% e "riso" - 4,52\%) "comportamentos agonísticos" ("agonismo" - 9,89\%); 2) Focais intermediários - "olhares" ("olhar ou observar" - 18,95\%), "vocalizações" ("vocalização" 14,04\%) e "expressões faciais" ("riso" - 7,72\%); 3) Focais finais - "olhares" ("olhar ou observar" - 18,26\%), "expressões faciais" ("sorriso" - 7,83\% e "riso" - 8,26\%), "imitação" $(12,61 \%)$ e "gestos e acenos" ("estender objeto para" - 5,22\%). Os comportamentos nãoverbais que foram emitidos apenas para "outra(s) criança(s)" como referência foram: "olhar recíproco", "segurar e mostrar um objeto", "agonismo" e "bater de brincadeira (turbulenta)". Realmente, agonismo e brincadeira turbulenta são comportamentos mais prováveis de serem direcionados de uma criança para outra. A presença de olhar recíproco entre as crianças indica que havia intimidade e cumplicidade entre elas, mesmo que a freqüência registrada deste comportamento tenha sido baixa.

Considerando a referência "educadora", os comportamentos não-verbais mais comuns foram (Apêndices 7, 8 e 9): 1) Focais inicias - "gestos e acenos" ("estender objeto para" $1,51 \%$ e "estender o braço" - 0,86\%) e "expressões faciais" ("sorriso" - 1,08\% e "riso" 0,86\%); 2) Focais intermediários - "gestos e acenos" ("estender objeto para" - 2,46\% e “apontar"- 2,11\%); 3) Focais finais - "olhares" ("olhar ou observar" - 1,74\%\%). Comportamentos emitidos exclusivamente para educadora foram: "dar a mão para" (uma ocorrência), "balançar vertical da cabeça" (uma ocorrência) e "sinal de 'não' com o dedo indicador" (duas ocorrências).

Quanto à pesquisadora como referência, "olhares" e "expressões faciais" foram os comportamentos não-verbais mais freqüentemente emitidos pelas crianças, demonstrando que ela conseguiu ficar razoavelmente neutra em sua posição de observadora. 
No que concerne às verbalizações emitidas para adultos ou crianças e que acompanharam os comportamentos não-verbais analisados, foram contabilizadas ao todo 102 verbalizações, das quais quase $40 \%$ nos focais intermediários e a maioria para outras crianças (79,41\% - Tabela 11). As frequiências de verbalizações "para adultos" se aproximaram daquelas obtidas "para as crianças" apenas nos focais intermediários $(42,50 \%$ e 57,50\%, respectivamente). Nos focais finais, todas as verbalizações acompanhadas de comportamentos não-verbais foram emitidas para outras crianças.

Tabela 12 - Frequiências absoluta $(\mathrm{Fa})$ e relativa $(\mathrm{Fr})$ de verbalizações dirigidas a outras crianças ou a adultos (educadoras ou pesquisadora), que acompanharam os comportamentos não-verbais indicativos de comunicação, obtidas nos focais iniciais (21/8/03 a 22/9/03), intermediários (25/3/04 a 28/4/04) e finais (13/10/04 a 16/11/04), das crianças A, C, Gi, H, La e S.

\begin{tabular}{l|c|c|c|c|c|c}
\hline \multirow{2}{*}{ Focais } & \multicolumn{2}{|c|}{ Verbal (para criança) } & \multicolumn{2}{c|}{ Verbal (para adulto) } & \multicolumn{2}{c}{ Total } \\
\cline { 2 - 7 } & $\mathrm{Fa}$ & $\mathrm{Fr}(\%)$ & $\mathrm{Fa}$ & $\mathrm{Fr}(\%)$ & $\mathrm{Fa}$ & $\mathrm{Fr}(\%)$ \\
\hline Iniciais & 24 & 85,71 & 4 & 14,29 & 28 & 27,45 \\
\hline Intermediários & 23 & 57,50 & 17 & 42,50 & 40 & 39,22 \\
\hline Focais & 34 & 100,00 & 0 & 0,00 & 34 & 33,33 \\
\hline Total & 81 & 79,41 & 21 & 20,59 & 102 & 100,00 \\
\hline
\end{tabular}

A Figura 14 apresenta mais claramente a proporção de cada referência das verbalizações das crianças acompanhadas de comportamentos não verbais, registradas nos três períodos de focais. 


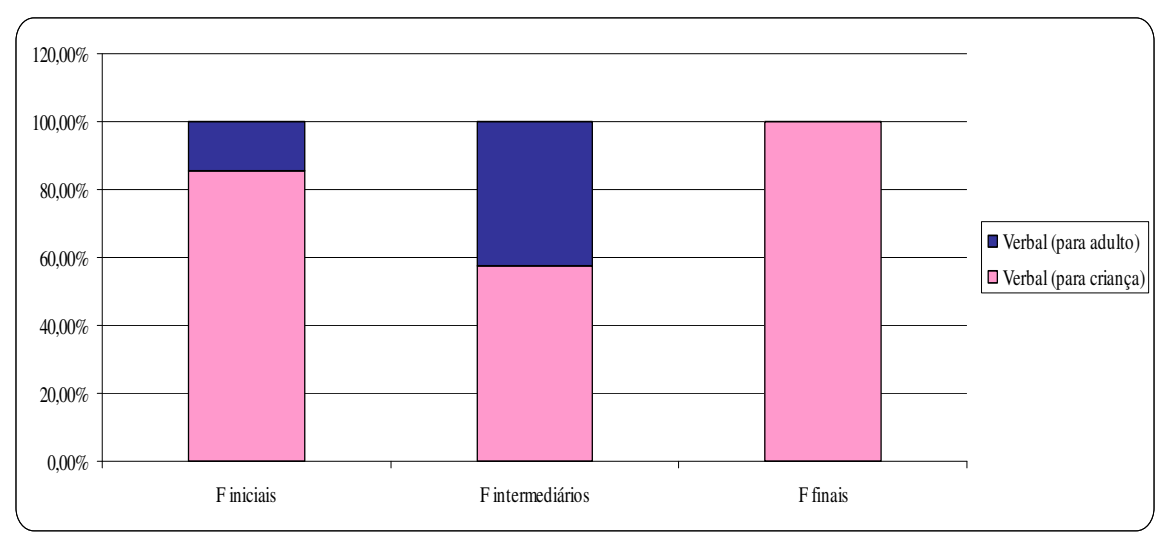

Figura 14 - Freqüências relativas das verbalizações dirigidas para adultos ou outras crianças, que acompanharam os comportamentos não-verbais indicativos de comunicação, obtidas nos focais (F) iniciais (21/8/03 a 22/9/03), intermediários (25/3/04 a 28/4/04) e finais (13/10/04 a 16/11/04), das crianças A, C, Gi, H, La e S.

Submetendo-se os dados sobre verbalizações que acompanharam os comportamentos não-verbais das crianças à análise estatística, (Tabela 13) obteve-se associação significativa entre períodos e referências das verbalizações $\left(\chi^{2}=21,242, \mathrm{gl}=2, \mathrm{p}=0\right)$. Nos focais intermediários, a frequiência de verbalizações para criança foi significativamente menor do que a esperada $(-4,4)$ e, para adulto, a freqüência foi significativamente maior do que a esperada $(4,4)$. Porém, esta situação se inverteu nos focais finais (resíduo ajustado para criança $=3,6$ e para adulto $=-3,6)$. 
Tabela 13 - Distribuição das verbalizações (para criança ou para adulto) que acompanharam os comportamentos não-verbais indicativos de comunicação, nos períodos de focais iniciais (21/8/03 a 22/9/03), intermediários (25/3/04 a 28/4/04) e finais (13/10/04 a 16/11/04).

Período * Verbal Crosstabulation

\begin{tabular}{|lll|r|r|r|}
\hline & & \multicolumn{2}{|c|}{ Verbal } & \\
\cline { 3 - 5 } & & Para criança & Para adulto & \multicolumn{1}{|c|}{ Total } \\
\hline Período & Focais iniciais & Count & 4 & 28 \\
& & Expected Count & 22,2 & 5,8 & 28,0 \\
& & $\%$ within Período & $85,7 \%$ & $14,3 \%$ & $100,0 \%$ \\
& & Adjusted Residual & 1,0 & $-1,0$ & \\
\cline { 2 - 5 } & & 23 & 17 & 40 \\
& Focais intermediários & Count & 31,8 & 8,2 & 40,0 \\
& & Expected Count & $57,5 \%$ & $42,5 \%$ & $100,0 \%$ \\
& & \% within Período & $-4,4$ & 4,4 & \\
\cline { 3 - 5 } & Focais finais & Coususted Residual & 34 & 0 & 34 \\
& & Expected Count & 27,0 & 7,0 & 34,0 \\
& & \% within Período & $100,0 \%$ &, $0 \%$ & $100,0 \%$ \\
& & Adjusted Residual & 3,6 & $-3,6$ & \\
\hline Total & & 81 & 21 & 102 \\
& & Count & 81,0 & 21,0 & 102,0 \\
& & Expected Count & $79,4 \%$ & $20,6 \%$ & $100,0 \%$ \\
\hline
\end{tabular}

Nota: Valores significativos quando resíduo ajustado $\geq 2,0$, em módulo.

Em relação aos tipos de comportamentos não-verbais acompanhados por verbalizações emitidas para outras crianças, pode-se verificar (Figura 15) que as maiores freqüências foram encontradas para: "estender objeto para" (oferecer), principalmente nos focais intermediários e finais; "agonismo" (focais iniciais e intermediários); "vocalização" (focais intermediários); e "imitação" (somente nos focais finais). Além disso, não houve muita diferença no número de tipos diversos de comportamentos não-verbais acompanhados de verbalizações entre os períodos de focais iniciais (13 tipos), intermediários (10 tipos) e finais (12 tipos). 


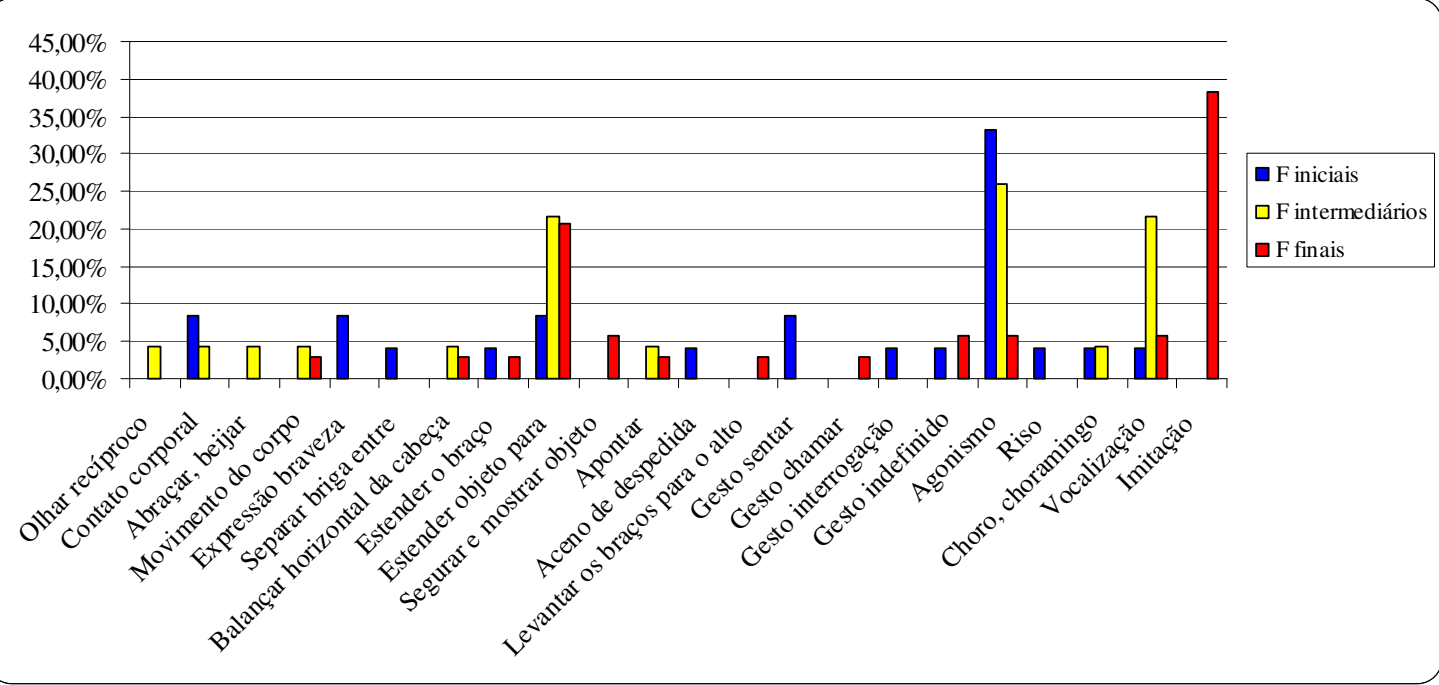

Figura 15 - Freqüências relativas das verbalizações direcionadas a outras crianças, para cada tipo de comportamento não-verbal indicativo de comunicação, obtidas nos focais $(F)$ iniciais (21/8/03 a 22/9/03), intermediários (25/3/04 a 28/4/04) e finais (13/10/04 a 16/11/04), das crianças A, C, Gi, H, La e S. OBS.: Não foram representados na Figura os comportamentos não-verbais que não foram acompanhados de verbalizações em nenhum período.

As maiores freqüências de verbalizações acompanhando "estender objeto para" e "imitação" coincidiram com as maiores freqüências destes comportamentos não-verbais (ou seja, mesmos períodos de focais), diferentemente do que ocorreu para "vocalização" e “agonismo". Estes resultados indicam que ao oferecer um objeto para outra criança ou imitála, era comum as crianças falarem também; no entanto, ao vocalizarem ou apresentarem um comportamento agonístico, era menos comum que as crianças falassem.

Já quando se considera o adulto como alvo da comunicação (Figura 16), nos focais iniciais apenas quatro tipos de comportamentos não-verbais foram acompanhados de verbalizações e com a mesma freqüência (25,00\%): “expressão corporal de braveza", “estender o braço (pedido)", “apontar” e "vocalização". Nos focais intermediários, houve seis tipos de comportamentos não-verbais acompanhados de verbalizações: "movimento do corpo", "balançar vertical da cabeça" e "sinal de "não' com o dedo" (cada um com 5,88\% de freqüência); "apontar" (35,30\%), “estender objeto para" $(29,41 \%)$ e "estender o braço 
(pedido)" (17,65\%). Nos focais finais, nenhum comportamento não-verbal foi acompanhado de verbalização para adulto.

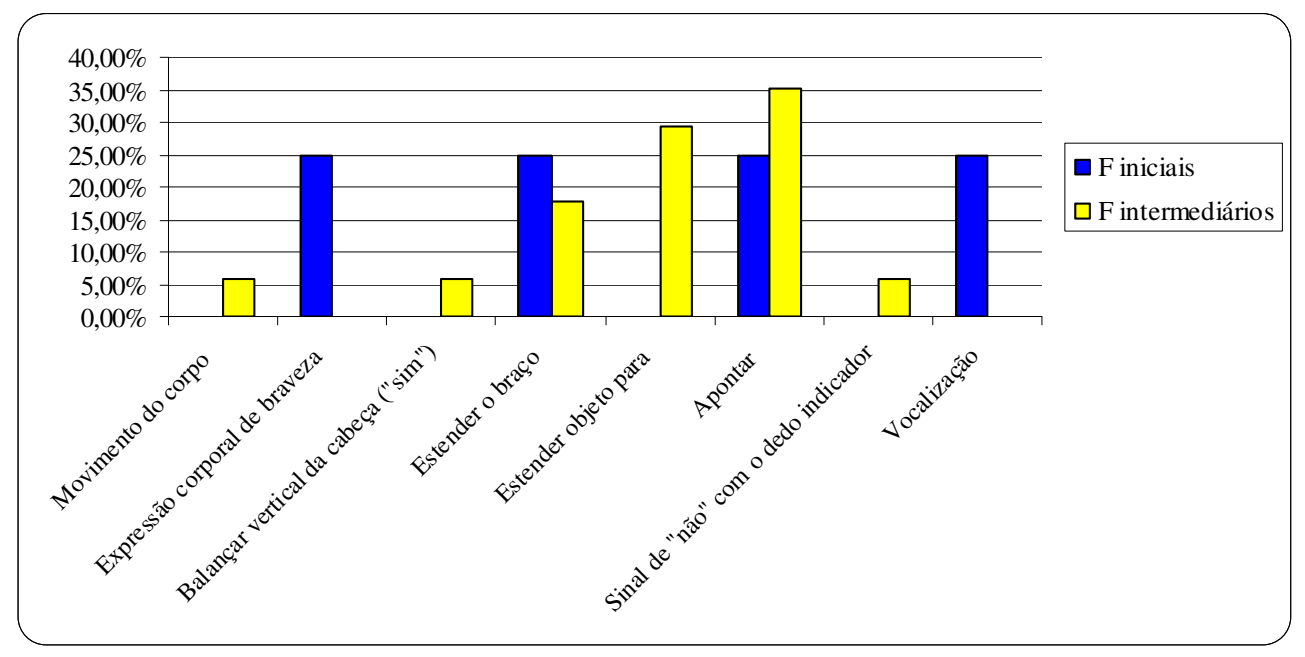

Figura 16 - Freqüências relativas das verbalizações direcionadas a adultos, para cada tipo de comportamento não-verbal indicativo de comunicação, obtidas nos focais $(F)$ iniciais (21/8/03 a 22/9/03), intermediários (25/3/04 a 28/4/04) e finais (13/10/04 a 16/11/04), das crianças A, C, Gi, H, La e S. OBS.: Não foram representados na Figura os comportamentos não-verbais que não foram acompanhados de verbalizações em nenhum período.

Albanese e Antoniotti (1998) relatam algumas pesquisas que levam à conclusão de que as crianças pequenas (de 0 a 3 anos de idade) utilizam formas diferentes de comunicação com o adulto e com outra criança. Em geral, os sinais emitidos para o adulto são para atrair sua atenção, talvez por isto "pedir" (estendendo o braço), "oferecer" (estendendo um objeto) e "apontar", tenham sido os comportamentos não-verbais acompanhados mais vezes por verbalizações. A grande frequiência de verbalizações acompanhando as expressões corporais de braveza também pode ser incluída nesta explicação, pois muitas vezes são emitidas em contextos de "birra" das crianças e não deixam de ser formas de chamar a atenção dos adultos. Parece que as verbalizações e o comportamento não-verbal se complementam, resultando 
numa comunicação mais clara. Porém, porque o número de verbalizações acompanhando comportamentos não-verbais foi menor para adultos do que para outras crianças?

Albanese e Antoniotti (op.cit.) fornecem um dado importante para responder essa pergunta: "percebeu-se que a criança que acompanha a comunicação verbal com alguns gestos, como sorrir, acariciar, pegar na mão, mostrar, etc., obtém mais respostas quando se dirige aos amigos do que a criança que não utiliza esses canais não-verbais.” (Pp. 203). De fato, a linguagem falada na faixa etária estudada ainda é precária e pode ser que as crianças sejam mais bem compreendidas em suas falas pelos adultos, que já dominam o código verbal e sabem como interpretá-lo, do que por outras crianças.

\section{4.- Análise da comunicação verbal}

O objetivo desta análise foi verificar em que contextos e com quais referências as crianças utilizaram a comunicação verbal e comparar se houve diferenças nestas variáveis entre os períodos iniciais (quatro primeiros focais), intermediários (quatro focais intermediários) e finais (quatro últimos focais). Foram considerados apenas os focais das seis crianças que fizeram parte do grupo do início ao fim do período de coleta de dados (1 ano e meio) - Alice, Gisele, Laura, Carlos, Heitor e Sílvio - totalizando 24 focais por período ou 120 minutos por período. As verbalizações das outras crianças do grupo (Meire, Bianca, Lia e Gustavo) também foram contabilizadas quando apareciam nos focais analisados.

O procedimento de análise consistiu em reunir as verbalizações registradas em classes de contexto e de referência, conforme fossem sendo necessárias. Posteriormente, as classes de contexto foram revistas e alteradas e / ou incluídas em categorias mais abrangentes com base em Corsaro (1985). Então, todas as verbalizações foram reanalisadas e adequadas à nova 
categorização. As categorias de referência relacionam-se a quem a criança dirigiu sua verbalização: ela própria (verbalização autodirigida), outra(s) criança(s), educadora, pesquisadora ou pessoa ausente (houve apenas dois casos, um em que a criança estava procurando sua mãe e outro em que a criança respondeu a uma pergunta enquanto brincava de falar ao telefone). Além disso, foram criadas categorias de referência a objetos (com o qual a criança brinca, que está com outra criança ou que está no espaço físico do local de brincadeira). Quando não se entendia para quem a criança estava falando, sua verbalização era categorizada como "referência desconhecida". Já as categorias de contexto foram elaboradas a partir de Corsaro (1985) e de acordo com as necessidades de classificação surgidas durante o processo de análise dos dados. As 14 categorias de contexto (e suas subcategorias) são:

- Imperativos - "comandos ou avisos diretos que são produzidos com forte ênfase no final da expressão e tom enfático mais elevado. A principal função do imperativo é controlar o comportamento de outros interagentes."(Corsaro, op. cit., pp. 80). As subcategorias incluídas em "imperativos" foram: repreender (relativo a regras ou proibições gerais, ou normas estabelecidas pela própria criança); impedir ou parar ação (de acordo com a vontade da criança que verbaliza); dar ordem (para) ou ordenar;

- Afirmações informativas - "produzidas para fornecer informações pertinentes à atividade ou ao assunto reconhecidos, para comentar sobre a interação em andamento ou expressar sentimentos pessoais com relação a características específicas do contexto interativo." (Corsaro, op. cit., pp. 81). As subcategorias incluídas em "afirmações declarativas" foram: descrever ação ou situação (de alguém ou algo); mostrar alguma coisa ou alguém (para); expressar sentimentos (para);

- Afirmações designativas - emitidas para indicar quem possui um determinado objeto ou para atribuir papéis sociais ou funções em brincadeiras simbólicas; 
- Questões diretivas - "são perguntas que funcionam como atos de fala diretiva." (Corsaro, op. cit., pp. 81). A subcategoria criada foi: pedir algo (para alguém). A diferença em relação aos imperativos está na entonação e forma de falar. Por exemplo: “pega a boneca!” é um imperativo quando dado com voz de comando, mas "pega a boneca?" é um pedido que direciona a ação de alguém;

- Convites para interação - categoria criada com base em "request for joint", de Corsaro (1985), que abrange todas as formas das crianças convidarem alguém para interagir. Foram consideradas como subcategorias: convidar para sentar; convidar alguém para brincar ou jogar ou mesmo quando a própria criança tenta entrar na brincadeira (ou seja, convida-se); "oferecer objeto" foi interpretado como um convite para interação (embora, em poucos casos, tenha incluído, por exemplo, oferecer alimento para um boneco com o qual a criança está brincando);

- Respostas (justificativas) - são afirmações em que a criança responde a uma pergunta, convite ou comando (imperativo) prévios feitos por outro interagente ou justifica porque agiu ou deixou de agir de determinada maneira (Corsaro, op.cit.). Foram incluídas, aqui, as subcategorias: responder pergunta de alguém (respostas abrangentes, por exemplo, em resposta à pergunta “dá um?", a criança responde "tó”); e concordar / confirmar ou discordar / negar, quando a criança limitava-se a responder de modo afirmativo ("sim") ou negativo (“não"), respectivamente;

- Pedidos de informação - "são perguntas empregadas pela pessoa que fala para obter informações dos outros interagentes, que são pertinentes à atividade em andamento" (Corsaro, op. cit., pp. 81). Foram adicionadas as subcategorias: perguntar para alguém ou para um objeto durante brincadeira simbólica; e procurar (perguntar para alguém sobre alguma coisa ou pessoa que a criança está procurando); 
- Falas nominativas - categoria criada para englobar as situações em que as crianças chamam alguém pelo nome ou dizem o nome ou apelido de uma pessoa;

- Agonismo - uma categoria muito importante em estudos etológicos e não considerada por Corsaro (1985). Compreende as subcategorias: disputar objeto com alguém; afastar alguém; defender um colega do grupo; agredir fisicamente ou por palavras; e reagir a bronca das educadoras de forma agressiva;

- Narrativas - foram inseridas nesta categoria "contar história” (para alguém) e “cantar";

• Cumprimentos - expressões do tipo “oi”, "tchau”, “olá”, “oiê" etc;

- Agradecimentos - expressões de agradecimento como "obrigada";

- Elogios - expressões utilizadas para elogiar alguém ou algum objeto. Por exemplo, "que buito!" (que bonito!);

- Falas ininteligíveis - categoria elaborada para comportar todos os episódios de verbalização em que a pesquisadora não conseguiu entender o que as crianças falavam, mas tinha certeza de que haviam emitido palavras.

É importante esclarecer que as falas das crianças foram contadas em termos de episódios de verbalização, que poderiam conter uma ou mais palavras, e que um episódio foi considerado uma única vez pela determinação do contexto predominante e da referência delimitada em cada subcategoria. Por exemplo, a pergunta "você quer pizza, Carlos?", foi classificada apenas no contexto "convite para interação" (oferecer) e na referência "outra criança”, apesar de também poder ser categorizada como um pedido de informação e com referência ao objeto com o qual a criança está. 


\section{Resultados}

Nos Apêndices 10, 11, 12 e 13 estão os resultados obtidos para os focais iniciais, intermediários e finais e a comparação entre eles quanto ao contexto e quanto à referência das verbalizações emitidas pelas crianças. Pode-se observar que nos focais iniciais (Apêndice 10) há um predomínio de verbalizações agonísticas (principalmente disputa por objeto e afastamento, dirigidas a outras crianças), falas imperativas (principalmente impedir ou parar ação, direcionadas a outras crianças) e afirmações informativas (principalmente descrever ação ou situação, tanto em relação à própria criança quanto a outras crianças). Houve um total de 65 episódios de verbalização, sendo oito de falas ininteligíveis (Tabela 14).

Nos focais intermediários (Apêndice 11), a maior parte das verbalizações foi de afirmações informativas (principalmente descrever ação ou situação da própria criança ou do objeto com o qual está), convites para interação (predomínio de "oferecer objeto" para outras crianças ou para as educadoras) e de imperativos (com maior freqüência para "dar ordem" para outras crianças). Foi registrado o maior número de episódios de verbalização entre as três fases (134) e de falas ininteligíveis (36) - Tabela 14.

Nos focais finais (Apêndice 12), houve um predomínio de episódios de verbalização do tipo "convites para interação" (principalmente, oferecer objeto para outra criança) e de afirmações informativas (novamente, com maior freqüência para descrever ação ou situação da própria criança ou do objeto com o qual está). Foram contados 130 episódios de verbalização, dos quais somente nove de falas ininteligíveis (Tabela 14).

A Tabela 14 mostra as freqüências absolutas e relativas das categorias principais de contexto das verbalizações (sem exibir os dados das subcategorias) para os três períodos de análise. 
Tabela 14 - Frequiência absoluta (Fa) e relativa (Fr - em relação ao total de episódios de verbalização de cada período de focais) das categorias de contexto dos episódios de verbalização ocorridos durante os focais iniciais (21/8/03 a 22/9/03), intermediários (25/3/04 a 28/4/04) e finais (13/10/04 a 16/11/04), das crianças A, C, Gi, H, La e S.

\begin{tabular}{|c|c|c|c|c|c|c|c|c|}
\hline \multirow[t]{2}{*}{ Contexto/focais } & \multicolumn{2}{|c|}{ Focais iniciais } & \multicolumn{2}{|c|}{ Focais intermediários } & \multicolumn{2}{|c|}{ Focais finais } & \multicolumn{2}{|c|}{ Total } \\
\hline & $\mathbf{F a}$ & Fr $(\%)$ & $\mathbf{F a}$ & $\operatorname{Fr}(\%)$ & $\mathbf{F a}$ & $\operatorname{Fr}(\%)$ & $\mathbf{F a}^{1}$ & $\operatorname{Fr}(\%)$ \\
\hline Imperativos & 11 & 16,92 & 11 & 8,21 & 7 & 5,38 & 29 & 8,81 \\
\hline Afirmações informativas & 7 & 10,77 & 18 & 13,43 & 16 & 12,31 & 41 & 12,46 \\
\hline Afirmações designativas & 1 & 1,54 & 6 & 4,48 & 8 & 6,15 & 15 & 4,56 \\
\hline Questões diretivas & 3 & 4,62 & 5 & 3,73 & 11 & 8,46 & 19 & 5,78 \\
\hline Convites para interação & 5 & 7,69 & 16 & 11,94 & 35 & 26,92 & 56 & 17,02 \\
\hline Respostas & 1 & 1,54 & 9 & 6,72 & 11 & 8,46 & 21 & 6,38 \\
\hline Pedidos de informação & 3 & 4,62 & 5 & 3,73 & 5 & 3,85 & 13 & 3,95 \\
\hline Falas nominativas & 5 & 7,69 & 10 & 7,46 & 6 & 4,62 & 21 & 6,38 \\
\hline Agonismo & 14 & 21,54 & 7 & 5,22 & 7 & 5,38 & 28 & 8,51 \\
\hline Narrativas & 1 & 1,54 & 5 & 3,73 & 11 & 8,46 & 17 & 5,17 \\
\hline Cumprimentos & 5 & 7,69 & 5 & 3,73 & 2 & 1,54 & 12 & 3,65 \\
\hline Agradecimentos & 0 & 0,00 & 0 & 0,00 & 1 & 0,77 & 1 & 0,30 \\
\hline Elogios & 1 & 1,54 & 1 & 0,75 & 1 & 0,77 & 3 & 0,91 \\
\hline Falas ininteligíveis & 8 & 12,31 & 36 & 26,87 & 9 & 6,92 & 53 & 16,12 \\
\hline Total $^{2}$ & 65 & 19,76 & 134 & 40,73 & 130 & 39,51 & 329 & 100 \\
\hline
\end{tabular}

Notas: 1) Soma dos valores absolutos de cada fase.

2) Total dos episódios de verbalização em cada fase e em relação ao total de verbalizações (soma das três fases - 329). 
Pode-se observar (Tabela 14) que "agonismo" correspondeu a 21,54\% dos episódios de verbalização nos focais iniciais, "afirmações informativas" contribuiu com 13,43\% dos episódios de verbalizações nos focais intermediários e "convites para interação" foram detectados em mais de $1 / 4$ das verbalizações dos focais finais (26,92\%). Além disso, verbalizações do tipo "agradecimento" foram detectadas apenas nos focais finais e a categoria "elogios" teve a menor freqüência relativa nas três fases de focais. Considerando-se a soma das freqüências absolutas de cada categoria obtidas nos focais iniciais, intermediários e finais, “convites para interação" (17,02\%), “falas ininteligíveis" (16,12\%) e "afirmações informativas" $(12,46 \%)$ foram as verbalizações emitidas mais vezes pelas crianças, nos períodos analisados. A Figura 17 apresenta o histograma das freqüências relativas obtidas em cada fase.

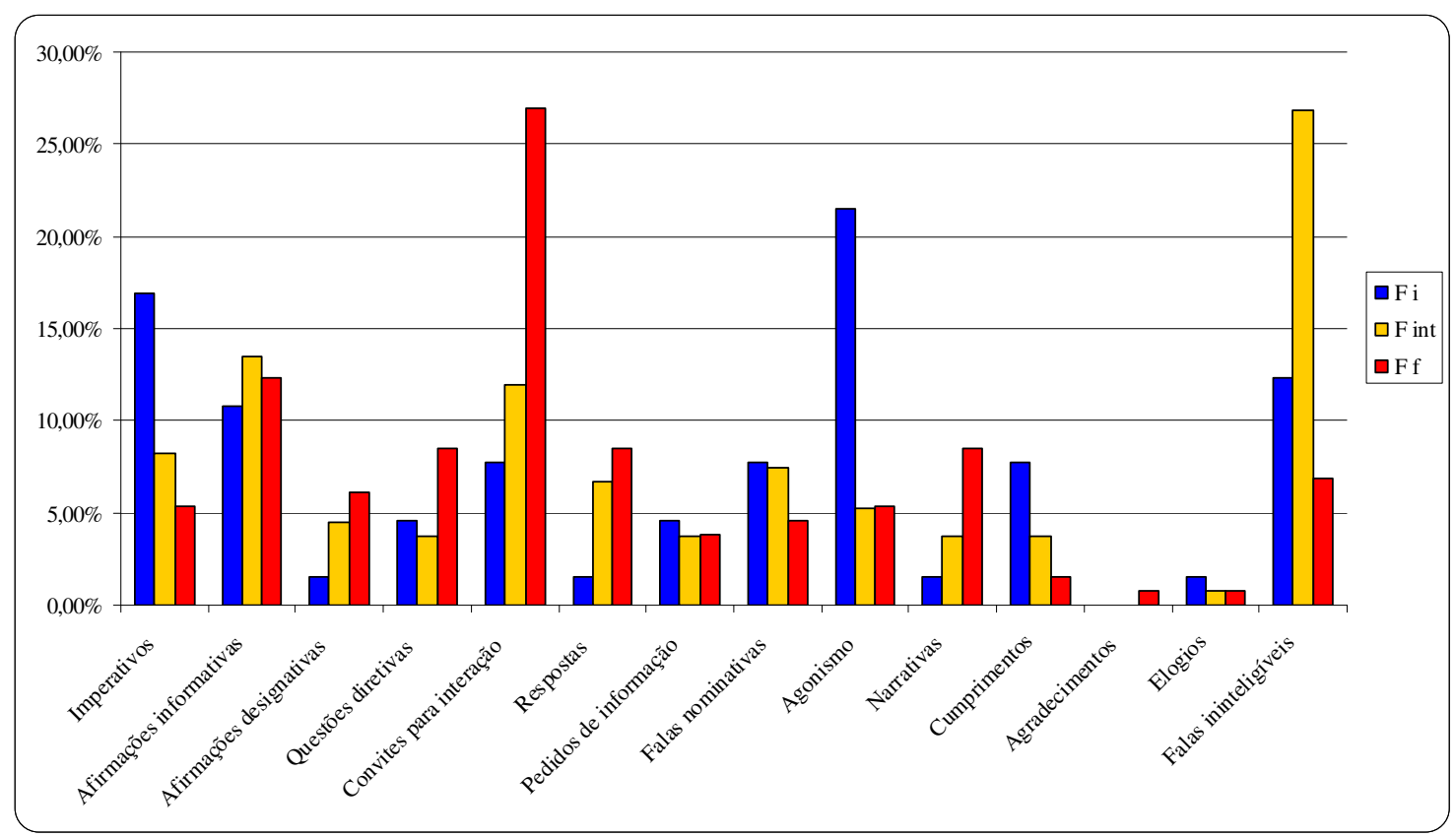

Figura 17 - Freqüências relativas das categorias de contexto dos episódios de verbalização ocorridos durante os focais iniciais ( $F$ i: 21/8/03 a 22/9/03), intermediários ( $F$ int: 25/3/04 a 28/4/04) e finais (F f: 13/10/04 a 16/11/04), das crianças A, C, Gi, H, La e S. 
A Figura 17 mostra que houve uma diminuição gradativa de verbalizações imperativas, falas nominativas e cumprimentos, dos primeiros para os últimos focais. A categoria "agonismo" teve uma acentuada diminuição de freqüência dos focais iniciais para os intermediários, que se manteve nos focais finais. Por outro lado, as frequiências de afirmações designativas, respostas e narrativas aumentaram gradualmente dos focais iniciais aos finais. Também houve um aumento na freqüência de questões diretivas, no entanto, de forma mais irregular. Destaca-se o aumento acentuado na freqüência de verbalizações correspondentes a convites para interação. Tais resultados podem ser interpretados como mudanças nas estratégias de comunicação verbal, à medida que as crianças cresceram, adquiriram habilidades sociais mais complexas e maior conhecimento entre elas no grupo (maior tempo de convivência). Parece que em vez das crianças verbalizarem ordens, nomes e cumprimentos ou falarem em contextos agonísticos, como nos focais iniciais, elas "optaram por" (ou aprenderam a) interagir com os colegas de modo mais amistoso, verbalizando "convites para interação" (focais intermediários e finais), um modo mais direto e elaborado de se relacionar com outras pessoas.

Continuando a análise da Figura 17, a frequiência de afirmações declarativas permaneceu relativamente estável, no intervalo entre 10 e $14 \%$, assim como a freqüência de pedidos de informação, entre 3 e 5\%. A freqüência de falas ininteligíveis foi duas vezes maior nos focais intermediários em relação aos focais inicias e caiu quase quatro vezes dos focais intermediários para os finais. É interessante notar que o número de falas ininteligíveis tenha sido maior nos focais em que houve mais episódios de verbalização e depois tenha diminuído acentuadamente nos focais finais, que tiveram freqüência total de episódios de verbalização quase igual à dos focais intermediários. Este resultado denota que nos focais iniciais as crianças ainda falavam pouco e, portanto, a freqüência de falas ininteligíveis era menor do que nos focais intermediários, quando as crianças já estavam falando bastante, mas, muitas 
vezes, com pouca clareza. Já nos focais finais, as crianças continuaram falando bastante, porém com maior clareza.

A análise estatística dos dados (Tabela 15) mostrou que houve associação significativa entre contextos de episódios de verbalização e períodos $\left(\chi^{2}=73,429, \mathrm{gl}=26, \mathrm{p}=0\right)$. Nos focais iniciais, as frequiências de verbalizações imperativas (resíduo ajustado $=2,6$ ) e agonísticas (resíduo ajustado = 4,2) foram maiores do que as esperadas, enquanto a frequiência de "convites para interação" foi menor do que a esperada $(-2,2)$. Nos focais intermediários, a freqüência de "convites para interação" também foi menor do que a esperada $(-2,0)$ e a de "falas ininteligíveis" foi maior do que a esperada $(4,4)$. Porém, nos focais finais, a freqüência desta última categoria foi menor do que a esperada $(-3,7)$, e as frequiências de verbalizações de “convites para interação" e de "narrativas" foram maiores do que as esperadas (resíduos ajustados iguais a, respectivamente, 3,9 e 2,2). Estes resultados confirmam as interpretações dos dados descritas nos dois parágrafos anteriores. 
Tabela 15 - Distribuição das categorias de contexto dos episódios de verbalização das crianças, nos períodos de focais iniciais (21/8/03 a 22/9/03), intermediários (25/3/04 a 28/4/04) e finais (13/10/04 a 16/11/04).

\begin{tabular}{|c|c|c|c|c|c|c|}
\hline \multicolumn{7}{|c|}{ Contexto * Período Crosstabulation } \\
\hline & & & \multicolumn{3}{|c|}{ Período } & \multirow[b]{2}{*}{ Total } \\
\hline & & & $\begin{array}{l}\text { Focais } \\
\text { iniciais }\end{array}$ & $\begin{array}{l}\text { Focais } \\
\text { intermedi } \\
\text { ários }\end{array}$ & Focais finais & \\
\hline \multirow[t]{56}{*}{ Contexto } & \multirow[t]{4}{*}{ Imperativos } & Count & 11 & 11 & 7 & 29 \\
\hline & & Expected Count & 5,7 & 11,8 & 11,5 & 29,0 \\
\hline & & $\%$ within Período & $16,9 \%$ & $8,2 \%$ & $5,4 \%$ & $8,8 \%$ \\
\hline & & Adjusted Residual & 2,6 & -3 & $-1,8$ & \\
\hline & \multirow[t]{4}{*}{ Afirm declarativas } & Count & 7 & 18 & 16 & 41 \\
\hline & & Expected Count & 8,1 & 16,7 & 16,2 & 41,0 \\
\hline & & $\%$ within Período & $10,8 \%$ & $13,4 \%$ & $12,3 \%$ & $12,5 \%$ \\
\hline & & Adjusted Residual &,- 5 & ,4 &,- 1 & \\
\hline & \multirow[t]{4}{*}{ Afirm designativas } & Count & 1 & 6 & 8 & 15 \\
\hline & & Expected Count & 3,0 & 6,1 & 5,9 & 15,0 \\
\hline & & \% within Período & $1,5 \%$ & $4,5 \%$ & $6,2 \%$ & $4,6 \%$ \\
\hline & & Adjusted Residual & $-1,3$ & -1 & 1,1 & \\
\hline & \multirow[t]{4}{*}{ Questões diretivas } & Count & 3 & 5 & 11 & 19 \\
\hline & & Expected Count & 3,8 & 7,7 & 7,5 & 19,0 \\
\hline & & \% within Período & $4,6 \%$ & $3,7 \%$ & $8,5 \%$ & $5,8 \%$ \\
\hline & & Adjusted Residual &,- 4 & $-1,3$ & 1,7 & \\
\hline & \multirow[t]{4}{*}{ Convites para interação } & Count & 5 & 16 & 35 & 56 \\
\hline & & Expected Count & 11,1 & 22,8 & 22,1 & 56,0 \\
\hline & & $\%$ within Período & $7,7 \%$ & $11,9 \%$ & $26,9 \%$ & $17,0 \%$ \\
\hline & & Adjusted Residual & $-2,2$ & $-2,0$ & 3,9 & \\
\hline & \multirow[t]{4}{*}{ Respostas } & Count & 1 & 9 & 11 & 21 \\
\hline & & Expected Count & 4,1 & 8,6 & 8,3 & 21,0 \\
\hline & & \% within Período & $1,5 \%$ & $6,7 \%$ & $8,5 \%$ & $6,4 \%$ \\
\hline & & Adjusted Residual & $-1,8$ & ,2 & 1,2 & \\
\hline & \multirow[t]{4}{*}{ Pedidos de informação } & Count & 3 & 5 & 5 & 13 \\
\hline & & Expected Count & 2,6 & 5,3 & 5,1 & 13,0 \\
\hline & & $\%$ within Período & $4,6 \%$ & $3,7 \%$ & $3,8 \%$ & $4,0 \%$ \\
\hline & & Adjusted Residual & ,3 &,- 2 &,- 1 & \\
\hline & \multirow[t]{4}{*}{ Falas nominativas } & Count & 5 & 10 & 6 & 21 \\
\hline & & Expected Count & 4,1 & 8,6 & 8,3 & 21,0 \\
\hline & & \% within Período & $7,7 \%$ & $7,5 \%$ & $4,6 \%$ & $6,4 \%$ \\
\hline & & Adjusted Residual &, 5 & ,7 & $-1,1$ & \\
\hline & \multirow[t]{4}{*}{ Agonismo } & Count & 14 & 7 & 7 & 28 \\
\hline & & Expected Count & 5,5 & 11,4 & 11,1 & 28,0 \\
\hline & & $\%$ within Período & $21,5 \%$ & $5,2 \%$ & $5,4 \%$ & $8,5 \%$ \\
\hline & & Adjusted Residual & 4,2 & $-1,8$ & $-1,6$ & \\
\hline & \multirow[t]{4}{*}{ Narrativas } & Count & 1 & 5 & 11 & 17 \\
\hline & & Expected Count & 3,4 & 6,9 & 6,7 & 17,0 \\
\hline & & \% within Período & $1,5 \%$ & $3,7 \%$ & $8,5 \%$ & $5,2 \%$ \\
\hline & & Adjusted Residual & $-1,5$ & $-1,0$ & 2,2 & \\
\hline & \multirow[t]{4}{*}{ Cumprimentos } & Count & 5 & 5 & 2 & 12 \\
\hline & & Expected Count & 2,4 & 4,9 & 4,7 & 12,0 \\
\hline & & \% within Período & $7,7 \%$ & $3,7 \%$ & $1,5 \%$ & $3,6 \%$ \\
\hline & & Adjusted Residual & 1,9 & , 1 & $-1,6$ & \\
\hline & Agradecimentos & Count & 0 & 0 & 1 & 1 \\
\hline & & Expected Count & ,2 & ,4 & ,4 & 1,0 \\
\hline & & \% within Período &, $0 \%$ &, $0 \%$ &, $8 \%$ &, $3 \%$ \\
\hline & & Adjusted Residual &,- 5 &,- 8 & 1,2 & \\
\hline & Elogios & Count & 1 & 1 & 1 & 3 \\
\hline & & Expected Count & ,6 & 1,2 & 1,2 & 3,0 \\
\hline & & \% within Período & $1,5 \%$ & ,7\% & ,8\% & ,9\% \\
\hline & & Adjusted Residual &, 6 &,- 3 &,- 2 & \\
\hline & Falas ininteligíveis & Count & 8 & 36 & 9 & 53 \\
\hline & & Expected Count & 10,5 & 21,6 & 20,9 & 53,0 \\
\hline & & \% within Período & $12,3 \%$ & $26,9 \%$ & $6,9 \%$ & $16,1 \%$ \\
\hline & & Adjusted Residual &,- 9 & 4,4 & $-3,7$ & \\
\hline Total & & Count & 65 & 134 & 130 & 329 \\
\hline & & Expected Count & 65,0 & 134,0 & 130,0 & 329,0 \\
\hline & & $\%$ within Período & $100,0 \%$ & $100,0 \%$ & $100,0 \%$ & $100,0 \%$ \\
\hline
\end{tabular}


Os resultados obtidos para os focais inicias estão, em parte, de acordo com as considerações de Tomasello (2003) de que as crianças de todas as culturas aprendem e usam seus primeiros símbolos lingüísticos de modo imperativo e declarativo.

Quanto às referências das verbalizações emitidas pelas crianças, a Tabela 16 e a Figura 18 mostram que em todas as fases as crianças verbalizaram mais para outras crianças do que para outras pessoas ou para objetos, contudo nos focais intermediários a freqüência relativa de verbalização para outras crianças foi menor do que nos focais inicias e nos finais. Isto pode ser devido às crianças terem verbalizado mais, nessa fase, para as educadoras, para os objetos com os quais estavam brincando ou que outras crianças estavam brincando (brincadeira simbólica) e por suas falas terem sido mais difíceis de entender (maior índice de falas ininteligíveis e de referência desconhecida nos focais intermediários). A presença da brincadeira simbólica pode ser reconhecida nas verbalizações das subcategorias “dar ordem”, “descrever ação ou situação", "indicar quem possui”, "atribuir papel ou função”, "oferecer” e “cantar", quando dirigidas a um objeto (o que ocorreu com grande freqüência nos focais intermediários). Uma explicação adicional é que as crianças, ao aumentarem suas freqüências de verbalizações durante o desenvolvimento, privilegiem inicialmente utilizar a comunicação verbal com adultos, enquanto continuam a se comunicar principalmente pelo modo não-verbal com coetâneos. Esta hipótese poderia ser corroborada com a afirmação de Brannigan e Humphries (1981) de que, embora crianças de 3 a 4 anos utilizem a fala para se comunicar com adultos, elas ainda a usam pouco durante brincadeiras com os colegas da mesma idade. No entanto, a alta freqüência de verbalizações direcionadas a outras crianças nos focais finais indica que talvez as crianças se comuniquem verbalmente entre si mais cedo do que os autores afirmaram. 
Tabela 16 - Freqüência absoluta $(\mathrm{Fa})$ e relativa $(\mathrm{Fr}$ - em relação ao total de episódios de verbalização de cada período de focais) das categorias de referência dos episódios de verbalização ocorridos durante os focais iniciais (21/8/03 a 22/9/03), intermediários (25/3/04 a 28/4/04) e finais (13/10/04 a 16/11/04), das crianças A, C, Gi, H, La e S.

\begin{tabular}{|c|c|c|c|c|c|}
\hline Referência / focais & & Iniciais & Intermediários & Finais & Total $^{1}$ \\
\hline \multirow{2}{*}{ Própria criança } & $\mathbf{F a}$ & 6 & 9 & 13 & 28 \\
\hline & $\operatorname{Fr}(\%)$ & 9,23 & 6,72 & 10,00 & 8,51 \\
\hline \multirow{2}{*}{ Outra $(s)$ criança $(s)$} & $\mathbf{F a}$ & 43 & 52 & 88 & 183 \\
\hline & $\operatorname{Fr}(\%)$ & 66,15 & 38,81 & 67,69 & 55,62 \\
\hline \multirow{2}{*}{$\begin{array}{l}\text { Objeto com o qual } \\
\text { está }\end{array}$} & Fa & 1 & 22 & 17 & 40 \\
\hline & $\operatorname{Fr}(\%)$ & 1,54 & 16,42 & 13,08 & 12,16 \\
\hline \multirow{2}{*}{$\begin{array}{l}\text { Objeto que está com } \\
\text { outra criança }\end{array}$} & Fa & 0 & 7 & 0 & 7 \\
\hline & $\operatorname{Fr}(\%)$ & 0,00 & 5,22 & 0,00 & 2,13 \\
\hline \multirow{2}{*}{ Objeto no espaço } & $\mathbf{F a}$ & 2 & 3 & 0 & 5 \\
\hline & $\operatorname{Fr}(\%)$ & 3,08 & 2,24 & 0,00 & 1,52 \\
\hline \multirow{2}{*}{ Educadora } & Fa & 6 & 27 & 8 & 41 \\
\hline & $\operatorname{Fr}(\%)$ & 9,23 & 20,15 & 6,15 & 12,46 \\
\hline \multirow{2}{*}{ Pesquisadora } & $\mathbf{F a}$ & 1 & 2 & 0 & 3 \\
\hline & $\operatorname{Fr}(\%)$ & 1,54 & 1,49 & 0,00 & 0,91 \\
\hline \multirow{2}{*}{$\begin{array}{l}\text { Referência } \\
\text { desconhecida }\end{array}$} & Fa & 4 & 12 & 4 & 20 \\
\hline & $\operatorname{Fr}(\%)$ & 6,15 & 8,96 & 3,08 & 6,08 \\
\hline \multirow{2}{*}{ Pessoa ausente } & Fa & 2 & 0 & 0 & 2 \\
\hline & $\operatorname{Fr}(\%)$ & 3,08 & 0,00 & 0,00 & 0,61 \\
\hline
\end{tabular}

Notas: 1) Soma dos valores absolutos de cada fase.

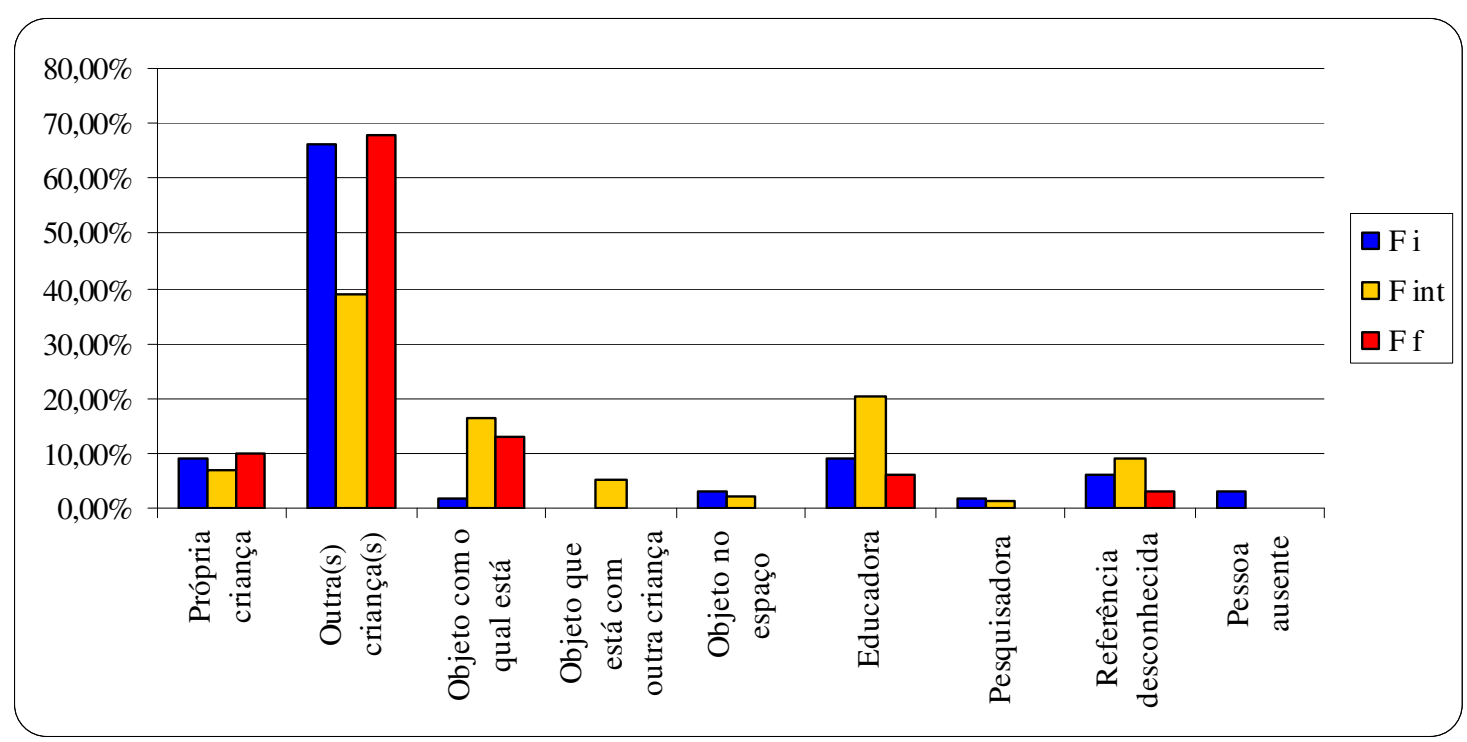

Figura 18 - Frequiências relativas das categorias de referência dos episódios de verbalização ocorridos durante os focais iniciais ( $\mathrm{F}$ i: 21/8/03 a 22/9/03), intermediários ( $\mathrm{F}$ int: 25/3/04 a 28/4/04) e finais (F f: 13/10/04 a 16/11/04), das crianças A, C, Gi, H, La e S. 
Além disso, as freqüências das categorias "própria criança" e "referência desconhecida" mantiveram-se praticamente estáveis (entre 6 e $10 \%$ e 3 e 9\%, respectivamente), entre os três períodos, e as categorias "objeto que está com outra criança", “objeto no espaço", "pesquisadora" e "pessoa ausente” apareceram pouco como referência nas verbalizações das crianças. Considerando-se a soma dos valores absolutos de cada fase ("total”, na Tabela 16), as referências mais freqüentes das verbalizações das crianças foram “outra(s) criança(s)" (55,62\%), "educadora" $(12,46 \%)$ e "objeto com o qual está" $(12,16 \%)$. Neste ponto, há dois fatores que precisam ser levados em conta: o primeiro é que os focais ocorriam, propositalmente, numa situação de brincadeira "livre" entre as crianças, em que as educadoras foram instruídas a interferirem o mínimo possível. Esta condição foi relevante devido ao objetivo do trabalho que era estudar a interação criança-criança. Todavia, as educadoras permaneciam sempre nos locais onde eram realizadas as sessões e as crianças podiam recorrer a elas sempre que quisessem ou necessitassem. $O$ segundo fator a ser discutido relaciona-se ao modo como foram construídas as subcategorias de contexto, que poderiam ter mais de uma referência, mas, para evitar que um episódio de verbalização fosse contabilizado mais de uma vez, deu-se preferência à pessoa para quem a criança falava e não sobre o que ela falava. Por exemplo, em "responder pergunta (de)", foi considerado apenas para quem a criança respondia e não sobre o que ela falava (responder sobre algo). E as categorias, em geral (como "imperativos", "questões diretivas" e "agonismo"), tendiam a ter como referência pessoas e não objetos. Portanto, o mais importante é analisar separadamente as categorias de referência correspondestes a pessoas e aquelas correspondentes a objetos, uma vez que foi dado um pêso diferente para os dois tipos de categorias.

Submetendo-se os valores das categorias de referência das verbalizações das crianças à análise estatística (Tabela 17) obteve-se associação significativa entre períodos e referências $\left(\chi^{2}=59,059, \mathrm{gl}=16, \mathrm{p}=0\right)$. Nos focais iniciais, a frequiência de verbalizações para o objeto 
com o qual a criança estava foi menor do que a esperada $(-2,9)$ e a de verbalizações para uma pessoa ausente foi maior do que a esperada $(2,9)$. Nos focais intermediários, as freqüências de verbalizações para o objeto com o qual a criança estava e para o objeto que estava com outra criança foram maiores do que as esperadas (resíduos ajustados iguais a, respectivamente, 2,0 e 3,2), assim como a freqüência de verbalizações dirigidas às educadoras (3,5). Neste mesmo período, a freqüência de verbalizações para outras crianças foi menor do que a esperada ($5,1)$. Nos focais finais, a frequiência desta mesma categoria foi maior do que a esperada $(3,6)$, enquanto as freqüências de verbalizações para o objeto que estava com outra criança e para as educadoras foram menores do que as esperadas (resíduos ajustados iguais a, -2,2 e -2,8 respectivamente).

A Figura 19 mostra um histograma com a comparação da freqûencia total de episódios de verbalização obtida em cada período.

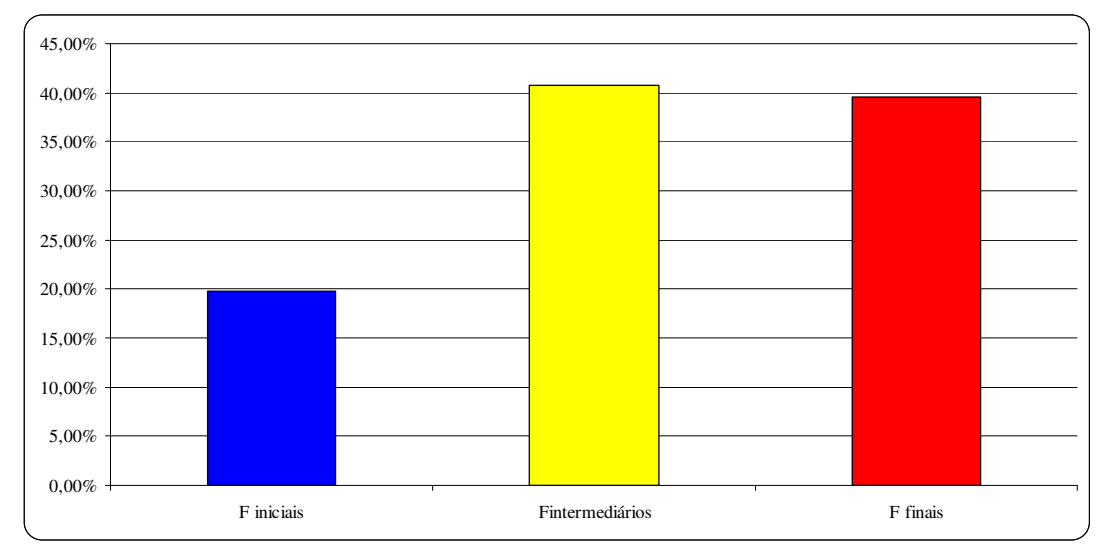

Figura 19 - Freqüências relativas do total de episódios de verbalização ocorridos durante os focais iniciais ( $F$ iniciais: 21/8/03 a 22/9/03), intermediários ( $F$ intermediários: 25/3/04 a 28/4/04) e finais (F finais: 13/10/04 a 16/11/04), das crianças A, C, Gi, H, La e S.

Aplicando-se o teste do Qui Quadrado, observou-se que houve diferença significativa dos totais de verbalizações entre os três períodos $\left(\chi^{2}=27,362, \mathrm{gl}=2, \mathrm{p}=0\right)$. Ou seja, do período inicial para o intermediário e o final as crianças aumentaram significativamente sua freqüência de verbalizações. 
Tabela 17 - Distribuição das categorias de referência dos episódios de verbalização das crianças, nos períodos de focais iniciais (21/8/03 a 22/9/03), intermediários (25/3/04 a 28/4/04) e finais (13/10/04 a 16/11/04).

\begin{tabular}{|c|c|c|c|c|c|c|}
\hline \multicolumn{7}{|c|}{ Referência * Período Crosstabulation } \\
\hline & & & \multicolumn{3}{|c|}{ Período } & \multirow[b]{2}{*}{ Total } \\
\hline & & & $\begin{array}{l}\text { Focais } \\
\text { iniciais }\end{array}$ & $\begin{array}{l}\text { Focais } \\
\text { intermedi } \\
\text { ários }\end{array}$ & Focais finais & \\
\hline \multirow[t]{36}{*}{ Referência } & \multirow[t]{4}{*}{ Própria criança } & Count & 6 & 9 & 13 & 28 \\
\hline & & Expected Count & 5,5 & 11,4 & 11,1 & 28,0 \\
\hline & & $\%$ within Período & $9,2 \%$ & $6,7 \%$ & $10,0 \%$ & $8,5 \%$ \\
\hline & & Adjusted Residual & ,2 & $-1,0$ & ,8 & \\
\hline & \multirow[t]{4}{*}{ Outra(s) criança(s) } & Count & 43 & 52 & 88 & 183 \\
\hline & & Expected Count & 36,2 & 74,5 & 72,3 & 183,0 \\
\hline & & \% within Período & $66,2 \%$ & $38,8 \%$ & $67,7 \%$ & $55,6 \%$ \\
\hline & & Adjusted Residual & 1,9 & $-5,1$ & 3,6 & \\
\hline & \multirow[t]{4}{*}{ Objeto com o qual está } & Count & 1 & 22 & 17 & 40 \\
\hline & & Expected Count & 7,9 & 16,3 & 15,8 & 40,0 \\
\hline & & \% within Período & $1,5 \%$ & $16,4 \%$ & $13,1 \%$ & $12,2 \%$ \\
\hline & & Adjusted Residual & $-2,9$ & 2,0 & ,4 & \\
\hline & \multirow[t]{4}{*}{ Objeto com outra criança } & Count & 0 & 7 & 0 & 7 \\
\hline & & Expected Count & 1,4 & 2,9 & 2,8 & 7,0 \\
\hline & & \% within Período &, $0 \%$ & $5,2 \%$ &, $0 \%$ & $2,1 \%$ \\
\hline & & Adjusted Residual & $-1,3$ & 3,2 & $-2,2$ & \\
\hline & \multirow[t]{4}{*}{ Objeto no espaço } & Count & 2 & 3 & 0 & 5 \\
\hline & & Expected Count & 1,0 & 2,0 & 2,0 & 5,0 \\
\hline & & \% within Período & $3,1 \%$ & $2,2 \%$ &, $0 \%$ & $1,5 \%$ \\
\hline & & Adjusted Residual & 1,1 & ,9 & $-1,8$ & \\
\hline & \multirow[t]{4}{*}{ Educadora } & Count & 6 & 27 & 8 & 41 \\
\hline & & Expected Count & 8,1 & 16,7 & 16,2 & 41,0 \\
\hline & & \% within Período & $9,2 \%$ & $20,1 \%$ & $6,2 \%$ & $12,5 \%$ \\
\hline & & Adjusted Residual &,- 9 & 3,5 & $-2,8$ & \\
\hline & \multirow[t]{4}{*}{ Pesquisadora } & Count & 1 & 2 & 0 & 3 \\
\hline & & Expected Count & ,6 & 1,2 & 1,2 & 3,0 \\
\hline & & $\%$ within Período & $1,5 \%$ & $1,5 \%$ &, $0 \%$ &, $9 \%$ \\
\hline & & Adjusted Residual &, 6 &, 9 & $-1,4$ & \\
\hline & \multirow[t]{4}{*}{ Referência desconhecida } & Count & 4 & 12 & 4 & 20 \\
\hline & & Expected Count & 4,0 & 8,1 & 7,9 & 20,0 \\
\hline & & $\%$ within Período & $6,2 \%$ & $9,0 \%$ & $3,1 \%$ & $6,1 \%$ \\
\hline & & Adjusted Residual & 0 & 1,8 & $-1,8$ & \\
\hline & \multirow[t]{4}{*}{ Pessoa ausente } & Count & 2 & 0 & 0 & 2 \\
\hline & & Expected Count & ,4 &, 8 & ,8 & 2,0 \\
\hline & & \% within Período & $3,1 \%$ &, $0 \%$ &, $0 \%$ & $6 \%$ \\
\hline & & Adjusted Residual & 2,9 & $-1,2$ & $-1,1$ & \\
\hline \multirow{3}{*}{\multicolumn{2}{|c|}{ Total }} & Count & 65 & 134 & 130 & 329 \\
\hline & & Expected Count & 65,0 & 134,0 & 130,0 & 329,0 \\
\hline & & $\%$ within Período & $100,0 \%$ & $100,0 \%$ & $100,0 \%$ & $100,0 \%$ \\
\hline
\end{tabular}

\section{5.- Persistência de significados construídos no grupo}

A persistência de significados foi investigada em duas dimensões: recorrência de relações preferenciais entre as crianças, e recorrência de brincadeiras, modos de utilização de objetos e enredos lúdicos em uma mesma situação e em situações posteriores. Partiu-se da 
premissa de que a persistência de significados está na raiz do conceito de cultura em geral, e de cultura de pares de idade em particular. Para verificar a ocorrência de persistência de significados construídos no grupo e, com isto, a existência de microcultura, os focais do último semestre (julho a dezembro de 2004), a última sessão de cada díade antes das sessões conjuntas (agosto a dezembro de 2004) e as duas sessões conjuntas foram analisadas quanto à presença e os tipos de brincadeiras, bem como os objetos, as crianças e a forma de comunicação (verbal ou não-verbal) nelas envolvidos. Foram consideradas todas as crianças (com exceção de Meire, que não fazia mais parte do grupo), que tinham entre 16 e 33 meses de idade no início da coleta dos dados e entre 20 e 37 meses no final.

A idéia inicial era classificar as brindadeiras de acordo com Morais e Otta (2003), Gosso e Otta (2003) e Parker (1984) - tal como aparece no item 5.6. Porém, uma análise preliminar indicou que este tipo de classificação das brincadeiras era inadequado para capturar a natureza do fenômeno que se deseja analisar. Portando, buscou-se elaborar categorias semânticas que pudessem evidenciar melhor a persistência de significados lúdicos construídos no grupo. Primeiramente, para as sessões de observação em situação de atividade lúdica livre, os objetos com os quais se observou as crianças brincando foram separados em categorias razoavelmente amplas e os modos como as crianças utilizaram estes objetos foram colocados numa tabela de acordo com sua função usual (comum) ou diferente desta (Apêndice 14). Esta tabela também traz informações sobre o sujeito-focal que se observou efetuando cada tipo de ação com os objetos, bem como a freqüência de uso dos objetos por criança e no total (conforme o sexo do sujeito). Em termos de análise quantitativa, não foram consideradas as crianças com as quais o sujeito-focal estava brincando, em parte porque, para fins de classificação, levou-se em conta o tema principal que definia a brincadeira, evitando-se, com isto, que uma mesma brincadeira fosse contada mais de uma vez quando houvesse a participação de mais de um tipo de objeto. Para as sessões de observação em situação semicontrolada (duplas e 
conjuntas), foram construídas tabelas semelhantes à anterior, porém já se considerou a brincadeira conjunta entre as crianças e os episódios de imitação detectados (Apêndices15, 16 e 17). Posteriormente, as tabelas dos focais, das duplas e das duas sessões conjuntas foram comparadas, a fim de verificar modos de utilização de objetos parecidos ou iguais, brincadeiras e enredos lúdicos recorrentes entre elas.

É interessante notar que essa forma de trabalhar os dados permite uma análise quantitativa, porém desfavorece uma análise qualitativa, pois se perde a noção do processo de construção e transformação das brincadeiras. Por isto, alguns episódios serão destacados e acompanhados de maneira qualitativa.

\section{Resultados}

Os sociogramas referentes às observações em situação de atividade lúdica livre do último semestre e aqueles referentes às duas sessões conjuntas estão nas Figuras 20, 21 e 22.

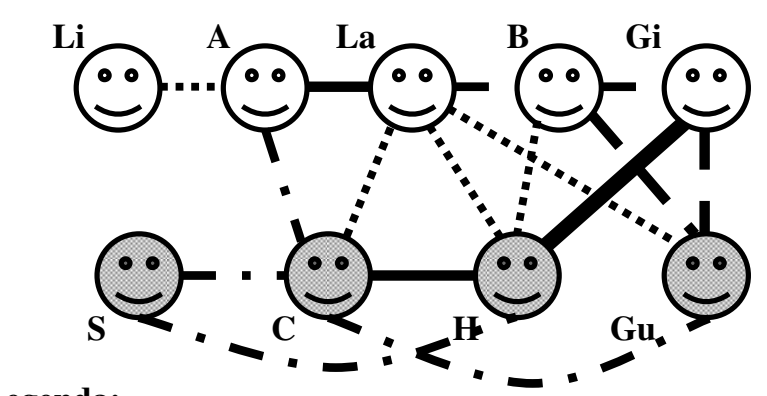

Legenda:
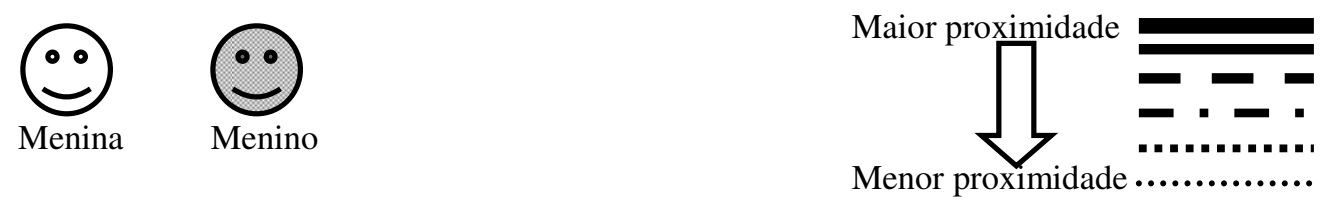

Figura 20 - Sociograma obtido a partir dos valores de proximidade provenientes dos registros por varredura realizados no início e no fim das sessões de observações em situação lúdica livre, no período de 8/7/04 a 16/11/04 (32 scans). Foram representadas apenas as proximidades dos pares cujos valores eram maiores do que a média $(\mathrm{M}=2,5)$. 
I)

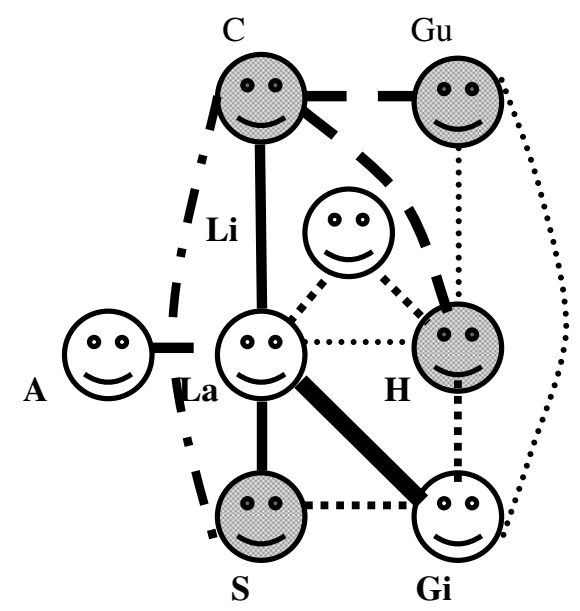

II)

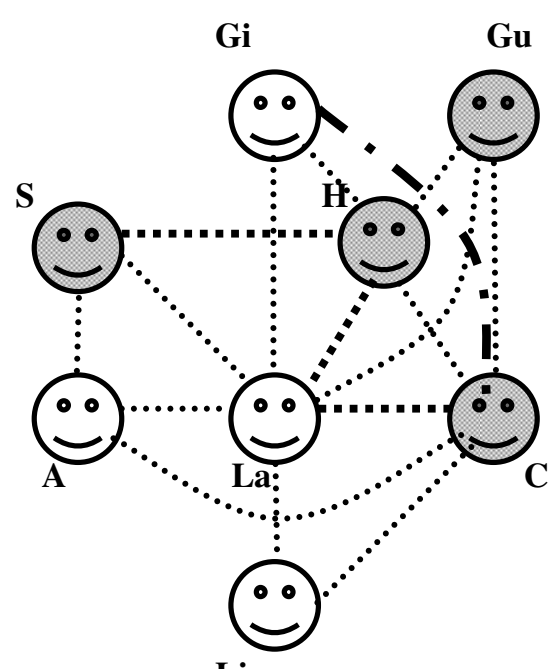

Li

Legenda: igual à da Figura 20.

Figura 21 - Sociogramas obtidos a partir do registro (I) de todas as ocorrências de proximidade (20 minutos, exceto tempo dos scans) durante a primeira sessão conjunta (16/12/04, manhã) e (II) das proximidades verificadas nos scans realizados na mesma sessão. Foram representadas apenas as proximidades dos pares cujos valores eram maiores do que a média $(\mathrm{M}=5,7)$. B faltou, A esteve ausente durante quase 10 minutos. I)

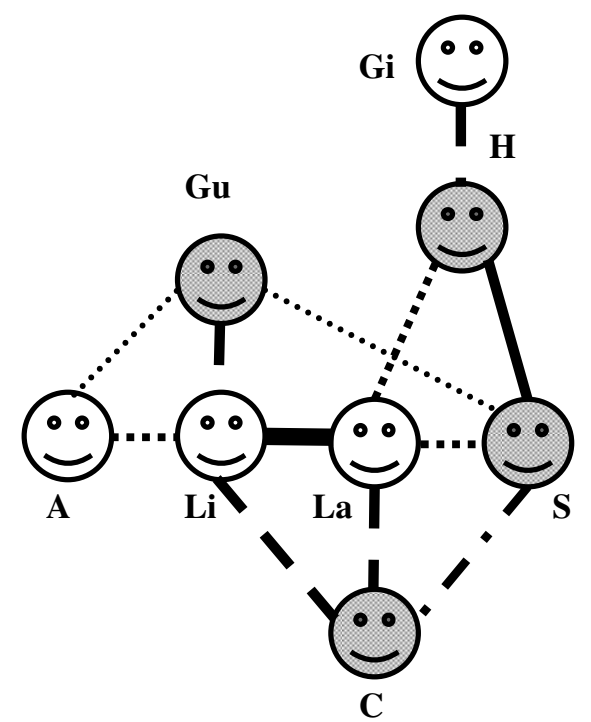


II)
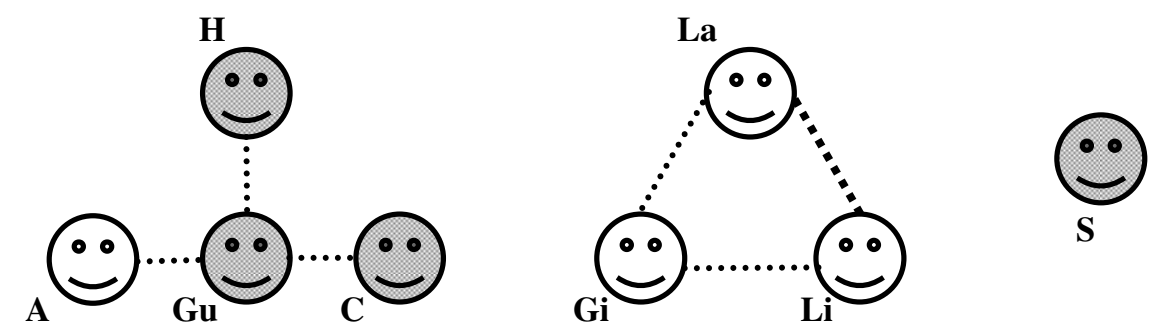

Legenda: igual à da Figura 20.

Figura 22 - Sociogramas obtidos a partir do registro (I) de todas as ocorrências de proximidade (20 minutos, exceto tempo dos scans) durante a segunda sessão conjunta (16/12/04, tarde) e (II) das proximidades verificadas nos scans realizados na mesma sessão. Foram representadas apenas as proximidades dos pares cujos valores eram maiores do que a média $(M=6,0)$. B faltou.

A Figura 20 mostra que, ao longo do $3^{\circ}$ semestre de observações, a relação mais forte em termos de proximidade foi aquela entre Gisele e Heitor, seguida pela de Alice e Laura, e a de Carlos e Heitor. Já na primeira sessão conjunta (todas as ocorrências), as relações mais fortes foram entre Gisele e Laura, seguida pela de Carlos e Laura, e a de Laura e Sílvio (Figura 21.I). Enquanto na segunda sessão conjunta (todas as ocorrências), Laura e Lia, Heitor e Sílvio foram os pares com maiores valores de proximidade (Figura 22.I). Portanto, Laura estava incluída em cinco dos oito pares com maior proximidade - Heitor estava incluído em três; Carlos, Gisele e Sílvio em dois e Lia em apenas um. Em termos de persistência das relações preferenciais, os resultados indicam que houve persistência nas relações: CarlosLaura, Carlos-Sílvio, Gisele-Heitor, Heitor-Laura (Tabela 18). Embora não tenha sido registrada uma freqüência de proximidade acima da média nas três situações (atividade lúdica livre, conjuntas 1 e 2), os seguintes pares também tiveram uma tendência à persistência: A-La, C-Gu, C-H, Gi-Gu, H-S, La-Li e La-S (estes dois últimos pares, somente nas sessões conjuntas). 
Tabela 18 - Número de vezes (acima da média) que cada par de crianças foi visto próximo nos registros feitos por varredura (32 scans) nas sessões de observação de atividade lúdica livre (8/7/04 a 16/11/04) e durante as sessões conjuntas (todas as ocorrências, excluindo observações feitas por varredura; 16/12/04). (Em destaque, as freqüências de proximidade que se mantiveram acima da média nas três situações).

\begin{tabular}{|c|c|c|c|}
\hline Pares & $\begin{array}{c}\text { Atividade lúdica } \\
\text { livre }\end{array}$ & Conjunta 1 & Conjunta 2 \\
\hline A-C & 4 & -- & -- \\
\hline A-Gi & 3 & -- & -- \\
\hline A-Gu & -- & -- & 7 \\
\hline A-La & 6 & 8 & -- \\
\hline A-Li & 3 & -- & 8 \\
\hline B-Gi & 4 & -- & -- \\
\hline B-Gu & 5 & -- & -- \\
\hline B-H & 3 & -- & -- \\
\hline C-Gu & 4 & 9 & -- \\
\hline C-H & 6 & 9 & -- \\
\hline C-La & 3 & 10 & 10 \\
\hline C-Li & -- & -- & 10 \\
\hline C-S & 4 & 8 & 9 \\
\hline Gi-Gu & 5 & 6 & -- \\
\hline Gi-H & 7 & 7 & 10 \\
\hline Gi-La & -- & 11 & -- \\
\hline Gi-S & -- & 7 & -- \\
\hline Gu-H & -- & 6 & -- \\
\hline Gu-La & 3 & -- & -- \\
\hline Gu-Li & -- & -- & 10 \\
\hline Gu-S & -- & -- & 7 \\
\hline H-La & 3 & 6 & 8 \\
\hline H-Li & -- & 7 & -- \\
\hline H-S & 4 & -- & 12 \\
\hline La-Li & -- & 7 & 18 \\
\hline La-S & -- & 10 & 8 \\
\hline
\end{tabular}

Os registros feitos por varredura durante a primeira sessão conjunta apontam resultados semelhantes àqueles discutidos até o momento. A relação mais forte foi aquela entre Carlos e Gisele (somente este par não apareceu nas medições anteriores), seguida pela de Carlos e Laura, Heitor e Laura e Heitor e Sílvio. Já os dados referentes aos scans da segunda sessão conjunta, são diferentes porque apresentam dois grupinhos separados e uma criança (Sílvio) que não foi vista com ninguém. No entanto, foram feitos apenas dois scans, obtendo-se, assim, uma amostra muito pequena, que talvez não reflita tão bem a realidade 
quanto as outras medições. Laura e Lia foram as duas crianças que estavam próximas nos dois scans da segunda sessão conjunta.

Do que foi exposto, pode-se concluir que houve persistência de relações preferenciais para quatro díades: C-La; C-S; Gi-H; H-La.

Quanto à análise das brincadeiras de acordo com a freqüência de uso de cada uma das categorias de objetos nas sessões de observação de atividade lúdica livre, chama a atenção a diferença encontrada entre meninas (f) e meninos $(\mathrm{m})$ para: bonecas $(\mathrm{f}=17 ; \mathrm{m}=6)$; carrinhos $(f=14 ; m=21)$; ferro de passar roupas $(f=6 ; m=0)$; utensílios de cozinha $(f=16 ; m=26)$. Estes resultados estão de acordo com tendências macroculturais das meninas brincarem mais de boneca do que os meninos e destes brincarem mais de carrinho do que as meninas, e evidenciam que isto já ocorre aos 2 anos de idade. De fato, ainda hoje é habitual adultos darem, em geral, bonecas para as meninas e carrinhos para os meninos brincarem, desde a mais tenra idade. Além disso, parece que a atividade de passar roupas ficou restrita às meninas. Embora os meninos tenham brincado mais com utensílios de cozinha do que as meninas, pode-se supor que esta diferença quantitativa se dá porque eles utilizaram os utensílios de formas incomuns, além das habituais, como batendo um objeto no outro ou utilizando-os para cantar parabéns .

O Apêndice 18 mostra os modos de utilização de categorias de objetos e brincadeiras que foram iguais ou semelhantes entre os quatro tipos de sessões (focais, duplas, conjunta 1 e conjunta 2). Pode-se observar que a maior parte das formas de utilização dos objetos considerados como sendo de uma mesma categoria (e das brincadeiras que suscitaram) que foram equivalentes nas diferentes sessões são formas de uso comuns e esperadas para esses objetos. A única forma realmente inusitada para o uso de um objeto foi: passar ou esfregar peças de plástico ou de madeira no corpo de outra criança, durante brincadeira de médico. Em relação ao período analisado - agosto a dezembro de 2004 - esta brincadeira apareceu pela 
primeira vez na dupla formada por Gisele e Laura. Havia um contexto para o surgimento dela, pois o "kit médico" (estetoscópio, seringa e potinho de medicamento) estava disponível para as crianças brincarem ( $4^{\mathrm{a}}$ sessão de duplas). Um trecho da transcrição da sessão de Gi-La $(12 / 8 / 04)$ pode ser visto abaixo:

\section{"Brincando de médico":}

La (f, 32 meses) propõe de brincarem de médico: pega peças de madeira e diz repetidas vezes que ela é o médico e Gi (f, 33 meses) responde "então, tá!", mas La segura as duas seringas. Gi aceita ser a paciente, deita-se no chão, mas La diz que ela é o médico e deita-se no chão (larga as peças) com a barriga para baixo. Aí, Gi diz "então eu sou o médico!?!"; dá "remédio" na boca de La com a seringa. Então, pergunta o que La quer e ela toca na peça vermelha, porém não diz o que é. Gi esfrega a peça na lombar de La, depois pergunta para ela "o que é isso, Laura?" primeiro La diz que é sabonete e depois que é para dor de cabeça. Gi passa a peça no pescoço de La e volta a passá-la na lombar. La senta-se, Gi pega outra peça e passa nas pernas de La. (...)

O episódio acima mostra como foi sendo construído e compartilhado o significado da peça de madeira na brincadeira de médico. Este significado persiste por algum tempo, pois Gisele continua a passar a peça no corpo de Laura.

Já nas sessões de observação de atividade lúdica livre (focais), a brincadeira aparece no início de setembro (8/9/04), ao longo dos focais de Alice, Heitor e Sílvio, e começa um pouco diferente, embora também com Laura. Os excertos dos focais são apresentados em seguida:

Focal de Alice

La (f, 33 meses) aproxima seu rosto do da boneca que está com A (f, 30 meses) e pergunta para A "é bonita?". A responde "é". La fala "ela morreu". A concorda "é”. La diz "porque ...". A completa "porque ela era pra naná” - cada uma segura uma mão da boneca. Depois La pega dois pinos de madeira e "trata" da boneca (passa-os no corpo dela). Então, La fala "tá viva!". E A pergunta "tá viva?". Depois La tenta levantar a boneca, que estava deitada, mas A não deixa e La completa "ela não morreu”. 
Focal de Heitor

A estava brincando de médico com uma boneca grande. La deita-se ao lado dela e $H$ ( $m, 34$ meses), que estava com uma peça (de plástico) na mão, começa a passála na barriga de La. Depois Gi (f, 34 meses) junta-se, como médica, ao grupo (passa peça de madeira no corpo de La).

\section{Focal de Sílvio}

Continuação da brincadeira que começou no focal do $\mathrm{H}$. La é a paciente, Gi e Hos médicos e $S$ ( $m, 29$ meses) também se junta a eles como médico.

Os excertos evidenciam que uma brincadeira que começou com Laura passando pino de madeira no corpo de uma boneca que estava "morta" propagou-se no grupo e envolveu mais quatro crianças (A, Gi, H e S). O significado das peças de madeira e de plástico como "medicamento" foi compartilhado por estas crianças e persistiu no grupo ao longo de três focais. Gisele e Laura já haviam construído e compartilhado este significado nas duplas.

A comparação dos modos de utilização de objetos e das brincadeiras que surgiram nas sessões de observação semicontrolada (díades e conjuntas) está no Apêndice 19. Os dados que mais chamam a atenção são principalmente aqueles que se repetiram durante mais de uma sessão e que envolveram a imitação do ato de uma criança em relação à outra. Assim, em “tentar abrir os barris girando", Gustavo imita a ação de Sílvio, quando em dupla com ele, e a repete na sessão conjunta 1. Em "jogar a bola para o alto", Gustavo imita a ação de Carlos, durante a sessão conjunta 1 , depois brinca junto com ele e sozinho, repetindo o mesmo ato na mesma sessão e também na sessão conjunta 2. Em "girar a chaminé da casinha”, Carlos imita Heitor, quando em dupla com ele, e repete o ato quando em dupla com Lia e Sílvio (as três duplas ocorreram na $6^{\mathrm{a}}$ fase) e na sessão conjunta 2. Em "virar a garrafinha sobre metade de um barril”, Gisele imita Carlos, quando em dupla com ele, e repete a ação na sessão conjunta 1. Todos estes episódios denotam serem os atos destacados aspectos da microcultura do grupo que "passaram" de uma criança para outra e, assim, persistiram no grupo. 
Quanto aos enredos lúdicos que apareceram em mais de um tipo de sessão (focais, duplas e conjuntas), podem ser apontados os seguintes temas: brincadeira de médico; brincar com arma (atirar, lutar, bater); alimentação (comer, beber); brincar de fazer compras; contar estórias; encaixar e desencaixar peças; brincar de polícia; brincar de mamãe e filhinha(o).

\section{6- Tipos de brincadeiras e efeitos do grau de preferência social e do distanciamento de idades}

O objetivo desta análise foi verificar se o grau de preferência social e a diferença de idade eram variáveis que influenciavam nos tipos de brincadeiras encontradas na última sessão de cada díade $\left(4^{\mathrm{a}}, 5^{\mathrm{a}}\right.$ e $6^{\mathrm{a}}$ fase $)$. As crianças estavam com 16 a 33 meses de idade no período inicial da coleta e 21 a 38 meses de idade no período final. As brincadeiras foram classificadas segundo Morais e Otta (2003), Gosso e Otta (2003) e Parker (1984). Morais e Otta (2003) separam as brincadeiras quanto ao caráter predominante da ação e da forma de interação:

\section{Ação:}

- Brincadeiras de exercício físico - subdividem-se em brincadeiras de contingência física

e exercício sensório-motor. Brincadeiras de contingência física são aquelas em que as crianças percebem a relação entre suas ações no ambiente e as reações delas decorrentes. Através deste tipo de brincadeira, as crianças adquirem noções de relações espaciais, força e funções instrumentais de objetos. Parker (1984) sugere que estas brincadeiras têm valor adaptativo para a prática do uso de ferramentas. Já os exercícios sensório-motores consistem em atividades através das quais as crianças praticam movimentos que lhes trazem sensações cinestésicas e de equilíbrio dinâmico, pelo puro prazer de executá-los (Gosso e Otta, 2003). 
- Brincadeiras de contingência social - são aquelas que envolvem a alternância de papéis entre os participantes e o entendimento de que é possível estabelecer uma relação social com respostas contingentes de ambos os lados. Constituem as primeiras manifestações do esquema de revezamento de papéis, que é característico das conversações posteriores, do faz-de-conta e dos jogos de regras (Parker, 1984).

- Brincadeiras de construção - consistem na combinação de objetos, resultando num produto novo (Morais e Otta, 2003).

- Brincadeiras turbulentas - subdividem-se em (1) agonísticas - envolvem luta, perseguição e fuga. Percebe-se que são brincadeiras, pois são acompanhadas freqüentemente por risos; (2) teste de limites: físico - caracteriza-se pelo exercício físico vigoroso e desafio de limites entre o lícito e o proibido, o seguro e o arriscado; e social - brincadeiras de provocação e zombaria (Morais e Otta, op. cit.)

- Brincadeiras de faz-de-conta/simbólicas/imaginativas - são aquelas em que as crianças atribuem um significado diferente do convencional a objetos, a atividades, a si próprias e aos outros, criando brincadeiras em que representam cenas provenientes de sua imaginação.

- Brincadeiras e jogos com regras - são aqueles em que o enredo da brincadeira gira em torno de regras que estabelecem ações e papéis a serem respeitados. Na brincadeira as sequiências são mais imprevisíveis do que no jogo (talvez por este ter regras mais rígidas). Em geral, os jogos surgem nas crianças por volta dos seis anos de idade, porém crianças menores já apresentam brincadeiras com regras, como siga-o-líder e esconde-esconde, mas que precisam da iniciação ou supervisão de um adulto ou criança mais velha (Parker, 1984).

Segundo Morais e Otta (2003), a maioria das brincadeiras pode ser classificada de acordo com mais de uma dessas categorias; portanto, estabeleceram um critério em que prevalece a categoria que denota maior complexidade de brincadeira: regra $>$ faz-de-conta $>$ construção $>$ turbulenta > contingência social > exercício físico. 


\section{Forma de interação:}

- Brincadeira solitária - quando a criança brinca sozinha e não estabelece nenhuma interação social relacionada ao conteúdo e propósito da brincadeira.

- Brincadeira paralela - quando duas ou mais crianças brincam próximas, de um mesmo tema ou de temas semelhantes, porém sem interagirem quanto à brincadeira.

- Brincadeira associativa - quando duas ou mais crianças se associam para brincar de um mesmo tema, interagindo entre si, mas não cooperam e não dividem tarefas.

- Brincadeira cooperativa - quando há, na brincadeira de duas ou mais crianças sobre um mesmo tema, cooperação ou competição, divisão de tarefas e de papéis.

Além da persistência de significados lúdicos, procurou-se verificar a persistência de relações preferenciais no grupo, construindo-se sociogramas a partir da análise dos focais, das matrizes de proximidade, obtidas dos scans - observações em situação de atividade lúdica livre - e da análise das sessões conjuntas - observações em situação semicontrolada. Os dados provenientes destas duas situações de observação foram comparados entre si, bem como o foram os dados de persistência de significados lúdicos entre as sessões de duplas e as conjuntas.

\section{Resultados}

A Figura 23 mostra as freqüências relativas de cada tipo de brincadeira obtidas para as duplas "preferenciais" e para as "não-preferenciais". A única categoria com diferença significativa quanto ao grau de preferência social foi "contingência social": Teste-T, sig. (2tailled $)=0,039($ pref $>$ n-pref $)$. 


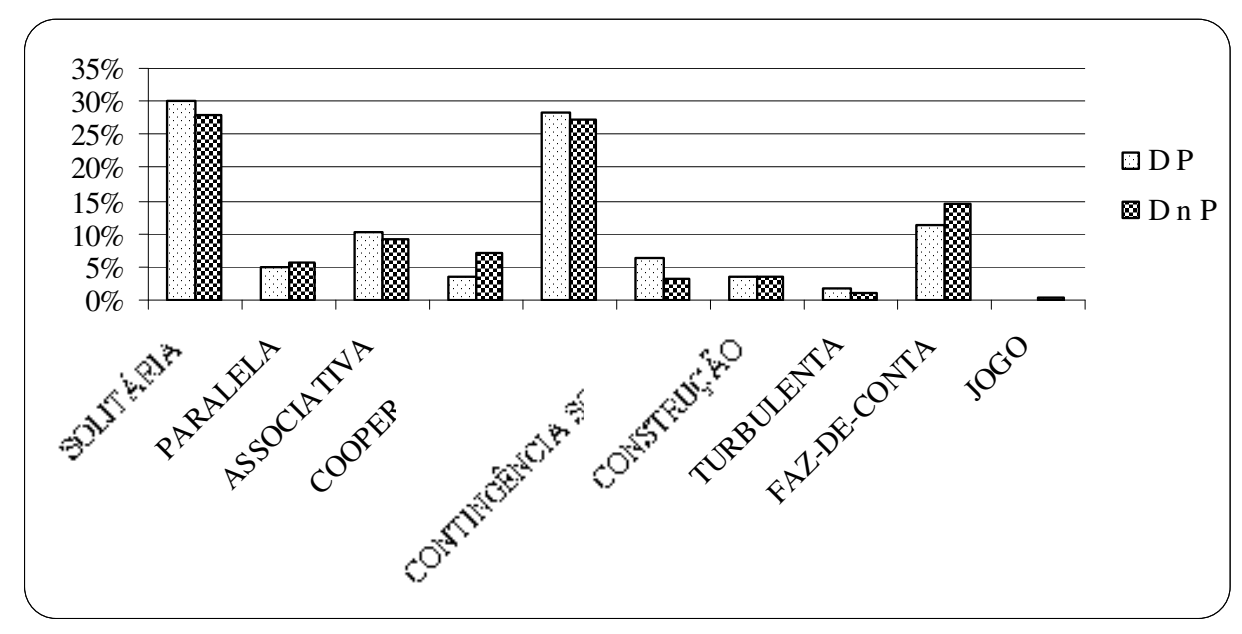

Figura 23 - Freqüência relativa dos tipos de brincadeiras, obtida para díades preferenciais (DP - maior afinidade social) e não-preferenciais (DnP - menor afinidade social) a partir da análise dos 10 minutos iniciais da última sessão de cada dupla de crianças que participaram das sessões de observação em condição semicontrolada (22 sessões ao todo).

Para fins de análise, as díades foram separadas em três grupos quanto à diferença de idade: I- 0 a 5 meses; II- 6 a 11 meses; III- 12 a 17 meses. A Figura 24 mostra as frequiências relativas de cada tipo de brincadeira para os três grupos. Mais uma vez, aplicando-se o Teste$\mathrm{T}$ observou-se diferença significativa somente para a categoria "faz-de-conta" (I e III; $\mathrm{p}=$ 0,023) e uma tendência à significância entre brincadeira: paralela (I e III; p= 0,083); cooperativa (I e III; p= 0,064; II e III; p=0,08) e física (I e II; p=0,072). 


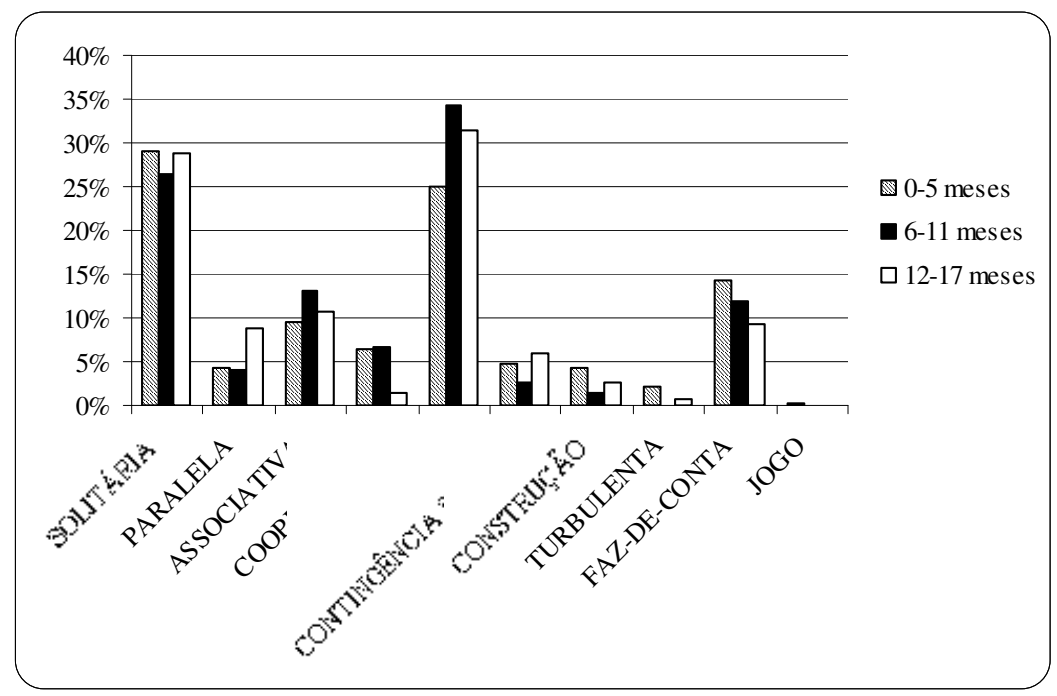

Figura 24 - Freqüência relativa dos tipos de brincadeiras, obtida para cada faixa de diferença de idade existente entre as crianças que fizeram parte da mesma díade, a partir da análise dos 10 minutos iniciais da última sessão de cada dupla que participou das sessões de observação em condição semicontrolada (22 sessões ao todo).

Foram realizadas, adicionalmente, mais duas análises: correlação entre as categorias de brincadeira e Teste-T para a composição de gênero das duplas.

Obteve-se correlação para as brincadeiras:

- De contingência social e associativa: Pearson $=0,530 ;$ sig. $(2$-tailled $)=0,011$;

- De construção e paralela: Pearson $=0,459$; sig. $(2$-tailled $)=0,032$;

- $\quad$ Turbulenta e cooperativa: Pearson $=0,588 ;$ sig. $(2$-tailled $)=0,004$;

- $\quad$ Física e paralela: Pearson =0,495; sig. $(2$-tailled $)=0,019$;

- Física e solitária: Pearson =0,642; sig. $(2$-tailled $)=0,001$;

- Turbulenta e construção: Pearson $=0,475$; sig. $(2$-tailled $)=0,025$.

Quanto ao efeito de gênero das duplas e os tipos de brincadeiras, as duplas mistas (formadas por menino e menina) apresentaram significativamente mais brincadeiras do tipo física do que as duplas formadas apenas por meninas $(\mathrm{p}=0,053)$ e significativamente mais 
brincadeiras de faz-de-conta do que as duplas formadas apenas por meninos $(p=0,028)$. Além disso, nas duplas formadas somente por meninas, apareceram significativamente mais brincadeiras de faz-de-conta do que nas duplas formadas somente por meninos $(p=0,050)$; por outro lado, nestas duplas houve significativamente mais brincadeiras do tipo paralela do que nas duplas constituídas somente por meninas $(\mathrm{p}=0,034)$.

A hipótese inicial era de que as duplas com maior afinidade social brincassem mais juntas, o que poderia ser explicitado pela freqüência de brincadeiras associativas e de cooperativas. No entanto, não houve diferença significativa entre estas categorias para as duplas com maior ou menor preferência social. Algumas explicações podem ser propostas para compreender este resultado:

1) Como o acesso ao nível de preferência social foi feito indiretamente, a partir da proximidade física das crianças nos scans, pode ser que este método não tenha garantido uma medida real da preferência social entre as crianças. Porém, Carvalho \& Rubiano (2004) relatam que a observação de dois grupos de creches diferentes gerou redes de relações semelhantes através de critérios distintos: compartilhamento de atividades; busca de contato social ou abordagem do parceiro; proximidade física e relato das educadoras. Além disso, foram analisados 62 scans e considerado o julgamento das educadoras;

2) A situação experimental (semicontrolada) promove uma condição diversa em relação àquela da observação em momentos de atividade lúdica livre, no qual as crianças podiam escolher os seus parceiros e a diversidade de objetos era maior. Ali, havia apenas um parceiro e dez pares de objetos para brincar; 
3) Pode ser que a ausência das educadoras na situação experimental tenha levado a uma maior união mesmo entre parceiros não-preferenciais, por não haver a presença protetora, mediadora de conflitos e doadora de atenção das educadoras.

Já a maior freqüência de brincadeiras de contingência social nas duplas preferenciais do que nas não-preferenciais corrobora com a hipótese de que, nas primeiras, as crianças brincariam mais juntas do que nas segundas, pois, apesar de contingência social ser uma categoria de ação, ela é uma das únicas necessariamente sociais.

Quanto às categorias de diferença de idade, os resultados mostram que há mais faz-deconta nas duplas em que a diferença de idade é de até 5 meses, do que naquelas em que a diferença é maior do que 1 ano. Outro fator que influencia neste resultado é que as crianças do primeiro grupo tinham idade média de 3 anos (33 a 38 meses) e, por serem mais velhas, era esperado que apresentassem mais episódios de faz-de-conta do que as duplas em que uma das crianças tinha cerca de 2 anos de idade. Um dado qualitativo é que as brincadeiras de faz-deconta observadas foram tornando-se cada vez mais complexas com o tempo, como: brincar de médico, de mãe e pai, de mamãe e filhinho. Este resultado corrobora a afirmação de Morais (2004), de que, à medida em que as crianças se desenvolvem e se tornam mais competentes do ponto de vista lingüístico, elas representam cenas ainda mais longas e elaboradas da vida cotidiana.

Finalmente, os resultados das diferenças de gênero estão de acordo com a literatura consultada (Morais e Otta, 2003): meninos engajam-se mais em brincadeiras de exercício físico do que meninas e, no entanto, elas apresentam mais faz-de-conta do que eles (já por volta dos 3 anos de idade!). 


\section{7- Análise do brincar, das parcerias preferenciais e da forma de comunicação (verbal ou ausência de verbal)}

Os quatro primeiros focais, os quatro intermediários e os quatro últimos focais de cada criança que permaneceu no grupo do início ao fim da pesquisa foram analisados e comparados quanto às formas e os tipos de brincadeiras, as parcerias preferenciais e as freqüências de verbalizações e de ausência de verbalizações em diferentes situações. O intuito desta análise foi o de identificar diferenças nos modos de brincar, interagir e se comunicar das crianças ao longo dos 17 meses de coleta de dados.

Os diversos tipos de brincadeiras dos sujeitos-focais foram classificados em três categorias: I) Brincadeira solitária - a criança brinca sozinha; II) Brincadeira acompanhada a criança brinca com uma ou mais crianças; III) Brincadeira solitária com interação - a criança brinca sozinha, mas às vezes interage com outra criança (esta interação pode ser agonística ou não).

\section{Resultados}

Pode-se observar (Figura 25) que, embora as crianças se diferenciem bastante quanto às formas de brincadeira, no primeiro período $(\mathrm{P})$ houve uma tendência das meninas apresentarem menos brincadeiras solitárias (com exceção de A) e delas brincarem acima da média $(16,7 \%)$ com outras crianças. Já os meninos têm uma distribuição mais semelhante entre as três categorias de brincadeiras, porém $\mathrm{S}$ brincou bastante sozinho. No período intermediário (M), Gi e La destacam-se na brincadeira acompanhada (frequiências de 38,1\% e $33,3 \%$, respectivamente). Os meninos, por outro lado, são os que menos brincaram com outras crianças. Finalmente, no último período (U), A, C e $\mathrm{H}$ apresentam uma freqüência 
igual e acima da média $(23,3 \%)$ para brincadeira solitária, e o mesmo acontece para La, C e S para brincadeira acompanhada (25,0\%). A é a única criança que não brincou com outra neste período. Além disso, La mostra uma freqüência elevada de brincadeira solitária com interação $(40,0 \%)$

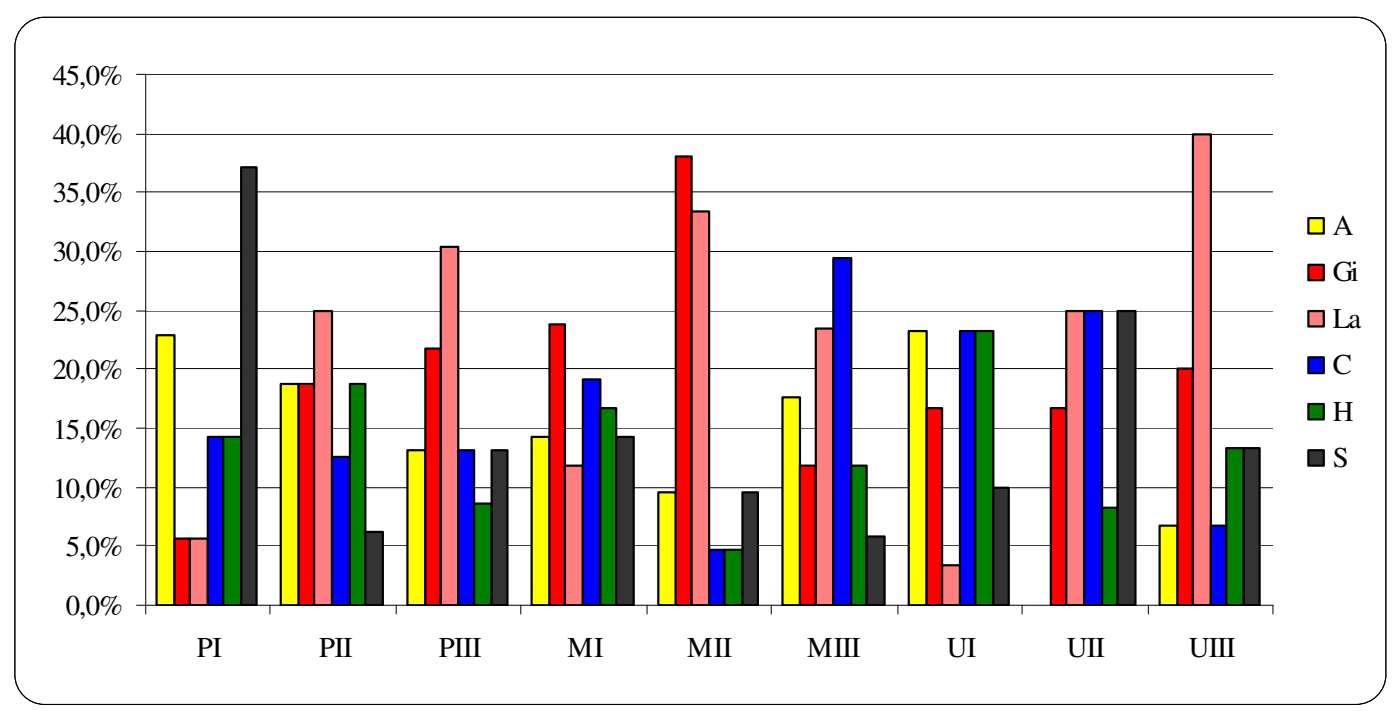

Figura 25 - Freqüência relativa (porcentagem) das formas de brincadeiras - solitária (I), acompanhada (II) e solitária com interação (III) - nos quatro primeiros (P) focais $(21 / 8 / 03$ a 22/9/03), quatro focais intermediários $(\mathrm{M} ; 25 / 3 / 04$ a 28/4/04) e quatro últimos (U) focais (13/10/04 a 16/11/04) para cada criança (meninas: A, Gi, La; meninos: C, H e S).

Aplicando-se o Teste $\mathrm{T}$ para amostras pareadas a fim de comparar as médias das categorias de brincadeira nos três períodos investigados, verificou-se uma diminuição significativa da média de brincadeira solitária com interação (III) do primeiro período em relação ao último período $(\mathrm{T}=4,00 ; \mathrm{p}=0,01)$ e uma tendência a uma menor freqüência de brincadeira solitária nos últimos focais do que nos intermediários $(T=2,07 ; p=0,09)$. Quanto à brincadeira acompanhada, embora as médias aumentem de um período para o seguinte, a diferença entre elas não chega a ser significativa - talvez pelo número reduzido da amostra.

Também foi aplicado o teste de correlação de Pearson entre as categorias de brincadeira para cada período. Obteve-se uma correlação significativa apenas entre o brincar 
solitário (I) e o brincar solitário com interação (III) no último período - Pearson= - 0,845; sig. (2-tailed) $=0,034-$ e entre brincadeira acompanhada (II) e brincadeira solitária (I) no período intermediário - Pearson $=-0,805 ;$ sig. $(2$-tailed $)=0,053$. Ou seja, parece que, no último período, as crianças que brincaram mais sozinhas apresentaram menos brincadeira solitária com interação e vice-versa; enquanto houve uma tendência, no período intermediário, às crianças que brincaram mais sozinhas terem brincado menos acompanhadas (e vice-versa).

A análise das parcerias preferenciais entre as crianças em cada período foi feita construindo-se matrizes de dupla entrada para as "brincadeiras acompanhadas" do sujeitofocal. Neste caso, foram consideradas também as crianças que não fizeram parte do grupo do início ao fim da pesquisa e com quem o sujeito-focal brincou (Tabela 19).

Tabela 19 - Número de vezes que o sujeito-focal (a primeira sigla a aparecer em cada par na tabela) foi visto brincando com outra criança nos quatro primeiros focais (21/8/03 a 22/9/03), quatro focais intermediários (25/3/04 a 28/4/04) e quatro últimos focais (13/10/04 a 16/11/04). O sujeito-focal é representado pela primeira sigla a aparecer em cada par na tabela.

\begin{tabular}{|c|c|c|c|}
\hline Pares / Focais & Primeiros & Intermediários & Últimos \\
\hline A-B & $*$ & $*$ & 0 \\
\hline A-C & 2 & 0 & 1 \\
\hline A-Gi & 1 & 0 & 0 \\
\hline A-Gu & $*$ & 1 & 0 \\
\hline A-H & 0 & 1 & 0 \\
\hline A-La & 0 & 0 & 0 \\
\hline A-Li & $*$ & $*$ & 0 \\
\hline A-M & $*$ & 0 & $*$ \\
\hline A-S & 3 & 2 & 0 \\
\hline C-B & $*$ & $*$ & 0 \\
\hline C-Gi & 3 & 5 & 2 \\
\hline C-Gu & $*$ & 0 & 0 \\
\hline $\mathrm{C}-\mathrm{H}$ & 1 & 0 & 2 \\
\hline C-La & 2 & 6 & 1 \\
\hline C-Li & $*$ & $*$ & 0 \\
\hline C-M & $*$ & 0 & $*$ \\
\hline C-S & 3 & 0 & 4 \\
\hline Gi-B & $*$ & $*$ & 2 \\
\hline Gi-Gu & $*$ & 0 & 1 \\
\hline Gi-H & 1 & 2 & 2 \\
\hline
\end{tabular}




\begin{tabular}{l|c|c|c}
\hline Pares / Focais & Primeiros & Intermediários & Últimos \\
\hline Gi-La & 2 & 3 & 1 \\
\hline Gi-Li & $*$ & $*$ & 0 \\
\hline Gi-M & $*$ & 1 & 5 \\
\hline Gi-S & 1 & 2 & 0 \\
\hline H-B & $*$ & $*$ & 0 \\
\hline H-Gu & $*$ & 0 & 0 \\
\hline H-La & 4 & 1 & 0 \\
\hline H-M & $*$ & $*$ & $*$ \\
\hline H-S & $*$ & 1 & 4 \\
\hline La-B & $*$ & $*$ & 0 \\
\hline La-Gu & $*$ & 1 & 0 \\
\hline La-Li & $*$ & $*$ & $*$ \\
\hline La-M & $*$ & 0 & 5 \\
\hline La-S & 1 & 0 & 0 \\
\hline S-B & $*$ & $*$ & 0 \\
\hline S-Li & $*$ & 0 & $*$ \\
\hline S-M & $*$ & $*$ & 0 \\
\hline
\end{tabular}

* A criança não fazia parte do grupo no período $(\mathrm{B}, \mathrm{Gu}, \mathrm{Li}$ e M).

A Tabela 19 mostra que algumas crianças brincaram repetidas vezes com outra no mesmo período ou mesmo em períodos diferentes e que outras crianças não foram vistas brincando com outra em nenhum período (por exemplo, A-La, C-Gu, H-Gu e S-Gu). A Tabela 20 apresenta estes resultados de modo mais claro.

Tabela 20 - Número de vezes que cada par de crianças brincou junto durante os primeiros focais, intermediários e últimos focais. As duplas marcadas com cor correspondem àquelas que foram vistas brincando juntas nos três períodos.

\begin{tabular}{|c|c|c|c|}
\hline $\begin{array}{l}\text { Brincar com mesma } \\
\text { criança }\end{array}$ & Primeiros & Intermediários & Últimos \\
\hline Seis vezes & -- & C-La & -- \\
\hline Cinco vezes & -- & C-Gi & Gi-S; La-S \\
\hline Quatro vezes & $\mathrm{H}-\mathrm{La}$ & -- & $\mathrm{C}-\mathrm{S} ; \mathrm{H}-\mathrm{S}$ \\
\hline Três vezes & A-S; C-Gi; C-S & Gi-La & -- \\
\hline Duas vezes & A-C; C-La; Gi-La & A-S; Gi-H; Gi-S & $\begin{array}{l}\text { C-Gi; C-H; Gi-B; } \\
\text { Gi-H }\end{array}$ \\
\hline Uma vez & $\begin{array}{l}\text { A-Gi; C-H; Gi-H; } \\
\text { Gi-S; H-S; La-S }\end{array}$ & $\begin{array}{c}\text { A-Gu; A-H; Gi-M; } \\
\text { H-M; H-La; H-S; } \\
\text { La-Gu }\end{array}$ & $\begin{array}{l}\text { A-C; C-La; Gi-Gu; } \\
\text { Gi-La; La-Li }\end{array}$ \\
\hline
\end{tabular}


Pode-se observar (Tabela 20) que as duplas C-Gi, C-La, Gi-La, Gi-H, Gi-S e H-S brincaram junto em todos os períodos medidos, o que pode ser caracterizado como persistência em termos de relações preferenciais. A dupla C-La foi a que brincou mais vezes junto (seis, nos focais intermediários), seguida de C-Gi, Gi-S e La-S (cinco vezes) e H-La, C$\mathrm{S}$ e H-S (quatro vezes). Estes resultados podem ser comparados com aqueles do item 5.5, confirmando-se a persistência das díades C-La e Gi-H. Além disso, a Tabela 21 mostra que algumas crianças tiveram vários parceiros de brincadeira, enquanto outras tiveram apenas alguns. Nos primeiros focais, A foi a que teve menor número de parceiros (três), e C, Gi e S o maior número (cinco), ou seja, eles brincaram ao menos uma vez com todas as outras crianças do grupo. Nos focais intermediários, $\mathrm{C}$ brincou apenas com duas crianças (Gi e La), enquanto Gi e H brincaram com cinco das sete presentes no período. Neste período, Gu e M, que não foram considerados como sujeitos-focais na análise por não terem feito parte do grupo do início ao fim do período de coleta de dados, brincaram, cada um, com duas crianças diferentes (Gu com A e La; M com Gi e H), uma única vez. Nos últimos focais, A brincou apenas com uma criança (C), Gi brincou com seis das oito crianças presentes no período e $\mathrm{C}$ com cinco crianças. B, Gu e Li, crianças não consideradas como sujeito-focal, brincaram, cada um, com uma única criança (B duas vezes com Gi; Gu uma vez com Gi; e Li uma vez com La). 
Tabela 21 - Número de parceiros diferentes de brincadeira que cada criança teve nos três períodos analisados (primeiros focais, intermediários e últimos focais). As letras que aparecem entre parênteses correspondem às crianças que não foram consideradas como sujeitos-focais por não terem permanecido no grupo do início ao fim do período de coleta de dados.

\begin{tabular}{l|c|c|c}
\hline \multirow{2}{*}{ Criança } & \multicolumn{3}{|c}{ Número de parceiros diferentes de brincadeira } \\
\cline { 2 - 4 } & Primeiros & Intermediários & Últimos \\
\hline $\mathrm{A}$ & 3 & 3 & 1 \\
\hline $\mathrm{C}$ & 5 & 2 & 5 \\
\hline $\mathrm{Gi}$ & 5 & 5 & 6 \\
\hline $\mathrm{H}$ & 4 & 5 & 3 \\
\hline $\mathrm{La}$ & 4 & 4 & 4 \\
\hline $\mathrm{S}$ & 5 & 3 & 4 \\
\hline$(\mathrm{B})$ & $*$ & $*$ & 1 \\
\hline$(\mathrm{Gu})$ & $*$ & 2 & 1 \\
\hline$(\mathrm{Li})$ & $*$ & $*$ & 1 \\
\hline$(\mathrm{M})$ & $*$ & 2 & $*$ \\
\hline
\end{tabular}

* Criança não fazia parte do grupo no período.

Os resultados das Tabelas 20 e 21, em conjunto, indicam que algumas crianças, como Gi e La, brincaram com muitos parceiros tanto quanto com um mesmo parceiro (parcerias preferenciais); já A, foi uma das crianças que brincou com um menor número de parceiros diferentes e a única das seis que não apresentou persistência de relações preferenciais para os períodos medidos. Isto demonstra estilos diferentes das crianças brincarem e interagirem entre si: algumas se caracterizam por um brincar mais solitário, outras por um brincar com um ou mais parceiros específicos e, outras, ainda, por um brincar com diversas crianças. Outra observação que pode ser feita é quanto às crianças que não fizeram parte do grupo durante todo o período de coleta de dados. Aparentemente, elas não tiveram tempo de estabelecer relações sociais tão próximas com os outros integrantes do grupo quanto às crianças que estavam juntas desde a mais tenra idade (desde os quatro meses, aproximadamente).

Quanto à análise das verbalizações das crianças, ela foi feita para as três formas de brincadeiras descritas anteriormente: solitária - I; acompanhada - II; e solitária com interação III (Figuras 26 e 27). É importante esclarecer que cada verbalização poderia corresponder a 
diversas palavras, tendo sido considerada a presença ou não de verbalizações durante a brincadeira em que cada sujeito-focal estava envolvido.

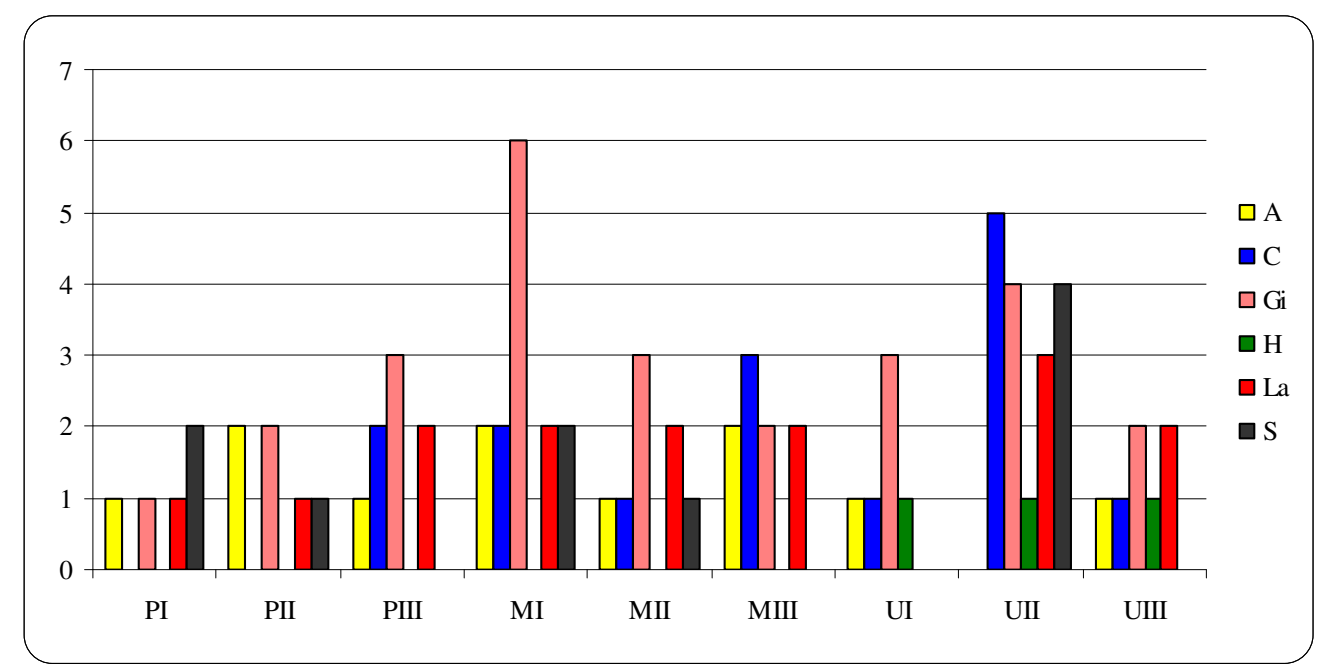

Figura 26 - Número de verbalizações detectadas nos quatro primeiros (P) focais $(21 / 8 / 03$ a 22/9/03), quatro focais intermediários (M, 25/3/04 a 28/4/04) e quatro últimos (U) focais (13/10/04 a 16/11/04) de cada criança (A, C, Gi, H, La e S), durante brincadeira solitária (I), acompanhada (II) e solitária com interação (III). Não foram consideradas as verbalizações dirigidas a adultos (educadoras, funcionários, pesquisadora).

A Figura 26 mostra que no primeiro período $(\mathrm{P})$ não foram detectadas verbalizações durante a brincadeira solitária e a acompanhada para $\mathrm{C}$ e $\mathrm{H}$, e, durante a brincadeira solitária com interação, para H e S. Tais resultados podem ser explicados por C e S serem as crianças mais novas e $\mathrm{H}$ ter apresentado um atraso no desenvolvimento da fala - de fato, foram detectadas verbalizações de $\mathrm{H}$ durante a brincadeira somente no último período (U). As verbalizações das crianças, em geral, tiveram uma freqüência baixa - máximo de três verbalizações para Gi em brincadeira solitária com interação. Gi também foi a criança que apresentou maior frequiência de verbalizações no segundo período (M), mas quando em brincadeira solitária (seis vezes). Para as outras crianças, com exceção de $\mathrm{H}$, foi detectado um mesmo número de verbalizações (duas) durante esta forma de brincar. Em brincadeira acompanhada, Gi e La apresentaram mais verbalizações (três e duas, respectivamente), e em 
brincadeira solitária com interação, $\mathrm{C}$ apresentou um maior número de verbalizações (três), enquanto as outras crianças (menos $\mathrm{H}$ ), verbalizaram duas vezes. No último período, pode-se notar uma "concentração" das verbalizações durante a brincadeira acompanhada, com exceção de A, que não verbalizou nenhuma vez.

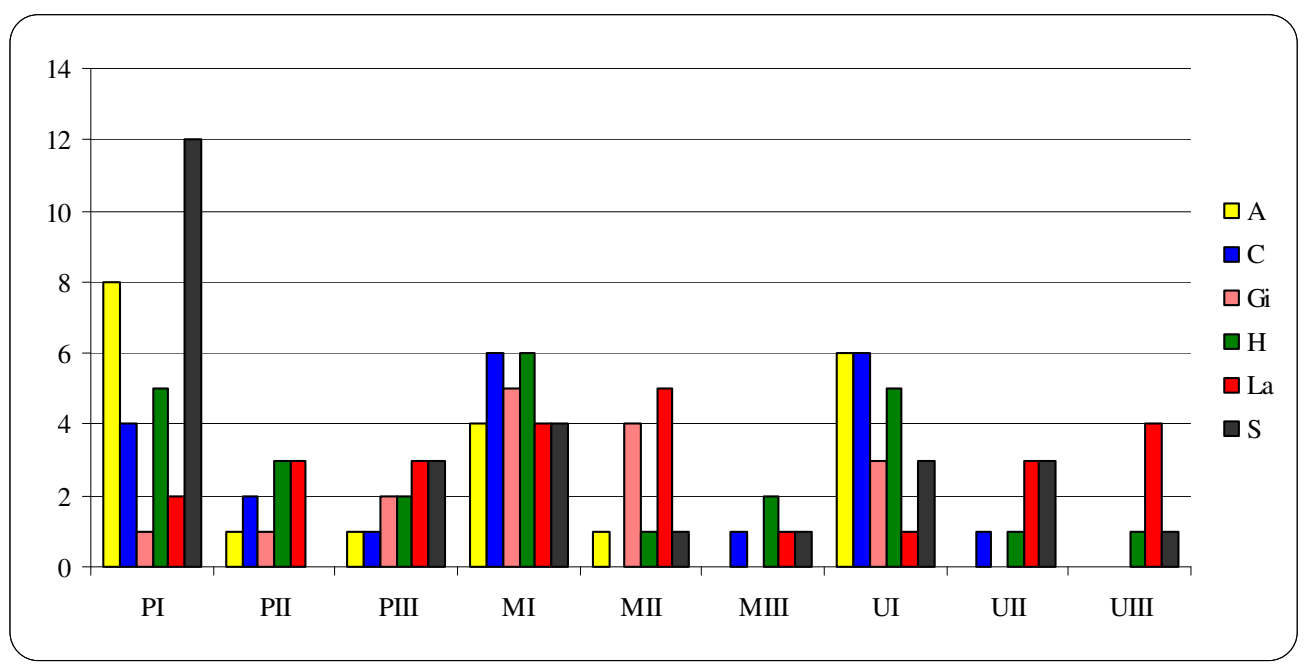

Figura 27 -Número de ausência de verbalizações detectadas nos quatro primeiros (P) focais (21/8/03 a 22/9/03), quatro focais intermediários (M, 25/3/04 a 28/4/04) e quatro últimos (U) focais (13/10/04 a 16/11/04) de cada criança (A, C, Gi, H, La e S), durante brincadeira solitária (I), acompanhada (II) e solitária com interação (III). Não foram consideradas as verbalizações dirigidas a adultos (educadoras, funcionários, pesquisadora).

Quanto à ausência de verbalizações, as maiores frequiências foram encontradas nas brincadeiras solitárias de todos os períodos, destacando-se S (12 vezes) e A (oito vezes) no primeiro período $(\mathrm{P})$. No último período $(\mathrm{U})$, parece ter havido uma menor freqüência de ausência de verbalizações durante as brincadeiras acompanhadas e brincadeiras solitárias com interação, do que nos dois períodos anteriores.

Analisando-se os dados de verbalização e ausência de verbalização estatisticamente, obteve-se que o número de ausência de verbalizações em brincadeiras com interação no período intermediário é significativamente menor do que no primeiro período $(T=2,91 ; p=$ 0,03). Também houve uma tendência à significância: do número de ausência de verbalizações 
em brincadeiras com interação no último período ser menor do que no primeiro $(\mathrm{T}=2,24 ; \mathrm{p}=$ 0,08); do número de verbalizações em brincadeiras solitárias ser maior no período intermediário do que no primeiro período $(\mathrm{T}=1,96 ; \mathrm{p}=0,11)$ e do que no último período $(\mathrm{T}=$ 2,4; $\mathrm{p}=0,06)$; e, finalmente, do número de verbalizações em brincadeiras acompanhadas no último período ser maior do que no período intermediário $(\mathrm{T}=2,09 ; \mathrm{p}=0,09)$ e do que no primeiro período $(\mathrm{T}=1,9 ; \mathrm{p}=0,11)$. As outras diferenças das verbalizações e ausência de verbalizações entre as formas de brincar nos três períodos não foram significativas. Estes resultados permitem concluir que as crianças, ao brincarem sozinhas mas interagirem com outras tenderam a diminuir a frequiência de ausência de verbalizações com o tempo e, ainda, que ao brincarem acompanhadas, as crianças tenderam a verbalizar mais com o aumento da idade.

Também foi verificado se existia correlação entre verbalização, ausência de verbalização e formas de brincadeiras nos três períodos. Obteve-se correlação significativa para:

VPI e NVMI: Pearson = -0,856; sig. (2-tailled $)=0,030 \rightarrow$ as crianças que verbalizaram mais quando brincando sozinhas no primeiro período, apresentaram menor freqüência de ausência de verbalização quando brincando sozinhas no segundo período (e vice-versa);

VMI e VMII: Pearson = 0,919; sig. (2-tailled) $=0,010 \rightarrow$ as crianças que verbalizaram mais quando brincando sozinhas no período intermediário, também verbalizaram mais quando brincando com outras crianças no mesmo período (e vice-versa);

NVPI e VUIII: Pearson $=-0,933$; sig. $(2$-tailled) $=0,007 \rightarrow$ as crianças que apresentaram maiores frequiências de ausência de verbalização em brincadeira solitária no primeiro período, verbalizaram menos em brincadeira solitária com interação no último período (e vice-versa); 
VPIII e VMII: Pearson = 0,853; sig. (2-tailled) $=0,031 \rightarrow$ as crianças que verbalizaram mais quando em brincadeira solitária com interação no primeiro período, também verbalizaram mais quando brincando com outras crianças no período intermediário (e vice-versa);

NVPIII e NVUI: Pearson $=-0,894$; sig. $(2$-tailled $)=0,016 \rightarrow$ as crianças que apresentaram maior frequiência de ausência de verbalização em brincadeira solitária com interação no primeiro período, tiveram menor freqüência de ausência de verbalização quando brincando sozinhas no último período (e vice-versa);

NVPIII e NVUII: Pearson $=0,818$; sig. $(2$-tailled $)=0,047 \rightarrow$ as crianças que apresentaram maior frequiência de ausência de verbalização em brincadeira solitária com interação no primeiro período, tiveram maior freqüência de ausência de verbalização quando brincando com outras crianças no último período (e vice-versa);

VPII e NVMIII: Pearson $=-0,891$; sig. $(2$-tailled $)=0,017 \rightarrow$ as crianças que verbalizaram mais quando brincando com outras no primeiro período, tiveram menor freqüência de ausência de verbalização em brincadeira solitária com interação no período intermediário;

NVMII e NVUI: Pearson = -0,850; sig. (2-tailled) $=0,032 \rightarrow$ as crianças que apresentaram maior freqüência de ausência de verbalização quando brincando com outras no período intermediário, tiveram menor freqüência de ausência de verbalização quando brincando sozinhas no último período (e vice-versa);

O que parece importante concluir destes dados é que, no período intermediário, as crianças que verbalizavam mais sozinhas também verbalizavam mais quando brincando com um parceiro ou uma parceira, e, ainda, que parece ter havido uma tendência às crianças falarem mais sozinhas, inicialmente, depois com outras crianças quando interagiam com elas em brincadeira solitária e, enfim, a falar mais quando brincavam com um colega. Pode-se afirmar que a "explosão" no desenvolvimento da fala, para o grupo analisado, esteve no 
período intermediário, quando suas idades estavam compreendidas entre 1 ano e 10 meses (Carlos) e 2 anos e 6 meses (Gisele).

\section{8.- Brincadeiras usuais ou não-usuais com objeto e brincadeiras sem objeto}

A fim de explorar mais os dados sobre brincadeira registrados durante os focais do último semestre de observação em situação de atividade lúdica livre (item 5.5 e Apêndice 14), as brincadeiras foram reclassificadas em termos do tipo de ação realizada pela criança em: "ação ${ }^{13}$ usual com objeto", "ação não-usual com objeto" e "ação sem objeto". As brincadeiras foram consideradas usuais, ou seja, comuns, ou não, partindo-se do pressuposto de que os objetos possuem funções culturalmente construídas e, assim, ações esperadas sobre eles. Foi registrado, também, o sexo das crianças em cada brincadeira, para saber se havia diferença entre meninos e meninas.

A idéia de classificar as brincadeiras dessa forma surgiu a partir do conhecimento que a pesquisadora teve sobre a A Teoria da Ação Simbólica, que se apóia nos conceitos de cultura, ação e objeto, e foi desenvolvida por um psicólogo suíço chamado Ernst Boesch. Segundo esta concepção, a cultura é o campo de ação do indivíduo; ao atuar, ele dá significado ao objeto e a si mesmo. Ou, nas palavras de Boesch (2001), “cultura é um sistema de referência, significando que, cada item ou evento num campo cultural relaciona-se com outros itens ou eventos" (pp. 479). Ao mesmo tempo em que a cultura possibilita a ação, ela também a limita. A ação visa a estados futuros do indivíduo. A meta de uma ação é determinada tanto por fatores internos ao sujeito quanto externos, tanto subjetivos quanto objetivos, tanto passados, quanto presentes. Mais exatamente, a meta é sobre-determinada, originando-se de diferentes motivações, bem como polivalente, pois promete satisfazer

\footnotetext{
13 “Ação”e "função", usual ou não, em relação ao objeto estão sendo usadas como sinônimos, neste trabalho.
} 
expectativas diversas (Boesch, 2001). Na teoria boeschiana, "ação e objeto são praticamente indissociáveis: toda ação se dirige para um objeto e todo objeto ganha significado pela ação dirigida a ele" (Simão, 2002a). Além do significado (pessoal) que o sujeito concede ao objeto ao agir sobre ele, há um outro significado simbólico, que é dado pela cultura e, portanto, compartilhado (pelo menos pelos membros de determinada cultura), e outros significados que são provenientes de suas características físicas, como material, forma, volume, cor e pêso. Tais características também influenciam a ação do sujeito sobre o objeto. Como ação e objeto são inseparáveis e toda ação é feita por um sujeito, pode-se afirmar que objeto e sujeito “compõem uma díade em que cada um define o outro, sem entretanto haver uma fusão que os descaracterize enquanto instâncias particulares" (Simão, 2002a, pp. 89-90; itálico da autora). A ação simbólica tem um caráter duplo: cognitivo-racional e afetivo-emocional. Simão (2001) propõe considerar o outro (no sentido de parceiro social, outrem, alteridade) como um objeto de Boesch. Assim, uma vez que a constituição subjetiva se dá na ação do sujeito sobre um objeto, o outro contribuirá para o estabelecimento da identidade do sujeito (e este para a do outro). Além disso, o outro, também capaz de simbolizar, é uma fonte perene de ambigüidade para o sujeito, pois este não pode prever as ações do outro com exatidão.

\section{Resultados}

Comparando-se os modos de utilização dos objetos (Tabela 22), aqueles que suscitaram mais ações usuais das crianças (do que não-usuais) foram (diferença $\geq$ quatro eventos): acessórios; bonecas; um brinquedo chamado "pipoquinha"; outro que imitava uma cesta de frutas; cadernos; carrinho de madeira com pinos de encaixar; cestas de plástico; ferro de passar roupas; revistas, livros e folhetos de supermercado; e utensílios de cozinha. Já os objetos que as crianças utilizaram de forma mais não-usual do que usual foram: caixa de 
videocassete; capacete de plástico; embalagens de cosméticos; mesas e cadeiras; secadores de cabelo e tampas de embalagens.

Tabela 22 - Categorias de objetos com os quais se observou as crianças brincando nas sessões de observação de atividade lúdica livre (focais do último semestre), número de ações usuais (comuns) ou não efetuadas sobre os objetos de acordo com o sexo das crianças $\left(\mathrm{S}_{\mathrm{f}}=\right.$ feminino; $S_{m}=$ masculino) e total de cada tipo de uso, dos sujeitos-focais que foram observados brincando com os objetos. OBS.: Tabela construída a partir dos dados contidos no Apêndice 14.

\begin{tabular}{|c|c|c|c|c|c|c|}
\hline \multirow{2}{*}{ Categoria de objetos } & \multicolumn{3}{|c|}{ Ação usual com objeto } & \multicolumn{3}{|c|}{ Ação não-usual com objeto } \\
\hline & $\mathrm{Sf}$ & $\mathrm{Sm}$ & Total & $\mathrm{Sf}$ & $\mathrm{Sm}$ & Total \\
\hline $\begin{array}{l}\text { Acessórios (bolsas, mochilas, sacolas, } \\
\text { sapatos, chapéus) }\end{array}$ & 7 & 5 & 12 & 3 & 2 & 5 \\
\hline Alimentos (fatias de pizza de plástico) & 4 & 1 & 5 & 1 & 2 & 3 \\
\hline Almofada & 0 & 0 & 0 & 1 & 0 & 1 \\
\hline Animais de plástico & 0 & 0 & 0 & 1 & 2 & 3 \\
\hline Bichos de pelúcia & 0 & 0 & 0 & 1 & 0 & 1 \\
\hline Bolas & 1 & 0 & 1 & 0 & 0 & 0 \\
\hline Bonecas & 16 & 5 & 21 & 1 & 1 & 2 \\
\hline Bonequinhos de plástico ("super-heróis") & 0 & 2 & 2 & 1 & 1 & 2 \\
\hline $\begin{array}{l}\text { Brinquedo com alavancas para atirar } \\
\text { bolinhas que ficam dentro de uma cúpula } \\
\text { ("pipoquinha") }\end{array}$ & 0 & 5 & 5 & 0 & 0 & 0 \\
\hline $\begin{array}{l}\text { Brinquedos com orifícios e peças para } \\
\text { encaixar }\end{array}$ & 1 & 1 & 2 & 0 & 0 & 0 \\
\hline $\begin{array}{l}\text { Brinquedo que é uma cesta de frutas (coloca- } \\
\text { se a colher dentro e "sai" uma fruta - } \\
\text { grudada na colher) }\end{array}$ & 2 & 4 & 6 & 0 & 0 & 0 \\
\hline Cadeirinha de plástico para boneca & 0 & 0 & 0 & 0 & 1 & 1 \\
\hline Cadernos & 3 & 4 & 7 & 1 & 0 & 1 \\
\hline Caixa para guardar óculos & 1 & 0 & 1 & 0 & 0 & 0 \\
\hline Caixa de fita de videocassete & 0 & 0 & 0 & 3 & 3 & 6 \\
\hline Capacete (de plástico) & 0 & 0 & 0 & 1 & 3 & 4 \\
\hline Carrinho de madeira com pinos de encaixar & 2 & 4 & 6 & 1 & 1 & 2 \\
\hline $\begin{array}{l}\text { Carrinhos (de bombeiro, de metal, de } \\
\text { madeira, de plástico, caminhão) }\end{array}$ & 7 & 12 & 19 & 7 & 9 & 16 \\
\hline Carrinhos de bebê para bonecas & 2 & 2 & 4 & 2 & 1 & 3 \\
\hline Casinha da brinquedoteca & 1 & 1 & 2 & 1 & 1 & 2 \\
\hline Cestas de plástico & 4 & 1 & 5 & 0 & 0 & 0 \\
\hline Colchão & 0 & 0 & 0 & 0 & 1 & 1 \\
\hline $\begin{array}{l}\text { Coração de pelúcia com fio e ventosa na } \\
\text { ponta (para ser pendurado) }\end{array}$ & 0 & 1 & 1 & 0 & 0 & 0 \\
\hline Embalagem de termômetro & 1 & 0 & 1 & 0 & 0 & 0 \\
\hline $\begin{array}{l}\text { Embalagens de alimentos (catchup, } \\
\text { mostarda, sorvete, margarina etc) }\end{array}$ & 3 & 2 & 5 & 1 & 2 & 3 \\
\hline $\begin{array}{l}\text { Embalagens de cosméticos (xampu, creme, } \\
\text { desodorante) }\end{array}$ & 3 & 2 & 5 & 7 & 5 & 12 \\
\hline Estante de madeira & 0 & 0 & 0 & 2 & 0 & 2 \\
\hline Ferro de passar roupas & 6 & 0 & 6 & 0 & 0 & 0 \\
\hline Fronha & 0 & 0 & 0 & 0 & 1 & 1 \\
\hline
\end{tabular}




\begin{tabular}{|c|c|c|c|c|c|c|}
\hline \multirow{2}{*}{ Categoria de objetos } & \multicolumn{3}{|c|}{ Ação usual com objeto } & \multicolumn{3}{|c|}{ Ação não-usual com objeto } \\
\hline & Sf & $\mathrm{Sm}$ & Total & $\mathrm{Sf}$ & $\mathrm{Sm}$ & Total \\
\hline Geladeira, fogão, máquina de lavar roupas & 2 & 2 & 4 & 1 & 0 & 1 \\
\hline Lápis de cor, giz de cera & 0 & 0 & 0 & 1 & 0 & 1 \\
\hline Livro de estórias inflado & 0 & 0 & 0 & 1 & 1 & 2 \\
\hline Mesas, cadeiras & 1 & 0 & 1 & 4 & 4 & 8 \\
\hline Objetos não identificados (pequenos) & 0 & 1 & 1 & 0 & 0 & 0 \\
\hline Panos, lenços, tecidos & 4 & 2 & 6 & 2 & 1 & 3 \\
\hline Peças de plástico, de madeira & 7 & 8 & 15 & 5 & 10 & 15 \\
\hline Pentes, escovas de cabelo & 0 & 2 & 2 & 3 & 0 & 3 \\
\hline Potes para guardar lápis e giz de cera & 0 & 0 & 0 & 1 & 0 & 1 \\
\hline Quebra-cabeças & 1 & 2 & 3 & 0 & 0 & 0 \\
\hline Recipiente para guardar peças tipo Lego & 0 & 1 & 1 & 3 & 0 & 3 \\
\hline Relógio-despertador de mesa & 0 & 1 & 1 & 0 & 0 & 0 \\
\hline Revistas, livros, folhetos de supermercado & 7 & 9 & 16 & 0 & 5 & 5 \\
\hline Sapatinhos de boneca & 1 & 0 & 1 & 0 & 0 & 0 \\
\hline Secadores de cabelo & 0 & 1 & 1 & 1 & 4 & 5 \\
\hline "Sofá" (feito de caixas de leite longa-vida) & 0 & 1 & 1 & 0 & 1 & 1 \\
\hline Tampas de embalagens & 0 & 0 & 0 & 0 & 5 & 5 \\
\hline Telefones, suas partes ou celulares & 2 & 2 & 4 & 1 & 0 & 1 \\
\hline Torneira e pia & 1 & 0 & 1 & 0 & 0 & 0 \\
\hline $\begin{array}{l}\text { Utensílios de cozinha } \\
\text { (panelas, talheres, copos, potes, pratos, } \\
\text { xícaras etc) }\end{array}$ & 15 & 15 & 30 & 1 & 11 & 12 \\
\hline TOTAL & 105 & 99 & 204 & 59 & 78 & 137 \\
\hline
\end{tabular}

A Tabela 23 mostra as freqüências absolutas e relativas de cada uma das categorias de brincadeiras analisadas. Pode-se notar que as ações usuais com objeto corresponderam à metade do total de eventos registrados $(50,62 \%)$.

Tabela 23 - Freqüências absolutas $(\mathrm{Fa})$ e relativas $(\mathrm{Fr})$ das categorias de brincadeiras analisadas, obtidas nos focais do último semestre, com valores separados para as meninas (Sf) e para os meninos $(\mathrm{Sm})$ como sujeitos-focais.

\begin{tabular}{l|c|c|c|c|c|c}
\hline \multirow{2}{*}{ Categorias de brincaeiras } & \multicolumn{2}{|c|}{ Sf } & \multicolumn{2}{c|}{ Sm } & \multicolumn{2}{c}{ Total } \\
\cline { 2 - 7 } & $\mathrm{Fa}$ & $\mathrm{Fr}(\%)$ & $\mathrm{Fa}$ & $\mathrm{Fr}(\%)$ & $\mathrm{Fa}^{1}$ & $\mathrm{Fr}(\%)$ \\
\hline Ação usual com objeto & 105 & 51,47 & 99 & 48,53 & 204 & 50,62 \\
\hline Ação não usual com objeto & 59 & 43,07 & 78 & 56,93 & 137 & 34,00 \\
\hline Ações sem objeto $^{\text {TOTAL }}{ }^{2}$ & 38 & 61,29 & 24 & 38,71 & 62 & 15,38 \\
\hline
\end{tabular}

Nota: 1) Total de cada categoria de brincadeiras;

2) Total de brincadeiras por gênero e total final (soma).

A análise estatística dos dados mostrou que a diferença entre os totais das categorias de brincadeiras foi significativa $\left(\chi^{2}=75,132, \mathrm{gl}=2, \mathrm{p}=0\right)$. Ou seja, em geral, nos focais do 
último semestre, as crianças brincaram mais freqüentemente de modo usual com os objetos do que de modo não-usual, e brincaram mais com objetos do que sem eles (Figura 28).

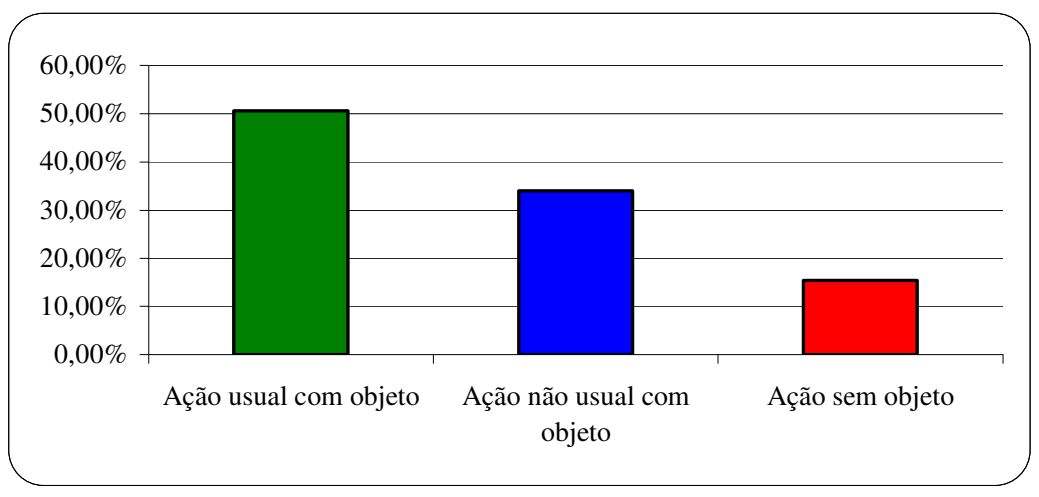

Figura 28 - Comparação das freqüências relativas das categorias de brincadeiras analisadas nos focais do último semestre.

Quando se considera as distinções entre meninos e meninas (Tabela 22), as diferenças mais marcantes (diferença $\geq$ três eventos) foram: a) As meninas brincaram mais do que os meninos de modo usual com os objetos: alimentos; bonecas; cestas de plástico; e ferro de passar roupas; b) Os meninos brincaram mais do que as meninas de forma usual com os objetos: brinquedo chamado "pipoquinha"; e carrinhos; c) As meninas brincaram mais do que os meninos de modo não-usual com os objetos: pentes e escovas de cabelo; e recipiente para guardar peças tipo Lego; d) Os meninos brincaram mais do que as meninas de forma nãousual com os objetos: peças de plástico ou de madeira; revistas, livros e folhetos de supermercado; tampas de embalagens; e utensílios de cozinha. É interessante observar que os meninos brincaram mais de modo não-usual com os objetos do que as meninas, tanto quando se considera a quantidade de objetos diversos quanto em relação ao total de brincadeiras nãousuais (Tabelas 22 e 23; Figura 29). 


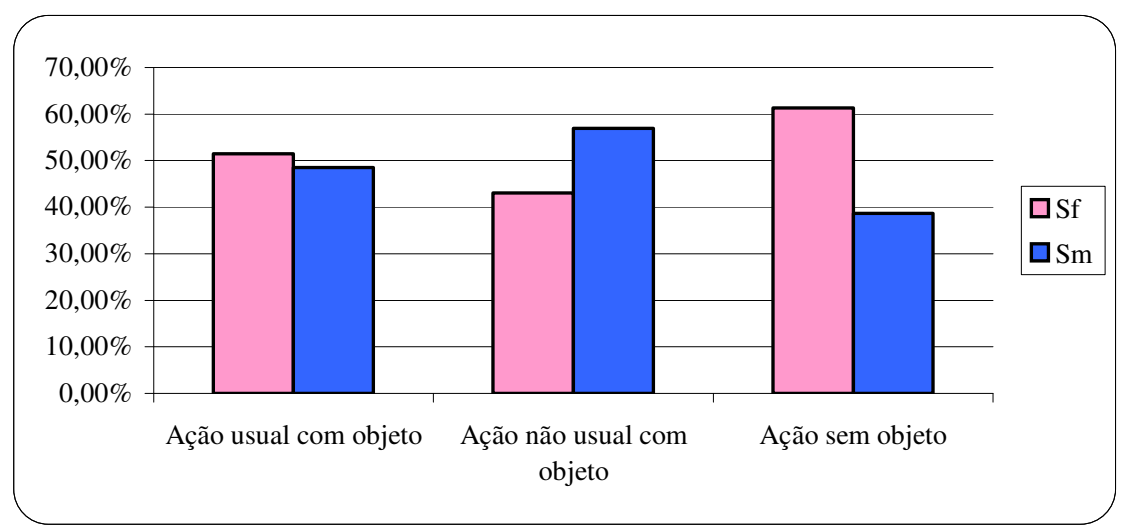

Figura 29 - Freqüências relativas das categorias de brincadeiras analisadas nos focais do último semestre, comparando-se os valores obtidos para os sujeitos-focais do sexo feminino (Sf) e masculino (Sm).

Submetendo-se estes dados à análise estatística (Tabela 24), obteve-se que houve associação significativa entre o tipo de ação (brincadeira) e o gênero (sexo) das crianças $\left(\chi^{2}=\right.$ $5,970, \mathrm{gl}=2, \mathrm{p}=0,051)$. No entanto, apenas para as ações não-usuais com objeto é que a freqüência para os meninos foi significativamente maior do que aquela para as meninas (resíduos ajustados iguais a, respectivamente, 2,0 e -2,0).

Tabela 24 - Distribuição das categorias de brincadeiras, obtidas nos focais do último semestre, em relação ao gênero (sexo) das crianças.

\begin{tabular}{|c|c|c|c|c|c|}
\hline \multicolumn{6}{|c|}{ Ação * Sexo Crosstabulation } \\
\hline & & & \multicolumn{2}{|c|}{ Sexo } & \multirow[b]{2}{*}{ Total } \\
\hline & & & Feminino & Masculino & \\
\hline \multirow[t]{18}{*}{ Ação } & \multirow[t]{6}{*}{ Ação usual com objeto } & Count & 105 & 99 & 204 \\
\hline & & Expected Count & 102,3 & 101,7 & 204,0 \\
\hline & & \% within Ação & $51,5 \%$ & $48,5 \%$ & $100,0 \%$ \\
\hline & & $\%$ within Sexo & $52,0 \%$ & $49,3 \%$ & $50,6 \%$ \\
\hline & & $\%$ of Total & $26,1 \%$ & $24,6 \%$ & $50,6 \%$ \\
\hline & & Adjusted Residual &, 5 &,- 5 & \\
\hline & \multirow{6}{*}{$\begin{array}{l}\text { Ação não-usual com } \\
\text { objeto }\end{array}$} & Count & 59 & 78 & 137 \\
\hline & & Expected Count & 68,7 & 68,3 & 137,0 \\
\hline & & \% within Ação & $43,1 \%$ & $56,9 \%$ & $100,0 \%$ \\
\hline & & $\%$ within Sexo & $29,2 \%$ & $38,8 \%$ & $34,0 \%$ \\
\hline & & $\%$ of Total & $14,6 \%$ & $19,4 \%$ & $34,0 \%$ \\
\hline & & Adjusted Residual & $-2,0$ & 2,0 & \\
\hline & \multirow[t]{6}{*}{ Ação sem objeto } & Count & 38 & 24 & 62 \\
\hline & & Expected Count & 31,1 & 30,9 & 62,0 \\
\hline & & \% within Ação & $61,3 \%$ & $38,7 \%$ & $100,0 \%$ \\
\hline & & $\%$ within Sexo & $18,8 \%$ & $11,9 \%$ & $15,4 \%$ \\
\hline & & $\%$ of Total & $9,4 \%$ & $6,0 \%$ & $15,4 \%$ \\
\hline & & Adjusted Residual & 1,9 & $-1,9$ & \\
\hline \multirow{5}{*}{\multicolumn{2}{|c|}{ Total }} & Count & 202 & 201 & 403 \\
\hline & & Expected Count & 202,0 & 201,0 & 403,0 \\
\hline & & \% within Ação & $50,1 \%$ & $49,9 \%$ & $100,0 \%$ \\
\hline & & $\%$ within Sexo & $100,0 \%$ & $100,0 \%$ & $100,0 \%$ \\
\hline & & $\%$ of Total & $50,1 \%$ & $49,9 \%$ & $100,0 \%$ \\
\hline
\end{tabular}


Portanto, embora o número total de brincadeiras das categorias analisadas tenha sido praticamente o mesmo para os dois gêneros, os meninos utilizaram os objetos de modos mais distintos de como se costuma usá-los do que as meninas. Além disso, enquanto os meninos brincaram bastante com objetos culturalmente de uso mais masculino, como os carrinhos, e as meninas brincaram bastante com objetos de uso culturalmente feminino, como bonecas, ambos brincaram na mesma proporção, de modo usual, com utensílios de cozinha, mas os meninos brincaram 10 vezes a mais do que as meninas com estes objetos, de modo não-usual.

Sem prejuízo da compreensão das diferenças significativas encontradas em função da brincadeira com objetos ser ou não usual, deve-se notar que os dois tipos de brincadeira ocorrem de maneira consistente. Registram-se também as brincadeiras sem objetos, com certa tendência maior entre as meninas (resíduo ajustado=1,9; Tabela 24). A forte presença de ações envolvendo objetos é compatível com a noção de desenvolvimento característico dessa fase, na qual as crianças apresentam a chamada intersubjetividade primária (nos termos de Trevarthen, 1984 apud Bussab,2003), ou a capacidade de compartilhar a atenção de um parceiro em torno de objetos (nos termos de Tomasello, 2003). A brincadeira com objetos revela-se como potencialmente associada à criação/recriação e manutenção da microcultura, associável a ganhos de significado (nos termos de Boesch, 2001). É interessante notar uma certa interação dos fatores gênero e tipo de ação: mais usuais com relação aos objetos típicos entre as meninas e entre os meninos e mais não-usais quando os meninos usam objetos tipicamente femininos. Ações sem objeto também são compartilhadas. 


\section{9.- Imitação de ações usuais ou não-usuais com objeto e de ações sem objeto}

O objetivo de se estudar "imitação" neste trabalho foi o de verificar o seu papel nas interações sociais das crianças de 1 a 3 anos de idade. $\mathrm{O}$ sentido de imitação adotado foi o mais amplo possível, ou seja, "fazer (ou tentar fazer) o mesmo que o outro", embora também possa englobar episódios de imitação num sentido mais restrito, como a compreensão de um processo com início, meio e fim. Segundo Pedrosa e Eckerman (2000) a imitação é uma das formas de ações coletivas por meio das quais as crianças compartilham significados. Eckerman, Davis e Didow (1989) e Eckerman e Didow (1996) notaram que a imitação é um modo de promover ou manter a interação entre as crianças e o brincar junto. Fiamenghi (1999) afirma que a imitação "permite a uma das crianças perceber que o parceiro comunicativo está interessado nela e, assim, a responder a esse convite para comunicar-se" (pp. 42). Já a imitação como mecanismo de aprendizagem social requer que o sujeito que reproduz a estratégia comportamental ou o comportamento do demonstrador reconheça-o como um agente intencional/mental igual a si próprio (Tomasello, 2003). Este mesmo autor chama as crianças de 1 a 3 anos de “'máquinas de imitação', já que sua resposta natural a muitas situações é fazer o que estão fazendo as pessoas à sua volta e, na verdade, o que criam individualmente por conta própria é muito limitado na maioria das situações” (pp. 72).

A análise a seguir foi feita com o intuito de acompanhar a imitação durante o desenvolvimento das crianças em cinco momentos diferentes do período de coleta de dados focais iniciais, intermediários e finais, duplas iniciais e finais - procurando identificar as possíveis funções da imitação no grupo de crianças estudado e verificar se havia diferença na freqüência de imitação entre a situação em que as crianças estavam com outras no grupo (focais) e aquela em que elas estavam em díades. Os dados foram analisados segundo a imitação de três tipos de ações - ação usual com o objeto; ação não-usual com o objeto; e 
ação sem objeto -, o tipo de brincadeira antes da imitação (conjunta ou solitária), a ocorrência de interação social logo após a imitação e a repetição da ação imitada (pela criança que imitou) na mesma sessão, em outro episódio e/ou num outro dia.

A Tabela 25 apresenta os valores absolutos e relativos obtidos para cada uma das variáveis estudadas.

\section{Resultados}

Tabela 25 - Freqüências absolutas e totais de cada categoria de brincadeira analisada em cada fase (focais e duplas). OBS.: Foram analisadas apenas as duplas que se repetiram no primeiro (duplas iniciais) e no segundo semestre (duplas finais): A-C, A-Gi, A-H, A-La, C-Gi, C-H, C-S, GiGu, Gi-H, Gi-La,Gu-H, H-S e La-S.

\begin{tabular}{l|l|c|c|c|c|c}
\hline Brincadeiras & Freqüência & $\begin{array}{c}\text { Focais } \\
\text { iniciais }\end{array}$ & $\begin{array}{c}\text { Focais } \\
\text { intermediários }\end{array}$ & $\begin{array}{c}\text { Focais } \\
\text { finais }\end{array}$ & $\begin{array}{c}\text { Duplas } \\
\text { iniciais }\end{array}$ & $\begin{array}{c}\text { Duplas } \\
\text { finais }\end{array}$ \\
\hline $\begin{array}{l}\text { Ação usual } \\
\text { com objeto }\end{array}$ & $\mathrm{Fa}$ & 3 & 4 & 4 & 23 & 15 \\
\cline { 2 - 7 } & $\mathrm{Fr}(\%)$ & 9,7 & 19,1 & 11,2 & 48,9 & 22,4 \\
\hline $\begin{array}{l}\text { Ação não- } \\
\text { usual com } \\
\text { objeto }\end{array}$ & $\mathrm{Fa}$ & 5 & 9 & 9 & 14 & 36 \\
\cline { 2 - 7 } & $\mathrm{Fr}(\%)$ & 16,1 & 42,9 & 25 & 29,8 & 53,7 \\
\hline $\begin{array}{l}\text { Ação sem } \\
\text { objeto }\end{array}$ & $\mathrm{Fa}$ & 23 & 8 & 23 & 10 & 16 \\
\hline $\begin{array}{ll}\text { Interação } \\
\text { social após } \\
\text { imitação }\end{array}$ & $\mathrm{Fa}(\%)$ & 74,2 & 38,1 & 63,9 & 21,3 & 23,9 \\
\cline { 2 - 7 } & $\mathrm{Fr}(\%)$ & 51,6 & 57,1 & 77,8 & 55,3 & 52,2 \\
\hline
\end{tabular}

Em termos do número total de episódios de imitação registrados, os focais iniciais e os finais tiveram valores semelhantes (31 e 36, respectivamente), enquanto nos focais intermediários houve um menor número de imitações (21). Nas sessões de duplas, o total de imitações foi mais elevado - 47 nas iniciais e 67 nas finais - mesmo considerando que o intervalo de tempo analisado nas duplas (130 minutos nas iniciais e 150 minutos nas finais) é maior do que aquele dos focais (120 minutos), pois o valor médio de imitações nos focais foi 
de 29,3, e o esperado para as duplas iniciais seria de 31,7 e, para as finais, de 36,6. Parece, então, que a situação de duplas favorece a ocorrência de imitações, por estar limitada a duas crianças brincando com 10 pares de objetos iguais ou semelhantes, numa sala praticamente isolada de interferências externas. Além disso, pode-se observar que os focais iniciais e os finais tiveram um predomínio de imitações de ações sem objeto $(74,2 \%$ nos focais iniciais e 63,9\% nos focais finais). Nos focais intermediários, as imitações de ações não-usuais com objeto e de ações sem objeto tiveram quase a mesma freqüência (42,9\% e 38,1\%, respectivamente), que foi quase o dobro da frequiência de imitações de ações usuais com objeto $(19,1 \%)$. Nas duplas iniciais, as ações usuais com objeto foram imitadas em quase $50 \%$ das vezes, enquanto nas finais, as ações não-usuais com objeto foram aquelas imitadas em um pouco mais da metade dos episódios. Estes resultados indicam que as ações usuais com objeto foram as menos imitadas, talvez por suscitarem menos interesse das crianças, uma vez que são ações mais comumente encontradas e, portanto, que podem ser vistas em outros contextos, fora o do grupo de brinquedo. Como já foi escrito em outra parte, parece que a novidade atrai a atenção das crianças.

Quanto à ocorrência de interação social após a imitação, sua frequiência nos focais finais $(77,8 \%)$ foi maior do que a registrada nos focais iniciais $(51,6 \%)$ e nos focais intermediários $(57,1 \%)$. Já nas duplas, houve ocorrência de interação social após a imitação em um pouco mais de 50\% dos episódios. Submetendo-se estes dados ao teste do Qui-quadrado, observouse que houve diferença significativa para a ocorrência de interação social após imitação entre os períodos $\left(\chi^{2}=14,838, \mathrm{gl}=4, \mathrm{p}=0,005\right)$. Nos focais iniciais e intermediários, os valores de interação social após imitação foram menores do que os esperados, e, nos focais finais e nas duplas, os valores foram maiores do que os esperados. Este resultado indica que no último semestre, período em que foram realizadas as sessões de focais finais e de duplas finais, as crianças estavam utilizando a imitação como um meio para iniciar ou manter interações 
sociais com seus parceiros coetâneos, confirmando a hipótese de que a imitação pode ser uma estratégia para começar ou continuar a relação social entre crianças pequenas, principalmente quando elas estão em idade próxima aos 3 anos. Além disso, nas duplas, a estratégia de imitar o parceiro parece resultar em mais interações sociais do que nos focais ( os focais intermediários e as duplas iniciais ocorreram na mesma época)

Os Apêndices 20, 21, 22, 23 e 24 mostram um detalhamento dos dados analisados. No contexto de brincadeira em grupo, pode-se observar que, nos focais iniciais, nenhuma ação usual com objeto resultou em ocorrência de interação social entre as crianças após a imitação, mas que todas as ações não-usuais com objeto foram seguidas por interação social após a imitação. Nos focais intermediários todas as imitações de ações sem objeto resultaram em interação social. Nos focais finais, cerca de $71 \%$ das interações sociais após imitação foram devidas a ações sem objeto. Nas duplas iniciais, houve um ligeiro predomínio de ocorrência de interações sociais após ações usuais com objeto, enquanto nas duplas finais, este predomínio aconteceu para as brincadeiras não-usuais com objeto. Ou seja, pode-se afirmar que a imitação de ações sem objeto e de ações não-usuais com objeto foi mais atraente para deflagrar interações sociais entre as crianças do que a imitação de ações usuais com objeto.

Em relação à repetição da ação imitada em outro episódio, nota-se (Apêndices 20, 21, 22, 23 e 24) que foi registrada uma única ocorrência nos focais iniciais e nos finais e nenhuma nos focais intermediários e que, tanto nas duplas iniciais quanto nas finais, houve quatro ocorrências. Destas, três foram repetidas num outro dia. Nos focais, somente nos finais uma ação imitada foi repetida num outro dia. Tais resultados podem ser explicados pelo número limitado de objetos nas sessões de duplas (10 pares), o que pode favorecer mais repetições de ações, ao contrário das sessões de focais, que eram realizadas em locais com grande oferta de diferentes objetos. 
Finalmente, analisando-se as sessões conjuntas, apesar de terem sido feitas apenas duas destas sessões (Apêndice 25) houve cinco repetições de ações imitadas pelas crianças durante as sessões de duplas. Tanto estas repetições quanto as descritas no parágrafo anterior sinalizam a presença da persistência de significados construídos entre as crianças.

A análise estatística dos dados dos focais e das duplas (Tabela 26) mostrou que houve associação significativa entre períodos e tipos de ações imitadas $\left(\chi^{2}=51,516, \mathrm{gl}=8, \mathrm{p}=0\right)$. Nos focais iniciais, as freqüências de imitações de ações usuais com objeto e de ações nãousuais foram menores do que as esperadas (resíduos ajustados iguais a, respectivamente, -2,1 e -2,5), enquanto a freqüência de imitações de ações sem objeto foi maior do que a esperada $(4,3)$. Nos focais intermediários, não houve diferença significativa entre os valores obtidos e os esperados. Nos focais finais, a freqüência de imitações de ações usuais com objeto foi menor do que a esperada $(-2,0)$ e a de imitações de ações sem objeto foi maior do que a freqüência esperada $(3,3)$. Nas duplas iniciais, a freqüência de imitações de ações usuais com objeto foi maior do que a esperada $(4,5)$ e a freqüência de imitações de ações sem objeto foi menor do que a esperada $(-2,9)$. Nas duplas finais, a frequiência de imitações de ações nãousuais com objeto foi maior do que a esperada $(3,7)$ e a freqüência de imitações de ações sem objeto foi menor do que a esperada $(-3,2)$. Ao que parece, a partir destes resultados, a situação de duplas "favoreceu" a imitação de ações com objeto e, por outro lado, a situação de grupo (focais) foi mais propícia à imitação de ações sem objeto. 
Tabela 26 - Distribuição das categorias de imitação obtidas nos focais iniciais (21/8/03 a $22 / 9 / 03)$, intermediários (25/3/04 a 28/4/04) e finais (13/10/04 a 16/11/04) e duplas iniciais e finais.

Períodos * Imitação Crosstabulation

\begin{tabular}{|c|c|c|c|c|c|c|}
\hline & & & & Imitação & & \\
\hline & & & $\begin{array}{l}\text { Ação usual } \\
\text { com objeto }\end{array}$ & $\begin{array}{c}\text { Ação } \\
\text { não-usual } \\
\text { com objeto }\end{array}$ & $\begin{array}{l}\text { Ação sem } \\
\text { objeto }\end{array}$ & Total \\
\hline Períodos & Focais iniciais & Count & 3 & 5 & 23 & 31 \\
\hline & & Expected Count & 7,5 & 11,2 & 12,3 & 31,0 \\
\hline & & $\%$ within Períodos & $9,7 \%$ & $16,1 \%$ & $74,2 \%$ & $100,0 \%$ \\
\hline & & Adjusted Residual & $-2,1$ & $-2,5$ & 4,3 & \\
\hline & Focais intermediários & Count & 4 & 9 & 8 & 21 \\
\hline & & Expected Count & 5,1 & 7,6 & 8,3 & 21,0 \\
\hline & & $\%$ within Períodos & $19,0 \%$ & $42,9 \%$ & $38,1 \%$ & $100,0 \%$ \\
\hline & & Adjusted Residual &,- 6 & ,7 &,- 1 & \\
\hline & Focais finais & Count & 4 & 9 & 23 & 36 \\
\hline & & Expected Count & 8,7 & 13,0 & 14,3 & 36,0 \\
\hline & & $\%$ within Períodos & $11,1 \%$ & $25,0 \%$ & $63,9 \%$ & $100,0 \%$ \\
\hline & & Adjusted Residual & $-2,0$ & $-1,5$ & 3,3 & \\
\hline & Duplas iniciais & Count & 23 & 14 & 10 & 47 \\
\hline & & Expected Count & 11,4 & 17,0 & 18,6 & 47,0 \\
\hline & & $\%$ within Períodos & $48,9 \%$ & $29,8 \%$ & $21,3 \%$ & $100,0 \%$ \\
\hline & & Adjusted Residual & 4,5 & $-1,0$ & $-2,9$ & \\
\hline & Duplas finais & Count & 15 & 36 & 16 & 67 \\
\hline & & Expected Count & 16,3 & 24,2 & 26,5 & 67,0 \\
\hline & & $\%$ within Períodos & $22,4 \%$ & $53,7 \%$ & $23,9 \%$ & $100,0 \%$ \\
\hline & & Adjusted Residual &,- 4 & 3,7 & $-3,2$ & \\
\hline Total & & Count & 49 & 73 & 80 & 202 \\
\hline & & Expected Count & 49,0 & 73,0 & 80,0 & 202,0 \\
\hline & & $\%$ within Períodos & $24,3 \%$ & $36,1 \%$ & $39,6 \%$ & $100,0 \%$ \\
\hline
\end{tabular}




\subsection{0- Resumo das análises realizadas}

5.1- Análise da frequiência de comunicação verbal e não-verbal, no começo e no final do primeiro semestre

Período: $1^{\circ}$ semestre de observações (agosto a dezembro de 2003);

Análise: cinco primeiros focais e cinco últimos focais de cada criança;

Sujeitos: A, C, Gi, H, La e S;

Idades: 14 a 22 meses (início) e 18 a 26 meses (fim).

\section{2- Orientação da atenção e afinidade social}

Período: março e novembro de 2004;

Análise: 11 duplas da $1^{\mathrm{a}}$ fase e 12 duplas da $6^{\mathrm{a}}$ fase;

Sujeitos: A, B, C, Gi, Gu, H, La, Li e S;

Idades: 21 a 29 meses ( $1^{\mathrm{a}}$ fase) e 30 a 37 meses ( $6^{\mathrm{a}}$ fase).

\section{3- Análise complementar do comportamento não-verbal}

Período: 21/8-22/9/03; 25/3-28/4/04; 13/10-16/11/04;

Análise: focais (quatro primeiros, quatro intermediários e quatro últimos, de cada criança que permaneceu no grupo do início ao fim da coleta de dados);

Sujeitos: A, C, Gi, H, La e S;

Idades: 14 a 22 meses (início), 21 a 29 meses (meio), 28 a 36 meses.

\section{4.- Análise da comunicação verbal}

Período: 21/8-22/9/03; 25/3-28/4/04; 13/10-16/11/04;

Análise: focais (quatro primeiros, quatro intermediários e quatro últimos, de cada criança que permaneceu no grupo do início ao fim da coleta de dados);

Sujeitos: A, C, Gi, H, La e S;

Idades: 14 a 22 meses (início), 21 a 29 meses (meio), 28 a 36 meses (fim).

\section{5.- Persistência de significados construídos no grupo}

Período: $3^{\circ}$ semestre de observações (julho a dezembro de 2004);

Análise: todos os focais, última sessão de cada díade antes das sessões conjuntas e as duas sessões conjuntas;

Sujeitos: A, B, C, Gi, Gu, H, La, Li e S;

Idades: 24 a 31 meses (início), 30 a 38 meses (fim). 
5.6- Tipos de brincadeiras e efeitos do grau de preferência social e do distanciamento de idades

Período: julho, setembro e novembro de 2004;

Análise: última sessão de cada díade antes das sessões conjuntas;

Sujeitos: A, B, C, Gi, Gu, H, La, Li e S;

Idades: 24 a 31 meses (início), 29 a 37 meses (fim).

5.7- Análise do brincar, das parcerias preferenciais e da forma de comunicação (verbal ou ausência de verbal)

Período: 21/8-22/9/03; 25/3-28/4/04; 13/10-16/11/04;

Análise: focais (quatro primeiros, quatro intermediários e quatro últimos, de cada criança que permaneceu no grupo do início ao fim da coleta de dados);

Sujeitos: A, C, Gi, H, La e S;

Idades: 14 a 22 meses (início), 21 a 29 meses (meio), 28 a 36 meses (fim).

5.8.- Brincadeiras usuais ou não-usuais com objeto e brincadeiras sem objeto

Período: $3^{0}$ semestre de observações (julho a dezembro de 2004);

Análise: todos os focais;

Sujeitos: A, B, C, Gi, Gu, H, La, Li e S;

Idades: 24 a 31 meses (início), 29 a 37 meses (fim).

5.9.- Imitação de ações usuais ou não-usuais com objeto e de ações sem objeto

Período: $1^{\circ}, 2^{\circ}$ e $3^{\circ}$ semestres de observações (agosto de 2003 a dezembro de 2004);

Análise: focais (quatro primeiros, quatro intermediários e quatro últimos, de cada criança que permaneceu no grupo do início ao fim da coleta de dados); duplas iniciais e duplas finais;

Sujeitos: A, B, C, Gi, Gu, H, La, Li e S;

Idades: 14 a 22 meses (início), 29 a 37 meses (fim). 


\section{6- DISCUSSÃO GERAL DOS RESULTADOS}

Ao longo deste trabalho, foram analisadas diferentes características da comunicação e interação social do grupo de crianças observado. Cabe, nesta seção, relacionar os resultados obtidos em cada tipo de análise e ilustrar alguns aspectos mais relevantes de maneira qualitativa.

\section{1.- Comunicação}

No item 5.1 foi feita uma primeira tentativa de analisar a comunicação que ocorria entre as crianças. Verificou-se que houve um aumento significativo na freqüência de comunicação não-verbal via "atenção" e uma diminuição significativa nas freqüências de “expressões faciais" e "variações de postura", entre os períodos inicial e final analisados $\left(1^{\circ}\right.$ semestre de coleta de dados). Destacou-se o predomínio dos eventos de "atenção", que corresponderam a 47\% da comunicação não-verbal, no período inicial, e a 59\%, no período final. Quanto à proporção entre comunicação verbal e não-verbal, elas foram semelhantes nos dois períodos analisados: apenas $9 \%$ dos eventos comunicativos foram verbais (e $91 \%$ nãoverbais), no período inicial, e, no final, 7\% destes eventos foram verbais (e 93\% não-verbais). Ou seja, as crianças comunicaram-se essencialmente de modo não-verbal. O intervalo entre os períodos inicial e final ( 3 meses), no entanto, pode não ter sido suficiente para detectar alterações no modo de comunicação. Além disso, as educadoras e a pesquisadora foram consideradas enquanto emissoras e receptoras de sinais comunicativos para as crianças. Nas análises realizadas posteriormente, procurou-se evitar a inclusão dos adultos nos registros ou delimitar exatamente o número de comportamentos dirigidos a eles (e sem considerar os emitidos por eles), uma vez que o foco da pesquisa estava na interação criança-criança. 
A análise anterior evidenciou a importância da atenção nas interações sociais e comunicativas. A partir daí, foram criadas categorias de orientação da atenção (item 5.2). Os resultados mostraram que "atenção para objetos ou aspectos do ambiente diferentes" e "atenção unilateral" foram as categorias mais freqüentes para as duplas de crianças selecionadas (situação semicontrolada). Comparando-se as duplas quanto à afinidade social, concluiu-se que as duplas com maior afinidade apresentaram freqüências significativamente maiores do que as esperadas nas categorias de "atenção conjunta" e "atenção para objetos iguais ou semelhantes", do que as duplas com menor afinidade social. A atenção conjunta consiste na atenção coordenada de pelo menos duas pessoas em relação a um mesmo foco de interesse (Bussab, Pedrosa e Carvalho, 2007) e, segundo Tomasello (2003), ela constitui a base para a aprendizagem da linguagem e da cultura pela criança, porque pressupõe o entendimento dos outros como seres intencionais iguais a ela própria. Ao estabelecer uma mesma referência externa entre dois ou mais sujeitos, a atenção conjunta possibilita o compartilhamento de significados entre os "participantes" da situação. O fato da atenção conjunta ter ocorrido mais nas duplas de crianças com maior afinidade social indica que a transmissão cultural pode ser favorecida por relações sociais mais próximas entre as pessoas (pelo menos na primeira infância).

Alguns comportamentos que denotam uma intenção para compartilhar a atenção são os gestos dêicticos ${ }^{14}$, como apontar ou segurar um objeto para mostrá-lo para outra pessoa, que podem ser tanto imperativos (para satisfazer alguma vontade ou necessidade da criança) quanto declarativos (para fazer o outro prestar atenção no mesmo aspecto do ambiente que está sendo foco do sujeito) - Tomasello (2003). Na análise dos comportamentos não-verbias indicativos de comunicação (item 5.3), "apontar" apareceu principalmente nos focais intermediários (10 ocorrências) e "segurar e mostrar um objeto" ocorreu no máximo duas 
vezes em cada período de focais analisados. Em compensação, "estender objeto para" (oferecer) também pode ser interpretado como um gesto dêictico, ou de pedido para atenção conjunta, pois implica em que o sujeito que oferece e aquele que recebe a "oferta" olhem para o objeto oferecido. Este comportamento ocorreu ao todo 42 vezes nos focais analisados. Sabendo-se que a maioria dos comportamentos não-verbais foi dirigida a outras crianças, tais resultados indicam que a atenção conjunta por meio de gestos dêicticos foi um modo utilizado para compartilhamento de significados no grupo de brinquedo, principalmente no período em que as crianças estavam com idades entre 22 e 30 meses (focais intermediários, freqüência de "gestos e acenos" significativamente maior do que a esperada). Além disso, a atenção conjunta é pré-requisito para que ocorra aprendizagem por imitação, um mecanismo eficiente de transmissão cultural. A imitação apareceu com maior frequiência nos focais finais, período em que as crianças estavam com idades entre 28 e 37 meses, mostrando que elas podiam estar mais ativas na produção de processos de microcultura nessa faixa etária.

Um outro dado que merece ser destacado do item 5.3, foi a presença elevada de comunicação via "olhares" (em torno de 25\%), nos três períodos de focais medidos, o que confirma o resultado da primeira análise feita sobre a comunicação (item 5.1), na qual houve prevalência das categorias atencionais.

O período em que as crianças aumentaram a frequiência de comunicação através de "gestos e acenos" coincidiu com aquele em que elas verbalizaram mais (focais intermediários), como foi constatado nos itens 5.4 e 5.7. Considerando que "gestos e acenos" é a categoria mais representacional e simbólica dentre as não-verbais analisadas, estes resultados sugerem que as crianças estavam aumentando sua capacidade de simbolizar na faixa etária de 22 a 36 meses, hipótese fortalecida pela freqüência significativamente maior do

\footnotetext{
14 "Dêictico" relaciona-se com a palavra "dêixis" (exibição). Os pronomes demonstrativos, como "este', "esse" e "aquele", são signos dêicticos porque não significam, apenas mostram, indicam. Os pronomes "eu" e "tu" têm esta mesma natureza. (Michaelis, 1998).
} 
que a esperada de verbalizações para "objetos com os quais a criança estava" ou "que estavam com outras crianças" - comportamento indicativo de brincadeira simbólica ("faz-de-conta").

Uma exemplificação do modo como as crianças se comunicaram não-verbalmente pode ser dada pelos episódios seguintes ${ }^{15}$ :

\section{Focais iniciais (praça, 21/8/03) - "vocalizações no gira-gira":}

A educadora roda o gira-gira com $C$ ( $m, 14$ meses) e $S$ ( $m, 17$ meses) sentados. Os dois se olham e vocalizam de modo alternado e com sintonia. Gi (f, 22meses) aproxima-se e a educadora pára o gira-gira para sentá-la nele também. A educadora volta a impulsionar o gira-gira e $S$ e $C$ voltam a vocalizar; Gi olha para eles e ri; $C$ ri olhando para ela. $S$ tomba a cabeça de lado olhando para $C$. S chacoalha o corpo para cima e para baixo; Gi imita-o e, depois, $C$ imita-os. $C$ fica quieto um pouco, olhando para o chão, depois volta a vocalizar olhando para Gi e S e sorri aberto; Gi ri. C pára e recomeça. A educadora pára de girar, $C$ pára de vocalizar; ela volta a girar e ele volta a vocalizar; Gi ri olhando para $C$ e ele sorri aberto, olhando para ela. De novo, quando o gira pára ou diminui a velocidade, C pára de vocalizar e volta a vocalizar quando a educadora roda o gira. Gi ri duas vezes, C olha para ela e sorri aberto. La (f, 20 meses) aproxima-se e a educadora pára o gira para ela subir; silêncio de $S$, Gi e $C$, que observam a cena. A educadora impulsiona de novo o gira-gira e $C$ recomeça a vocalizar, agora olhando para La. O gira pára e $C$ pára de vocalizar. A educadora volta a girá-lo e $C$ volta a vocalizar. $O$ gira pára e $C$ pára de vocalizar; $a$ educadora dá impulso novamente, porém $C$ fica em silêncio. Então, Gi vocaliza numa entonação parecida com aquela que $C$ vocalizava antes, mas termina em riso. Silêncio. $C$ volta a vocalizar até que La fica de joelhos sobre o assento e o gira pára. A educadora impulsiona-o de novo, Gi vocaliza e ri, depois $S$ vocaliza, depois La, depois La e $S$. C não vocaliza. C observa La tirar as mãos da parte de segurar do gira e movimentá-las no ar (atitude repreendida pela educadora), e sorri aberto. As quatro crianças vocalizam no mesmo ritmo, enquanto a educadora roda o gira. Às vezes, La tira as mãos do gira e olha para $C$, que sorri aberto para ela. A educadora repreende La e pára de girar; as crianças param de vocalizar. Ela volta a rodá-lo e as crianças recomeçam a vocalizar. $C$ cai do assento com o gira quase parado e a educadora volta a sentá-lo. La sai do gira-gira, depois $S$ sai, depois Gi. C vocaliza sozinho, com o gira parado (da mesma forma que vocalizava quando ele estava em movimento), enquanto a educadora, Gi e La ainda estão perto.

O episódio acima mostra como as crianças compartilharam um significado mediado de maneira exclusivamente não-verbal: uma criança, $C$, começou sintonizando suas vocalizações com o movimento do gira-gira e as outras perceberam isto e passaram a imitá-lo, vocalizando quando a educadora impulsionava o gira. É interessante notar que Gi começou a vocalizar

\footnotetext{
${ }^{15}$ Gênero das crianças: "m" = masculino; "f" = feminino.
} 
quando C deixou de fazê-lo com o gira em movimento. É como se ela estivesse demonstrando que entendeu o "código" criado por C e o estivesse chamando de novo para a brincadeira, que ela parece ter achado divertida, de acordo com seus risos para C. Depois, as quatro crianças vocalizam juntas, no mesmo ritmo, enquanto o gira-gira está rodando. No fim, Gi, S e La saem do gira-gira e C fica sentado lá, sozinho, com o gira parado; então, ele vocaliza como estava fazendo quando o gira-gira estava em movimento, como se quisesse chamar as outras crianças (e a educadora), que ainda estavam próximas. Além disso, as crianças apresentaram outros comportamentos não-verbais indicativos de comunicação, como olhares, risos, sorrisos, movimentos do corpo e imitação.

\section{Focais iniciais (cimentado, 22/9/03) - "bater embalagem no chão":}

Gi (f, 21 meses) e La (f, 21 meses) estão sentadas no chão, quase de frente uma para a outra e próximas. Gi segura uma embalagem de xampu, bate-a no chão e vocaliza no mesmo ritmo. Às vezes ela olha para La. C (m, 15 meses), segura uma embalagem igual a de Gi numa mão e outra de desodorante na outra mão, coloca esta na boca e observa Gi por alguns segundos. Gi pára de bater a embalagem e risca/raspa-a no chão num semicírculo. Depois, segura-a com as duas mãos, chacoalha-a e olha para La (e La para ela). Volta a batê-la no chão e a vocalizar; parece que o barulho atrai $S$ ( $m, 18$ meses), que se aproxima e fica olhando para ela. Gi vira a cabeça e olha para ele, mas continua o que estava fazendo. Depois, levanta-se, olha para $S$, que olha para Gi, abre os braços e parece que fala "acabou?"; Gi volta a se sentar e a bater a embalagem no chão, vocalizando. La levanta-se e afasta-se. S agacha-se e observa Gi mais de perto, Gi olha para ele e ele sorri fechado. Gi pára de bater a embalagem e $S$ vocaliza e bate as mãos no chão; Gi fica mexendo na embalagem e observando $S$. Ele senta-se ao lado dela. Gi abre a embalagem e $S$ bate as mãos nas próprias pernas. Gi mexe na tampa do xampu e, às vezes, olha para $S$ que se inclinou em direção a ela para ver melhor o q ela estava fazendo. Depois, ele endireita o corpo e puxa uma mão de Gi; ela olha para ele e volta a segurar a embalagem (se desvencilha da mão de $S$ ). S continua observando Gi a mexer na tampa da embalagem, mas logo ela pára e volta a bater a embalagem no chão e a vocalizar, olhando para $S$ (ele sorri fechado). Depois, balança a embalagem e continua vocalizando no mesmo ritmo e olhando para $S$. Gi volta a mexer na tampa e $S$ estende um braço em direção à mão dela, porém não chega a encostá-la. Gi continua a mexer na tampa e $S$ a observá-la por mais alguns segundos; aí ela recomeça a bater a embalagem no chão e a vocalizar; olha para $S$, ele sorri fechado, ela pára, mexe na tampa e recomeça a bater e a vocalizar. Pára, sorri aberto finalizando a "cantoria" e olhando para $S$, mexe na tampa e recomeça; não olha para $S$. Pára e mexe na tampa; $H$ ( $m, 21$ meses) passa, observa-a e vai embora. Gi volta a bater a embalagem e a vocalizar, olhando para S. Ela pára, os dois ficam se olhando e $S$ tenta encostar a mão na cabeça de Gi. Ela afasta um pouquinho a cabeça e parece que faz cara de zangada. Mexe na tampa e volta a bater a embalagem e a vocalizar; $S$ continua a observá-la. Ela pára e bate a embalagem com as duas mãos; pára e segura a 
embalagem no chão; $S$ bate as mãos nas próprias pernas. Gi bate com as mãos na embalagem sobre o chão e $S$ distrai-se com alguma coisa muito pequena que encontra no chão (talvez parte de uma planta). Gi olha em direção à educadora (que estava falando com C), deixa a embalagem no chão e sai correndo em direção a eles.

O que é interessante destacar neste episódio são as demonstrações de interesse de S em relação a Gi, via observação, alteração da posição do corpo (agachar-se para ver melhor), alteração da postura (inclinar-se em direção a ela), aproximação e sorrisos. Parece que a atenção e o interesse de S sustentaram a atividade de Gi. Estabeleceu-se entre eles um jogo de olhares recíprocos que os manteve em interação um com o outro. S também tentou se comunicar espelhando o movimento de Gi quando ela parou de bater a embalagem no chão: como estava sem embalagem, ele bateu as mãos no chão do mesmo jeito que ela fez com o objeto, como se estivesse pedindo para ela continuar. Outra forma dele pedir para Gi continuar a atividade foi puxando a mão dela ou tentando encostar a sua na dela, como se estivesse tentando chamar sua atenção. S, em geral, foi bem sucedido em sua comunicação não-verbal e Gi atendeu a seus pedidos.

\section{Focais finais (sala do Lilás, 15/9/04) - "bate-bate e silêncio":}

$C$ ( $m, 27$ meses) vai brincar de carrinho com $H$ ( $m, 34$ meses) e La ( $f, 33$ meses) que estavam friccionando carros sobre a mesa, batendo-os um de frente para o outro e fazendo barulho. Num momento La fala "parou" e todos param e esperam. Depois $H$ e La voltam a movimentar os carros, C faz sinal de "psiu" (silêncio) com o dedo indicador erguido próximo à boca, eles param, depois recomeçam; H faz sinal de "psiu" igual a C (imita-o), os três param, recomeçam, depois La faz o mesmo sinal (imita-os) e assim continua a brincadeira.

Este episódio mostra o uso de um gesto simbólico que os participantes conheciam o significado. Inicialmente La falou "parou" e as crianças pararam de bater um carro no outro e fazer barulho. Então, C utilizou o gesto de silêncio e La e H entenderam que era para pararem. Depois, H imitou C, e La imitou C e H, havendo alternância de papéis e persistência de significados. Na verdade, uma análise mais apurada permite que se conclua que o sinal de 
silêncio feito por $\mathrm{C}$ tinha um sentido a mais do que o culturalmente conhecido de "pedir silêncio", pois as crianças paravam de fazer suas ações (bater um carrinho no outro), em vez de modificá-las para não fazer barulho. O uso do gesto de "psiu" já havia sido feito durante uma dupla de A e C com o sentido estrito de pedir silêncio: uma das crianças fazia barulho com um chocalho, e a outra fazia sinal de "psiu"; isto se repetia algumas vezes, até que trocavam de papéis - a criança que antes pedia silêncio, passava a fazer barulho com o chocalho e a outra fazia o sinal de "psiu"para ela parar.

A explicação, dada no item 5.4, de que as crianças emitiram verbalizações acompanhadas de comportamentos não-verbais somente para outras crianças e não para adultos (focais finais) porque ainda não dominavam completamente o código verbal naquela faixa etária, pode ser ilustrada pelos episódios a seguir:

\section{Duplas ( ${ }^{\mathrm{a}}$ fase, 10/3/04) - H-S:}

$H$ (m, 28 meses) pega a lanterna de $S$ (m, 23 meses). $S$ procura por outra lanterna e a encontra, mas ela está apagada. Pede para $H$ acendê-la (pois $S$ não sabe), porém fala "apaga" em vez de "acende". H dá sua lanterna para $S$ e acende a outra. Os dois ficam brincando de iluminar objetos com a lanterna, primeiro lado a lado, depois mais distantes.

\section{Duplas (1ª fase, 11/3/04) - C-S:}

$S$ ( $m, 24$ meses) ilumina a parede. $C$ (m, 21 meses) vocaliza e levanta o braço com a lanterna. $S$ tenta imitá-lo. $C$ faz isto de novo, perto da parede. Vocaliza ou fala algo e $S$ imita-o. C levanta o braço com a lanterna e vocaliza. Depois, ilumina parede e $S$ fala para ele "apaga, apaga, apaga", apontando para a lanterna de C. C não o obedece. S apaga a sua lanterna. $C$ afasta-se, levanta o braço segurando a lanterna e vocaliza. Depois, aproxima-se de $S$.

\section{Duplas (1 ${ }^{\text {a }}$ fase, 11/3/04) - La-S:}

La (f, 27 meses) pega lanterna, acende-a e levanta-a para cima; $S$ (m, 24 meses) imita La. $S$ aproxima-se de La e diz "apaga", mexendo em sua lanterna e aproximando-a de La, que olha a lanterna de $S$ e parece não entender o que ele quer (a lanterna dele estava com a luz apagada). S aperta de leve o braço de La e ela pega a lanterna dele e sai andando com as duas lanternas. $S$ vai atrás dela, La vocaliza "óh", levantando a lanterna dela acesa, e S fala 
"Laura... apaga", enquanto tenta pegar sua lanterna de volta. La não devolve a lanterna para ele (fala algo que não entendo).

Nos três episódios anteriores, fica claro que $\mathrm{S}$ parecia estar meio confuso quanto ao uso da palavra "apaga". Quando em dupla com H, ele falou "apaga", mas queria que H acendesse sua lanterna. Não dá para saber se $\mathrm{H}$ entendeu realmente o pedido de $\mathrm{S}$, pois ele trocou sua lanterna com $S$ (em vez de acender a lanterna de $S$ ). De qualquer forma, $S$ teve seu desejo atendido. Quando em dupla com C, S usou a palavra "apaga" no contexto correto, porém C não o obedeceu. No entanto, quando em dupla com La, S pediu para ela acender a lanterna dele com a palavra "apaga", de novo, e La parece não ter entendido o que S queria.

\section{Duplas (6a fase, 30/11/04) - A-Li - "brincando de entrar na caixa":}

A ( $f, 33$ meses) entra numa caixa e Li (f, 34 meses) também; A ajuda-a a entrar. A senta no fundo e ajuda Li a sentar. Li fala "a gente tamos presa, né, Alice?". A olha para a câmera e faz sinal de silêncio com o dedo indicador (como Li fez antes no episódio). Li diz para A pegar outra caixa e ela fala "não, obrigado", mas sai da caixa e pega a outra dizendo que sua caixa estava ali.

O excerto acima, de um episódio de brincadeira com caixas grandes nas quais as crianças podiam entrar, exibe o uso da frase "não, obrigado", por A, num contexto inadequado, uma vez que, primeiro, Li não estava oferecendo uma caixa para A, mas sim pedindo para ela ir para outra caixa (então, A não precisava dizer agradecer) e, segundo, A falou "não", porém não se recusou a pegar outra caixa, como evidencia sua ação. A, com certeza, conhecia o significado da palavra não, já o da palavra "obrigado", talvez estivesse aprendendo. De fato, nas verbalizações analisadas no item 5.4, agradecer apareceu uma única vez (nos focais finais e, coincidência ou não, foi Li quem falou, mas para C). É possível que A tenha apenas repetido uma frase que ouviu alguém dizer, sem saber exatamente o que significava. "Agradecer" faz parte do aprendizado de regras culturalmente transmitidas, as quais as crianças de até 3 anos estão apenas começando a aprender. 
O item 5.4, sobre comunicação verbal, e o item 5.3, sobre comunicação não verbal, apresentaram, respectivamente, um aumento na frequiência de episódios de verbalizações, e uma diminuição na frequiência de comportamentos não-verbais indicativos de comunicação, de um período inicial de focais para um intermediário e para um final. A partir destes resultados, poder-se-ia concluir que, ao longo do desenvolvimento de 1 a 3 anos de idade, as crianças estavam substituindo a comunicação não-verbal pela verbal, como afirmam, por exemplo, Papalia, Olds e Feldman (2006). Contudo, parece mais razoável supor que a comunicação não-verbal se modifica, sem nunca desaparecer, e cumpre funções diferentes daquelas da comunicação verbal. Argyle (1975) atribui ao comportamento não-verbal humano as funções de manejar a situação social imediata e de sustentar a comunicação verbal. Pode ser que os adultos atentem menos para os sinais não-verbais do que as crianças, mas eles tanto continuam presentes, que Birdwhistell (citado por Davis, 1979) estimou que $65 \%$ da comunicação humana é realizada de modo não-verbal.

A linguagem, obviamente, porém, possui um potencial representacional e simbólico muito forte, sendo um meio extremamente eficiente de transmissão cultural. Entre as crianças observadas, ficou bem evidente o papel do verbal para negociar brincadeiras, como ilustra o episódio a seguir:

\section{Focais finais (sala do Lilás, 16/11/04) - “mamãe, filhinha e papai”:}

$G i$ (f, 37 meses) aproxima-se de $B$ (f, 35 meses), que está passando roupa na mesa, e diz "Bianca, deixa eu passá junto com você??" e B responde "não. Eu sou a mamãe, você é o papai, tá?", Então, Gi fala "eu não sou o papai, eu sou menina". B diz "tá bom". Gi anuncia "eu sou a filhinha". Gi fica perto e B continua passando roupa. Gi fala e toca no tecido que B passa "tem que dobrá aqui, tem que dobrá aqui". $S$ ( $m$, 32 meses) chega e fala "oi, oi filhinha" para Gi, que responde "oi. Eu tô ajudando a mamãe". S fala "eu vou vuar" e Gi sai falando para $S$ "ah, eu vou na Bahia. O avião é ali ó", indicando uma cadeira amarela e caminhando até ela. Senta-se na cadeira e S chama-a "filhinha! Espera aí! Eu vou vuar" e Gi olha para $S$. 
O episódio apresentado demonstra de maneira muito clara a negociação de papéis e de assuntos de brincadeira. B não concordou em deixar Gi passar roupa junto com ela, no entanto, aceitou brincar com Gi, atribuindo-se papel de mãe e propondo a Gi dela ser o pai. Mas Gi discordou, porque sabia que era menina e que, portanto, deveria fazer um papel mais adequado ao seu gênero. Disse que seria a filha e B concordou. Depois, S, que provavelmente estava prestando atenção na interação das duas, entrou na brincadeira de modo coerente, cumprimentando Gi como se ela fosse a filha. De repente, após Gi explicar que estava ajudando a mãe, $\mathrm{S}$ propôs uma outra brincadeira e os dois compartilharam um novo significado (o de voar num avião).

Quanto ao papel da linguagem como facilitadora da transmissão de conhecimentos, serão analisados a seguir alguns episódios bastante esclarecedores. Durante as sessões de duplas, foi observada a criação de uma nova brincadeira por Gisele e a tentativa de Heitor ensinar esta brincadeira que aprendeu com ela para outras crianças. Embora Gisele fosse bastante "falante", Heitor apresentava um atraso no desenvolvimento da fala, o que dificultou, naquela situação em especial, que ele compartilhasse com outras crianças a brincadeira aprendida com Gisele:

\section{Duplas (1ª fase, 10/3/04) - Gi-H - "virando garrafinhas sobre a bola":}

Gi (f, 28 meses) pega duas garrafinhas tipo PET e dá uma para $H$ (m, 27 meses), que volta a brincar com o telefone (disca e segura). Gi pega uma bola e joga-a, depois segura a garrafinha e tenta abrí-la. Gi pega a bola e joga-a de novo e $H$ olha e ri. Gi continua segurando a garrafinha; chacoalha-a com a tampa para o chão (como se colocasse sal). Depois, ela pega a bola e chacoalha a garrafinha do mesmo jeito, sobre ela. Aí, segura a bola com o braço levantado, olhando para $H$, que olha para ela. Gi põe a garrafinha sobre a mesa; pega-a. Vira-a sobre a bola falando "um poco de aia". Vai até a outra garrafinha (que estava perto de $H$ ), segurando a primeira (que deixa sobre a mesa), pega-a, como se demonstrasse para $H$ (ao lado dela), e vira-a sobre a bola, falando de novo "um poco de aia", deixa-a e pega a outra, faz o mesmo movimento e fala "um poco de ete". Deixa as duas garrafinhas uma ao lado da outra e joga a bola. H ri. Ela vai buscar a bola, batendo uma palma na outra. Gi repete a ação e a fala mais oito vezes. Ela e H se olham e riem. H observa sua ação, mas também se distrai com a lanterna e Gi chama-o para que ele preste atenção. Depois, ela joga duas bolas em direção a $\mathrm{H}$ e ele pega uma do chão e imita a ação de Gi 
(embora de modo mais desajeitado; ele não coordena bem virar as garrafinhas sobre a bola), e joga a bola. Gi o vê e se aproxima dele e das garrafinhas. Os dois continuam a brincar assim, às vezes de frente um para o outro, como se estivessem espelhado suas ações, durante aproximadamente 2 minutos.

O episódio recém descrito apresenta o desenvolvimento da brincadeira que Gi criou e que H aprendeu. Gi sempre acompanhava suas "demonstrações” para H com verbalizações: "um poco de aia, um poco de ete", mas H imitava a ação sem pronunciar nenhuma palavra.

\section{Duplas ( $1^{\mathrm{a}}$ fase, $\left.10 / 3 / 04\right)$ - H- S - "tentando ensinar como virar garrafinhas sobre a}

\section{bola":}

$H$ (m, 27 meses) dá para $S$ (m, 23 meses) uma garrafinha, vocalizando. S está com uma bola e $H$ também. $S$ deixa a bola cair no chão e H pega-a Parece que H está tentando brincar com $S$ da brincadeira que aprendeu com Gi, mas, como ele não fala (e não demonstra), não consegue se fazer entender...

(Mais tarde, na mesma sessão)... H pega uma garrafinha e vira-a sobre a bola, depois pega a outra garrafinha e vira-a sobre a mesma bola (como aprendeu com Gi), ao lado de S. Tenta dar a outra bola para $S$ (acotovela-o segurando a bola e vocaliza), mas este não aceita ou não entende e continua a iluminar os objetos que estão sobre a mesa. Depois, S pega a bola que $H$ oferece, porém, ilumina-a com a lanterna. H tenta tirar a lanterna de $S$, aponta para a bola, depois para a lanterna. S levanta-se; H posiciona o corpo como se fosse jogar a bola, olhando para $S$. $S$ bate no assento da outra cadeira (oferecendo para $H$ se sentar lá), pega a outra lanterna e a oferece para $H$. H rejeita-a (parece dizer "não"), pega a outra bola e a oferece para $S$, diz "ete", mas $S$ não aceita e afasta-se. H sai andando atrás de $S$ até o outro lado da mesa, onde se senta na cadeira que $S$ estava sentado no início do episódio. H segura as duas bolas, levanta-se, vocaliza para $S$ estendendo uma das bolas. S parece não entender que H quer lhe dar uma bola e sim que ele está apontando para uma das lanternas que está com ele; então, ele lhe oferece a lanterna de novo, estendendo o braço, mas $H$ não aceita $e$ estende uma bola para $S$, que continua com as duas lanternas. H observa-o; tenta dar uma bola para $S$, estendendo-a na direção dele. $S$ se afasta com a lanterna e $H$ o segue. S aceita a bola oferecida por $H$ e ilumina-a com a lanterna. H busca uma garrafinha e a oferece-a para $S$, que deixa a bola sobre a mesa e pega a garrafinha. H olha para a bola deixada por $S$. $S$ chacoalha a garrafinha e a coloca sobre a mesa. H vocaliza (parece que quer dizer "não"), $S$ afasta-se da mesa com a lanterna. H pega a garrafinha e vai atrás de $S$; oferece-lhe a bola. $S$ pega-a e joga-a no chão. H lhe dá a garrafinha; S segura-a e ilumina a parede com a lanterna. H pega a bola e se aproxima de $S$ de novo. Encosta a bola na tampa da garrafinha e $S$ a dá para $H$. H tenta mostrar para $S$ a ação de virar a garrafinha sobre a bola, mas $S$ se afasta e continua a brincar com a lanterna. Então, $H$ aproxima-se da mesa, coloca a garrafinha lá, pega a outra, vira-a sobre a bola, deixa a garrafinha ao lado da primeira e joga a bola. Aponta para a bola e olha para $S$, como se estivesse querendo mostrar o resultado de sua ação. Porém, S estava de costas para ele. H procura a outra bola sobre a mesa, pega-a, aproxima-se das garrafinhas, vira uma e depois a outra sobre a bola e joga-a. Parece que desiste de ensinar para $S$ a brincadeira e fica brincando assim, sozinho. 
Este episódio mostra $\mathrm{H}$ tentando ensinar para $\mathrm{S}$ a brincadeira que aprendeu com Gi. Porém, o fato dele não falar parece que dificultou o entendimento de sua intenção, por S. Além disso, pode ser que a brincadeira tenha se tornado menos interessante e chamasse menos a atenção de $\mathrm{S}$, porque $\mathrm{H}$ não pronunciava nenhuma palavra ao virar as garrafinhas sobre a bola.

\section{Duplas (1ª fase, 11/3/04) - C-H - “ensinando como virar garrafinhas sobre a bola":}

$C$ ( $m, 20$ meses) pega a bola, fala algo, joga a bola para cima, vocal, joga-a de novo e deixaa. $H$ (m, 27 meses) pega outra bola e vira uma das garrafinhas sobre ela (como aprendeu com Gi), depois põe a garrafinha ao lado da outra - $C$ observa atentamente. $C$ pega a garrafinha e chacoalha-a. H pega a outra garrafinha e vira-a sobre a bola, demoradamente $e$ olhando para $C$, que não estava mais o observando e, sim, girando vendo uma garrafinha sobre a mesa (segurando-a, em pé, pela tampa). H, então, põe a garrafinha sobre a mesa e arremessa a bola para frente. $C$ corre para tentar pegar a bola que caiu no chão; chuta-a, vocalizando. H pega-a, vocaliza e corre para a mesa, onde pega a garrafinha e vira-a sobre a bola. Porém, C tenta pegar a bola de $H$, os dois disputam-na e C consegue ficar com ela. $C$ joga a bola para o alto e $H$ observa (ainda segurando a garrafinha). C continua jogando a bola, chutando-a e arremessando-a. H observa um pouco, depois coloca a garrafinha sobre a mesa, encosta a cadeira nesta e pega a lanterna...

(Mais tarde, na mesma sessão)... H pega uma bola e bate a outra mão nela; C pega a outra bola e imita H; os dois se olham. H pega uma garrafinha e vira-a sobre a bola, coloca a garrafinha sobre a mesa e pega a outra e vira-a sobre a bola. $C$ observa e tenta alcançar a garrafinha; $H$ dá a garrafinha para ele e $C$ vira a bola sobre a garrafinha, encostando-a em sua tampa. $H$ arremessa a bola. $C$ deixa a garrafinha sobre a mesa e ameaça jogar a bola, mas corre até a bola de $H$ e chuta-a. Depois, $C$ arremessa a bola na parede. $H$ volta para a mesa e repete a ação das garrafinhas sobre a bola. C continua arremessando a bola nas paredes. H joga sua bola; pega-a, volta para a mesa e encosta a bola na tampa de uma e depois da outra garrafinha (parecido com o jeito que $C$ fez); $C$ observa-o e volta a jogar bola. H arremessa sua bola. Os ficam jogando as bolas em direção às paredes e vocalizando.

Neste episódio, cuja sessão ocorreu no dia seguinte aos dos anteriores, H conseguiu, enfim, ensinar para outra criança a brincadeira que aprendeu com Gi. Porém, C imita apenas uma vez o gesto de $\mathrm{H}$ e de um modo um pouco diferente. Depois, $\mathrm{C}$ prefere ficar brincando com a bola. 


\section{Duplas ( $1^{\mathrm{a}}$ fase, 18/3/04) - A-C - "e a brincadeira das garrafinhas sobre a bola continua":}

$C$ ( $m, 21$ meses) pega uma garrafinha, mexe nela quase a chacoalhando, depois pega a bola e vira a garrafinha sobre a bola, reproduzindo o gesto que observou $H$ executando. Coloca a garrafinha sobre a mesa e faz movimento como se fechasse a tampa dela (acréscimo, "modificação", em relação ao gesto inicial de Gi); põe a bola no chão, dá passos em direção a ela como se fosse chutá-la, mas recolhe-a do chão e deixa-a sobre a mesa.

A descrição acima, embora curta, evidencia vários aspectos interessantes. O primeiro é que, apesar de $\mathrm{C}$ ter imitado $\mathrm{H}$ somente uma vez (e uma semana antes) e tenha feito, na ocasião, um movimento um pouco distinto daquele de $\mathrm{H}$ (virou a bola sobre a tampa da garrafa e não a garrafa sobre a bola), ele reproduziu exatamente o gesto de $\mathrm{H}$, ou seja, o gesto original criado por Gi. O segundo é que $\mathrm{C}$ fez três modificações em relação ao gesto inicial: ele virou uma garrafinha sobre a bola (e não as duas) e, depois disto, fez um movimento como se estivesse fechando a tampa da garrafa; além disso, ele pôs a bola no chão para chutá-la (em vez de arremessá-la). Outro ponto importante é que a brincadeira inventada por Gi tinha um componente verbal que, como H não conseguiu reproduzir, não foi aprendido por C. Pode-se observar, também, que C não se importou se A estava prestando atenção nele naquele momento, ou seja, parece que não havia a preocupação de ensinar a brincadeira para A.

\section{2.- Interação social}

A interação social entre as crianças observadas foi investigada, "especificamente" pois a comunicação faz parte da interação social -, quanto à existência de relações preferenciais no grupo, à persistência destas relações ao longo do tempo e às influências da afinidade social sobre a orientação da atenção, a imitação e os tipos de brincadeiras estabelecidas. 
A preferência ou afinidade social entre as crianças foi acessada a partir: da análise dos scans realizados no início e no fim de cada sessão de atividade lúdica livre; do julgamento das educadoras que cuidavam das crianças; da análise das sessões conjuntas (situação semicontrolada); e da verificação de parcerias preferenciais durante as brincadeiras (focais iniciais, intermediários e finais). Comparando-se os resultados obtidos nos scans com o julgamento das educadoras (item 4.2.2) constatou-se que houve, em geral, mais concordância (16) do que discordâncias (9) entre os dois métodos. Porém, vale afirmar que os dois se complementam e não deveriam ser utilizados isoladamente, pois os scans baseiam-se principalmente na proximidade física entre as crianças (medida uma vez por semana), enquanto o julgamento das educadoras parte de suas experiências diárias junto a elas. Por outro lado, a análise das sessões conjuntas (item 5.5) mostrou corresponder a uma amostra muito pequena para que pudesse trazer conclusões fidedignas acerca da preferência social entre as crianças. Já o exame das parcerias preferenciais durante a brincadeira (item 5.7) deve ser valorizado, não somente porque resultou em parcerias semelhantes às encontradas a partir dos scans e julgamento das educadoras, mas também porque considera as relações sociais que estavam realmente ocorrendo entre as crianças, ou seja, com quem elas estavam escolhendo para brincar, e sustenta-se numa grande quantidade de dados observacionais.

No decorrer do presente trabalho, constatou-se que a afinidade social exerce influências sobre a orientação da atenção, a imitação e os tipos de brincadeiras categorizadas de acordo com Morais e Otta (2003), Gosso e Otta (2003) e Parker (1984). Nas duplas com maior afinidade social houve maior freqüência de episódios de atenção conjunta e de atenção para objetos ou aspectos iguais ou semelhantes, e nas duplas com menor afinidade social houve uma tendência a mais episódios de atenção para objetos ou aspectos diferentes (item 5.2). Isto indica que entre crianças que apresentam maior afinidade social há mais sintonia e compartilhamento de atividades e significados. Como afirmam Carvalho e Rubiano (2004), a 
“atenção dirigida pela criança à atividade de um parceiro freqüentemente desencadeia a construção de brincadeiras conjuntas" (pp. 181). O ser humano, desde que nasce, manifesta uma sensibilidade muito grande ao estado de disponibilidade de seus cuidadores, como demonstram experimentos conduzidos por Murray (1980 apud Bussab, 2003): a interrupção artificial na relação que estava em andamento entre mães e bebês de 6 a 12 semanas de idade, levava-os a comportamentos sugestivos de perturbação, diferentemente do que acontecia quando a interrupção era natural. Trevarthen (1979 apud Fiamenghi, 1999) definiu o termo “intersubjetividade primária” para se referir às experiências imediatas de compartilhar estados subjetivos e Trevarthen e Hubley (1978 apud Fiamenghi, 1999) conceituaram o termo "intersubjetividade secundária" como sendo a busca para compartilhar experiências sobre os eventos e as coisas. A intersubjetividade secundária pode ser relacionada à capacidade de atenção conjunta. Tomasello et al. (2005) propõem que o engajamento social humano se desenvolve em três etapas: 1) Bebês de aproximadamente 3 meses de idade entendem que as outras pessoas são agentes vivos e, então, compartilham emoções e se relacionam diadicamente com elas; 2) Bebês de mais ou menos 9 meses de idade entendem que as outras pessoas agem orientadas por objetivos e, assim, compartilham objetivos e percepções e relacionam-se com elas de maneira triádica; 3) Crianças com cerca de 14 meses de idade entendem que as outras pessoas são agentes intencionais e, conseqüentemente, passam a compartilhar com elas intenções e atenção e se relacionar de modo colaborativo (criando representações cognitivas dialógicas, via internalização). A compreensão dos outros como agentes intencionais possibilita a aprendizagem por imitação e, portanto, a transmissão cultural (Tomasello, 2003).

Com base nos autores supracitados pode-se entender porque as duplas de crianças com maior afinidade social se envolveram em mais episódios de imitação (item 5.2) e em brincadeiras de contingência social (item 5.5) porque, provavelmente, compartilharam mais: 
experiências imediatas (intersubjetividade primária) e sobre eventos externos (intersubjetividade secundária), bem como, intenções - à maneira dos bebês com seus cuidadores, uma vez que estes desenvolvimentos decorrem, principalmente, das relações que estabelecem com pessoas mais próximas afetivamente. Já nas duplas de crianças com menor afinidade social, o clima sócio-afetivo é menos propício para o compartilhamento de experiências e intenções.

Quanto à análise da persistência de relações preferenciais no grupo, o item 5.5 mostra que, no último semestre de observações (scans e sessões conjuntas), houve persistência das relações entre Carlos e Laura, Carlos e Sílvio, Gisele e Heitor, e Heitor e Laura. O item 5.7 traz a persistência de relações em termos de parceiros preferenciais de brincadeira e a partir de observações feitas durante o primeiro, segundo e terceiro semestres (focais iniciais, intermediários e finais), o que evidenciou as parcerias entre: Carlos e Gisele, Carlos e Laura, Gisele e Laura, Gisele e Heitor, Gisele e Sílvio, e Heitor e Sílvio. Ao investigar a "persistência de relações preferenciais", pretendeu-se obter dados sobre a cultura do grupo estudado, pois a recorrência de relações entre sujeitos é um de seus aspectos. Mas esse tema também está ligado a outros dois muito importantes: amizade e vínculo. Bussab (2003), tendo como referência a Teoria do Apego desenvolvida por John Bowlby, afirma que "a vinculação afetiva decorre de interações afetuosas e de trocas lúdicas contingentes, e não da satisfação de outras necessidades primárias" (pp.29). Carvalho e Rubiano (2004) detectaram três dimensões características da amizade: convivência; afinidade; e cumplicidade. A convivência se relaciona ao compartilhamento de atividades ao longo do tempo e já está presente na primeira infância. A afinidade se relaciona à identificação de gostos, interesses e até competências, e pode explicar a interferência dos fatores "gênero" e "diferença de idade" na amizade que se estabelece entre as crianças (tendência delas brincarem mais com crianças do mesmo sexo e com idade próxima). A afinidade assim definida exerce influência na amizade depois da 
primeira infância. E, por último, a cumplicidade, que aparece mais no final da infância e está relacionada com atitudes de apoio, ajuda, consolo e cooperação. Portanto, de acordo com as autoras e as observações realizadas, no grupo estudado as parcerias preferenciais deveram-se, fundamentalmente, à convivência, o que representa a característica inicial do processo de amizade. Contudo, foram registrados episódios de cuidado entre as crianças e de defesa de um colega que estava sendo agredido, como mostram as descrições abaixo:

\section{Focais finais (sala do Lilás, 8/9/04) - "brincando com o bebê":}

$B(f, 33$ meses $)$ e La (f, 33 meses) beijam, acariciam e brincam com $T$ ( $m, \pm 12$ meses $)$, como os adultos brincam com os bebês.

(Mais tarde, no mesmo focal...) La faz cócegas e acaricia $T$, depois passa creme na barriga e nas costas dele.

T era um menino de aproximadamente 1 ano de idade, que estava fazendo "adaptação" no grupo estudado (transição do berçário para o grupo, onde ficava alguns períodos). B e La, meninas, quase dois anos mais velhas do que $\mathrm{T}$, relacionaram-se com ele como os adultos costumam se relacionar com os bebês, apresentando comportamentos "aloparentais" de cuidado, carinho e de fazer cócegas.

\section{Focais iniciais (brinquedoteca, 11/9/03) - "A defendendo S":}

\section{Focal de A:}

$A$ (f, 19 meses) vê $S$ (m, 18 meses) ser agredido ou incomodado por $C$ ( $m, 14$ meses) pela janela da casinha, entra na casinha, passa a mão na cabeça de $S$ carinhosamente, aproximase de C e puxa seu cabelo e sua blusa. Fala "Carlos feio, Carlos bobão". C não reage, o que não costuma fazer, pois é forte. (Talvez tenha ficado sem ação pelo inesperado da situação!!!). 
Neste trecho, A acolhe S, que foi agredido, e o defende agredindo C. É interessante notar que $\mathrm{C}$ era o mais novo e que $\mathrm{A}$, uma menina, defendeu $\mathrm{S}$, um menino. Além de agredir fisicamente $\mathrm{C}$, A também o agride verbalmente.

\section{Focal de C (seguinte ao de A):}

$C$ entra na casinha com um sapatinho de boneca na mão e coloca-o dentro do armário de plástico. Tenta fechar a porta, mas ela não fecha completamente (tem um pano no meio). Abre a porta de novo e pega o sapatinho. Vai em direção à máquina de lavar roupas, onde está (ainda) A; ele sobe com o tronco na máquina e ela diz "não" e bate na cara dele. Ele chora e desce. Cai sentado no chão, observa $S$, que entra na casinha, levanta-se e A puxa seu colete. Sai da casinha segurando o sapatinho e chorando em direção à educadora, que conversa com ele. $C$ dá meia volta e A vai atrás dele e puxa de leve seu colete de novo. A educadora fala "dodói, né Lili, dodói no Carlos". Ele vira-se para A e depois se afasta; ela se aproxima dele, segura seu colete pela frente e encosta em seu cabelo (não sei se foi um carinho ou um puxão fraco). As educadoras observam, assim como $S$, que estava perto e fala alto "não, nããăho", olhando para a cena. S estava empurrando dois bichos de plástico no chão e, então, direciona-os entre $C$ e A (talvez para separá-los), gritando "não" e "o Carlos, o Carlos!". A passa a mão no pescoço de C, parece acariciá-lo. Até que C agacha-se e pega um dos bichos de S; ele bate os pés no chão e grita várias vezes, quase chorando, "o Carlos". Então, A sai de novo em defesa de $S$ e puxa o colete de $C$, tentando afastá-lo dos bichos de $S$. $S$ bate na cara de $C$; este chora e bate em $S$, que também chora. A educadora intervém e separa-os.

Este episódio envolveu novamente A, C e S. No começo, A estava agredindo C, o que parece ter incomodado S. Ele tentou intervir colocando-se fisicamente entre A e C, falando "não" e o nome de C. Porém, depois C agrediu S, e A defendeu-o. No final, S e C acabaram brigando e a educadora teve que separá-los.

\section{3.- Tipos de brincadeiras}

Os tipos de brincadeiras apresentadas pelas crianças foram tratadas nos itens 5.5, 5.6, 5.7 e 5.9. No item 5.5 foi examinado o aspecto da persistência de significados construídos e compartilhados entre as crianças durante as brincadeiras observadas no último semestre de 
coleta de dados (focais, díades e sessões conjuntas). Constatou-se a recorrência dos seguintes enredos lúdicos: brincadeira de médico; brincadeira com arma (atirar, lutar, bater); ações ligadas à alimentação (comer, beber); brincadeira de fazer compras; contação de estórias; encaixe e desencaixe de peças; brincadeira de polícia; brincadeira de mamãe e filhinha(o). Foram analisados qualitativamente alguns episódios de brincadeira de médico.

No item 5.6, as brincadeiras foram categorizadas de acordo com Morais e Otta (2003), Gosso e Otta (2003) e Parker (1984). Verificou-se o efeito do grau de preferência social e da distância de idades entre as crianças sobre as brincadeiras das díades (último semestre). As conclusões foram que: duplas com maior afinidade social brincaram mais de brincadeiras de contingência social (por exemplo, C e S brincaram de esconde-esconde, escondendo-se dentro de caixas); brincadeiras simbólicas (faz-de-conta) foram mais freqüentes nas duplas com menor diferença de idade (o a 5 meses) e em que as crianças estavam com quase 3 anos, do que nas duplas com maior diferença de idade (12 a 17 meses); duplas formadas apenas por meninas brincaram mais de faz-de-conta, duplas formadas somente por meninos brincaram mais de brincadeiras paralelas e duplas mistas brincaram mais de brincadeiras do tipo "física". Morais e Otta (2003) também encontraram mais brincadeiras simbólicas em grupos exclusivamente femininos, embora com idade média de 5 anos.

No item 5.7 as brincadeiras foram classificadas em "solitárias", "solitárias com interação" e "acompanhadas". A análise dos focais iniciais, intermediários e finais mostrou que, em geral, as meninas brincaram mais com outras crianças do que sozinhas, diferentemente dos meninos. Além disso, constatou-se que, ao longo do tempo, a freqüência de ausência de verbalizações das crianças tendeu a diminuir em brincadeiras solitárias com interação, enquanto a freqüência de verbalizações tendeu a aumentar em brincadeiras acompanhadas. Isto confirma o caráter intrinsecamente social da comunicação. 
Finalmente, no item 5.9, as brincadeiras do último semestre (focais) foram classificadas quanto à ação usual ou não que as crianças faziam sobre os objetos e à ação sem objeto. Verificou-se que as crianças apresentaram significativamente mais ações usuais com objeto do que não-usuais ou sem objeto, porém, mais uma vez, houve diferenças de gênero: os meninos brincaram mais de modo não-usual com os objetos do que as meninas.

As diferentes formas de considerar as brincadeiras apresentadas pelas crianças permitiram a obtenção de uma caracterização ampla de como as crianças brincaram, constatando-se algumas divergências entre os sujeitos quanto ao gênero, à diferença de idade e ao tempo de convivência. Pode-se ilustrar a diversidade de brincadeiras observadas, com a descrição dos episódios adiante:

\section{Focais iniciais (brinquedoteca, 11/9/03):}

\section{Focal de La - "jogando objetos de um lado para o outro":}

La (f, 21 meses) está fora da casinha e perto de uma de suas janelas. Ela sobe sobre uma das almofadas de joelho, depois põe os pés nas duas almofadas e pendura-se na janela. Fica frente a frente com $H$ ( $m$, 22 meses), que está dentro da casinha (perto da pia). Pega alguns objetos da pia e H observa-a. Pega um pão de plástico que havia caído no chão (do seu lado) e coloca-o na boca, finge que come e fala algo ("pão"?), olhando para $\mathrm{H}$, que olha para ela. Depois deixa o pão sobre a pia e fala "se qué pão; dá?" (acho); H pega o pão e joga-o para o lado da janela onde La está. La olha para o pão, depois para $H$ e parece que faz alguma expressão engraçada, porque $H$ sorri aberto e joga outro objeto pela janela, sorrindo; depois mais outro, rindo e La vai buscá-lo. H fica com o braço dobrado e apoiado no parapeito da janela, segurando a cabeça com a mão (esperando La). La volta com um objeto na mão e joga-o pela janela para o lado de $\mathrm{H}$. Depois pega o pão e joga; $\mathrm{H}$ ri, os dois se olhando. Eles procuram outros objetos sobre a pia para jogarem. H pega um objeto e joga pela janela (sorri aberto), La pega um obj do chão (fora da casinha) e joga pela janela. Depois, procuram outros objetos e continuam a brincadeira.

Esta brincadeira pode ser classificada, de acordo com as categorias propostas, em: acompanhada, mista (menino e menina), contingência social, associativa e ação não-usual com objeto. Destaca-se a alternância de papéis entre $\mathrm{H}$ e La, que ora jogam objetos pela janela, ora vão buscar os objetos jogados pelo parceiro. 


\section{Focal de S - "esconde-esconde":}

$S$ (m, 18 meses) entra na casinha, segurando uma colher. La (f, 21 meses) fala "achou!", da outra casinha, e $S$ (e C que também estava dentro da casinha) vira-se imediatamente para olhar. $S$ e C (m, 14 meses) correm para a janela, onde está La, escondendo-se deles. S põe o braço para baixo do outro lado da janela e La aparece e vocaliza "ah", olha para $C$ e ri. Depois se esconde, agachando-se de novo; $C$ sai da casinha e $S$ continua esperando La aparecer. Ela aparece, olha para ele e vocal "ah"; S movimenta o braço para baixo como se fosse para bater em La de brincadeira (como fez antes) e ela desvia do golpe. La agacha-se e esconde-se, $S$ apóia-se na janela, olha para baixo onde está La e vocaliza algo como "Lhôhu". La aparece, vocaliza "ah" e olha para $C$, que estava reentrando na casinha (onde $S$ estava); S ri e tenta bater na cabeça de La. La se esconde e $S$ e C esperam-na no parapeito da janela. $S$ vocaliza "oóou"; La reaparece rápido, $S$ fala algo, ri, olha para $C$ e tenta bater na cabeça de La, que já havia se agachado. La reaparece rápido de novo, $C$ estende o braço e $S$ tenta bater na cabeça de La, que já havia descido. La reaparece e olha para $S$, que quase consegue bater em sua cabeça. A ( $f$, 19 meses) entra na casinha em que La está e fala "oiê", ficando de cara com C. C tenta encostar no rosto de A e ela se esconde ao lado de La, que já estava escondida. La reaparece olhando para $S$ (ela estava de frente para ele) e ri; então, $S$ se esconde e La olha para ele. Depois, La volta a se agachar e $S$ levanta-se. (Enquanto isso, A tenta brincar de esconder com $C$, mas primeiro ele se afasta da janela, depois ele põe a mão no rosto dela e puxa o seu cabelo. Ela se defende mordendo o braço dele, que sai da casinha chorando). S espera La aparecer e põe a mão na cara dela. Ela volta a se esconder. La reaparece, vê C saindo e faz cara de preocupada; $S$ encosta a mão na cara dela. Ela olha para $S$ e agacha-se, vocalizando "ah". A também se agacha. S fica na janela esperando. A ri; La reaparece vocalizando "ah" e olhando para $S$, que vira de costas para ela, rindo e com a mão na boca. Ele pára de brincar (acho que La, C e A continuam), fica com a mão na boca e parece pensativo.

Este episódio mostra um exemplo de brincadeira: acompanhada, mista, com regras (segundo Parker, 1984), associativa e sem uso de objeto. A brincadeira de esconde-esconde tem um caráter universal (Bruner e Sherwood, 1978), sendo encontrada em diferentes culturas. Porém, em geral é considerada como uma brincadeira envolvendo uma criança e um adulto, que a inicia. De fato, as primeiras brincadeiras deste tipo são aprendidas com os adultos, que brincam de esconder e achar com seus bebês. Mas a descrição acima evidencia que crianças de 21 meses já são capazes de começar uma brincadeira de esconde-esconde com coetâneos, sem a intervenção de um adulto. Gosso (2004) também observou brincadeiras de esconde-esconde exclusivamente entre crianças, embora mais velhas (com idades de 4 a 13 anos), numa aldeia Parakanã. Além disso, deve-se destacar a introdução, por $S$, de um 
componente de brincadeira turbulenta (tentar bater na cabeça de La), modificando um pouco a brincadeira original de esconde-esconde.

\section{Focais intermediários (brinquedoteca, 31/3/04) - "alimentando os bichos":}

Segurando um copinho, $C$ (m, 21 meses) pega um animal de plástico e coloca-o apoiado na janela da casinha. C chacoalha o copo segurando-o pela tampa, agacha-se, pega um garfo, levanta-se, coloca-o dentro do copo e depois na boca do animal (!). Põe o garfo no copo, fala ou canta para o animal, aproxima o copo da boca do animal (fala "tó"), abaixa-se e aproxima seu rosto do animal, olhando para ele. Encosta de novo o copo na boca do animal, põe o garfo dentro do copo como se estivesse tirando algo de dentro dele, sai da casinha, deixa o copo no chão e pega outro animal. Apóia-o na janela ao lado do outro. Gi ( $f, 29$ meses) entra na casinha e quando $C$ entra lá ela pergunta para ele quem pôs aquilo ali, se foi ele e se era o lobo mau; ele não responde, fica olhando para os animais.

O episódio acima exemplifica uma brincadeira do tipo: solitária $(\mathrm{C})$ com interação (Gi), simbólica e com ação não-usual com objeto. Observam-se os comportamentos de cuidado que $\mathrm{C}$ dedica aos animais, alimentando-os, cantando para eles e aproximando seu rosto dos animais, à maneira que os adultos fazem com crianças pequenas.

\section{Focais intermediários (brinquedoteca, 7/4/04) - "tomando banho":}

$S$ (m, 24 meses) pega um pião e coloca-o dentro de um copo. Vira o copo sobre uma banheira e o pião cai dentro dela. Pega-o e coloca-o no porta-sabonete da banheira, diz "vou tomar banho", faz gesto como se experimentasse a temperatura da água com as mãos e põe um pé dentro da banheira, depois o outro. Senta-se dentro dela, pega o pião e o copo, põe o pião dentro do copo, vira-o e o pião cai sobre suas pernas, pega o pião, o copo cai fora da banheira e $S$ sai dela segurando o pião, levanta-a procurando o copo, acha-o e coloca o pião dentro do copo. Vira o copo sobre a banheira e o pião cai dentro dela. Coloca o pião na saboneteira da banheira e o copo também; esbarra na banheira e eles caem dentro dela. Entra na banheira, senta-se, pega o copo, põe o pião dentro, levanta-se e sai da banheira.

Este episódio ilustra uma brincadeira solitária, simbólica, com ação não-usual com objeto. O faz-de-conta de S refere-se a uma atividade cotidiana das crianças de sua idade ou menores: tomar banho na banheira e brincar com o sabonete ou outros objetos durante o banho. 


\section{Focais finais (sala do Lilás, 29/10/04) - "bolo-construção":}

La (f, 35 meses) aproxima-se de $S$ (m, 30 meses), que estava empilhando e encaixando peças tipo Lego, e ajuda-o, pegando as peças do pote e do chão e dando-as para ele. Quando as peças acabam, olham para o que construíram e sorriem. S, então, começa a cantar parabéns, como se a construção fosse um bolo e La acompanha-o, os dois batendo palmas e sorrindo. La fala para S assoprar, ele assopra, depois ela e ele, até que La derruba a construção (como se fosse com a força de seu sopro). S não gosta e diz "não", levantando a construção. La o ajuda a remontá-la, mas falta uma peça em sua base e ela cai; La ri, S levanta-a. Os dois voltam a montá-la, mas quando a construção tomba de novo, La ri e S sorri. Quando conseguem remontá-la, La pega a embalagem, vira-a para baixo e bate em seu fundo (como um tambor); diz para $S$ colocar a construção sobre o fundo da embalagem, mas $S$ voltou a cantar parabéns, a bater palmas e a assoprar. La chama-o. S pára e depois volta a cantar. La tenta tirar uma peça da construção, mas $S$ não quer (isto se repete duas vezes). La fica olhando para outro lado e batendo a embalagem no chão. S tira uma peça da construção $e$ finge que a está comendo; olha em direção ao local para onde La está olhando. Depois recoloca a peça e tomba a construção; La olha e ri, S também. La pega umas peças que caíram e coloca-as umas sobre as outras sobre o fundo da embalagem. S remonta a construção sobre o chão; quando deixa cair uma peça, La pega-a e ri, olhando para $S$, que também olha para ela e sorri fechado. Os dois se olham às vezes. (Na continuação do focal, além dos 5 minutos, eles voltam a construir juntos).

A brincadeira "bolo-construção" pode ser classificada como: acompanhada, simbólica (mas também de construção), cooperativa e ação não-usual com o objeto. Deve-se ressaltar o compartilhamento do significado da construção como bolo, entre La e S: S começou a cantar parabéns e La o acompanhou, mas o que demonstra que ela compartilhou o significado da construção como bolo foi o fato dela ter dito para S assoprar (uma vela imaginária). Depois, parece que La achou mais divertido tombar a construção; como S não concordava com ela, ela direcionou sua atenção para longe dele. Então, S imitou o ato de La de derrubar a construção e conseguiu, assim, que La voltasse a brincar com ele.

\section{Duplas finais ( $5^{\mathrm{a}}$ fase, $\left.14 / 10 / 04\right)-\mathrm{Gi}-\mathrm{H}$ :}

\section{“Bambolê-espelho":}

$H$ (m, 35 meses) está batendo um bambolê no chão. Gi (f, 36 meses) pega o outro bambolê e diz "olha isso, mais bela que eu não existe", segurando o bambolê no ar como se fosse um espelho! 
$\mathrm{O}$ excerto apresentado mostra uma brincadeira paralela entre $\mathrm{H}$ e Gi. A brincadeira de H com o bambolê é solitária (de acordo com a classificação do item 5.7) e física, enquanto a de Gi é solitária e simbólica. As duas, embora de caráter diferente, demonstram ações nãousuais com objeto. A brincadeira de Gi indica a influência de um aspecto macro cultural: ela repete a fala da bruxa da história da Branca de Neve.

\section{"Lutando com bambolês":}

Gi diz que H era o lobo e ela o menino. Ela tenta pegar $H$ com o bambolê. H reage e coloca seu bambolê no pescoço de Gi (como ela tentou fazer com ele). Ela foge e ele corre atrás dela, tentando pegá-la, os dois rindo. Depois, brincam de lutar com o bambolê (Gi fala "meus poderes"). Gi volta a fugir de H e ele a correr atrás dela. (Ela se esconde atrás de mim).

Este trecho, observado durante a mesma sessão de duplas (Gi-H), exibe uma brincadeira acompanhada, mista, simbólica, associativa e com ação não-usual com objeto. O bambolê foi utilizado, primeiro para capturar o colega (tentando colocar o bambolê no pescoço dele) e posteriormente como uma arma de contato, talvez uma espada (as crianças batiam um bambolê no outro).

\section{4.- Imitação}

Episódios de imitação foram observados recorrentemente entre as crianças (como verificou Pedrosa, 1989, trabalhando com crianças de 1 a 3 anos de idade). Este fato possibilitou a investigação da imitação como recurso comunicativo e de transmissão cultural na primeira infância (itens 5.3, 5.5 e 5.9). No item 5.3, constatou-se que a freqüência de imitação entre as crianças foi significativamente maior do que a esperada nos focai finais, ou 
seja, quando a maioria das crianças estava com idade próxima a 36 meses e tinha um longo tempo de convivência no grupo. No item 5.9 obteve-se que, no mesmo período (focais finais e duplas finais), a freqüência de interação social após imitação foi maior do que a esperada. Além disso, a situação de duplas pareceu favorecer a ocorrência de interação social após imitação. Estes resultados confirmam as considerações de outros autores: Carvalho (1989) afirma que, para a criança que ainda não domina o código verbal, a imitação é um recurso comunicativo; Nadel (2002) concluiu, em um experimento com 150 crianças, que a imitação é utilizada como um modo de comunicação em crianças pré-verbais e que ela está mais presente nas trocas sociais entre as crianças a partir da idade de 18 meses, com um pico aos 30 meses; Nagy (2006) ensinou um gesto, feito com a extensão do dedo indicador, a 39 recém nascidos (nas primeiras 3 a 96 horas de vida) e verificou que eles não foram apenas capazes de imitar o gesto, como, depois, manifestá-lo sem estímulo prévio, na presença do experimentador, o que a autora interpretou como sendo uma iniciativa de comunicação. A brincadeira "boloconstrução", examinada no item 6.3, exemplifica o uso da imitação para recuperar a interação social entre duas crianças: $\mathrm{S}$ imita um ato que La havia executado e achado divertido (derrubar a construção) e consegue, deste modo, que La volte a brincar com ele.

No item 5.5, foram identificadas algumas brincadeiras que as crianças imitaram num episódio e depois a reproduziram num outro momento, com outras crianças (por exemplo, a brincadeira da "virando garrafinhas sobre a bola", que foi descrita no item 6.1). Resultados assim comprovam a função da brincadeira na transmissão de conhecimentos e, portanto, de cultura.

No item 5.9 comparou-se a imitação de ações usuais ou não com objeto e ações sem objeto registradas nos focais iniciais, intermediários e finais e nas duplas iniciais e finais. Concluiu-se que, nos focais iniciais e nos finais, as crianças imitaram significativamente mais ações sem objeto; nas duplas iniciais, houve uma freqüência significativamente maior de 
ações usuais com objeto e, nas duplas finais, de ações não-usuais com objeto. Estes resultados são semelhantes aos obtidos por Nadel (2002), que realizou um experimento com díades de crianças de 2 anos de idade e díades com crianças de 3 anos. As crianças foram submetidas a duas situações de teste: uma em que havia um conjunto de 20 objetos não repetidos e outra em que havia dois conjuntos de 10 objetos idênticos. A autora relatou que não houve efeito das situações diferente para as díades de 3 anos, mas houve para as de 2 anos, que imitaram seus parceiros somente na situação em que estavam disponíveis os pares de objetos. No presente trabalho, as sessões de duplas (situação semicontrolada) seriam equivalentes à situação dos dois conjuntos de 10 objetos de Nadel, enquanto as sessões de focais (atividade lúdica livre) seriam similares à situação dos 20 objetos diferentes. Na verdade, nos focais havia muito mais do que 20 objetos disponíveis para as crianças brincarem e, além disso, estavam presentes mais crianças (e não apenas duas, como nas duplas). Pode-se concluir, então, que as sessões de díades foram mais propícias, devido ao arranjo experimental, do que as sessões de focais, para a ocorrência de episódios de imitação de ações com objeto entre as crianças. Ao mesmo tempo, parece que as crianças com idade próxima aos 3 anos preferiram imitar ações nãousuais com objeto (díades finais), o que confere maior valor ao efeito da novidade nesta faixa etária.

Um exemplo de como dois objetos semelhantes podem suscitar a imitação de uma ação aparece no episódio seguinte:

\section{Focais finais (sala do Lilás, 9/11/04) - "escovando o cabelo frente a frente":}

$C$ ( $m, 28$ meses) pega escova e espelho de mão, mostra o espelho para $S$ ( $m, 31$ meses) e fala algo. S olha, porém brinca com peças quadradas tipo Lego. C escova o cabelo, voltado para $S$, depois oferece para ele diversas vezes a escova (ou para escová-lo?), até que $S$ responde e faz com a cabeça que não quer (sorri aberto). C vai até a educadora, deixa o espelho sobre a mesa, parece que olha para $S$, e $S$, que o observava, pega o espelho. C escova o cabelo da educadora e pega uma outra escova que estava sobre a mesa. S passa o espelho no próprio cabelo, como viu C fazer (IMITA-o), olhando para $C$, que parece que também olha para ele (de costas para câmera). C afasta-se da educadora. $S$ "penteia" o próprio cabelo com o 
espelho, aproximando-se de $C$, mas ele não viu, pois estava de costas em relação a $S$. $C$ virase, vê $S$, anda pela sala e $S$ vai atrás dele. $C$ escova o próprio cabelo, $S$ se coloca à sua frente, balançando o corpo com o espelho na mão. Então, $C$ dá uma de suas escovas para $S$, que larga o espelho. Os dois se colocam frente a frente, C escova o próprio cabelo, $S$ olha e IMITA-o. Os dois ficam assim, escovando o cabelo e olhando um para o outro por alguns instantes; depois $C$ pára e afasta-se, $S$ continua. $C$ vira-se de novo para $S$ e o vê escovando o cabelo; ele volta a escovar o cabelo e os dois ficam novamente frente a frente, porém mais distantes, escovando o cabelo. $C$ vê $S$ segurando com a outra mão o cabelo e coloca a outra mão no cabelo também (C IMITA $S$ ), mas faz movimentos como se estivesse lavando-o. $S$ tira a mão do cabelo e $C$ também; continuam a escová-lo. $C$ pára e movimenta os braços dobrados para o alto, para cima e para baixo (mais ou menos como se faz quando se comemora algo), depois volta a escovar o cabelo. Até aqui, exceto pelo início, a interação foi não-verbal. Agora, $S$ e C trocam algumas palavras (que não entendo) e os dois param de escovar o cabelo; vão para a mesma direção, mas se separam. Largam as escovas.

Nesta descrição, a interação entre as crianças se dá quase que inteiramente de modo não-verbal; as duas crianças parecem reproduzir um espelho, imitando as ações uma da outra, frente a frente. Deve-se destacar a semelhança de formato entre o espelho de mãe que estav com S e a escova que estava com C. Depois C deu uma escova para S. O oferecimento de um objeto parecido com aquele com o qual a criança está foi um fator que precedeu os episódios de imitação entre tríades e díades de crianças pequenas observadas por Nadel (2002).

\section{5.- Persistência de significados}

O compartilhamento e a persistência de significados foram assuntos freqüentemente abordados durante este trabalho. Vários episódios de brincadeira que foram destacados evidenciam a presença de persistência de significados construídos entre as crianças, por exemplo: "vocalizações no gira-gira", "bate-bate e silêncio", "mamãe, filhinha e papai", "virando garrafinhas sobre a bola" e "brincando de médico" (esta última, analisada no item 5.5). Todas estas brincadeiras têm em comum as características de ação conjunta e 
coordenada dos indivíduos e de permanência de um significado compartilhado que se difunde dentro do grupo (ou parte dele) - requisitos para considerar a existência de persistência de significados, segundo Carvalho, Império-Hamburger e Pedrosa (1996). A orientação da atenção, o primeiro princípio de sociabilidade, que precede o compartilhamento e a persistência de significados (Pedrosa e Carvalho, 1995; Carvalho, Império-Hamburger e Pedrosa, 1996 e 1998; Carvalho e Pedrosa, 2004 e Carvalho e Rubiano, 2004) foi abordada à parte, apenas nas duplas e com relação à maior ou menor afinidade social entre as crianças, porém, na realidade, é um fenômeno que ocorre em conjunto com os outros dois. Deve-se ressaltar o papel fundamental da imitação para que ocorra persistência de significados. Demonstrou-se que a imitação não somente foi utilizada como recurso comunicativo entre as crianças, como também de transmissão de comportamentos e conhecimentos na construção da microcultura do grupo estudado.

Uma brincadeira interessante a ser destacada foi aquela que se desenvolveu entre as crianças do grupo e duas outras, mais velhas, que vieram do grupo de crianças maiores para visitar as mais novas. Apesar da interação com crianças mais velhas (em torno de 5 anos de idade), as menores é que conduzem a brincadeira:

\section{Focais finais (sala do Lilás, 9/11/04) - “propagação de um gesto atípico": Focal de Gi:}

$B$ (f, 35 meses), La (f, 35 meses), $S$ (m, 30 meses) e Gi (f, 37 meses), sentados em frente e perto das crianças maiores, oferecem para o menino o que seguram nas mãos: La, um pote com lápis de cor; $B$, um bichinho de pelúcia; $S$, um carrinho de metal; e Gi, uma caixa de fita VHS. Primeiro, falam "qué estelesse?" (as duas crianças maiores se olham, repetem o que ouviram e riem), mas depois, La fala "qué pexe" (e as duas crianças maiores se olham e repetem de novo o que ouviram; riem, meio surpresas). S e B IMITAM La. Gi pergunta, estendendo a fita para o menino, "qué morango?" e La, B e S IMITAM-na. Então, La oferece "uva"; S e Gi IMITAM-na; La oferece chocolate, S, Gi e B IMITAM-na. Durante a interação, as crianças menores não olham somente para as maiores, mas também umas para as outras (e sorriem, riem). 


\section{Focal de B:}

B fica quieta um pouco e depois oferece de novo o bichinho para o menino, porém desta vez fala "qué ete (ou pexe)?", como La havia acabado de falar ("qué pexe?"). La, Gi e C (m, 28 meses) também perguntam para o menino se ele quer peixe. La faz isto com um gesto da mão (já que a educadora pegou o pote de lápis que ela segurava): com o dedão, e os dois dedos seguintes em posição de tesoura. $B$ vê e acho que tenta imitá-la, pois faz a pergunta seguinte acompanhada de um gesto com a mão, semelhante ao de La (e sem o bichinho): com o dedão e o dedo indicador, como um revólver ou um apontamento. La e B, principalmente, continuam fazendo ofertas para o menino (e B faz o gesto, em vez de oferecer o bichinho). A (f, 33 meses), $C, G u$ ( $m, 19$ meses) e Gi também estão no semicírculo e riem, às vezes. $\boldsymbol{A}$ oferece também e faz gesto com a mão, parecido com o de B e La. Depois, Gi faz o mesmo. No fim, o gesto de La (que também ofereceu com a mão aberta) fica mais parecido ou igual até ao de B (revólver ou apontar). La afasta-se andando de costas, perguntando e fazendo o gesto para o menino. B fica em pé no lugar onde La estava e continua perguntando e fazendo gesto. Durante toda a interação, o menino, em geral, batia de leve na mão das crianças.

\section{Focal de S:}

$S$ e $C$ fogem das crianças maiores (um menino e uma menina), que imitam bichos, andando de quatro atrás deles... Depois de um tempo fugindo de um lado para o outro da sala, $C$ e $S$ ficam num canto e o menino aproxima-se, de quatro; $C$ fala "qué peta (chupeta)?" e S IMITAo, ambos estendendo o braço para o menino. Foi B que começou com esta história de oferecer a chupeta, que ela estava usando, e as crianças maiores acharam graça disto. $S$ riu. A menina também se aproximou. $C$ pediu para $S$ pegar algo para ele, mas $S$ estava mais interessado em olhar para a menina, que estava de quatro à sua frente. B puxa o cabelo do menino e sai dando gritinhos; $S$ IMITA $B$, depois $C$ faz o mesmo. $O$ menino reage e as educadoras interferem. $S$ foge até a mesa e se esconde atrás da cadeira, $C$ faz o mesmo... Gi olha $S$ e $C$ escondidos. $C$ foge, $S$ vai atrás. Quando chega perto de $C$, ele está sendo pego pelo menino e foge; $S$ é pego pelo menino também, mas foge. Os dois ficam atrás da mesa, olhando para a menina e o menino que, depois de um tempo, começam a se aproximar deles. $C$, que já estava falando "sai daí bicho" para eles (porque a menina e o menino estavam no canto oposto da sala, longe deles) e estendendo o braço em sua direção, sai de trás da mesa e "enfrenta-os", repetindo as palavras e o gesto. S fala "sai daí, sai daí tampinha"; o gesto dele é igual ao que se iniciou durante o focal de B: dedão e indicador como arma ou apontamento. Já $C$ parece que estava com um carrinho na mão, pois, no fim do focal, pergunta para $S$ onde estava o carrinho dele (mas o gesto de C também é aquele do focal de B).

Os trechos dos focais apresentados acima exibem diferentes aspectos de uma brincadeira, entre as crianças do grupo e duas maiores, que começou no focal de Gi e se prolongou até o focal de S. No focal de Gi, as crianças começaram oferecendo objetos para o menino. No focal de B, quando a educadora tirou o objeto que La segurava, ela fez um gesto atípico de oferecimento que foi imitado por outras crianças e, em seguida, alterado por B. Esta 
alteração foi incorporada por outras crianças e persistiu até o focal de S. Pode-se afirmar que as crianças pequenas criaram um gesto novo, compartilharam seu significado e sustentaram sua persistência (durante, aproximadamente, 15 minutos). Este é um exemplo magnífico de microcultura no grupo de brinquedo.

Um outro ponto importante a ser destacado é a importação de aspectos macroculturais para a brincadeira, de sua assimilação e da construção de aspectos particulares da microcultura do grupo, como evidencia o episódio a seguir:

\section{Focais iniciais (praça, 16/10/03) - “o eco":}

$A(f, 20$ meses $)$ está dentro de um tubo grande de concreto, correndo de uma extremidade à outra e gritando "eco" cada vez que atinge uma das extremidades.

O tubo de concreto é, na verdade, um tubo de encanamento aberto dos dois lados que ganhou a função de uma espécie de caverna, na creche. As educadoras referiam-se a ele como "eco". Elas lhe atribuíram este nome em parte pela existência de um fraco eco dentro do tubo, mas também porque leram para as crianças uma poesia da Cecília Meireles (1990) que se chama "O Eco":

\section{$O E C O$}

$O$ menino pergunta ao eco

onde é que ele se esconde

Mas o eco só responde: "Onde? Onde?"

O menino também lhe pede:

"Eco, vem passear comigo!"

Mas não sabe se o eco é amigo

ou inimigo

Pois só lhe ouve dizer:

"Migo!" 
É difícil saber se, através desta poesia e da experiência que as crianças tinham dentro do tubo de concreto, elas sabiam realmente qual o significado de "eco". Mas o fato é que o tubo adquiriu o significado de lugar de brincar de eco. Ao mesmo tempo em que a poesia da Cecília Meireles faz parte da cultura brasileira das histórias infantis, ela foi um veículo, no contexto da creche, para atribuir um significado específico a um objeto que, originalmente, seria usado como tubo de encanamento de esgoto. Aqui há a questão tanto do transporte de um objeto de seu local funcional original para um contexto completamente diferente, quanto à da ação das educadoras e das crianças sobre o objeto. Ao atribuírem o nome "eco" ao tubo de concreto, as educadoras não apenas modificaram o significado do tubo, como também da palavra eco. É verdade que a ação verbal das educadoras relacionou o tubo com o eco, porém a ação das crianças no tubo legitimou o significado do tubo como lugar onde se faz e fala eco. 


\section{7- CONCLUSÕES}

Os diferentes tipos de análises realizadas possibilitaram que fossem alcançados os objetivos propostos:

1) As análises qualitativas evidenciaram os processos de construção de microcultura no grupo estudado. As crianças foram capazes de criar e compartilhar significados utilizando-se da comunicação não-verbal, porém a linguagem mostrou ser uma ferramenta facilitadora da transmissão de conhecimentos no grupo;

2) Observou-se a importação de aspectos macroculturais para a brincadeira (como, por exemplo, elementos presentes em contos de fada). Contudo, as crianças não se limitaram apenas a reproduzir aspectos da macrocultura, elas também a modificaram, criando diversas brincadeiras novas e que chamavam a atenção de outras crianças, que as imitavam (principalmente quando as crianças estavam com idades mais próximas aos 3 anos e com maior tempo de convivência);

3) A imitação provou ser um mecanismo eficiente para que ocorresse a persistência de significados construídos no grupo;

4) Verificou-se a existência de parcerias preferenciais entre as crianças e de comportamentos de cuidado (à semelhança daqueles apresentados pelos adultos em relação a crianças pequenas);

5) A preferência social foi um fator propiciador de comportamentos de atenção conjunta e de imitação;

6) De acordo com os resultados obtidos, os três princípios de sociabilidade formulados por parecem adequados para a explicação da emergência do modo verbal de comunicação, via atenção conjunta e imitação; 
7) Apesar de ter sido detectada uma redução na freqüência dos comportamentos não-verbais indicativos de comunicação, as crianças continuaram se comunicando deste modo, sendo mais provável que a comunicação não-verbal fique mais complexa, sutil e integrada à linguagem, à medida que as crianças aprendem a se comunicar verbalmente;

8) A linguagem facilitou a negociação de brincadeiras e de significados entre as crianças e tornou as brincadeiras simbólicas mais elaboradas.

O presente trabalho pode contribuir para uma melhor compreensão da $1^{\mathrm{a}}$ infância, principalmente quanto ao conhecimento sobre como se dá a comunicação e a interação social entre crianças de 1 a 3 anos de idade, somando-se a outros que pretendem uma visão da criança como um ser atuante e criativo. Para concluir, será citado um trecho de Cohn (2005):

Quando a cultura passa a ser entendida como um sistema simbólico, a idéia de que as crianças vão incorporando-a gradativamente ao aprender "coisas" pode ser revista. A questão deixa de ser apenas como e quando a cultura é transmitida em seus artefatos (sejam eles objetos, relatos ou crenças), mas como a criança formula um sentido ao mundo que a rodeia. Portanto, a diferença entre as crianças e os adultos não é quantitativa, mas qualitativa; a criança não sabe menos, sabe outra coisa. (Pp. 33). 


\section{8- REFERÊNCIAS BIBLIOGRÁFICAS}

ALBANESE, O \& ANTONIOTTI, C. 1998). O desenvolvimento da Linguagem. In A. Bondioli \& S. Montovani (Eds.), Manual de Educação Infantil: de 0 a 3 anos - uma abordagem reflexiva (pp. 202-211).Porto Alegre: ArtMed.

ALTMANN, J. (1974). Observational study of behaviour: Sampling methods. Behaviour, 49, 227-267.

ARGYLE, M. (1975). Non-verbal communication in Human Social Interaction. In R.A.Hinde (Ed.), Non-verbal Communication. .(pp. 243-269) Cambrigde: Cambridge University Press.

BERGAMASCO, N. H. P. \& BERALDO, K. E. A. (1990). Facial expressions of neonate infants in response to gustatory stimuli. Brazilian Journal of Medical and Biological Research, 23 (3-4), 245-249.

BLURTON-JONES, N. (1981). Características do estudo etológico do comportamento humano. In N. BlurtonJones (Org.) Estudos Etológicos do Comportamento Humano (pp. 3-36). São Paulo: Pioneira.

BOESCH, E. E. (1991). Symbolic Action Theory in Cultural Psychology. Berlin/New York: Springer-Verlag. Pp. 40-142.

BRANNIGAN, C. R. \& HUMPHRIES, D .A. (1981). Comportamento não-verbal humano, um meio de comunicação. In N. Blurton-Jones (Org.), Estudos Etológicos do Comportamento Humano (pp. 37-66). São Paulo: Pioneira.

BRUNER, J., S. \& SHERWOOD, V. (1978). Peekaboo and the Learning of Rule Structures. In J.R. Bruner, A. Jolly \& K. Sylva (eds), Play-Its Role in Development and Evolution. (pp.277-285).New York: Penguim Books.

BUSSAB, V. S. R. \& RIBEIRO, F. L. (1998). Biologicamente cultural. In L. Souza; M .F. Q. de Freitas \& M. M. P. Rodrigues (Orgs.), Psicologia - Reflexões (Im)pertinentes (pp. 175-193). São Paulo: Casa do Psicólogo.

BUSSAB, V. S. R. (2003). Afetividade e interação social em crianças: perspectiva Psico-Etológica. Tese de Livre-docência, Instituto de Psicologia, Universidade de São Paulo, São Paulo.

BUSSAB, V. S. R., PEDROSA, M .I.\& CARVALHO, A.. M. A (2007). Encontros com o outro: empatia e intersubjetividade no primeiro ano de vida Psicologia USP, 18 (2), 4-28.

CARVALHO, A. M. A. (1989).Brincar juntos natureza e função da interação entre crianças. In C.Ades (Org.), Etologia de animas e de homens (pp. 199-248). São Paulo: Edicon. 
CARVALHO, A. M. A. (1992). Seletividade e vínculo na interação entre crianças. Tese de Livre-docência, Instituto de Psicologia, Universidade de São Paulo, São Paulo.

CARVALHO, A. M. A. (1998). Etologia e comportamento social. In L. Souza; M. F. Q. de Freitas \& M. M. P. Rodrigues (Orgs.), Psicologia - Reflexões (Im)pertinentes (pp. 195-224). São Paulo: Casa do Psicólogo.

CARVALHO, A. M. A. \& BERALDO, K. E. A. (1989). Interação criança-criança: ressurgimento de uma área de pesquisa e suas perspectivas. Cadernos de Pesquisa, 71, 55-61.

CARVALHO, A. M. A. \& PEDROSA, M. I. (2002). Cultura no grupo de brinquedo. Estudos de Psicologia, 7 (1), 181-188.

CARVALHO, A. M. A.; PEDROSA, M. I. (2004). Communication in early infancy: Some reflections from an evolutionary perspective. In A. U. Branco; J. Valsiner (Orgs.), Communication and Metacommunication in Human Development.( pp. 83-105). Greenwich: CT.

CARVALHO, A. M. A. \& RUBIANO, M. R. B. (2004). Vínculo e compartilhamento na brincadeira de crianças. In M.C. Rossetti-Ferreira; K. E. Amorim; A. P. Silva \& A. M. A. Carvalho (Orgs.), Rede de Significações. (pp. 171-187)Porto Alegre: Artes Médicas.

CARVALHO, A. M. A., IMPÉRIO-HAMBURGER, A. \& PEDROSA, M. I. (1998). Interaction, regulation and correlation in the context of human development: Conceptual discussion and empirical examples. In M. Lyra \& J. Valsiner (Eds.), Child development within culturally structured environments: Vol. 4: Construction of psychological processes in interpersonal communication (pp. 155-180). Stamford, CT: Ablex Publishing Corporation.

CARVALHO, A.; IMPÉRIO-HAMBURGER, A. \& PEDROSA, M. I. (1996). Interação, regulação e correlação no contexto do desenvolvimento humano: discussão conceitual e exemplos empíricos. Publicações IFUSP, v. P-1196, 1-30.

CASALDERREY, L., M. (1992). La comunición entre los niños en la escuela infantil. Revista de la asociación de Mestres Rosa Sensat, 13, 10-13.

COHN, C. (2005). Antropologia da Criança. Rio de Janeiro: Jorge Zahar Editor.

CORSARO, W. (1985). Friendship and Peer Culture in the Early Years.Westport: Ablex Publishing.

CORSARO, W. (1997). The Sociology of Chidhood. Thousand Oaks, CA: Pine Forge Press.

DAVIS, F. (1979). A comunicação não-verbal. São Paulo: Summus.

DARWIN, C. (2000). A Expressão das Emoções no Homem e nos Animais. São Paulo: Companhia das Letras.

DAWKINS, R. (1976) The Selfish Gene. New York: Oxford University Press. 
DAWKINS, R. \& KREBS, J. R. (1978). Animal signals: Information or manipulation. In J.R. Krebs \& N.B. Davis (Eds.) Behavioural Ecology: An Evolutionary Approach (pp. 282-309). Oxford: Blackwell Scientific Publications.

DEAG, J. M. (1981). O comportamento social dos animais. São Paulo: EPU.

DE WAAL, F. B. M. \& SERES, M. (1997). Propagation of handclasp grooming among captive chimpanzees. American Journal of Primatology, 43, 339-346.

DUNBAR, R. I. M. (1993). Coevolution of neocortical size, group size and language in humans. Behavioral and Brain Sciences, 16, 681-735.

ECKERMAN, C. O. \& DIDOW, S. M. (1996). Nonverbal imitation and toddlers' mastery of verbal means of achieving coordinated action. Developmental Psychology, 32 (1), 141-152.

ECKERMAN, C. O. \& PETERMAN, K. (2001). Peers and infant social/communicative development. In G. Bremner \& A. Fogel (eds.), Blackwell Handbook of Infant Development (pp. 326-350). Oxford, UK: Blackwell.

ECKERMAN, C. O., DAVIS, C. C. \& DIDOW, S. M. (1989). Toddler's emerging ways of achieving social coordinations with a peer. Child Development, 60, 440-453.

EIBL-EIBESFELDT, I. (1989). Human Ethology. New York: Aldine de Gruyter.

FIAMENGHI, G. A. (1999). Conversas dos Bebês. São Paulo: Hucitec.

FIELD, T. (1989). Individual and maturational differences in infant expressivity. In N. Eisenberg (Ed.) New Directions for Child Development, no. 44 (pp. 9-23). San Francisco: Jossey-Bass.

FRANCHI E VASCONCELOS, C. R.; AMORIM, K. S.; ANJOS, A. M. \& ROSSETTI FERREIRA, M. C.(no prelo). A incompletude como virtude: interação de bebês na creche. Psicologia: Reflexão e Crítica.

GARDNER, B.T., \& GARDNER, R.A. (1984). A vocabulary test for chimpanzees. Journal of Comparative Psychology, 98, 381-404.

GOOdenough, J.; MCGUIRE, B. \& WALLACE, R. A. (1993). Perspectives on Animal Behavior. New York: John Wiley \& Sons, Inc.

GOSSO, Y. (2004). Pexe Oxemoarai: Brincadeiras Infantis Entre os Índios Parakanã. Tese apresentada ao Instituto de Psicologia da Universidade de São Paulo.

GOSSO, Y. \& OTTA, E. (2003). Em uma aldeia Parakanã. In A. M. Carvalho, C. M. C. Magalhães, F. A. R. Pontes e I. D.Bichara (Orgs.), Brincadeira e Cultura: Viajando Pelo Brasil que Brinca.(pp. 33-76) São Paulo: Casa do Psicólogo. Vol. 1. 
HARRIS, P. L. (1996). Criança e Emoção. Cap. 1 (pp. 5-26). São Paulo: Martins Fontes.

HAUSER, M. D. (1996). The Evolution of Communication. Cambridge, MA: Bradford/ MIT Press.

HERMAN, L. M. (1987). Receptive competencies of language-trained animals. In Rosenblatt, J. S., Beer, C., Busnel, M. C. \& Slater, P. J. B. (eds.), Advances in the study of behavior ( pp. 1-60) vol. 17. Academic Press, New York.

HEYES, C.M. (1993). Imitation, culture and cognition. Animal Behaviour, 46, 999-1010.

HINDE, R.A. (1974). Biological Bases of Human Social Behaviour. New York: McGraw-Hill.

KAWAMURA, S. (1959). The process of subcultural propagation among Japanese macaques. Primates, 2, 4360.

KREBS, J.R. \& DAWKINS, R. (1984). Animal signals: Mind-reading and manipulation. In J. R. Krebs \& N. B. Davis (eds.), Behavioural Ecology: An Evolutionary Approach (pp.380-402). Sunderland, MA: Sinauer Associates.

LAPIERRE, A \& LAPIERRE, A. (2002). O Adulto Diante da Criança de 0 a 3 anos - Psicomotricidade Relacional e Formação da Personalidade. Curitiba: Editora UFPR.

LEE, C.L. (2004). Comportamentos Não Verbais e Interação Social em Crianças Pré-Escolares: Comparação Entre Contextos Sócio-Afetivos de Desenvolvimento. Tese apresentada ao Instituto de Psicologia da Universidade de São Paulo.

MAINARDI, D. \& MAINARDI, M. (1988). Culture and genetics in the house mouse. In T. R. Zentall \& B .G. Galef, Jr. (eds.) Social Learning - Psychological and Biological Perspectives (pp. 239-252). Hillsdale, NJ: LEA, Publishers.

MATSUZAWA, T.(1985). Use of numbers by a chimpanzee. Nature, 315, 57-59.

MATURANA R., H \& VARELA G., F. (1995). A Árvore do Conhecimento - As Bases Biológicas do Entendimento Humano. São Paulo: Editorial Psy II.

MATURANA, R. H. (1998). Linguagem e realidade: a origem do humano. In García, J.L. (Org.), Da Biologia À Psicologia (pp. 95-101). Porto Alegre: Artes Médicas.

MATURANA R., H. (1999). Biologia do fenômeno social. In C. Magro; M. Graciano \& N. Vaz (Orgs.) A Ontologia da Realidade. Belo Horizonte: Editora UFMG. $1^{\text {a }}$ reimpressão.

MATURANA, R. H \& VARElA G., F. (2004). A Árvore do Conhecimento - As Bases Biológicas da Compreensão Humana. São Paulo: Palas Athena. 
MATURANA, R. H \& VARELA G., F. (1995). A Árvore do Conhecimento - As Bases Biológicas do Entendimento Humano. São Paulo: Editorial Psy II.

MAYNARD-SMITH, J. (1976). Evolution and the theory of games. American Scientist, 64, 41-45.

MEIRELES C. (1990). Ou Isto ou Aquilo. Rio de Janeiro: Nova Fronteira. Pp. 39.

MICHAELIS (1998). Moderno dicionário da língua portuguesa.São Paulo: Companhia Melhoramentos.

MILLER, G. A.. (1976). Comunicação não verbal. In G A Miller (Org.), Linguagem, Psicologia e Comunicação. (pp. 248-257). São Paulo: Cultrix.

MORAIS, M.L.S. (2004). Conflitos e(m) Brincadeiras Infantis: Diferenças Culturais e de Gênero. Tese apresentada ao Instituto de Psicologia da Universidade de São Paulo.

MORAIS, M. L. S. \& OTTA, E. (2003). Entre a serra e o mar. In A. M. Carvalho, C. M. C. Magalhães, F. A. R. Pontes \& I. D.Bichara (Orgs.), Brincadeira e Cultura: Viajando Pelo Brasil que Brinca.( pp. 127-156). São Paulo: Casa do Psicólogo. Vol. 1.

MORIN, E. (1973). O Paradigma Perdido: A Natureza Humana. Cap. 2 (pp. 63-78). Portugal: Publicações Europa América.

MILES, H.L. (1983). Apes and language. In J. Luce \& H. T. Wilder (Eds.), Language in Primates (pp. 43-61) New York: Springer-Verlag.

NADEL, J. (2002). Imitation and imitation recognition: Functional use in preverbal infants and nonverbal children with autism. In A. N. Meltzoff \& W.Prinz (Eds), The Imitative Mind: Development, Evolution, and Brain Bases.(pp.42-62). Cambridge: Cambridge University Press.

NAGY, E. (2006). From Imitation to Conservation: The First Dialogues with Human Neonates. Infant and Child Development. 15: 223-232

OTTONI, E.B. (2000). EthoLog 2.2: A tool for the transcription and timing of behavior observation sessions. Behavior Research Methods, Instruments, \& Computers, 32 (3), 446-449.

PAPALIA, D.E.,OLDS, S.W. \& FELDMAN,R.D. (2006).Desenvolvimento congnitivo nos três primeiros anos. In D. E. Papalia, S. W. Olds \& R. D. Feldman (Orgs), Desenvolvimento Humano (pp.186-226). $8^{\mathrm{a}}$ ed. Porto Alegre: Artmed.

PARKER, S.T. (1984). Playing for keeps: an evolutionary perspective on human games. In P.K. Smith (Ed.) Play in Animals and Humans.(pp. 271-293).Oxford, UK: Basil Blackwell

PATTERSON, F. G. (1978). Linguistic capabilities of lowland gorilla. In F.C.C. Peng (Ed.) Sign Language and Language Acquisition in Man and Ape (pp. 161-201). Boulder, CO: Westview Press. 
PEDROSA, M. I. (1989). Interação Criança-Criança: um Lugar de Construção do Sujeito. Tese de Doutoramento, Psicologia, Universidade de São Paulo, São Paulo.

PEDROSA, M. I. \& CARVALHO, A. M. A. (1995). A interação social e a construção da brincadeira. Cadernos de Pesquisa, 93, 60-65.

PEDROSA, M. I. \& CARVALHO, A .M. A. (2002). Aprendendo sobre eventos físicos com parceiros de idade. In: IX Simpósio de Pesquisa e Intercâmbio Científico. Anais da ANPEPP (Associação Nacional de Pesquisa e Pós-Graduação em Psicologia); v.1, 173-174. Rio de Janeiro: ANPEPP.

PEDROSA, M. I. \& CARVAlHO, A. M. A. (submetido). Construction of communication during play. International Journal of Qualitative Studies in Education.

PEDROSA, M. I.; CARVALHO, A. M .A. \& IMPÉRIO-HAMBURGER, A. (1997) From disordered to ordered movement: Attractor configuration and development. In A. Fogel; M. Lyra \& J. Valsiner (Eds.) Dynamics and Indeterminism in Developmental and Social Processes (pp. 135-151). Mahwah, NJ: LEA, Inc. Publishers.

PEDROSA, M. I. \& ECKERMAN, C. O. (2000). Sharing means: How infants construct joint action from movement, space, and objects. In International Society for the Study of Behavioral Development (ISSBD) (Ed.), Abstracts of the XVI ${ }^{\text {th }}$ Biennial Meetings of ISSBD (pp. 438). Beijing, China: ISSBD.

PEPPERBERG, I. M. (1994). Vocal learning in Grey parrots (Psittacus erithacus): effects of social interaction, reference, and context. Auk, 111 (2), 300-313.

PREMACK, D. (1983). The codes of man and beasts. Behavioral and Brain Sciences, 6, 125-167.

SAVAGE-RUMBAUGH, E. S., RUMBAUGH, D. M., SMITH, S.T. \& LAWSON, J. (1980). Reference: The linguistic essential. Science, 210, 922-925.

SCHUSTERMAN, R. J. \& KRIEGER, K. (1984). California sea lions are capable of semantic comprehension. Psychological Record, 34, 3-23.

SETZ, E .Z .F. (1991). Métodos de quantificação de comportamento de primatas em estudos de campo. $A$ Primatologia no Brasil, 3, 411-435.

SILVA, M. J. P. (1996). Comunicação tem remédio: a comunicação nas relações interpessoais em saúde. São Paulo: Gente.

SIMÃO, L. M. (2001). Boesch's Symbolic Action Theory in Interaction. Culture \& Psychology, 7(4), 485493. 
SIMÃO, L. M. (2002). A Noção de Objeto e a Concepção de Sujeito em Boesch. In: L.M. Simão, M.T.C.C. de Souza e N.E. Coelho Júnior, Noção de Objeto, Concepção de Sujeito: Freud, Piaget e Boesch. São Paulo: Casa do Psicólogo. Pp. 87-117.

STAMBACK, M. \& VERBA, M. (1986). Organization of social play among toddlers: An ecological approach. In E. Mueller \& C. Cooper (Eds.) Process and Outcome in Peer Relationships (pp. 229-247). New York: Academic Press.

TOMASEllo, M. (2003). Origens Culturais da Aquisição do Conhecimento Humano. São Paulo: Martins Fontes.

TOMASEllo, M., CARPENTER, M., CALL, J., BEHNE, T., \& MOLL, H.(2005).Understanding and sharing intentions:The origins of cultural cognition. Behavioral and brain sciences, 28, 675-735. 


\section{APÊNDICE}




\section{APÊNDICE 1 - Modelo do termo de consentimento livre e esclarecido.}

\section{CONSENTIMENTO PÓS-INFORMAÇÃO}

Consinto que meu filho(a) participe do projeto de pesquisa "Interação Social e Comunicação na Primeira Infância", após ser informado(a) que esse trabalho tem por objetivo investigar os processos de interação social e comunicação que ocorrem entre crianças de 1 a 3 anos de idade, em momentos de brincadeira livre (isto é, sem a interferência de adultos).

Tenho conhecimento de que este trabalho de pesquisa utiliza a gravação em vídeo da brincadeira de crianças de 1 a 3 anos de idade, no ambiente da Educação Infantil. Sei que a participação do meu filho(a) na pesquisa não me trará danos ou despesas.

Tendo em vista esses objetivos, concordo em permitir a participação do meu filho(a), autorizando:

1- A filmagem do meu filho(a), em fitas de vídeo, sem qualquer identificação do seu nome.

2- A apresentação de fotos e/ou vídeos em publicações escritas do trabalho e apresentações em congressos científicos, sem a identificação do nome.

Sei que a qualquer momento posso desistir de deixar meu filho(a) participar dessa pesquisa, sem que essa decisão traga qualquer conseqüência para a criança na creche.

São Paulo, de de

Nome da criança:

Responsável legal pela criança: 
Pesquisadora:

\section{Endereço para contato}

Orientadora:

Pesquisadora:

Endereço:

Fone: 


\section{APÊNDICE 2 - Pares de objetos, iguais e diferentes, utilizados em cada uma das fases}

de observações em situação semicontrolada.

\begin{tabular}{|c|c|c|c|c|c|c|}
\hline Pares de objetos & \multicolumn{6}{|c|}{ Fases } \\
\hline Iguais (i) & $\mathbf{1}^{\mathrm{a}}$ & $\mathbf{2}^{\mathrm{a}}$ & $\mathbf{3}^{\mathbf{a}}$ & $4^{\mathrm{a}}$ & $\mathbf{5}^{\mathbf{a}}$ & $\mathbf{6}^{\mathbf{a}}$ \\
\hline 1. Barris de plástico coloridos, contidos um dentro do outro. & & & & & $\mathrm{X}$ & \\
\hline 2. Bolas de plástico azul & $\mathrm{X}$ & & & & $\mathrm{X}$ & \\
\hline 3. Bolsinhas de plástico pequenas. & & & & & & $\mathrm{X}$ \\
\hline 4. Bonecas de plástico. & & & & $\mathrm{X}$ & $\mathrm{X}$ & \\
\hline $\begin{array}{l}\text { 5. Bonecos com corpo de espuma e pano, cabeça de plástico e cabelo de lã ("Bebês } \\
\text { Tikinho"). }\end{array}$ & $X$ & & $X$ & & & $\mathrm{X}$ \\
\hline 6. Caixas pequenas pintadas com guache e cheias de pedrinhas (chocalhos). & $\mathrm{X}$ & & & & & \\
\hline 7. Caixas de papelão grandes. & & & & & & $\mathrm{X}$ \\
\hline 8. Caminhões de madeira. & & $X$ & & & $X$ & \\
\hline $\begin{array}{l}\text { 9. Carrinhos de plástico (vans) com orifícios de diferentes formas geométricas e } \\
\text { peças coloridas para encaixar neles. }\end{array}$ & & & & $\mathrm{X}$ & & \\
\hline 10. Colares vermelhos. & & & & $\mathrm{X}$ & & \\
\hline 11. Cordões azuis. & & & $\mathrm{X}$ & & & \\
\hline 12. Festões dourados. & & & & & & $\mathrm{X}$ \\
\hline $\begin{array}{l}\text { 13. Garrafas pet pequenas (caçulinhas) preenchidas com água, detergente, miçangas } \\
\text { e estrelinhas. }\end{array}$ & $X$ & & & & & \\
\hline 14. Kits médicos (cada um com estetoscópio, seringa e remédio). & & & & $\mathrm{X}$ & & \\
\hline 15. Latas (de leite em pó) com uma bola de plástico (de fisioterapia) dentro. & & & $\mathrm{X}$ & & & \\
\hline 16. Módulos geométricos de madeira (com peças coloridas). & & & & & $\mathrm{X}$ & \\
\hline 17. Molas de plástico coloridas. & & $\mathrm{X}$ & & & & \\
\hline 18. Peças de madeira coloridas (“Multiblock"). & & & $\mathrm{X}$ & $\mathrm{X}$ & & \\
\hline 19. Potes de iogurte. & & $\mathrm{X}$ & & & & \\
\hline 20. Potes de plástico com tampa e pedrinhas dentro (chocalhos). & & $\mathrm{X}$ & & & & \\
\hline 21. Sacos azuis pequenos de juta. & & & & & & $\mathrm{X}$ \\
\hline 22. Serpentinas. & & $\mathrm{X}$ & & & & \\
\hline 23. Telefones de plástico & $\mathrm{X}$ & & & & & \\
\hline 24. Tubos compridos de papelão. & & & $\mathrm{X}$ & & & \\
\hline Diferentes (d) & & & & & & \\
\hline 1. Bambolês, um verde, outro laranja. & & & & & $\mathrm{X}$ & \\
\hline $\begin{array}{l}\text { 2. Bandejas brancas, uma de plástico, outra de isopor (para colocar as peças de } \\
\text { plástico). }\end{array}$ & & & $\mathrm{X}$ & & & \\
\hline 3. Bichos de pelúcia: um elefante e um urso polar. & & $\mathrm{X}$ & & & & \\
\hline 4. Bóias de cintura, uma vermelha, outra azul. & & & & & & $\mathrm{X}$ \\
\hline 5. Bolas de plástico (utilizadas em fisioterapia), uma verde, outra vermelha. & & & & $\mathrm{X}$ & & \\
\hline 6. Bonecos pequenos e articulados (menino e menina), feitos com arame e corda. & & & & & & $\mathrm{X}$ \\
\hline 7. Caixas de papelão de tamanhos diferentes. & & & & & $\mathrm{X}$ & \\
\hline 8. Cangas, uma vermelha e outra azulada. & & & $\mathrm{X}$ & & & \\
\hline 9. Cestas de vime, uma oval e outra redonda (para colocar as peças de madeira). & & & $\mathrm{X}$ & & & \\
\hline 10. Chapéus, um preto, outro azul. & & $\mathrm{X}$ & & & & \\
\hline 11. Dois livros diferentes de estórias infantis pequenos (com vários desenhos). & & $\mathrm{X}$ & & & & \\
\hline 12. Duas sacolas de feira pequenas com motivos e cores diferentes. & $\mathrm{X}$ & & & $\mathrm{X}$ & & \\
\hline $\begin{array}{l}\text { 13. Duas casinhas de plástico com orifícios de diferentes formas geométricas e peças } \\
\text { coloridas para encaixar neles. A combinação de cores das casinhas é diferente. }\end{array}$ & & & & & & $\mathrm{X}$ \\
\hline $\begin{array}{l}\text { 14. Fantoches de patos de pelúcia, um rosa, outro amarelo, com "buzina" e língua de } \\
\text { sogra no bico. }\end{array}$ & & & & & $\mathrm{X}$ & \\
\hline 15. Fantoches, um de macaco, outro de cachorro. & & & & $\mathrm{X}$ & & \\
\hline 16. Feltros (cerca de $0,5 \mathrm{~m}^{2}$ ), um vermelho, outro amarelo. & & & & & $\mathrm{X}$ & $\mathrm{X}$ \\
\hline
\end{tabular}


Continuação

\begin{tabular}{|c|c|c|c|c|c|c|}
\hline Pares de objetos & \multicolumn{6}{|c|}{ Fases } \\
\hline Diferentes (d) & $\mathbf{1}^{\mathrm{a}}$ & $\mathbf{2}^{\mathrm{a}}$ & $3^{\mathbf{a}}$ & $4^{a}$ & $5^{\mathbf{a}}$ & $\mathbf{6}^{\mathbf{a}}$ \\
\hline $\begin{array}{l}\text { 17. Garrafas pet pequenas ("caçulinhas") preenchidas com água, detergente, } \\
\text { miçangas e estrelinhas, mas uma delas com o líquido azul (tinta guache). }\end{array}$ & & & & & $\mathrm{X}$ & \\
\hline 18. Lanternas pequenas, uma amarela e outra rosa. & $\mathrm{X}$ & & & & & \\
\hline 19. Lenços floridos, um rosa e outro verde. & $\mathrm{X}$ & & & $\mathrm{X}$ & & \\
\hline 20. Óculos de plástico, um azul, outro rosa. & & $\mathrm{X}$ & $\mathrm{X}$ & & & \\
\hline $\begin{array}{l}\text { 21. Peças de plástico coloridas, de encaixar; um conjunto dava para montar um } \\
\text { elefante e o outro um cavalo. }\end{array}$ & & & $\mathrm{X}$ & & & \\
\hline 22. Quebra-cabeças (palhaço) de EVA com cores diferentes. & & $\mathrm{X}$ & & & & \\
\hline 23. Roupas de boneca: um vestido e uma blusa de tricô. & & & & $\mathrm{X}$ & & \\
\hline 24. Trem e caminhão de plástico com peças de encaixar (tipo quebra-cabeças). & & & & & & $\mathrm{X}$ \\
\hline 25. Tubos de papelão pintados, um representando o dia e o outro a noite. & $\mathrm{X}$ & & & & & \\
\hline $\begin{array}{l}\text { 26. Um conjunto de seis blocos de encaixar coloridos (tipo Lego) com peças grandes } \\
\text { e outro com médias. }\end{array}$ & $\mathrm{X}$ & & & & & \\
\hline
\end{tabular}




\section{APÊNDICE 3 - Quadro resumo do procedimento utilizado em cada tipo de sessão de observação e dos objetivos de análise correspondentes.}

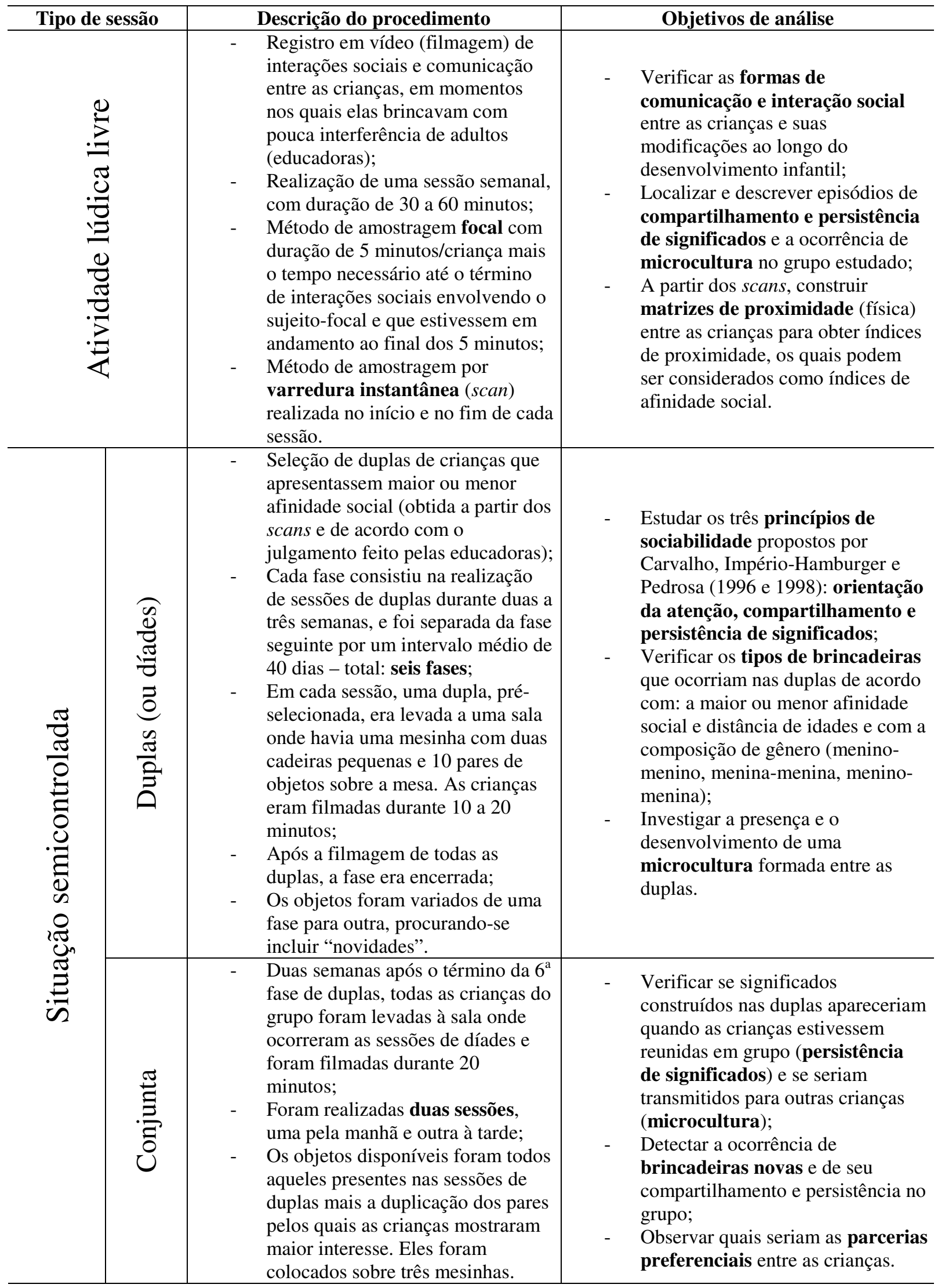




\section{APÊNDICE 4 - Quadro da seqüência de períodos dos tipos de sessões de observação} realizadas ao longo do tempo de coleta de dados da pesquisa (agosto de 2003 a dezembro de 2004).

\begin{tabular}{|c|c|}
\hline Período & Tipo de sessão de observação \\
\hline 14/8/03 - 4/3/04 (26 semanas) & Atividade lúdica livre (ALL) \\
\hline $10,11,17$ e $18 / 3 / 04$ (duas semanas) & Duplas: $1^{\mathrm{a}}$ fase (D1) \\
\hline 25/3-28/4/04 (seis semanas) & Atividade lúdica livre (ALL) \\
\hline $5,6,12,13$ e $14 / 5 / 04$ (duas semanas) & Duplas: $2^{\mathrm{a}}$ fase (D2) \\
\hline $20 / 5-16 / 6 / 04$ (cinco semanas) & Atividade lúdica livre (ALL) \\
\hline $23,24,30 / 6$ e $1 / 7 / 04$ (duas semanas) & Duplas: $3^{\mathrm{a}}$ fase (D3) \\
\hline $8 / 7-4 / 8 / 04$ (cinco semanas) & Atividade lúdica livre (ALL) \\
\hline 11,12 e $18 / 8 / 04$ (duas semanas) & Duplas: $4^{\mathrm{a}}$ fase (D4) \\
\hline $25 / 8-22 / 9 / 04$ (cinco semanas) & Atividade lúdica livre (ALL) \\
\hline $29,30 / 9,6,7$ e $14 / 10 / 04$ (três semanas) & Duplas: $5^{\mathrm{a}}$ fase (D5) \\
\hline $14 / 10 / 04$ & Conjunta (Cj.)- piloto \\
\hline $20 / 10-16 / 11 / 04$ (cinco semanas) & Atividade lúdica livre (ALL) \\
\hline $23,25,30 / 11$ e $2 / 12 / 04$ (duas semanas) & Duplas: $6^{\mathrm{a}}$ fase (D6) \\
\hline $16 / 12 / 04$ & Conjuntas $(\mathrm{Cj})$.1 e 2 \\
\hline
\end{tabular}

Nota: Foi realizada apenas uma sessão por semana de "atividade lúdica livre".

Síntese da seqüência de realização de cada tipo de sessão de observação:

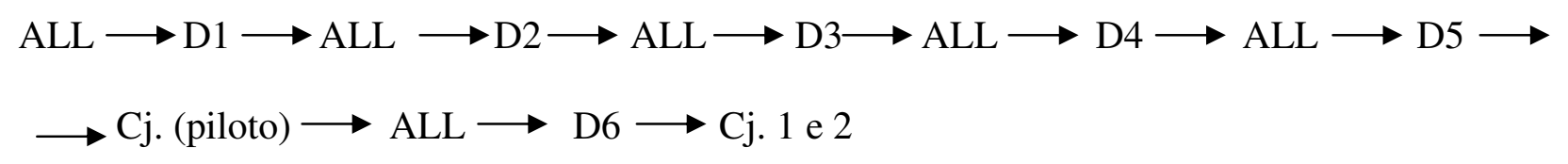


APÊNDICE 5 - Freqüência absoluta (Fa) e relativa (Fr) de cada par de crianças observadas próximas nos scans considerados para cada fase de duplas. (Em destaque, estão os dois valores menores e os dois maiores).

\begin{tabular}{|c|c|c|c|c|c|c|c|c|c|c|c|c|}
\hline \multirow{2}{*}{ Pares } & \multicolumn{2}{|c|}{$1^{a}$ fase $^{I}$} & \multicolumn{2}{|c|}{$2^{\mathrm{a}}$ fase $^{\mathrm{II}}$} & \multicolumn{2}{|c|}{$3^{\text {a }}$ fase $^{\text {III }}$} & \multicolumn{2}{|c|}{$4^{\mathrm{a}}$ fase $^{\mathrm{IV}}$} & \multicolumn{2}{|c|}{$5^{a}$ fase $^{V}$} & \multicolumn{2}{|c|}{$6^{\mathrm{a}}$ fase $^{\mathrm{VI}}$} \\
\hline & Fa & $\operatorname{Fr}(\%)$ & Fa & $\operatorname{Fr}(\%)$ & Fa & $\operatorname{Fr}(\%)$ & $\mathbf{F a}$ & $\operatorname{Fr}(\%)$ & $\mathbf{F a}$ & $\operatorname{Fr}(\%)$ & $\mathbf{F a}$ & $\operatorname{Fr}(\%)$ \\
\hline A-B & - & - & - & - & - & - & - & - & 0 & 0 & 0 & 0 \\
\hline A-C & 2 & 4 & 2 & 6 & 2 & 7 & 0 & 0 & 2 & 10 & 4 & 18 \\
\hline A-Gi & 7 & 15 & 1 & 3 & 2 & 7 & 3 & 15 & 3 & 15 & 3 & 14 \\
\hline A-Gu & - & - & 0 & 0 & 2 & 7 & 3 & 15 & 1 & 5 & 1 & 5 \\
\hline A-H & 1 & 2 & 1 & 3 & 3 & 11 & 4 & 20 & 2 & 10 & 0 & 0 \\
\hline A-La & 4 & 8 & 1 & 3 & 0 & $\mathbf{0}$ & 1 & 5 & 3 & 15 & 4 & 18 \\
\hline A-Li & - & - & - & - & - & - & - & - & - & - & 3 & 14 \\
\hline A-M & 3 & 6 & 5 & 14 & - & - & - & - & - & - & - & - \\
\hline A-S & 6 & 13 & 6 & 17 & 7 & 25 & 2 & 10 & 1 & 5 & 1 & 5 \\
\hline B-C & - & - & - & - & - & - & - & - & 0 & 0 & 1 & 5 \\
\hline B-Gi & - & - & - & - & - & - & - & - & 2 & 10 & 3 & 14 \\
\hline B-Gu & - & - & - & - & - & - & - & - & 4 & 20 & 5 & 23 \\
\hline B-H & - & - & - & - & - & - & - & - & 2 & 10 & 3 & 14 \\
\hline B-La & - & - & - & - & - & - & - & - & 1 & 5 & 3 & 14 \\
\hline B-Li & - & - & - & - & - & - & - & - & - & - & 0 & 0 \\
\hline B-S & - & - & - & - & - & - & - & - & 0 & 0 & 1 & 5 \\
\hline C-Gi & 3 & 6 & 5 & 14 & 4 & 14 & O & 0 & 1 & 5 & 2 & 9 \\
\hline C-Gu & - & - & 2 & 6 & 2 & 7 & 2 & 10 & 2 & 10 & 2 & 9 \\
\hline C-H & 8 & 17 & 8 & 22 & 5 & 18 & 3 & 15 & 3 & 15 & 7 & 32 \\
\hline C-La & 5 & 10 & 5 & 14 & 3 & 11 & 0 & 0 & 2 & 1 & 3 & 14 \\
\hline $\mathrm{C}-\mathrm{Li}$ & - & - & - & - & - & - & - & - & - & - & 0 & 0 \\
\hline C-M & 1 & 2 & 3 & 8 & 3 & 11 & - & - & - & - & - & - \\
\hline C-S & 8 & 17 & 7 & 19 & 5 & 18 & 3 & 15 & 2 & 10 & 2 & 9 \\
\hline Gi-Gu & - & - & 0 & 0 & 0 & 0 & 1 & 5 & 2 & 10 & 4 & 18 \\
\hline Gi-H & 7 & 15 & 5 & 14 & 4 & 14 & 5 & 25 & 4 & 20 & 4 & 18 \\
\hline Gi-La & 9 & 19 & 8 & 22 & 7 & 25 & 1 & 5 & 1 & 10 & 1 & 5 \\
\hline Gi-Li & - & - & - & - & - & - & - & - & - & - & 0 & 0 \\
\hline Gi-M & 2 & 4 & 2 & 6 & 1 & 4 & - & - & - & - & - & - \\
\hline Gi-S & 6 & 13 & 3 & 8 & 2 & 7 & 1 & 5 & 2 & 10 & 2 & 9 \\
\hline Gu-H & - & - & 1 & 3 & 1 & 4 & 1 & 5 & 1 & 5 & 1 & 5 \\
\hline Gu-La & - & - & 0 & 0 & 0 & O & 0 & 0 & 2 & 10 & 3 & 14 \\
\hline Gu-Li & - & - & - & - & - & - & - & - & - & - & 0 & 0 \\
\hline Gu-M & - & - & 1 & 3 & 1 & 4 & - & - & - & - & - & - \\
\hline Gu-S & - & - & 0 & 0 & 2 & 7 & 2 & 10 & $\mathbf{0}$ & 0 & 1 & 5 \\
\hline H-La & 9 & 19 & 4 & 11 & 1 & 4 & 1 & 5 & 3 & 15 & 3 & 14 \\
\hline H-Li & - & - & - & - & - & - & - & - & - & - & 1 & 5 \\
\hline H-M & 1 & 2 & 4 & 11 & 5 & 18 & - & - & - & - & - & - \\
\hline H-S & 6 & 13 & 2 & 6 & 3 & 11 & 3 & 15 & 3 & 15 & 3 & 14 \\
\hline La-Li & - & - & - & - & - & - & - & - & - & - & 0 & 0 \\
\hline La-M & 2 & 4 & 1 & 3 & 1 & 4 & - & - & - & - & - & - \\
\hline La-S & 4 & 8 & 3 & 8 & 2 & 7 & 0 & 0 & 0 & 0 & 0 & 0 \\
\hline Li-S & - & - & - & - & - & - & - & - & - & - & 1 & 5 \\
\hline M-S & 1 & 2 & 1 & 3 & 0 & 0 & - & - & - & - & - & - \\
\hline
\end{tabular}


Nota: Número de scans considerados em cada fase ${ }^{16}:$ I -48 (todos os anteriores à $1^{\mathrm{a}}$ fase); II - 36 (posteriores à entrada de Meire e anteriores à $2^{\mathrm{a}}$ fase); III - 28 (os posteriores à entrada de Gustavo e os anteriores a ela mais recentes, em igual número); IV - 20 (os compreendidos entre a $3^{\mathrm{a}}$ e a $4^{\mathrm{a}}$ fase e igual número dos anteriores à $3^{\mathrm{a}}$ fase mais recentes); V - 20 (os compreendidos entre a $4^{\mathrm{a}}$ e a $5^{\mathrm{a}}$ fase e igual número dos anteriores à $4^{\mathrm{a}}$ fase mais recentes); VI - 22 (os compreendidos entre a $5^{\mathrm{a}}$ e a $6^{\mathrm{a}}$ fase e os 10 anteriores à $5^{\mathrm{a}}$ fase mais recentes).

${ }^{16}$ Não foram considerados apenas os scans mais recentes anteriores a cada fase, porque a amostra seria pequena. Além disso, existe uma história de relações no grupo, portanto não há problema em considerar scans um pouco mais "antigos". 
APÊNDICE 6 - Pares de crianças que brincavam mais (+) ou menos (-) juntas, segundo o julgamento das educadoras que as acompanhavam, em cada fase. (Pares na ordem em que foram citados; em destaque, a concordância entre as educadoras).

\begin{tabular}{|c|c|c|c|c|c|c|c|c|c|c|}
\hline \multirow{2}{*}{ Educadoras } & \multicolumn{2}{|c|}{$2^{a}$ fase } & \multicolumn{2}{|c|}{$3^{\text {a }}$ fase } & \multicolumn{2}{|c|}{$4^{\mathrm{a}}$ fase } & \multicolumn{2}{|c|}{$5^{\mathrm{a}}$ fase } & \multicolumn{2}{|c|}{$6^{\text {a }}$ fase } \\
\hline & + & - & + & - & + & - & + & - & + & - \\
\hline $\mathbf{E}_{1}$ & $\begin{array}{l}\text { Gi-S; } \\
\text { Gi-M }\end{array}$ & $\begin{array}{c}\mathbf{H} ; \mathbf{A} ; \\
\text { A-H }\end{array}$ & $\begin{array}{c}\text { C-S; } \\
\text { A-Gi; } \\
\text { C-H; } \\
\text { H-S; } \\
\text { Gi-La; } \\
\text { Gu-La }\end{array}$ & $\begin{array}{l}\text { A-La; } \\
\text { A-H }\end{array}$ & C-S & $\begin{array}{c}\mathrm{B} ; \mathrm{Gu} \\
\mathrm{H}\end{array}$ & -- & -- & $\begin{array}{c}\text { A-Li; } \\
\text { B-Li; } \\
\text { C-S; } \\
\text { Gu }\end{array}$ & $\begin{array}{c}\mathbf{H} ; \\
\text { Gi-La; } \\
\text { Gi-Li }\end{array}$ \\
\hline $\mathbf{E}_{2}$ & $\begin{array}{l}\text { C-Gi; } \\
\text { Gi-La; } \\
\text { C-La; } \\
\text { La-S; } \\
\text { H-La }\end{array}$ & $\begin{array}{c}\mathbf{H} ; \\
\mathbf{H - S} ; \\
\text { C-M }\end{array}$ & $\begin{array}{c}\text { Gi-La; } \\
\text { C-S; } \\
\text { Gu-H }\end{array}$ & $\begin{array}{l}\text { C-La; } \\
\text { A-La }\end{array}$ & -- & -- & -- & -- & -- & -- \\
\hline $\mathbf{E}_{3}$ & $\begin{array}{l}\text { C-Gi; } \\
\text { Gi-La }\end{array}$ & $\begin{array}{l}\text { A; H; } \\
\text { H-S; } \\
\text { A-C }\end{array}$ & $\begin{array}{l}\text { C-Gi; } \\
\text { A-Gu }\end{array}$ & $\begin{array}{l}\text { A-La; } \\
\text { Gi-La }\end{array}$ & $\mathrm{C}-\mathrm{H}$ & $\begin{array}{c}\mathrm{C} ; \mathrm{S} ; \\
\mathrm{C}-\mathrm{S} ; \mathrm{Gi}\end{array}$ & -- & -- & -- & -- \\
\hline $\mathbf{E}_{4}$ & -- & -- & C-Gi & A-H & -- & -- & $\mathrm{H}-\mathrm{S}$ & B-La & -- & -- \\
\hline $\mathbf{E}_{5}$ & -- & -- & -- & -- & Gi-La & B-H & Gi-La & B-La & $\begin{array}{c}\mathrm{Li} \\
\text { B-Li; } \\
\text { A-Li }\end{array}$ & $\begin{array}{c}\mathbf{H} ; \\
\text { B-La }\end{array}$ \\
\hline
\end{tabular}

Nota:

- Os traços representam que a educadora estava ausente no período que antecedeu a fase de duplas (férias ou remanejamento temporário dentro da creche);

- As educadoras $\mathrm{E}_{2}$ e $\mathrm{E}_{3}$ pararam de trabalhar na creche;

- O nome de uma criança citado sozinho indica que a educadora a via sozinha a maior parte do tempo (em -) ou brincando com todas as crianças (em + ). 
APÊNDICE 7 - Número de comportamentos não-verbais indicativos de comunicação emitidos pelas crianças nos focais iniciais (21/8/03

a 22/9/03) de A, C, Gi, H, La e S.

\begin{tabular}{|c|c|c|c|c|c|c|c|}
\hline Não-verbal emitido / Referência & Própria criança & Outra(s) criança(s) & Educadora & Pesquisadora & Referência desconhecida & Pessoa ausente & TOTAL \\
\hline Olhares & $\begin{array}{c}\mathbf{0} \\
\end{array}$ & 103 & 7 & 12 & \begin{tabular}{|c|}
$\mathbf{0}$ \\
\end{tabular} & $\begin{array}{l}\mathbf{0} \\
\end{array}$ & 122 \\
\hline Olhar/observar & 0 & 86 & 7 & 12 & 0 & 0 & 105 \\
\hline Olhar recíproco & 0 & 17 & 0 & 0 & 0 & 0 & 17 \\
\hline Contatos amistosos & $\mathbf{0}$ & 16 & 1 & $\mathbf{0}$ & $\mathbf{0}$ & $\mathbf{0}$ & 17 \\
\hline Contato corporal & 0 & 10 & 0 & 0 & 0 & 0 & 10 \\
\hline Acariciar & 0 & 2 & 0 & 0 & 0 & 0 & 2 \\
\hline Abraçar, beijar & 0 & 3 & 0 & 0 & 0 & 0 & 3 \\
\hline Dar a mão para & 0 & 0 & 1 & 0 & 0 & 0 & 1 \\
\hline Puxar a mão do outro & 0 & 1 & 0 & 0 & 0 & 0 & 1 \\
\hline Expressões corporais & $\mathbf{0}$ & 30 & 2 & 3 & 1 & $\mathbf{0}$ & 36 \\
\hline Movimento do corpo & 0 & 6 & 1 & 0 & 1 & 0 & 8 \\
\hline Expressão corporal de braveza & 0 & 7 & 1 & 3 & 0 & 0 & 11 \\
\hline Virar o corpo de frente para & 0 & 6 & 0 & 0 & 0 & 0 & 6 \\
\hline Virar o corpo de costas para & 0 & 7 & 0 & 0 & 0 & 0 & 7 \\
\hline Separar briga entre duas crianças & 0 & 1 & 0 & 0 & 0 & 0 & 1 \\
\hline Expressões corporais de excitação & 0 & 2 & 0 & 0 & 0 & 0 & 2 \\
\hline Bater palmas & 0 & 1 & 0 & 0 & 0 & 0 & 1 \\
\hline Gestos e acenos & $\mathbf{0}$ & 15 & 13 & 1 & 3 & $\mathbf{0}$ & 32 \\
\hline Balançar vertical da cabeça ("sim") & 0 & 0 & 0 & 0 & 0 & 0 & 0 \\
\hline Balançar horizontal da cabeça ("não") & 0 & 0 & 0 & 0 & 0 & 0 & 0 \\
\hline Estender o braço (pedido) & 0 & 3 & 4 & 1 & 0 & 0 & 8 \\
\hline Estender objeto para & 0 & 3 & 7 & 0 & 0 & 0 & 10 \\
\hline Segurar e mostrar um objeto & 0 & 2 & 0 & 0 & 0 & 0 & 2 \\
\hline Apontar & 0 & 0 & 2 & 0 & 0 & 0 & 2 \\
\hline Aceno de despedida & 0 & 0 & 0 & 0 & 1 & 0 & 1 \\
\hline Sinal de "não" com o dedo indicador & 0 & 0 & 0 & 0 & 0 & 0 & 0 \\
\hline Abrir a boca (pedindo comida) & 0 & 0 & 0 & 0 & 0 & 0 & 0 \\
\hline $\begin{array}{l}\text { Levantar os braços para o alto } \\
\text { (comemorar) }\end{array}$ & 0 & 0 & 0 & 0 & 0 & 0 & 0 \\
\hline
\end{tabular}




\begin{tabular}{|c|c|c|c|c|c|c|c|}
\hline Não-verbal emitido / Referência & Própria criança & Outra(s) criança(s) & Educadora & Pesquisadora & Referência desconhecida & Pessoa ausente & TOTAL \\
\hline Fazer gesto para sentar & 0 & 3 & \begin{tabular}{|c|}
0 \\
\end{tabular} & \begin{tabular}{|c|}
0 \\
\end{tabular} & \begin{tabular}{|c|}
0 \\
\end{tabular} & 0 & 3 \\
\hline Gesto de chamar & 0 & 0 & 0 & 0 & 0 & 0 & 0 \\
\hline Gesto de interrogação/dúvida & 0 & 1 & 0 & 0 & 0 & 0 & 1 \\
\hline Gesto de confusão & 0 & 0 & 0 & 0 & 0 & 0 & 0 \\
\hline Gesto de ameaça ou de assustar & 0 & 1 & 0 & 0 & 1 & 0 & 2 \\
\hline Gesto de beber ou comer & 0 & 0 & 0 & 0 & 0 & 0 & 0 \\
\hline Gesto indefinido, atípico & 0 & 2 & 0 & 0 & 1 & 0 & 3 \\
\hline Comportamentos agonísticos & $\mathbf{0}$ & 52 & $\mathbf{0}$ & $\mathbf{0}$ & $\mathbf{0}$ & $\mathbf{0}$ & 52 \\
\hline Agonismo & 0 & 46 & 0 & 0 & 0 & 0 & 46 \\
\hline Bater de brincadeira (turbulenta) & 0 & 6 & 0 & 0 & 0 & 0 & 6 \\
\hline Expressões faciais & 3 & 54 & 12 & 5 & 8 & $\mathbf{0}$ & 82 \\
\hline Sorriso & 1 & 19 & 5 & 4 & 1 & 0 & 30 \\
\hline Riso & 2 & 21 & 4 & 0 & 6 & 0 & 33 \\
\hline Choro, choramingo & 0 & 12 & 1 & 1 & 0 & 0 & 14 \\
\hline Expressão facial específica & 0 & 2 & 2 & 0 & 1 & 0 & 5 \\
\hline Vocalizações & 14 & 54 & 6 & 2 & 20 & 1 & 97 \\
\hline Vocalização & 14 & 52 & 6 & 2 & 20 & 1 & 95 \\
\hline Vocalização alternada & 0 & 2 & 0 & 0 & 0 & 0 & 2 \\
\hline Imitação & $\mathbf{0}$ & 27 & $\mathbf{0}$ & $\mathbf{0}$ & $\mathbf{0}$ & $\mathbf{0}$ & 27 \\
\hline Imitação & 0 & 27 & 0 & 0 & 0 & 0 & 27 \\
\hline TOTAL & 17 & 351 & 41 & 23 & 32 & 1 & 465 \\
\hline
\end{tabular}


APÊNDICE 8 - Número de comportamentos não-verbais indicativos de comunicação emitidos pelas crianças nos focais intermediários

(25/3/04 a 28/4/04) de A, C, Gi, H, La e S.

\begin{tabular}{|c|c|c|c|c|c|c|c|}
\hline Não-verbal emitido / Referência & Própria criança & Outra(s) criança(s) & Educadora & Pesquisadora & Referência desconhecida & Pessoa ausente & TOTAL \\
\hline Olhares & \begin{tabular}{|c|}
$\mathbf{0}$ \\
\end{tabular} & 60 & 6 & 4 & $\begin{array}{c}\mathbf{0} \\
\end{array}$ & 0 & $\mathbf{7 0}$ \\
\hline Olhar/observar & 0 & 54 & 6 & 4 & 0 & 0 & 64 \\
\hline Olhar recíproco & 0 & 6 & 0 & 0 & 0 & 0 & 6 \\
\hline Contatos amistosos & $\mathbf{0}$ & 11 & 1 & $\mathbf{0}$ & $\mathbf{0}$ & $\mathbf{0}$ & 12 \\
\hline Contato corporal & 0 & 7 & 0 & 0 & 0 & 0 & 7 \\
\hline Acariciar & 0 & 0 & 0 & 0 & 0 & 0 & 0 \\
\hline Abraçar, beijar & 0 & 1 & 1 & 0 & 0 & 0 & 2 \\
\hline Dar a mão para & 0 & 3 & 0 & 0 & 0 & 0 & 3 \\
\hline Puxar a mão do outro & 0 & 0 & 0 & 0 & 0 & 0 & 0 \\
\hline Expressões corporais & 2 & 10 & 2 & $\mathbf{0}$ & $\mathbf{0}$ & $\mathbf{0}$ & 14 \\
\hline Movimento do corpo & 1 & 0 & 1 & 0 & 0 & 0 & 2 \\
\hline Expressão corporal de braveza & 0 & 2 & 0 & 0 & 0 & 0 & 2 \\
\hline Virar o corpo de frente para & 0 & 5 & 1 & 0 & 0 & 0 & 6 \\
\hline Virar o corpo de costas para & 0 & 2 & 0 & 0 & 0 & 0 & 2 \\
\hline Separar briga entre duas crianças & 0 & 0 & 0 & 0 & 0 & 0 & 0 \\
\hline Expressões corporais de excitação & 0 & 0 & 0 & 0 & 0 & 0 & 0 \\
\hline Bater palmas & 1 & 1 & 0 & 0 & 0 & 0 & 2 \\
\hline Gestos e acenos & 3 & 23 & 21 & 1 & 1 & $\mathbf{0}$ & 49 \\
\hline Balançar vertical da cabeça ("sim") & 0 & 0 & 1 & 0 & 0 & 0 & 1 \\
\hline Balançar horizontal da cabeça ("não") & 0 & 2 & 1 & 0 & 0 & 0 & 3 \\
\hline Estender o braço (pedido) & 0 & 1 & 3 & 0 & 0 & 0 & 4 \\
\hline Estender objeto para & 0 & 10 & 7 & 1 & 0 & 0 & 18 \\
\hline Segurar e mostrar um objeto & 0 & 1 & 0 & 0 & 0 & 0 & 1 \\
\hline Apontar & 0 & 3 & 6 & 0 & 1 & 0 & 10 \\
\hline Aceno de despedida & 0 & 0 & 0 & 0 & 0 & 0 & 0 \\
\hline Sinal de "não" com o dedo indicador & 0 & 0 & 2 & 0 & 0 & 0 & 2 \\
\hline Abrir a boca (pedindo comida) & 0 & 2 & 0 & 0 & 0 & 0 & 2 \\
\hline $\begin{array}{l}\text { Levantar os braços para o alto } \\
\text { (comemorar) }\end{array}$ & 1 & 0 & 0 & 0 & 0 & 0 & 1 \\
\hline
\end{tabular}




\begin{tabular}{|c|c|c|c|c|c|c|c|}
\hline Não-verbal emitido / Referência & Própria criança & Outra(s) criança(s) & Educadora & Pesquisadora & Referência desconhecida & Pessoa ausente & TOTAL \\
\hline Fazer gesto para sentar & 0 & 0 & \begin{tabular}{|c|}
0 \\
\end{tabular} & \begin{tabular}{|c|}
0 \\
\end{tabular} & \begin{tabular}{|c|}
0 \\
\end{tabular} & 0 & 0 \\
\hline Gesto de chamar & 0 & 0 & 0 & 0 & 0 & 0 & 0 \\
\hline Gesto de interrogação/dúvida & 1 & 0 & 0 & 0 & 0 & 0 & 1 \\
\hline Gesto de confusão & 0 & 0 & 0 & 0 & 0 & 0 & 0 \\
\hline Gesto de ameaça ou de assustar & 0 & 4 & 0 & 0 & 0 & 0 & 4 \\
\hline Gesto de beber ou comer & 1 & 0 & 1 & 0 & 0 & 0 & 2 \\
\hline Gesto indefinido, atípico & 0 & 0 & 0 & 0 & 0 & 0 & 0 \\
\hline Comportamentos agonísticos & $\mathbf{0}$ & 26 & $\mathbf{0}$ & $\mathbf{0}$ & $\mathbf{0}$ & $\mathbf{0}$ & 26 \\
\hline Agonismo & 0 & 24 & 0 & 0 & 0 & 0 & 24 \\
\hline Bater de brincadeira (turbulenta) & 0 & 2 & 0 & 0 & 0 & 0 & 2 \\
\hline Expressões faciais & 1 & 40 & 4 & 2 & 1 & $\mathbf{0}$ & 48 \\
\hline Sorriso & 1 & 9 & 1 & 0 & 1 & 0 & 12 \\
\hline Riso & 0 & 22 & 1 & 0 & 0 & 0 & 23 \\
\hline Choro, choramingo & 0 & 5 & 2 & 1 & 0 & 0 & 8 \\
\hline Expressão facial específica & 0 & 4 & 0 & 1 & 0 & 0 & 5 \\
\hline Vocalizações & 4 & 40 & 4 & $\mathbf{0}$ & $\mathbf{0}$ & $\mathbf{0}$ & 48 \\
\hline Vocalização & 4 & 40 & 4 & 0 & 0 & 0 & 48 \\
\hline Vocalização alternada & 0 & 0 & 0 & 0 & 0 & 0 & 0 \\
\hline Imitação & $\mathbf{0}$ & 18 & $\mathbf{0}$ & $\mathbf{0}$ & $\mathbf{0}$ & $\mathbf{0}$ & 18 \\
\hline Imitação & 0 & 18 & 0 & 0 & 0 & 0 & 18 \\
\hline TOTAL & 10 & 228 & 38 & 7 & 2 & 0 & 285 \\
\hline
\end{tabular}


APÊNDICE 9 - Número de comportamentos não-verbais indicativos de comunicação emitidos pelas crianças nos focais finais (13/10/04 a

16/11/04) de A, C, Gi, H, La e S.

\begin{tabular}{|c|c|c|c|c|c|c|c|}
\hline Não-verbal emitido / Referência & Própria criança & Outra(s) criança(s) & Educadora & Pesquisadora & Referência desconhecida & Pessoa ausente & TOTAL \\
\hline Olhares & $\begin{array}{c}\mathbf{0} \\
\end{array}$ & 49 & \begin{tabular}{|l|}
4 \\
\end{tabular} & \begin{tabular}{|c|}
8 \\
\end{tabular} & 0 & $\mathbf{0}$ & 61 \\
\hline Olhar/observar & 0 & 42 & 4 & 8 & 0 & 0 & 54 \\
\hline Olhar recíproco & 0 & 7 & 0 & 0 & 0 & 0 & 7 \\
\hline Contatos amistosos & $\mathbf{0}$ & 2 & $\mathbf{0}$ & 4 & $\mathbf{0}$ & $\mathbf{0}$ & 6 \\
\hline Contato corporal & 0 & 1 & 0 & 4 & 0 & 0 & 5 \\
\hline Acariciar & 0 & 1 & 0 & 0 & 0 & 0 & 1 \\
\hline Abraçar, beijar & 0 & 0 & 0 & 0 & 0 & 0 & 0 \\
\hline Dar a mão para & 0 & 0 & 0 & 0 & 0 & 0 & 0 \\
\hline Puxar a mão do outro & 0 & 0 & 0 & 0 & 0 & 0 & 0 \\
\hline Expressões corporais & 1 & 14 & $\mathbf{0}$ & $\mathbf{0}$ & $\mathbf{0}$ & $\mathbf{0}$ & 15 \\
\hline Movimento do corpo & 0 & 2 & 0 & 0 & 0 & 0 & 2 \\
\hline Expressão corporal de braveza & 0 & 2 & 0 & 0 & 0 & 0 & 2 \\
\hline Virar o corpo de frente para & 0 & 7 & 0 & 0 & 0 & 0 & 7 \\
\hline Virar o corpo de costas para & 0 & 0 & 0 & 0 & 0 & 0 & 0 \\
\hline Separar briga entre duas crianças & 0 & 0 & 0 & 0 & 0 & 0 & 0 \\
\hline Expressões corporais de excitação & 0 & 0 & 0 & 0 & 0 & 0 & 0 \\
\hline Bater palmas & 1 & 3 & 0 & 0 & 0 & 0 & 4 \\
\hline Gestos e acenos & $\mathbf{0}$ & 23 & 2 & $\mathbf{0}$ & $\mathbf{0}$ & $\mathbf{0}$ & 25 \\
\hline Balançar vertical da cabeça ("sim") & 0 & 0 & 0 & 0 & 0 & 0 & 0 \\
\hline Balançar horizontal da cabeça ("não") & 0 & 1 & 0 & 0 & 0 & 0 & 1 \\
\hline Estender o braço (pedido) & 0 & 1 & 0 & 0 & 0 & 0 & 1 \\
\hline Estender objeto para & 0 & 12 & 2 & 0 & 0 & 0 & 14 \\
\hline Segurar e mostrar um objeto & 0 & 2 & 0 & 0 & 0 & 0 & 2 \\
\hline Apontar & 0 & 1 & 0 & 0 & 0 & 0 & 1 \\
\hline Aceno de despedida & 0 & 0 & 0 & 0 & 0 & 0 & 0 \\
\hline Sinal de "não" com o dedo indicador & 0 & 0 & 0 & 0 & 0 & 0 & 0 \\
\hline Abrir a boca (pedindo comida) & 0 & 0 & 0 & 0 & 0 & 0 & 0 \\
\hline $\begin{array}{l}\text { Levantar os braços para o alto } \\
\text { (comemorar) }\end{array}$ & 0 & 2 & 0 & 0 & 0 & 0 & 2 \\
\hline
\end{tabular}




\begin{tabular}{|c|c|c|c|c|c|c|c|}
\hline Não-verbal emitido / Referência & Própria criança & Outra(s) criança(s) & Educadora & Pesquisadora & Referência desconhecida & Pessoa ausente & TOTAL \\
\hline Fazer gesto para sentar & 0 & 0 & \begin{tabular}{|c|}
0 \\
\end{tabular} & \begin{tabular}{|c|}
0 \\
\end{tabular} & \begin{tabular}{|c|}
0 \\
\end{tabular} & 0 & 0 \\
\hline Gesto de chamar & 0 & 1 & 0 & 0 & 0 & 0 & 1 \\
\hline Gesto de interrogação/dúvida & 0 & 0 & 0 & 0 & 0 & 0 & 0 \\
\hline Gesto de confusão & 0 & 1 & 0 & 0 & 0 & 0 & 1 \\
\hline Gesto de ameaça ou de assustar & 0 & 0 & 0 & 0 & 0 & 0 & 0 \\
\hline Gesto de beber ou comer & 0 & 0 & 0 & 0 & 0 & 0 & 0 \\
\hline Gesto indefinido, atípico & 0 & 2 & 0 & 0 & 0 & 0 & 2 \\
\hline Comportamentos agonísticos & $\mathbf{0}$ & 24 & $\mathbf{0}$ & $\mathbf{0}$ & $\mathbf{0}$ & $\mathbf{0}$ & 24 \\
\hline Agonismo & 0 & 15 & 0 & 0 & 0 & 0 & 15 \\
\hline Bater de brincadeira (turbulenta) & 0 & 9 & 0 & 0 & 0 & 0 & 9 \\
\hline Expressões faciais & 2 & 40 & 2 & 4 & 2 & $\mathbf{0}$ & 50 \\
\hline Sorriso & 0 & 18 & 0 & 1 & 1 & 0 & 20 \\
\hline Riso & 1 & 19 & 0 & 3 & 0 & 0 & 23 \\
\hline Choro, choramingo & 1 & 1 & 0 & 0 & 1 & 0 & 3 \\
\hline Expressão facial específica & 0 & 2 & 2 & 0 & 0 & 0 & 4 \\
\hline Vocalizações & 3 & 17 & $\mathbf{0}$ & $\mathbf{0}$ & $\mathbf{0}$ & $\mathbf{0}$ & 20 \\
\hline Vocalização & 3 & 17 & 0 & 0 & 0 & 0 & 20 \\
\hline Vocalização alternada & 0 & 0 & 0 & 0 & 0 & 0 & 0 \\
\hline Imitação & $\mathbf{0}$ & 29 & $\mathbf{0}$ & $\mathbf{0}$ & $\mathbf{0}$ & $\mathbf{0}$ & 29 \\
\hline Imitação & 0 & 29 & 0 & 0 & 0 & 0 & 29 \\
\hline TOTAL & 6 & 198 & 8 & 16 & 2 & 0 & 230 \\
\hline
\end{tabular}


APÊNDICE 10 - Número de episódios de verbalizações emitidas pelas crianças nos focais iniciais (21/8/03 a 22/9/03) de A, C, Gi, H,

\section{La e S.}

\begin{tabular}{|c|c|c|c|c|c|c|c|c|c|}
\hline Contexto/referência & \begin{tabular}{|l|} 
Própria \\
criança
\end{tabular} & $\begin{array}{l}\text { Outra(s) } \\
\text { criança(s) }\end{array}$ & \begin{tabular}{|l|} 
Objeto com \\
o qual está
\end{tabular} & $\begin{array}{l}\text { Objeto que está com } \\
\text { outra criança }\end{array}$ & $\begin{array}{l}\text { Objeto no } \\
\text { espaço }\end{array}$ & Educadora & Pesquisadora & \begin{tabular}{|l|} 
Referência \\
desconhecida
\end{tabular} & \begin{tabular}{|l|} 
Pessoa \\
ausente \\
\end{tabular} \\
\hline Imperativos & 0 & 10 & $\mathbf{0}$ & 0 & 0 & 1 & $\mathbf{0}$ & 0 & $\mathbf{0}$ \\
\hline Repreender (relativo a regras) & 0 & 1 & 0 & 0 & 0 & 0 & 0 & 0 & 0 \\
\hline Impedir/parar ação & 0 & 9 & 0 & 0 & 0 & 1 & 0 & 0 & 0 \\
\hline Dar ordem (para) & 0 & 0 & 0 & 0 & 0 & 0 & 0 & 0 & 0 \\
\hline Afirmações informativas & 3 & 3 & $\mathbf{0}$ & $\mathbf{0}$ & $\mathbf{0}$ & 1 & $\mathbf{0}$ & $\mathbf{0}$ & $\mathbf{0}$ \\
\hline Descrever ação/situação (de) & 3 & 1 & 0 & 0 & 0 & 0 & 0 & 0 & 0 \\
\hline Mostrar (para) & 0 & 1 & 0 & 0 & 0 & 1 & 0 & 0 & 0 \\
\hline Expressar sentimentos (para) & 0 & 1 & 0 & 0 & 0 & 0 & 0 & 0 & 0 \\
\hline Afirmações designativas & $\mathbf{1}$ & $\mathbf{0}$ & $\mathbf{0}$ & $\mathbf{0}$ & $\mathbf{0}$ & $\mathbf{0}$ & $\mathbf{0}$ & $\mathbf{0}$ & $\mathbf{0}$ \\
\hline Indicar quem possui & 1 & 0 & 0 & 0 & 0 & 0 & 0 & 0 & 0 \\
\hline Atribuir papel/função (para) & 0 & 0 & 0 & 0 & 0 & 0 & 0 & 0 & 0 \\
\hline Questões diretivas & $\mathbf{0}$ & 2 & $\mathbf{0}$ & $\mathbf{0}$ & $\mathbf{0}$ & $\mathbf{0}$ & 1 & $\mathbf{0}$ & $\mathbf{0}$ \\
\hline Pedir (para alguém) & 0 & 2 & 0 & 0 & 0 & 0 & 1 & 0 & 0 \\
\hline Convites para interação & $\mathbf{0}$ & 4 & $\mathbf{0}$ & $\mathbf{0}$ & $\mathbf{0}$ & 1 & $\mathbf{0}$ & $\mathbf{0}$ & $\mathbf{0}$ \\
\hline Convidar para sentar & 0 & 2 & 0 & 0 & 0 & 0 & 0 & 0 & 0 \\
\hline Convidar(-se) para brincar/jogar & 0 & 1 & 0 & 0 & 0 & 0 & 0 & 0 & 0 \\
\hline Oferecer (objeto para) & 0 & 1 & 0 & 0 & 0 & 1 & 0 & 0 & 0 \\
\hline Respostas & $\mathbf{0}$ & $\mathbf{0}$ & $\mathbf{0}$ & $\mathbf{0}$ & $\mathbf{0}$ & $\mathbf{0}$ & $\mathbf{0}$ & $\mathbf{0}$ & 1 \\
\hline Responder pergunta (de) & 0 & 0 & 0 & 0 & 0 & 0 & 0 & 0 & 1 \\
\hline Concordar com/confirmar & 0 & 0 & 0 & 0 & 0 & 0 & 0 & 0 & 0 \\
\hline Discordar de/negar & 0 & 0 & 0 & 0 & 0 & 0 & 0 & 0 & 0 \\
\hline Pedidos de informação & $\mathbf{0}$ & 2 & $\mathbf{0}$ & $\mathbf{0}$ & $\mathbf{0}$ & $\mathbf{0}$ & $\mathbf{0}$ & $\mathbf{0}$ & 1 \\
\hline Perguntar (para) & 0 & 2 & 0 & 0 & 0 & 0 & 0 & 0 & 0 \\
\hline Procurar (perguntar para) & 0 & 0 & 0 & 0 & 0 & 0 & 0 & 0 & 1 \\
\hline Falas nominativas & 2 & $\mathbf{0}$ & 1 & $\mathbf{0}$ & $\mathbf{0}$ & 2 & $\mathbf{0}$ & $\mathbf{0}$ & $\mathbf{0}$ \\
\hline Chamar (pelo nome) & 0 & 0 & 0 & 0 & 0 & 2 & 0 & 0 & 0 \\
\hline Falar o nome ou apelido (de) & 2 & 0 & 1 & 0 & 0 & 0 & 0 & 0 & 0 \\
\hline
\end{tabular}




\begin{tabular}{|c|c|c|c|c|c|c|c|c|c|}
\hline Contexto/referência & $\begin{array}{l}\text { Própria } \\
\text { criança }\end{array}$ & $\begin{array}{l}\text { Outra(s) } \\
\text { criança(s) }\end{array}$ & $\begin{array}{l}\text { Objeto com } \\
\text { o qual está }\end{array}$ & $\begin{array}{l}\text { Objeto que está com } \\
\text { outra criança }\end{array}$ & $\begin{array}{l}\text { Objeto no } \\
\text { espaço }\end{array}$ & Educadora & Pesquisadora & $\begin{array}{l}\text { Referência } \\
\text { desconhecida }\end{array}$ & $\begin{array}{l}\text { Pessoa } \\
\text { ausente }\end{array}$ \\
\hline Agonismo & $\mathbf{0}$ & 13 & $\mathbf{0}$ & $\mathbf{0}$ & $\mathbf{0}$ & 1 & $\mathbf{0}$ & $\mathbf{0}$ & $\mathbf{0}$ \\
\hline Disputar (objeto com alguém) & 0 & 4 & 0 & 0 & 0 & 0 & 0 & 0 & 0 \\
\hline Afastar (alguém) & 0 & 4 & 0 & 0 & 0 & 1 & 0 & 0 & 0 \\
\hline Defender colega & 0 & 2 & 0 & 0 & 0 & 0 & 0 & 0 & 0 \\
\hline Agredir & 0 & 3 & 0 & 0 & 0 & 0 & 0 & 0 & 0 \\
\hline Reagir a bronca de educadora & 0 & 0 & 0 & 0 & 0 & 0 & 0 & 0 & 0 \\
\hline Narrativas & $\mathbf{0}$ & $\mathbf{0}$ & $\mathbf{0}$ & $\mathbf{0}$ & $\mathbf{0}$ & $\mathbf{0}$ & $\mathbf{0}$ & 1 & $\mathbf{0}$ \\
\hline Contar história (para) & 0 & 0 & 0 & 0 & 0 & 0 & 0 & 0 & 0 \\
\hline Cantar (para) & 0 & 0 & 0 & 0 & 0 & 0 & 0 & 1 & 0 \\
\hline Cumprimentos & $\mathbf{0}$ & 4 & $\mathbf{0}$ & $\mathbf{0}$ & $\mathbf{0}$ & $\mathbf{0}$ & $\mathbf{0}$ & 1 & $\mathbf{0}$ \\
\hline Cumprimentar & 0 & 4 & 0 & 0 & 0 & 0 & 0 & 1 & 0 \\
\hline Agradecimentos & $\mathbf{0}$ & $\mathbf{0}$ & $\mathbf{0}$ & $\mathbf{0}$ & $\mathbf{0}$ & $\mathbf{0}$ & $\mathbf{0}$ & $\mathbf{0}$ & $\mathbf{0}$ \\
\hline Agradecer & 0 & 0 & 0 & 0 & 0 & 0 & 0 & 0 & 0 \\
\hline Elogios & $\mathbf{0}$ & $\mathbf{0}$ & $\mathbf{0}$ & $\mathbf{0}$ & 1 & $\mathbf{0}$ & $\mathbf{0}$ & $\mathbf{0}$ & $\mathbf{0}$ \\
\hline Elogiar & 0 & 0 & 0 & 0 & 1 & 0 & 0 & 0 & 0 \\
\hline Falas ininteligíveis & $\mathbf{0}$ & 5 & $\mathbf{0}$ & $\mathbf{0}$ & 1 & $\mathbf{0}$ & $\mathbf{0}$ & 2 & $\mathbf{0}$ \\
\hline
\end{tabular}


APÊNDICE 11 - Número de episódios de verbalizações emitidas pelas crianças nos focais intermediários (25/3/04 a 28/4/04) de A, C, Gi,

H, La e S.

\begin{tabular}{|c|c|c|c|c|c|c|c|c|c|}
\hline Contexto/referência & $\begin{array}{l}\text { Própria } \\
\text { criança }\end{array}$ & $\begin{array}{l}\text { Outra(s) } \\
\text { criança(s) }\end{array}$ & $\begin{array}{l}\text { Objeto com o } \\
\text { qual está } \\
\end{array}$ & $\begin{array}{l}\text { Objeto que está } \\
\text { com outra criança }\end{array}$ & $\begin{array}{l}\text { Objeto no } \\
\text { espaço }\end{array}$ & Educadora & Pesquisadora & $\begin{array}{l}\text { Referência } \\
\text { desconhecida }\end{array}$ & \begin{tabular}{|l|} 
Pessoa \\
ausente
\end{tabular} \\
\hline Imperativos & \begin{tabular}{|c|}
$\mathbf{0}$ \\
\end{tabular} & 6 & 2 & $\mathbf{0}$ & $\mathbf{0}$ & 3 & $\mathbf{0}$ & $\begin{array}{c}0 \\
\end{array}$ & \begin{tabular}{|l|}
$\mathbf{0}$ \\
\end{tabular} \\
\hline Repreender (relativo a regras) & 0 & 0 & 0 & 0 & 0 & 2 & 0 & 0 & 0 \\
\hline Impedir/parar ação & 0 & 1 & 0 & 0 & 0 & 0 & 0 & 0 & 0 \\
\hline Dar ordem (para) & 0 & 5 & 2 & 0 & 0 & 1 & 0 & 0 & 0 \\
\hline Afirmações informativas & 6 & 2 & 6 & 1 & $\mathbf{0}$ & 3 & $\mathbf{0}$ & $\mathbf{0}$ & $\mathbf{0}$ \\
\hline Descrever ação/situação (de) & 6 & 0 & 6 & 1 & 0 & 0 & 0 & 0 & 0 \\
\hline Mostrar (para) & 0 & 2 & 0 & 0 & 0 & 3 & 0 & 0 & 0 \\
\hline Expressar sentimentos (para) & 0 & 0 & 0 & 0 & 0 & 0 & 0 & 0 & 0 \\
\hline Afirmações designativas & 1 & $\mathbf{0}$ & 1 & 2 & 2 & $\mathbf{0}$ & $\mathbf{0}$ & $\mathbf{0}$ & $\mathbf{0}$ \\
\hline Indicar quem possui & 1 & 0 & 0 & 1 & 1 & 0 & 0 & 0 & 0 \\
\hline Atribuir papel/função (para) & 0 & 0 & 1 & 1 & 1 & 0 & 0 & 0 & 0 \\
\hline Questões diretivas & $\mathbf{0}$ & $\mathbf{0}$ & $\mathbf{0}$ & $\mathbf{0}$ & $\mathbf{0}$ & 5 & $\mathbf{0}$ & $\mathbf{0}$ & $\mathbf{0}$ \\
\hline Pedir (para alguém) & 0 & 0 & 0 & 0 & 0 & 5 & 0 & 0 & 0 \\
\hline Convites para interação & 2 & 5 & 2 & 2 & $\mathbf{0}$ & 5 & $\mathbf{0}$ & $\mathbf{0}$ & $\mathbf{0}$ \\
\hline Convidar para sentar & 0 & 0 & 0 & 0 & 0 & 0 & 0 & 0 & 0 \\
\hline $\begin{array}{l}\text { Convidar(-se) para } \\
\text { brincar/jogar }\end{array}$ & 2 & 1 & 0 & 0 & 0 & 0 & 0 & 0 & 0 \\
\hline Oferecer (objeto para) & 0 & 4 & 2 & 2 & 0 & 5 & 0 & 0 & 0 \\
\hline Respostas & $\mathbf{0}$ & 2 & $\mathbf{0}$ & $\mathbf{0}$ & $\mathbf{0}$ & 7 & $\mathbf{0}$ & $\mathbf{0}$ & $\mathbf{0}$ \\
\hline Responder pergunta (de) & 0 & 0 & 0 & 0 & 0 & 3 & 0 & 0 & 0 \\
\hline Concordar com/confirmar & 0 & 0 & 0 & 0 & 0 & 3 & 0 & 0 & 0 \\
\hline Discordar de/negar & 0 & 2 & 0 & 0 & 0 & 1 & 0 & 0 & 0 \\
\hline Pedidos de informação & $\mathbf{0}$ & 3 & $\mathbf{0}$ & $\mathbf{0}$ & $\mathbf{0}$ & 1 & $\mathbf{0}$ & 1 & $\mathbf{0}$ \\
\hline Perguntar (para) & 0 & 2 & 0 & 0 & 0 & 0 & 0 & 0 & 0 \\
\hline Procurar (perguntar para) & 0 & 1 & 0 & 0 & 0 & 1 & 0 & 1 & 0 \\
\hline Falas nominativas & $\mathbf{0}$ & 7 & 2 & $\mathbf{0}$ & 1 & $\mathbf{0}$ & $\mathbf{0}$ & $\mathbf{0}$ & $\mathbf{0}$ \\
\hline Chamar (pelo nome) & 0 & 5 & 0 & 0 & 0 & 0 & 0 & 0 & 0 \\
\hline Falar o nome ou apelido (de) & 0 & 2 & 2 & 0 & 1 & 0 & 0 & 0 & 0 \\
\hline Agonismo & $\mathbf{0}$ & 6 & $\mathbf{0}$ & $\mathbf{0}$ & $\mathbf{0}$ & 1 & $\mathbf{0}$ & $\mathbf{0}$ & $\mathbf{0}$ \\
\hline
\end{tabular}




\begin{tabular}{|c|c|c|c|c|c|c|c|c|c|}
\hline Contexto/referência & $\begin{array}{l}\text { Própria } \\
\text { criança }\end{array}$ & $\begin{array}{l}\text { Outra(s) } \\
\text { criança(s) }\end{array}$ & $\begin{array}{l}\text { Objeto com o } \\
\text { qual está } \\
\end{array}$ & \begin{tabular}{|l|} 
Objeto que está \\
com outra criança
\end{tabular} & \begin{tabular}{|l|}
$\begin{array}{l}\text { Objeto no } \\
\text { espaço }\end{array}$ \\
\end{tabular} & Educadora & Pesquisadora & \begin{tabular}{|l|}
$\begin{array}{l}\text { Referência } \\
\text { desconhecida }\end{array}$ \\
\end{tabular} & \begin{tabular}{|l|}
$\begin{array}{l}\text { Pessoa } \\
\text { ausente }\end{array}$ \\
\end{tabular} \\
\hline Disputar (objeto com alguém) & 0 & 4 & 0 & 0 & 0 & 0 & 0 & 0 & 0 \\
\hline Afastar (alguém) & 0 & 2 & 0 & 0 & 0 & 0 & 0 & 0 & 0 \\
\hline Defender colega & 0 & 0 & 0 & 0 & 0 & 0 & 0 & 0 & 0 \\
\hline Agredir & 0 & 0 & 0 & 0 & 0 & 0 & 0 & 0 & 0 \\
\hline Reagir a bronca de educadora & 0 & 0 & 0 & 0 & 0 & 1 & 0 & 0 & 0 \\
\hline Narrativas & $\mathbf{0}$ & $\mathbf{0}$ & 5 & $\mathbf{0}$ & $\mathbf{0}$ & $\mathbf{0}$ & $\mathbf{0}$ & $\mathbf{0}$ & $\mathbf{0}$ \\
\hline Contar história (para) & 0 & 0 & 0 & 0 & 0 & 0 & 0 & 0 & 0 \\
\hline Cantar (para) & 0 & 0 & 5 & 0 & 0 & 0 & 0 & 0 & 0 \\
\hline Cumprimentos & $\mathbf{0}$ & 4 & $\mathbf{0}$ & $\mathbf{0}$ & $\mathbf{0}$ & $\mathbf{0}$ & $\mathbf{0}$ & 1 & $\mathbf{0}$ \\
\hline Cumprimentar & 0 & 4 & 0 & 0 & 0 & 0 & 0 & 1 & 0 \\
\hline Agradecimentos & $\mathbf{0}$ & $\mathbf{0}$ & $\mathbf{0}$ & $\mathbf{0}$ & $\mathbf{0}$ & $\mathbf{0}$ & $\mathbf{0}$ & $\mathbf{0}$ & $\mathbf{0}$ \\
\hline Agradecer & 0 & 0 & 0 & 0 & 0 & 0 & 0 & 0 & 0 \\
\hline Elogios & $\mathbf{0}$ & $\mathbf{0}$ & $\mathbf{0}$ & $\mathbf{0}$ & $\mathbf{0}$ & $\mathbf{0}$ & $\mathbf{0}$ & 1 & $\mathbf{0}$ \\
\hline Elogiar & 0 & 0 & 0 & 0 & 0 & 0 & 0 & 1 & 0 \\
\hline Falas ininteligíveis & $\mathbf{0}$ & 17 & 4 & 2 & $\mathbf{0}$ & 2 & 2 & 9 & 0 \\
\hline
\end{tabular}


APÊNDICE 12 - Número de episódios de verbalizações emitidas pelas crianças nos focais finais (13/10/04 a 16/11/04) de A, C, Gi, H,

La e $S$.

\begin{tabular}{|c|c|c|c|c|c|c|c|c|c|}
\hline Contexto/referência & $\begin{array}{l}\text { Própria } \\
\text { criança }\end{array}$ & $\begin{array}{l}\text { Outra(s) } \\
\text { criança(s) }\end{array}$ & $\begin{array}{l}\text { Objeto com o } \\
\text { qual está }\end{array}$ & $\begin{array}{l}\text { Objeto que está } \\
\text { com outra criança }\end{array}$ & $\begin{array}{l}\text { Objeto no } \\
\text { espaço }\end{array}$ & Educadora & Pesquisadora & $\begin{array}{l}\text { Referência } \\
\text { desconhecida }\end{array}$ & $\begin{array}{l}\text { Pessoa } \\
\text { ausente }\end{array}$ \\
\hline Imperativos & $\mathbf{0}$ & 5 & $\mathbf{0}$ & $\mathbf{0}$ & $\mathbf{0}$ & 2 & $\mathbf{0}$ & \begin{tabular}{|c|}
$\mathbf{0}$ \\
\end{tabular} & $\begin{array}{l}\mathbf{0} \\
\end{array}$ \\
\hline Repreender (relativo a regras) & 0 & 1 & 0 & 0 & 0 & 0 & 0 & 0 & 0 \\
\hline Impedir/parar ação & 0 & 1 & 0 & 0 & 0 & 0 & 0 & 0 & 0 \\
\hline Dar ordem (para) & 0 & 3 & 0 & 0 & 0 & 2 & 0 & 0 & 0 \\
\hline Afirmações informativas & 7 & 3 & 6 & $\mathbf{0}$ & $\mathbf{0}$ & $\mathbf{0}$ & $\mathbf{0}$ & $\mathbf{0}$ & $\mathbf{0}$ \\
\hline Descrever ação/situação (de) & 7 & 0 & 6 & 0 & 0 & 0 & 0 & 0 & 0 \\
\hline Mostrar (para) & 0 & 3 & 0 & 0 & 0 & 0 & 0 & 0 & 0 \\
\hline Expressar sentimentos (para) & 0 & 0 & 0 & 0 & 0 & 0 & 0 & 0 & 0 \\
\hline Afirmações designativas & 2 & 2 & 3 & $\mathbf{0}$ & $\mathbf{0}$ & $\mathbf{0}$ & $\mathbf{0}$ & 1 & $\mathbf{0}$ \\
\hline Indicar quem possui & 0 & 1 & 0 & 0 & 0 & 0 & 0 & 0 & 0 \\
\hline Atribuir papel/função (para) & 2 & 1 & 3 & 0 & 0 & 0 & 0 & 1 & 0 \\
\hline Questões diretivas & $\mathbf{0}$ & $\mathbf{1 0}$ & $\mathbf{0}$ & $\mathbf{0}$ & $\mathbf{0}$ & 1 & $\mathbf{0}$ & $\mathbf{0}$ & $\mathbf{0}$ \\
\hline Pedir (para alguém) & 0 & 10 & 0 & 0 & 0 & 1 & 0 & 0 & 0 \\
\hline Convites para interação & 1 & 31 & $\mathbf{0}$ & $\mathbf{0}$ & $\mathbf{0}$ & 3 & $\mathbf{0}$ & $\mathbf{0}$ & $\mathbf{0}$ \\
\hline Convidar para sentar & 0 & 0 & 0 & 0 & 0 & 0 & 0 & 0 & 0 \\
\hline Convidar(-se) para brincar/jogar & 1 & 4 & 0 & 0 & 0 & 0 & 0 & 0 & 0 \\
\hline Oferecer (objeto para) & 0 & 27 & 0 & 0 & 0 & 3 & 0 & 0 & 0 \\
\hline Respostas & $\mathbf{0}$ & 11 & $\mathbf{0}$ & $\mathbf{0}$ & $\mathbf{0}$ & $\mathbf{0}$ & $\mathbf{0}$ & $\mathbf{0}$ & $\mathbf{0}$ \\
\hline Responder pergunta (de) & 0 & 4 & 0 & 0 & 0 & 0 & 0 & 0 & 0 \\
\hline Concordar com/confirmar & 0 & 3 & 0 & 0 & 0 & 0 & 0 & 0 & 0 \\
\hline Discordar de/negar & 0 & 4 & 0 & 0 & 0 & 0 & 0 & 0 & 0 \\
\hline Pedidos de informação & $\mathbf{0}$ & 3 & $\mathbf{0}$ & $\mathbf{0}$ & $\mathbf{0}$ & $\mathbf{0}$ & $\mathbf{0}$ & 2 & $\mathbf{0}$ \\
\hline Perguntar (para) & 0 & 1 & 0 & 0 & 0 & 0 & 0 & 0 & 0 \\
\hline Procurar (perguntar para) & 0 & 2 & 0 & 0 & 0 & 0 & 0 & 2 & 0 \\
\hline Falas nominativas & 1 & 2 & 3 & $\mathbf{0}$ & $\mathbf{0}$ & $\mathbf{0}$ & $\mathbf{0}$ & $\mathbf{0}$ & $\mathbf{0}$ \\
\hline Chamar (pelo nome) & 1 & 2 & 0 & 0 & 0 & 0 & 0 & 0 & 0 \\
\hline Falar o nome ou apelido (de) & 0 & 0 & 3 & 0 & 0 & 0 & 0 & 0 & 0 \\
\hline
\end{tabular}




\begin{tabular}{|c|c|c|c|c|c|c|c|c|c|}
\hline Contexto/referência & \begin{tabular}{|l|} 
Própria \\
criança
\end{tabular} & $\begin{array}{l}\text { Outra(s) } \\
\text { criança(s) }\end{array}$ & $\begin{array}{l}\text { Objeto com o } \\
\text { qual está }\end{array}$ & $\begin{array}{l}\text { Objeto que está } \\
\text { com outra criança }\end{array}$ & $\begin{array}{l}\text { Objeto no } \\
\text { espaço }\end{array}$ & Educadora & Pesquisadora & $\begin{array}{l}\text { Referência } \\
\text { desconhecida }\end{array}$ & $\begin{array}{l}\text { Pessoa } \\
\text { ausente }\end{array}$ \\
\hline Agonismo & $\mathbf{0}$ & 7 & $\mathbf{0}$ & $\mathbf{0}$ & 0 & $\mathbf{0}$ & $\mathbf{0}$ & $\mathbf{0}$ & 0 \\
\hline Disputar (objeto com alguém) & 0 & 3 & 0 & 0 & 0 & 0 & 0 & 0 & 0 \\
\hline Afastar (alguém) & 0 & 3 & 0 & 0 & 0 & 0 & 0 & 0 & 0 \\
\hline Defender colega & 0 & 0 & 0 & 0 & 0 & 0 & 0 & 0 & 0 \\
\hline Agredir & 0 & 1 & 0 & 0 & 0 & 0 & 0 & 0 & 0 \\
\hline Reagir a bronca de educadora & 0 & 0 & 0 & 0 & 0 & 0 & 0 & 0 & 0 \\
\hline Narrativas & 2 & 5 & 4 & $\mathbf{0}$ & $\mathbf{0}$ & $\mathbf{0}$ & $\mathbf{0}$ & $\mathbf{0}$ & $\mathbf{0}$ \\
\hline Contar história (para) & 1 & 5 & 0 & 0 & 0 & 0 & 0 & 0 & 0 \\
\hline Cantar (para) & 1 & 0 & 4 & 0 & 0 & 0 & 0 & 0 & 0 \\
\hline Cumprimentos & $\mathbf{0}$ & 2 & $\mathbf{0}$ & $\mathbf{0}$ & $\mathbf{0}$ & $\mathbf{0}$ & $\mathbf{0}$ & $\mathbf{0}$ & $\mathbf{0}$ \\
\hline Cumprimentar & 0 & 2 & 0 & 0 & 0 & 0 & 0 & 0 & 0 \\
\hline Agradecimentos & $\mathbf{0}$ & 1 & $\mathbf{0}$ & $\mathbf{0}$ & $\mathbf{0}$ & $\mathbf{0}$ & $\mathbf{0}$ & $\mathbf{0}$ & $\mathbf{0}$ \\
\hline Agradecer & 0 & 1 & 0 & 0 & 0 & 0 & 0 & 0 & 0 \\
\hline Elogios & $\mathbf{0}$ & $\mathbf{0}$ & 1 & $\mathbf{0}$ & $\mathbf{0}$ & $\mathbf{0}$ & $\mathbf{0}$ & $\mathbf{0}$ & $\mathbf{0}$ \\
\hline Elogiar & 0 & 0 & 1 & 0 & 0 & 0 & 0 & 0 & 0 \\
\hline Falas ininteligíveis & $\mathbf{0}$ & 6 & $\mathbf{0}$ & $\mathbf{0}$ & $\mathbf{0}$ & 2 & $\mathbf{0}$ & 1 & $\mathbf{0}$ \\
\hline
\end{tabular}


APÊNDICE 13 - Comparação entre o número de episódios de verbalizações emitidas pelas crianças nos focais iniciais (21/8/03 a 22/9/03), intermediários (25/3/04 a 28/4/04) e finais (13/10/04 a 16/11/04), de A, C, Gi, H, La e S.

A) Quanto ao contexto

\begin{tabular}{|c|c|c|c|c|}
\hline Contexto/focais & Focais iniciais & Focais intermediários & Focais finais & Total (soma) \\
\hline Imperativos & 11 & 11 & 7 & 29 \\
\hline Repreender (relativo a regras) & 1 & 2 & 1 & 4 \\
\hline Impedir/parar ação & 10 & 1 & 1 & 12 \\
\hline Dar ordem (para) & 0 & 8 & 5 & 13 \\
\hline Afirmações informativas & 7 & 18 & 16 & 41 \\
\hline Descrever ação/situação (de) & 4 & 13 & 13 & 30 \\
\hline Mostrar (para) & 2 & 5 & 3 & 10 \\
\hline Expressar sentimentos (para) & 1 & 0 & 0 & 1 \\
\hline Afirmações designativas & 1 & 6 & 8 & 15 \\
\hline Indicar quem possui & 1 & 3 & 1 & 5 \\
\hline Atribuir papel/função (para) & 0 & 3 & 7 & 10 \\
\hline Questões diretivas & 3 & 5 & 11 & 19 \\
\hline Pedir (para alguém) & 3 & 5 & 11 & 19 \\
\hline Convites para interação & 5 & 16 & 35 & 56 \\
\hline Convidar para sentar & 2 & 0 & 0 & 2 \\
\hline Convidar(-se) para brincar/jogar & 1 & 3 & 5 & 9 \\
\hline Oferecer (objeto para) & 2 & 13 & 30 & 45 \\
\hline Respostas & 1 & 9 & 11 & 21 \\
\hline Responder pergunta (de) & 1 & 3 & 4 & 8 \\
\hline Concordar com/confirmar & 0 & 3 & 3 & 6 \\
\hline Discordar de/negar & 0 & 3 & 4 & 7 \\
\hline Pedidos de informação & 3 & 5 & 5 & 13 \\
\hline Perguntar (para) & 2 & 2 & 1 & 5 \\
\hline Procurar (perguntar para) & 1 & 3 & 4 & 8 \\
\hline Falas nominativas & 5 & 10 & 6 & 21 \\
\hline Chamar (pelo nome) & 2 & 5 & 3 & 10 \\
\hline
\end{tabular}




\begin{tabular}{|c|c|c|c|c|}
\hline Contexto/focais & Focais iniciais & Focais intermediários & Focais finais & Total (soma) \\
\hline Falar o nome ou apelido (de) & 3 & 5 & 3 & 11 \\
\hline Agonismo & 14 & 7 & 7 & 28 \\
\hline Disputar (objeto com alguém) & 4 & 4 & 3 & 11 \\
\hline Afastar (alguém) & 5 & 2 & 3 & 10 \\
\hline Defender colega & 2 & 0 & 0 & 2 \\
\hline Agredir & 3 & 0 & 1 & 4 \\
\hline Reagir a bronca de educadora & 0 & 1 & 0 & 1 \\
\hline Narrativas & 1 & 5 & 11 & 17 \\
\hline Contar história (para) & 0 & 0 & 6 & 6 \\
\hline Cantar (para) & 1 & 5 & 5 & 11 \\
\hline Cumprimentos & 5 & 5 & 2 & 12 \\
\hline Cumprimentar & 5 & 5 & 2 & 12 \\
\hline Agradecimentos & $\mathbf{0}$ & $\mathbf{0}$ & 1 & 1 \\
\hline Agradecer & 0 & 0 & 1 & 1 \\
\hline Elogios & 1 & 1 & 1 & 3 \\
\hline Elogiar & 1 & 1 & 1 & 3 \\
\hline Falas ininteligíveis & 8 & 36 & 9 & 53 \\
\hline Total (episódios de verbalização) & 65 & 134 & 130 & 329 \\
\hline
\end{tabular}

\section{B) Quanto à referência}

\begin{tabular}{|c|c|c|c|c|c|c|c|c|c|}
\hline Focais/referência & $\begin{array}{l}\text { Própria } \\
\text { criança }\end{array}$ & $\begin{array}{l}\text { Outra(s) } \\
\text { criança(s) }\end{array}$ & \begin{tabular}{|l|} 
Objeto com \\
o qual está
\end{tabular} & $\begin{array}{l}\text { Objeto que está } \\
\text { com outra criança }\end{array}$ & Objeto no espaço & Educadora & Pesquisadora & $\begin{array}{l}\text { Referência } \\
\text { desconhecida }\end{array}$ & $\begin{array}{l}\text { Pessoa } \\
\text { ausente }\end{array}$ \\
\hline Iniciais & 6 & 43 & 1 & 0 & 2 & 6 & 1 & 4 & 2 \\
\hline Intermediários & 9 & 52 & 22 & 7 & 3 & 27 & 2 & 12 & 0 \\
\hline Finais & 13 & 88 & 17 & 0 & 0 & 8 & 0 & 4 & 0 \\
\hline Total & 28 & 183 & 40 & 7 & 5 & 41 & 3 & 20 & 2 \\
\hline
\end{tabular}




\section{APÊNDICE 14 - Categorias de objetos com os quais se observou as crianças brincando nas sessões de observação de atividade lúdica}

livre (focais do último semestre), número total de usos dos objetos ou brincadeiras de acordo com o sexo das crianças $\left(\mathbf{N}_{\mathrm{f}}=\right.$

feminino; $\mathbf{N}_{\mathrm{m}}=$ masculino), uso dos objetos conforme sua função usual (comum) ou diferente desta, e sujeitos-focais que foram observados brincando com os objetos $\left(S_{\mathrm{f}}=\right.$ feminino; $S_{m}=$ masculino).

\begin{tabular}{|c|c|c|c|c|c|c|c|c|}
\hline Categoria de objetos & $\mathbf{N}_{\mathbf{f}}$ & $\mathbf{N}_{\mathbf{m}}$ & Função igual à usual & $\mathbf{S}_{\mathbf{f}}$ & $\mathbf{S}_{\mathbf{m}}$ & Função diferente da usual & $\mathbf{S}_{\mathbf{f}}$ & $\mathbf{S}_{\mathrm{m}}$ \\
\hline \multirow{6}{*}{$\begin{array}{l}\text { Acessórios (bolsas, } \\
\text { mochilas, sacolas, } \\
\text { sapatos, chapéus) }\end{array}$} & \multirow{6}{*}{10} & \multirow{6}{*}{7} & Abrir e fechar (bolsa) & $\mathrm{A}(1)$ & & $\begin{array}{l}\text { Colocar bolsa (com bonequinho dentro) no assento de um } \\
\text { carrinho de bebê e empurrá-lo }\end{array}$ & Gi (2) & \\
\hline & & & Colocar objetos dentro (bolsa, sacola) & Gi (1) & $\mathrm{C}(1)$ & Colocar sacola sobre a própria cabeça & & $\mathrm{C}(1)$ \\
\hline & & & $\begin{array}{l}\text { "Vestir" (bolsas - no ombro, no pescoço, } \\
\text { no braço, na mão; sapatos - nos pés; } \\
\text { chapéus - na cabeça) }\end{array}$ & $\begin{array}{l}\text { Gi (2) } \\
\text { La (2) }\end{array}$ & $\mathrm{S}(1)$ & Movimentar bolsa (tipo nécessaire) no ar, segurando-a pela alça & & $\mathrm{S}(1)$ \\
\hline & & & $\begin{array}{l}\text { Colocar chapéu na cabeça de outras } \\
\text { crianças }\end{array}$ & Gi (1) & & Vestir uma mochila para frente, como avental, e passar roupa & $\mathrm{La}(1)$ & \\
\hline & & & $\begin{array}{l}\text { Brincar de médico com uma bolsa de } \\
\text { médico e uma boneca }\end{array}$ & & $\mathrm{H}(1)$ & & & \\
\hline & & & $\begin{array}{l}\text { Colocar objetos dentro da bolsa e ir } \\
\text { passear }\end{array}$ & & $\mathrm{S}(2)$ & & & \\
\hline \multirow{5}{*}{$\begin{array}{l}\text { Alimentos (fatias de } \\
\text { pizza de plástico) }\end{array}$} & \multirow{5}{*}{5} & \multirow{5}{*}{3} & $\begin{array}{l}\text { Tentar tirar um pedaço com o uso de um } \\
\text { garfo }\end{array}$ & & $\mathrm{Gu}(1)$ & Pisar sobre & & $\mathrm{Gu}(1)$ \\
\hline & & & Fingir que está comendo & $\begin{array}{l}\mathrm{B}(1) \\
\mathrm{Gi}(1)\end{array}$ & & $\begin{array}{l}\text { Ouvir música ou falar ao telefone (uma mão, segurando um garfo, } \\
\text { encostada numa orelha e um pedaço de pizza encostado à outra } \\
\text { orelha, na outra mão) }\end{array}$ & & $\mathrm{Gu}(1)$ \\
\hline & & & & & & $\begin{array}{l}\text { Fingir que está comendo e que o está molhando em água contida } \\
\text { numa panela e num pote de plástico. }\end{array}$ & Gi (1) & \\
\hline & & & Alimentar outra criança & Gi (1) & & & & \\
\hline & & & Comer e oferecer para outra criança & Gi (1) & & & & \\
\hline Almofada & 1 & 0 & & & & Movimentar a almofada em torno do próprio corpo e atirá-la & Gi (1) & \\
\hline \multirow{3}{*}{ Animais de plástico } & \multirow{3}{*}{1} & \multirow{3}{*}{2} & & & & Enfileirá-los lado a lado e contá-los & Gi (1) & \\
\hline & & & & & & Empilhar um animal sobre outro & & $\mathrm{S}(1)$ \\
\hline & & & & & & Montar sobre cavalinho (“pocotó”) & & $\mathrm{S}(1)$ \\
\hline Bichos de pelúcia & 1 & 0 & & & & $\begin{array}{l}\text { Oferecer para outra criança, primeiro como um bichinho mesmo, } \\
\text { depois o chamando de outros nomes (peixe, morango, chocolate) }\end{array}$ & $\mathrm{B}(1)$ & \\
\hline Bolas & 1 & 0 & Jogar bola com outra criança & $\mathrm{La}(1)$ & & & & \\
\hline
\end{tabular}




\begin{tabular}{|c|c|c|c|c|c|c|c|c|}
\hline Categoria de objetos & $\mathbf{N}_{\mathrm{f}}$ & $\mathbf{N}_{\mathbf{m}}$ & Função igual à usual & $\mathbf{S}_{\mathrm{f}}$ & $\mathbf{S}_{\mathrm{m}}$ & Função diferente da usual & $\mathbf{S}_{\mathrm{f}}$ & $\mathbf{S}_{\mathrm{m}}$ \\
\hline \multirow{13}{*}{ Bonecas } & \multirow{13}{*}{17} & \multirow{13}{*}{6} & $\begin{array}{l}\text { Colocá-la num carrinho de bebê e } \\
\text { empurrá-lo }\end{array}$ & A (1) & & Dançar com a boneca & Gi (1) & \\
\hline & & & Dar comida / bebida para a boneca & A (3) & $\mathrm{C}(1)$ & $\begin{array}{l}\text { Colocar uma boneca num carrinho e outra num segundo carrinho } \\
\text { e empurrá-los }\end{array}$ & & $\mathrm{H}(1)$ \\
\hline & & & Pentear / secar / cuidar cabelo da boneca & $\mathrm{A}(1)$ & $\mathrm{H}(1)$ & & & \\
\hline & & & Beijar e balançar uma boneca & & $\mathrm{Gu}(1)$ & & & \\
\hline & & & $\begin{array}{l}\text { Dar comida para a boneca e para si } \\
\text { próprio(a) }\end{array}$ & $\mathrm{La}(1)$ & & & & \\
\hline & & & Cuidar / tratar da boneca & $\begin{array}{l}\mathrm{A}(2) \\
\mathrm{La}(1)\end{array}$ & & & & \\
\hline & & & Mexer nos olhos e no rosto da boneca & & $\mathrm{Gu}(1)$ & & & \\
\hline & & & Carregá-la & & S (1) & & & \\
\hline & & & Niná-la & $\mathrm{B}(2)$ & & & & \\
\hline & & & $\begin{array}{l}\text { Colocar boneca sobre o colo, abraçá-la e } \\
\text { deitá-la sobre um pano estendido sobre a } \\
\text { mesa }\end{array}$ & $\operatorname{Li}(1)$ & & & & \\
\hline & & & $\begin{array}{l}\text { Secar cabelo de uma boneca, segurando } \\
\text { outra }\end{array}$ & $\mathrm{La}(1)$ & & & & \\
\hline & & & Falar com a boneca & $\mathrm{Gi}(2)$ & & & & \\
\hline & & & Cobrir boneca com panos & $\mathrm{B}(1)$ & & & & \\
\hline \multirow{2}{*}{$\begin{array}{l}\text { Bonequinhos de plástico } \\
\text { ("super-heróis") }\end{array}$} & \multirow[b]{2}{*}{1} & \multirow[b]{2}{*}{3} & $\begin{array}{l}\text { Movimentá-lo na frente de outra criança } \\
\text { e fazê-lo ficar em pé }\end{array}$ & & $\mathrm{S}(1)$ & Usar o bonequinho como arma de atirar & Gi (1) & \\
\hline & & & $\begin{array}{l}\text { Chamar o boneco de "hominho", abrir } \\
\text { suas pernas, fazê-lo andar sobre a mesa } \\
\text { e sentá-lo sobre ela }\end{array}$ & & $\mathrm{S}(1)$ & $\begin{array}{l}\text { Derrubar boneco, recolocá-lo em pé, pular, derrubá-lo, } \\
\text { movimentá-lo, derrubá-lo e recolocá-lo em pé }\end{array}$ & & $\mathrm{S}(1)$ \\
\hline $\begin{array}{l}\text { Brinquedo com } \\
\text { alavancas para atirar } \\
\text { bolinhas que ficam } \\
\text { dentro de uma cúpula }\end{array}$ & 0 & 3 & Apertar alavancas para atirar bolinhas & & $\begin{array}{l}\mathrm{C}(3) \\
\mathrm{H}(1) \\
\mathrm{S}(1)\end{array}$ & & & \\
\hline $\begin{array}{l}\text { Brinquedos com } \\
\text { orifícios e peças para } \\
\text { encaixar }\end{array}$ & 1 & 1 & Encaixar peças & A (1) & $\mathrm{Gu}(1)$ & & & \\
\hline \multirow{2}{*}{$\begin{array}{l}\text { Brinquedo que é uma } \\
\text { cesta de frutas (coloca-se } \\
\text { a colher dentro e "sai" } \\
\text { uma fruta - grudada na } \\
\text { colher) }\end{array}$} & \multirow[b]{2}{*}{2} & \multirow[b]{2}{*}{4} & $\begin{array}{l}\text { Mostrar para as outras crianças como o } \\
\text { brinquedo funciona }\end{array}$ & Gi (1) & & & & \\
\hline & & & “Tirar" frutas da cesta & $\mathrm{La}(1)$ & $\begin{array}{l}\mathrm{C}(1) \\
\mathrm{H}(3)\end{array}$ & & & \\
\hline
\end{tabular}




\begin{tabular}{|c|c|c|c|c|c|c|c|c|}
\hline Categoria de objetos & $\mathbf{N}_{\mathrm{f}}$ & $\mathbf{N}_{\mathrm{m}}$ & Função igual à usual & $\mathbf{S}_{\mathbf{f}}$ & $\mathbf{S}_{\mathrm{m}}$ & Função diferente da usual & $\mathbf{S}_{\mathbf{f}}$ & $\mathbf{S}_{\mathbf{m}}$ \\
\hline $\begin{array}{l}\text { Cadeirinha de plástico } \\
\text { para boneca }\end{array}$ & 0 & 1 & & & & Desmontar & & $\mathrm{C}(1)$ \\
\hline Cadernos & 4 & 4 & Desenhar & A (3) & $\begin{array}{l}\text { C (1) } \\
H(2) \\
\text { S (1) }\end{array}$ & $\begin{array}{l}\text { Arrancar folha caderno, dobrá-la, desdobrá-la, amassá-la e jogá-la } \\
\text { à frente }\end{array}$ & B (1) & \\
\hline $\begin{array}{l}\text { Caixa para guardar } \\
\text { óculos }\end{array}$ & 1 & 0 & $\begin{array}{l}\text { Fingir que põe e tira óculos de dentro da } \\
\text { caixa e oferecê-los para outras pessoas } \\
\text { colocarem }\end{array}$ & $\mathrm{B}(1)$ & & & & \\
\hline \multirow{5}{*}{$\begin{array}{l}\text { Caixa de fita de } \\
\text { videocassete }\end{array}$} & \multirow{5}{*}{3} & \multirow{5}{*}{3} & & & & $\begin{array}{l}\text { Usar a caixa como se fosse um binóculo (ou filmadora): coloca-a } \\
\text { na horizontal, com o lado menor do retângulo na frente dos olhos } \\
\text { e direciona-a para outras crianças }\end{array}$ & Gi (1) & \\
\hline & & & & & & $\begin{array}{l}\text { Oferecer a caixa para outras crianças, primeiro como caixa, } \\
\text { depois, chamando-a com o nome de alimentos: morango, uva e } \\
\text { chocolate }\end{array}$ & Gi (1) & \\
\hline & & & & & & Bater com a caixa da fita no braço de outra criança; as duas riem & Gi (1) & \\
\hline & & & & & & $\begin{array}{l}\text { Ter uma caixa de fita aproximada e afastada de seu rosto por outra } \\
\text { criança }\end{array}$ & & $\mathrm{Gu}(2)$ \\
\hline & & & & & & Encostar uma leiteira na caixa que outra criança segura & & $\mathrm{Gu}(1)$ \\
\hline \multirow{3}{*}{ Capacete (de plástico) } & \multirow{3}{*}{1} & \multirow{3}{*}{3} & & & & Chutá-lo (com panelinha dentro) & & $\mathrm{C}(1)$ \\
\hline & & & & & & Rodá-lo no chão & & $\mathrm{C}(1)$ \\
\hline & & & & & & "Tirar" frutas da cesta e "colocá-las" num capacete & Gi (1) & $\mathrm{C}(1)$ \\
\hline \multirow{3}{*}{$\begin{array}{l}\text { Carrinho de madeira } \\
\text { com pinos de encaixar }\end{array}$} & \multirow{3}{*}{3} & \multirow{3}{*}{5} & $\begin{array}{l}\text { Encaixar e desencaixar pinos no } \\
\text { carrinho }\end{array}$ & Gi (1) & $\begin{array}{l}\mathrm{Gu}(2) \\
\mathrm{S}(1) \\
\end{array}$ & $\begin{array}{l}\text { Passar ponta dos pinos nos lábios, como se fosse baton (outra } \\
\text { criança passa no sujeito-focal) }\end{array}$ & & $\mathrm{Gu}(1)$ \\
\hline & & & $\begin{array}{l}\text { Encaixar e desencaixar pinos no } \\
\text { carrinho, depois colocar os pinos dentro } \\
\text { do carro de bombeiro }\end{array}$ & $\mathrm{B}(1)$ & & Colocar pinos de madeira em panelinhas e cozinhar & $\mathrm{La}(1)$ & \\
\hline & & & $\begin{array}{l}\text { Empurrar carrinho apoiando-o sobre a } \\
\text { prateleira de uma estante }\end{array}$ & & $\mathrm{C}(1)$ & & & \\
\hline \multirow[t]{3}{*}{$\begin{array}{l}\text { Carrinhos (de bombeiro, } \\
\text { de metal, de madeira, de } \\
\text { plástico, caminhão) }\end{array}$} & \multirow[t]{3}{*}{14} & \multirow[t]{3}{*}{21} & Apertar botões do carro de bombeiros & & $\begin{array}{l}\mathrm{Gu}(1) \\
\mathrm{H}(1) \\
\mathrm{S}(1)\end{array}$ & $\begin{array}{l}\text { Colocar um pé sobre um caminhão de plástico e usá-lo como } \\
\text { skate }\end{array}$ & $\mathrm{B}(1)$ & \\
\hline & & & Empurrar / friccionar carrinho & $\begin{array}{l}\mathrm{B}(2) \\
\mathrm{La}(1) \\
\mathrm{Gi}(1)\end{array}$ & $\begin{array}{l}\mathrm{C}(2) \\
\mathrm{H}(2)\end{array}$ & $\begin{array}{l}\text { Levar carro de bombeiros da mesa ao chão, segurando-o sobre a } \\
\text { cabeça }\end{array}$ & B (1) & \\
\hline & & & $\begin{array}{l}\text { Empurrar carrinho sobre a mesa, falar } \\
\text { "preparar, apontar" e empurrá-lo no } \\
\text { chão }\end{array}$ & & C (1) & $\begin{array}{l}\text { Criança sentada, movimentando carrinho para frente e para trás e } \\
\text { pronunciando o nome dela }\end{array}$ & B (1) & \\
\hline
\end{tabular}




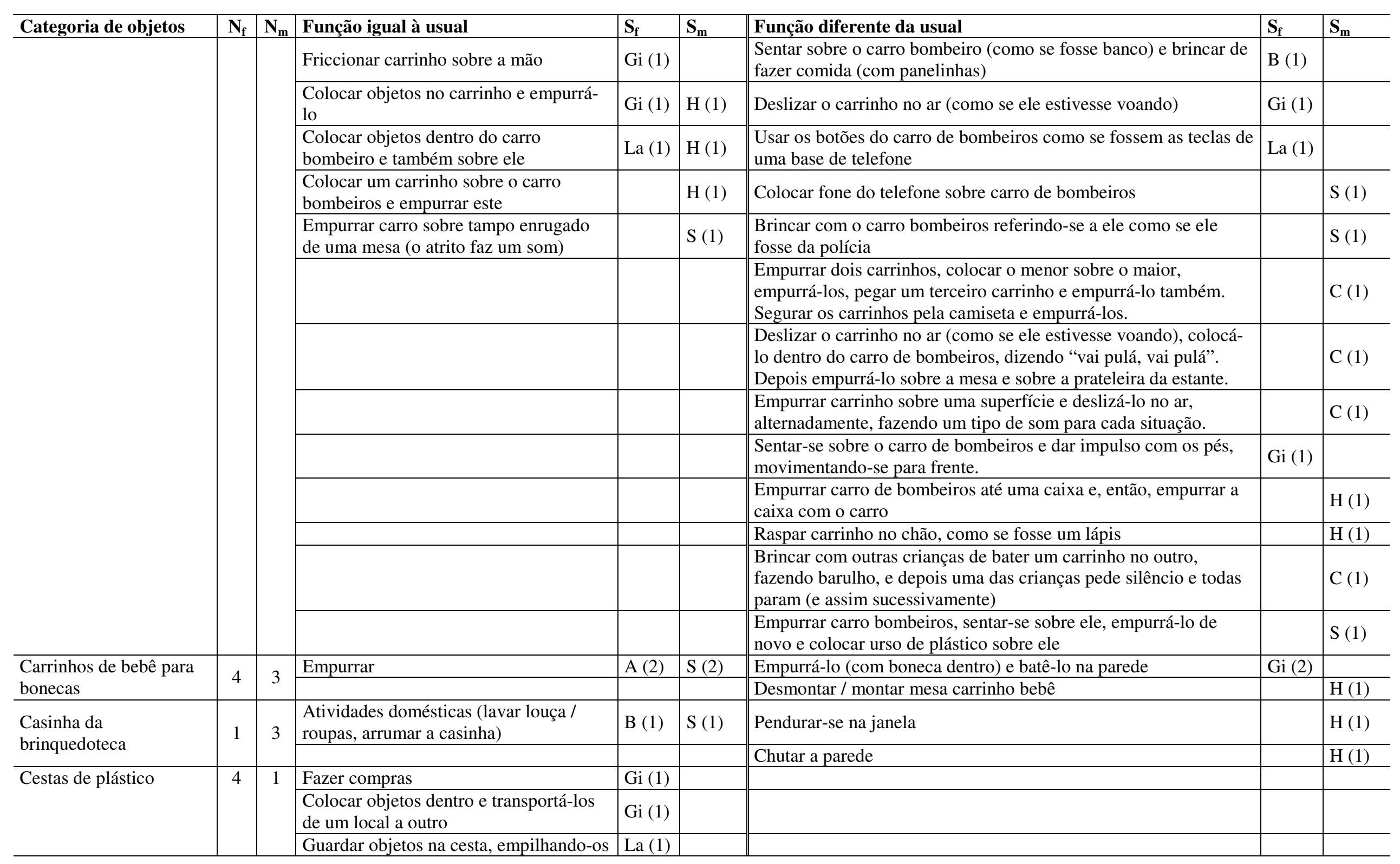




\begin{tabular}{|c|c|c|c|c|c|c|c|c|}
\hline Categoria de objetos & $\mathbf{N}_{\mathrm{f}}$ & $\mathbf{N}_{\mathrm{m}}$ & Função igual à usual & $\mathbf{S}_{\mathbf{f}}$ & $\mathbf{S}_{\mathrm{m}}$ & Função diferente da usual & $\mathbf{S}_{\mathbf{f}}$ & $\mathbf{S}_{\mathrm{m}}$ \\
\hline & & & Encaixar alça e tampa na cesta & Gi (1) & S (1) & & & \\
\hline Colchão & 0 & 1 & & & & $\begin{array}{l}\text { Com uma sacola no braço, a criança diz que vai para a praia. } \\
\text { Então, deita-se sobre um colchão azul, de costas e depois de } \\
\text { frente e finge que está nadando. }\end{array}$ & & $\mathrm{C}(1)$ \\
\hline $\begin{array}{l}\text { Coração de pelúcia com } \\
\text { fio e ventosa na ponta } \\
\text { (para ser pendurado) }\end{array}$ & 0 & 1 & $\begin{array}{l}\text { Percorrer a sala, grudando a ventosa em } \\
\text { alguns móveis e, às vezes, colocando- na } \\
\text { boca. }\end{array}$ & & $\mathrm{C}(1)$ & & & \\
\hline $\begin{array}{l}\text { Embalagem de } \\
\text { termômetro }\end{array}$ & 1 & 0 & Balançá-la, tampá-la e destampá-la & $\mathrm{B}(1)$ & & & & \\
\hline \multirow{4}{*}{$\begin{array}{l}\text { Embalagens de } \\
\text { alimentos (catchup, } \\
\text { mostarda, sorvete, } \\
\text { margarina etc) }\end{array}$} & \multirow{4}{*}{4} & \multirow{4}{*}{4} & Oferecer comida & A (1) & $\mathrm{H}(1)$ & Colocar pote de sorvete na cabeça como se fosse um chapéu & & $\mathrm{H}(1)$ \\
\hline & & & Receber comida & & C (1) & Deixar pote de sorvete cair da cabeça ao chão e rir & & $\mathrm{H}(1)$ \\
\hline & & & $\begin{array}{l}\text { Fazer movimento como se vertesse o } \\
\text { conteúdo de uma embalagem para outra. } \\
\text { Depois beber de uma das embalagens } \\
\text { (lata) }\end{array}$ & Gi (1) & & $\begin{array}{l}\text { Segurar uma embalagem com cada mão e batê-las sobre a mesa, } \\
\text { vocalizando "êh, êh, êh"; entornar uma embalagem sobre a outra, } \\
\text { oferecer bebida de uma e beber da segunda }\end{array}$ & $\mathrm{La}(1)$ & \\
\hline & & & $\begin{array}{l}\text { Entornar uma embalagem sobre outra, } \\
\text { batendo os bocais das duas, como se } \\
\text { quisesse tirar um líquido viscoso de } \\
\text { dentro }\end{array}$ & $\mathrm{La}(1)$ & & & & \\
\hline \multirow{9}{*}{$\begin{array}{l}\text { Embalagens de } \\
\text { cosméticos (xampu, } \\
\text { creme, desodorante) }\end{array}$} & \multirow[t]{9}{*}{10} & \multirow[t]{9}{*}{7} & $\begin{array}{l}\text { Fazer movimento como se vertesse o } \\
\text { conteúdo de uma embalagem para outra }\end{array}$ & A (1) & & Colocar embalagem na boca e "chupá-la", como se fosse chupeta & A (1) & \\
\hline & & & $\begin{array}{l}\text { Virar embalagem de xampu sobre as } \\
\text { mãos e depois esfregá-las }\end{array}$ & $\mathrm{B}(1)$ & & Bater uma embalagem sobre outra(s) & A (1) & \\
\hline & & & Ter o cabelo lavado por outra criança & & $\mathrm{Gu}(1)$ & Receber ar que sai de embalagem apertada por outra criança & $\mathrm{A}(1)$ & \\
\hline & & & $\begin{array}{l}\text { Pegar "creme" da embalagem de xampu } \\
\text { e passá-lo na barriga e nas costas de } \\
\text { outra criança }\end{array}$ & La (1) & & $\begin{array}{l}\text { Virar embalagem de xampu num copinho (como se houvesse } \\
\text { líquido) e passar o "conteúdo" na mão de uma boneca }\end{array}$ & A (1) & \\
\hline & & & $\begin{array}{l}\text { Tentar desrosquear a tampa da } \\
\text { embalagem }\end{array}$ & & $\mathrm{C}(1)$ & $\begin{array}{l}\text { Lavar o próprio cabelo, ter o cabelo lavado por outra criança e } \\
\text { lavar o cabelo de uma terceira criança }\end{array}$ & & $\mathrm{Gu}(1)$ \\
\hline & & & & & & $\begin{array}{l}\text { Verter líquido no cabelo de outra criança, fazendo som com a } \\
\text { boca (ar que passa entre os dentes) }\end{array}$ & & $\mathrm{Gu}(1)$ \\
\hline & & & & & & $\begin{array}{l}\text { Receber remédio de uma embalagem de xampu, em brincadeira } \\
\text { de médico }\end{array}$ & $\mathrm{La}(1)$ & \\
\hline & & & & & & $\begin{array}{l}\text { Receber uma embalagem oferecida por outra criança, virá-la } \\
\text { sobre a cabeça e depois fingir que bebe dela. }\end{array}$ & & $\mathrm{C}(1)$ \\
\hline & & & & & & Virar embalagem de xampu sobre uma bola & Gi (1) & \\
\hline
\end{tabular}




\begin{tabular}{|c|c|c|c|c|c|c|c|c|}
\hline Categoria de objetos & $\mathbf{N}_{\mathrm{f}}$ & $\mathbf{N}_{\mathbf{m}}$ & Função igual à usual & $\mathbf{S}_{\mathbf{f}}$ & $\mathbf{S}_{\mathrm{m}}$ & Função diferente da usual & $\mathbf{S}_{\mathbf{f}}$ & $\mathbf{S}_{\mathrm{m}}$ \\
\hline & & & & & & $\begin{array}{l}\text { Colocar embalagem de xampu sob o braço (axila); ela cai. } \\
\text { Colocar copinho dentro da embalagem }\end{array}$ & & $\mathrm{S}(1)$ \\
\hline & & & & & & Apertar embalagem em direção ao rosto e receber ar que sai dela & & $\mathrm{C}(1)$ \\
\hline & & & & & & Bater embalagem no chão & Gi (1) & \\
\hline Estante de madeira & 2 & 0 & & & & Subir na estante & $\mathrm{La}(1)$ & \\
\hline Estante de madeira & 2 & 0 & & & & $\begin{array}{l}\text { Fingir que está pegando água da estante (como se houvesse uma } \\
\text { torneira ou filtro) numa embalagem de plástico. }\end{array}$ & $\mathrm{La}(1)$ & \\
\hline \multirow{3}{*}{ Ferro de passar roupas } & \multirow{3}{*}{6} & \multirow{3}{*}{0} & $\begin{array}{l}\text { Passar panos / tecidos / roupas de } \\
\text { boneca }\end{array}$ & $\begin{array}{l}\mathrm{B}(1) \\
\mathrm{La}(3)\end{array}$ & & & & \\
\hline & & & $\begin{array}{l}\text { Ficar próxima a outra criança que está } \\
\text { passando roupas e dizer que está } \\
\text { ajudando a mamãe a passar roupas }\end{array}$ & $\mathrm{Gi}(1)$ & & & & \\
\hline & & & $\begin{array}{l}\text { Passar roupas, utilizando um copinho } \\
\text { para molhá-las }\end{array}$ & $\mathrm{Li}(1)$ & & & & \\
\hline Fronha & 0 & 1 & & & & $\begin{array}{l}\text { Segurando uma fronha cheia de objetos, a criança diz que é o } \\
\text { Papai Noel; oferece e dá objetos para outra criança }\end{array}$ & & $\mathrm{S}(1)$ \\
\hline \multirow[t]{2}{*}{$\begin{array}{l}\text { Geladeira, fogão, } \\
\text { máquina de lavar roupas }\end{array}$} & \multirow[t]{2}{*}{3} & \multirow[t]{2}{*}{2} & $\begin{array}{l}\text { Atividades domésticas (cozinhar, lavar } \\
\text { roupas) }\end{array}$ & $\begin{array}{l}\mathrm{La}(1) \\
\mathrm{Gi}(1)\end{array}$ & $\mathrm{H}(1)$ & $\begin{array}{l}\text { Colocar cavalinho de plástico e travesseiro infantil dentro da } \\
\text { máquina de lavar roupas, girar o botão dela e sentar-se sobre ela. } \\
\text { Depois tirar objetos da máquina }\end{array}$ & $\mathrm{La}(1)$ & \\
\hline & & & Girar botões do fogão & & S (1) & & & \\
\hline Lápis de cor, giz de cera & 0 & 1 & & & & $\begin{array}{l}\text { Colocar lápis na própria boca, num pote e perto da boca de um } \\
\text { colega, como se fosse um talher }\end{array}$ & A (1) & \\
\hline \multirow{2}{*}{ Livro de estórias inflado } & \multirow{2}{*}{1} & \multirow{2}{*}{1} & & & & Pegar comida do livro com um garfo & $\mathrm{B}(1)$ & \\
\hline & & & & & & Segurar livro por uma de suas páginas e balançá-lo & & $\mathrm{Gu}(1)$ \\
\hline \multirow{8}{*}{ Mesas, cadeiras } & \multirow{8}{*}{5} & \multirow{8}{*}{4} & $\begin{array}{l}\text { Tirar e recolocar o tampo removível de } \\
\text { uma mesa }\end{array}$ & Gi (1) & & Empilhar cadeiras & & $\mathrm{C}(1)$ \\
\hline & & & & & & Ficar sob a mesa com outras crianças & & $\mathrm{C}(1)$ \\
\hline & & & & & & Referir-se a uma cadeira como se ela fosse um avião & Gi (1) & \\
\hline & & & & & & Andar segurando a cadeira perto das costas & Gi (1) & \\
\hline & & & & & & Empurrar a cadeira de um local a outro (como um carrinho) & Gi (1) & \\
\hline & & & & & & $\begin{array}{l}\text { Fazer movimentos de mexer com uma colher, dentro da caixa que } \\
\text { existe sob o tampo de uma mesa. Depois, bater a colher na borda, } \\
\text { como se estivesse tentando limpá-la }\end{array}$ & & $\mathrm{Gu}(1)$ \\
\hline & & & & & & Tentar subir / subir sobre a mesa & $\mathrm{A}(1)$ & \\
\hline & & & & & & $\begin{array}{l}\text { Ficar atrás delas, como esconderijos (para fugir de crianças } \\
\text { maiores, que eram os bichos) }\end{array}$ & & $S(1)$ \\
\hline
\end{tabular}




\begin{tabular}{|c|c|c|c|c|c|c|c|c|}
\hline Categoria de objetos & $\mathbf{N}_{\mathrm{f}}$ & $\mathbf{N}_{\mathrm{m}}$ & Função igual à usual & $\mathbf{S}_{\mathrm{f}}$ & $\mathbf{S}_{\mathrm{m}}$ & Função diferente da usual & $\mathbf{S}_{\mathrm{f}}$ & $\mathbf{S}_{\mathrm{m}}$ \\
\hline $\begin{array}{l}\text { Objetos não } \\
\text { identificados (pequenos) }\end{array}$ & 0 & 1 & Pegar, mexer, manipular & & $\mathrm{Gu}(1)$ & & & \\
\hline \multirow{4}{*}{ Panos, lenços, tecidos } & \multirow{4}{*}{6} & \multirow{4}{*}{3} & Dobrar / desdobrar & $\begin{array}{l}\text { A (1) } \\
\operatorname{Li}(1)\end{array}$ & & Passar pano dobrado sobre o rosto de uma boneca & $\mathrm{A}(1)$ & \\
\hline & & & $\begin{array}{l}\text { Estender lenço sobre o chão e bater a } \\
\text { mão sobre o lenço }\end{array}$ & & $\mathrm{Gu}(1)$ & $\begin{array}{l}\text { Estender pano sobre o chão, colocar panela e colher sobre ele, } \\
\text { bater palmas e cobrir a panela com o pano }\end{array}$ & & $\mathrm{Gu}(1)$ \\
\hline & & & $\begin{array}{l}\text { Colocar pano sobre a mesa e tentar } \\
\text { pegar o ferro de passar roupas que } \\
\text { estava com outra criança }\end{array}$ & & $\mathrm{Gu}(1)$ & $\begin{array}{l}\text { Encostar pano na bochecha de uma criança mais nova, apertá-la e } \\
\text { fazer carinho no rosto da criança }\end{array}$ & $\mathrm{La}(1)$ & \\
\hline & & & Estender sobre o chão / mesa / colchão & $\begin{array}{l}\mathrm{Li}(1) \\
\mathrm{La}(1) \\
\end{array}$ & & & & \\
\hline \multirow{10}{*}{$\begin{array}{l}\text { Peças de plástico, de } \\
\text { madeira }\end{array}$} & \multirow{10}{*}{12} & \multirow{10}{*}{18} & Reunir as peças que estavam espalhadas & & $\mathrm{C}(1)$ & Atirá-las na parede & & $\mathrm{Gu}(4)$ \\
\hline & & & Guardá-las & & $\begin{array}{l}\mathrm{C}(1) \\
\mathrm{Gu}(1) \\
\end{array}$ & Empurrar com o pé uma peça & & $\mathrm{Gu}(1)$ \\
\hline & & & $\begin{array}{l}\text { Encaixar / desencaixar peças de madeira } \\
\text { no carrinho }\end{array}$ & & $\mathrm{Gu}(3)$ & Empilhar peças sobre um prato & $\mathrm{A}(2)$ & \\
\hline & & & $\begin{array}{l}\text { Levá-las de um local a outro, onde as } \\
\text { guarda }\end{array}$ & $\mathrm{La}(1)$ & & $\begin{array}{l}\text { Bater peça sobre a mesa, fazendo barulho e pulando sem sair do } \\
\text { lugar }\end{array}$ & $\mathrm{B}(1)$ & \\
\hline & & & $\begin{array}{l}\text { Encaixar / desencaixar peças grandes } \\
\text { (tipo Lego) umas sobre as outras, } \\
\text { formando uma torre }\end{array}$ & $\mathrm{Gi}(1)$ & $\mathrm{H}(1)$ & $\begin{array}{l}\text { Fazer comida, usando peças de madeira como se fossem } \\
\text { recipientes contendo sal ou temperos }\end{array}$ & $\mathrm{B}(1)$ & \\
\hline & & & $\begin{array}{l}\text { Juntar e bater peças uma na outra; } \\
\text { depois encostar uma peça na parede, } \\
\text { emitindo sons com a boca }\end{array}$ & & $\mathrm{Gu}(1)$ & $\begin{array}{l}\text { Bater peças no chão e colocá-las na própria testa, deixando-as } \\
\text { escorregar }\end{array}$ & & $\mathrm{Gu}(1)$ \\
\hline & & & $\begin{array}{l}\text { Movimentar peças em forma de boneco } \\
\text { na frente de outras peças iguais } \\
\text { seguradas por outra criança }\end{array}$ & $\mathrm{La}(1)$ & & Empurrar peça no chão, dando impulso até ela chegar na parede & & $\mathrm{Gu}(1)$ \\
\hline & & & $\begin{array}{l}\text { Desmontar um conjunto de peças em } \\
\text { forma de boneco e guardá-las numa } \\
\text { caixa }\end{array}$ & $\mathrm{La}(1)$ & & $\begin{array}{l}\text { Brincar de médico: uma criança passa uma peça na barriga de } \\
\text { outra }\end{array}$ & & $\begin{array}{l}\mathrm{H}(1) \\
\mathrm{S}(2)\end{array}$ \\
\hline & & & $\begin{array}{l}\text { Dar peças para outra criança que estava } \\
\text { encaixando e empilhando peças tipo } \\
\text { Lego }\end{array}$ & $\mathrm{La}(2)$ & & $\begin{array}{l}\text { Cantar parabéns e assoprar (velas imaginárias) com outra criança, } \\
\text { olhando para o objeto que construíram com peças tipo Lego }\end{array}$ & $\mathrm{La}(1)$ & \\
\hline & & & Encaixar peças tipo Lego (construção) & La (1) & & & & \\
\hline $\begin{array}{l}\text { Pentes, escovas de } \\
\text { cabelo }\end{array}$ & 3 & 2 & $\begin{array}{l}\text { Ter o cabelo escovado / penteado por } \\
\text { outra criança }\end{array}$ & & $\mathrm{Gu}(1)$ & Fazê-los de bonecos (um na frente do outro, “conversando”) & Gi (1) & \\
\hline
\end{tabular}




\begin{tabular}{|c|c|c|c|c|c|c|c|c|}
\hline Categoria de objetos & $\mathbf{N}_{\mathbf{f}}$ & $\mathbf{N}_{\mathbf{m}}$ & Função igual à usual & $\mathbf{S}_{\mathbf{f}}$ & $\mathbf{S}_{\mathrm{m}}$ & Função diferente da usual & $\mathbf{S}_{\mathrm{f}}$ & $\mathbf{S}_{\mathrm{m}}$ \\
\hline & & & $\begin{array}{l}\text { Escovar o cabelo frente a frente com } \\
\text { outra criança que também escova o } \\
\text { cabelo. }\end{array}$ & & $\mathrm{C}(1)$ & Passar duas escovas, uma de cada vez, no cabelo & $\operatorname{Li}(1)$ & \\
\hline & & & & & & Passar duas escovas e um espelho um sobre o outro & $\operatorname{Li}(1)$ & \\
\hline $\begin{array}{l}\text { Potes para guardar lápis } \\
\text { e giz de cera }\end{array}$ & 1 & 0 & & & & Colocar parte do rosto (boca) dentro do pote & A (1) & \\
\hline Quebra-cabeças & 1 & 2 & Montar / desmontar & A (1) & $\begin{array}{l}\mathrm{C}(1) \\
\mathrm{H}(1)\end{array}$ & & & \\
\hline \multirow{3}{*}{$\begin{array}{l}\text { Recipiente para guardar } \\
\text { peças tipo Lego }\end{array}$} & \multirow{3}{*}{3} & \multirow{3}{*}{1} & $\begin{array}{l}\text { Chacoalhar recipiente contendo peças, o } \\
\text { que faz barulho }\end{array}$ & & $\mathrm{H}(1)$ & $\begin{array}{l}\text { Fingir que tem líquido ou gelo dentro do recipiente e molhar } \\
\text { alimento no líquido. Fazer movimento como se o lavasse ou o } \\
\text { enchesse de água. }\end{array}$ & Gi (1) & \\
\hline & & & & & & Bater sobre o fundo do recipiente, como se fosse um tambor & $\mathrm{La}(1)$ & \\
\hline & & & & & & $\begin{array}{l}\text { Colocar peças tipo Lego umas sobre as outras, apoiadas sobre o } \\
\text { fundo da embalagem (com a abertura para baixo) }\end{array}$ & $\mathrm{La}(1)$ & \\
\hline $\begin{array}{l}\text { Relógio-despertador de } \\
\text { mesa }\end{array}$ & 0 & 1 & Girar ponteiros & & $\mathrm{H}(1)$ & & & \\
\hline \multirow{5}{*}{$\begin{array}{l}\text { Revistas, livros, folhetos } \\
\text { de supermercado }\end{array}$} & \multirow{5}{*}{7} & \multirow{5}{*}{14} & Ver, folhear & $\begin{array}{l}\text { A (3) } \\
\mathrm{La}(2)\end{array}$ & $\begin{array}{l}\mathrm{Gu}(2) \\
\mathrm{H}(1) \\
\mathrm{S}(2)\end{array}$ & $\begin{array}{l}\text { Após duas crianças dizerem uma para a outra que encontraram um } \\
\text { pato nas revistinhas que olhavam, as duas encostam suas } \\
\text { revistinhas uma na outra (como se as pareasse ou os patos se } \\
\text { beijassem) }\end{array}$ & & $S(1)$ \\
\hline & & & Contar estória & $\mathrm{La}(1)$ & S (1) & Enrolar a revistinha, formando um tubo, e vocalizar dentro dela & & S (1) \\
\hline & & & $\begin{array}{l}\text { Ver, folhear e falar o nome de algumas } \\
\text { personagens que reconhecia }\end{array}$ & $\mathrm{A}(1)$ & & $\begin{array}{l}\text { Abraçar a revistinha, enrolá-la e colocá-la sob o braço (axila). } \\
\text { Pegar outra revistinha, enrolá-la e vocalizar dentro do tubo } \\
\text { formado }\end{array}$ & & $S(1)$ \\
\hline & & & $\begin{array}{l}\text { Ouvir estória contada por outra criança e } \\
\text { participar da narrativa }\end{array}$ & & $\begin{array}{l}\text { C (1) } \\
\text { S (1) }\end{array}$ & Colocar revistinhas enroladas sob o braço (axila) & & $S(1)$ \\
\hline & & & $\begin{array}{l}\text { Fingir ler revistinha: olha-a, folheia-a, } \\
\text { vocaliza }\end{array}$ & & $\mathrm{S}(1)$ & $\begin{array}{l}\text { Enrolar revistinha, formando um tubo, e despejar seu "conteúdo" } \\
\text { sobre panelas que estão sobre a mesa. Colocar panela no fogão }\end{array}$ & & $S(1)$ \\
\hline Sapatinhos de boneca & 1 & 0 & $\begin{array}{l}\text { Experimentar sapatinho em algumas } \\
\text { bonecas, tentando encontrar um pé em } \\
\text { que ele cabe }\end{array}$ & Gi (1) & & & & \\
\hline \multirow[b]{2}{*}{ Secadores de cabelo } & \multirow[b]{2}{*}{1} & \multirow[b]{2}{*}{0} & Ter o cabelo secado por outra criança & & $\mathrm{H}(1)$ & Usá-lo como arma (revolver), para atirar & B (1) & H (3) \\
\hline & & & & & & $\begin{array}{l}\text { Bater secador em objetos, como se fosse um martelo, mas fazendo } \\
\text { som de arma }\end{array}$ & & $\mathrm{H}(1)$ \\
\hline $\begin{array}{l}\text { "Sofá" (feito de caixas } \\
\text { de leite longa-vida) }\end{array}$ & 0 & 2 & Subir sobre & & $\mathrm{H}(1)$ & Sentar sobre o encosto do "sofá" e balançar-se & & $\mathrm{H}(1)$ \\
\hline
\end{tabular}




\begin{tabular}{|c|c|c|c|c|c|c|c|c|}
\hline Categoria de objetos & $\mathbf{N}_{\mathbf{f}}$ & $\mathbf{N}_{\mathbf{m}}$ & Função igual à usual & $\mathbf{S}_{\mathbf{f}}$ & $\mathbf{S}_{\mathrm{m}}$ & Função diferente da usual & $\mathbf{S}_{\mathbf{f}}$ & $\mathbf{S}_{\mathbf{m}}$ \\
\hline \multirow{4}{*}{ Tampas de embalagens } & \multirow{4}{*}{0} & \multirow{4}{*}{5} & & & & Girar tampa sobre o chão & & $\begin{array}{l}\mathrm{H}(1) \\
\mathrm{Gu}(1)\end{array}$ \\
\hline & & & & & & Bater uma tampa na outra (como pratos de orquestra) & & $\mathrm{H}(1)$ \\
\hline & & & & & & Bater tampa sobre a mesa & & $\mathrm{H}(1)$ \\
\hline & & & & & & Outra criança bate tampa na cabeça do sujeito-focal & & $\mathrm{H}(1)$ \\
\hline $\begin{array}{l}\text { Telefones, suas partes ou } \\
\text { celulares }\end{array}$ & 3 & 2 & Falar ao telefone & $\mathrm{La}(2)$ & $\mathrm{Gu}(2)$ & $\begin{array}{l}\text { Usar telefone celular como medicamento em brincadeira de } \\
\text { médico }\end{array}$ & $\mathrm{La}(1)$ & \\
\hline Torneira e pia & 1 & 0 & Lavar louça & $\mathrm{B}(1)$ & & & & \\
\hline \multirow{13}{*}{$\begin{array}{l}\text { Utensílios de cozinha } \\
\text { Utensílios de cozinha } \\
\text { (panelas, talheres, copos, } \\
\text { potes, pratos, xícaras etc) }\end{array}$} & & & Fazer comida e comer & $\mathrm{A}(2)$ & & Girar faquinha de plástico no chão & & $\mathrm{C}(1)$ \\
\hline & \multirow{12}{*}{16} & \multirow{12}{*}{26} & Fazer comida e oferecer & A (1) & & $\begin{array}{l}\text { Fazer comida (parece líquida), colocando e vertendo algo de um } \\
\text { pote para outro. Vai até a parede e faz movimento como se } \\
\text { pegasse água de um filtro. }\end{array}$ & & $\mathrm{Gu}(1)$ \\
\hline & & & Fazer comida & $\begin{array}{l}\text { A (2) } \\
\text { Gi (2) } \\
\mathrm{La}(1)\end{array}$ & $\begin{array}{l}\mathrm{C}(1) \\
\mathrm{Gu}(3) \\
\mathrm{H}(1) \\
\end{array}$ & Bater pote ou colher sobre a mesa & & $\mathrm{Gu}(2)$ \\
\hline & & & Dar comida para outra criança & $\mathrm{B}(1)$ & & Empilhar potes sobre a mesa & & $\mathrm{Gu}(1)$ \\
\hline & & & Colocar moeda dentro do pote & & $\mathrm{Gu}(1)$ & Bater a mão sobre a boca do pote & & $\mathrm{Gu}(1)$ \\
\hline & & & Comer / beber & $\begin{array}{l}\mathrm{Gi}(1) \\
\mathrm{Li}(1) \\
\mathrm{La}(1)\end{array}$ & $\begin{array}{l}\mathrm{C}(1) \\
\mathrm{Gu}(2)\end{array}$ & $\begin{array}{l}\text { Transportar pratinho segurando-o com a boca e balançando a } \\
\text { cabeça, enquanto anda }\end{array}$ & Gi (1) & \\
\hline & & & $\begin{array}{l}\text { Virar panela sobre copinho, pegar } \\
\text { copinhos e levá-los de uma mesa a outra }\end{array}$ & & $\mathrm{Gu}(1)$ & $\begin{array}{l}\text { Colocar panela virada para baixo sobre pano e bater palmas, como } \\
\text { se estivesse cantando parabéns (vocaliza "êh" e "dá, dá, dá") }\end{array}$ & & $\mathrm{Gu}(1)$ \\
\hline & & & $\begin{array}{l}\text { Encaixar e desencaixar um copinho no } \\
\text { outro }\end{array}$ & & $\mathrm{Gu}(1)$ & Comer, enquanto tem seu cabelo cortado por outra criança & & $\mathrm{Gu}(1)$ \\
\hline & & & Mexer colher dentro de uma panela & & $\mathrm{Gu}(1)$ & $\begin{array}{l}\text { Oferecer comida (colher) para outra criança que toca tesoura na } \\
\text { colher }\end{array}$ & & $\mathrm{Gu}(1)$ \\
\hline & & & Oferecer comida & & $\mathrm{Gu}(2)$ & $\begin{array}{l}\text { Virar o prato p/ baixo e bater colher sobre ele, acompanhando } \\
\text { música cantada por outra criança }\end{array}$ & & $\mathrm{Gu}(1)$ \\
\hline & & & Bater uma peça na outra & $\mathrm{La}(1)$ & Gu (1) & Jogar panela e pizza de plástico para frente & & $\mathrm{S}(1)$ \\
\hline & & & $\begin{array}{l}\text { Tampar e destampar panelas, segurando } \\
\text { boneca no braço }\end{array}$ & $\operatorname{Li}(1)$ & & & & \\
\hline & & & $\begin{array}{l}\text { Transferir panelas de uma mesa para } \\
\text { outra e guardá-las sob o tampo } \\
\text { removível da segunda mesa }\end{array}$ & $\operatorname{Li}(1)$ & & & & \\
\hline
\end{tabular}


APÊNDICE 15 - Categorias de objetos com os quais se observou as crianças brincando durante as últimas sessões de cada dupla, número total de maneiras como os objetos foram utilizados, modos de utilização dos mesmos e os sujeitos agentes da ação (ou

brincadeira). OBS.: a) Os números e letras referem-se à descrição dos objetos contidos no Apêndice 2; b) As seguintes notações que aparecem com as iniciais dos nomes das crianças significam: " $"$ " = criança agente da ação em dupla com outra criança; "“_"= crianças brincando juntas com os mesmos objetos (ambas agentes); "imt" = imita (observa e faz o mesmo que a outra criança).

\begin{tabular}{|c|c|c|c|c|c|}
\hline Categoria de objetos $^{1}$ & $\mathbf{N}$ & Função igual à usual & Sujeitos $^{2}$ & Função diferente da usual & Sujeitos $^{2}$ \\
\hline \multirow{5}{*}{$\begin{array}{l}\text { Acessórios (bolsas, } \\
\text { sacolas - 3.i, 12.d) }\end{array}$} & \multirow{5}{*}{10} & Abrir e fechar (bolsa) & $\mathrm{H} / \mathrm{C}(2)$ & Colocar bolsa sobre a própria cabeça & $\mathrm{Li} / \mathrm{C}$ \\
\hline & & Segurar bolsa e ir fazer compras & $\begin{array}{l}\mathrm{C}-\mathrm{Li} \\
\mathrm{Li} / \mathrm{C}\end{array}$ & Fingir que tira algo de dentro da bolsa e que dá para o boneco & $\mathrm{H} / \mathrm{C}$ \\
\hline & & Colocar objetos dentro da bolsa / sacola & C-Li & & \\
\hline & & Segurar bolsas & Gi-Li & & \\
\hline & & Colocar sacola no ombro & H/A (2) & & \\
\hline \multirow[t]{13}{*}{ Bambolês (1.d) } & \multirow[t]{13}{*}{30} & Colocar bambolê(s) no pescoço & \begin{tabular}{|l|}
$\mathrm{La} / \mathrm{B}$ \\
$\mathrm{H}-\mathrm{S}$ \\
\end{tabular} & $\begin{array}{l}\text { Fingir que o bambolê é uma bolsa ("faz q isto é uma bolsa, tá?"): } \\
\text { coloca o bambolê cruzado no corpo, a tira-colo }\end{array}$ & $\mathrm{Gi} / \mathrm{A}$ \\
\hline & & $\begin{array}{l}\text { Segurar um bambolê em cada mão e movimentá-los no } \\
\text { ar }\end{array}$ & $\mathrm{La} / \mathrm{B}(2)$ & Girar o bambolê posicionado na vertical, sobre o chão & $\mathrm{La} / \mathrm{B}$ \\
\hline & & Movimentar bambolê(s) no ar & $\mathrm{C}-\mathrm{Gi}$ & Bater o bambolê no chão & $\begin{array}{l}\mathrm{La} / \mathrm{B} \\
\mathrm{H} / \mathrm{Gi} \\
\mathrm{Gi} \text { imt H } \\
\end{array}$ \\
\hline & & Oferecer bambolê para outra criança & $\mathrm{Gi} / \mathrm{A}$ & $\begin{array}{l}\text { Empurrar o bambolê posicionado na vertical, sobre o chão, como se } \\
\text { ele fosse uma roda }\end{array}$ & $\mathrm{La} / \mathrm{B}$ \\
\hline & & Jogar bambolê & $\mathrm{Gi} / \mathrm{H}$ & $\begin{array}{l}\text { Empurrar dois bambolês juntos, posicionados na vertical, sobre o } \\
\text { chão, como se eles fossem uma roda }\end{array}$ & $\mathrm{La} / \mathrm{B}$ \\
\hline & & & & $\begin{array}{l}\text { Colocar bambolês "deitados" sobre o chão, agachar-se no centro } \\
\text { deles e contar até } 10\end{array}$ & $\mathrm{La} / \mathrm{B}$ \\
\hline & & & & Olhar pelo vão do bambolê para outra criança e dizer “oi” & $\mathrm{Gi} / \mathrm{C}$ \\
\hline & & & & $\begin{array}{l}\text { Ficar (em pé, sentado, agachado) no centro de um bambolê que } \\
\text { estava "deitado" sobre o chão }\end{array}$ & $\mathrm{Gi} / \mathrm{C}$ \\
\hline & & & & Encostar bambolê na observadora e fazer som & \begin{tabular}{|l|}
$\mathrm{H} / \mathrm{Gi}$ \\
$\mathrm{Gi}$ imt H \\
\end{tabular} \\
\hline & & & & Bater um bambolê em outro que estava no chão & $\mathrm{H} / \mathrm{Gi}$ \\
\hline & & & & $\begin{array}{l}\text { Segurar bambolê na frente do rosto como se fosse um espelho e } \\
\text { dizer "olha isso! Mais bela que eu não existe!" (Branca-de-Neve) }\end{array}$ & $\mathrm{Gi} / \mathrm{H}$ \\
\hline & & & & $\begin{array}{l}\text { Uma criança diz que ela é o menino e a outra é o lobo e tenta pegá- } \\
\text { la usando o bambolê }\end{array}$ & $\mathrm{Gi} / \mathrm{H}$ \\
\hline & & & & Colocar o bambolê no pescoço de outra criança & $\mathrm{H} / \mathrm{Gi}$ \\
\hline
\end{tabular}




\begin{tabular}{|c|c|c|c|c|c|}
\hline Categoria de objetos $^{1}$ & $\mathbf{N}$ & Função igual à usual & Sujeitos $^{2}$ & Função diferente da usual & Sujeitos $^{2}$ \\
\hline & & & & Deitar-se no chão com o bambolê no pescoço & $\mathrm{Gi} / \mathrm{H}$ \\
\hline & & & & $\begin{array}{l}\text { Duas crianças usam o bambolê como se fosse uma espada e } \\
\text { brincam de lutar uma com a outra }\end{array}$ & $\mathrm{Gi}-\mathrm{H}$ \\
\hline & & & & Arrastar bambolê no chão, empurrando objetos com ele & $\begin{array}{l}\mathrm{Gi} / \mathrm{H} \\
\mathrm{H} \text { imt Gi }\end{array}$ \\
\hline & & & & $\begin{array}{l}\text { Arrastar bambolê no chão, empurrando objetos com ele, fazendo } \\
\text { som de carro }\end{array}$ & $\mathrm{Gi} / \mathrm{H}$ \\
\hline & & & & Bater com o bambolê em outro objeto & $\begin{array}{l}\mathrm{Gi} / \mathrm{H} \\
\mathrm{H} / \mathrm{Gi} \\
\end{array}$ \\
\hline Barris de plástico (1.i) & & Abrí-los e tirar um de dentro do outro & $\begin{array}{l}\mathrm{B} / \mathrm{La} \\
\mathrm{La} / \mathrm{B}(2) \\
\mathrm{Gi} / \mathrm{C}\end{array}$ & Colocá-los na boca, como se estivesse bebendo deles & $\begin{array}{l}\mathrm{A} / \mathrm{La} \\
\mathrm{C} / \mathrm{Gi} \\
\mathrm{Gi} / \mathrm{C}(3)\end{array}$ \\
\hline \multirow{9}{*}{ Barris de plástico (1.i) } & \multirow{9}{*}{53} & Abrir / fechar barris & $\begin{array}{l}\text { A/Gi } \\
\mathrm{La} / \mathrm{B} \\
\mathrm{B} \text { imt La } \\
\text { B-La } \\
\text { C/Gi (6) } \\
\text { Gi/C (3) } \\
\text { H/S } \\
\end{array}$ & Chamar o barril de "copo" & $\mathrm{Gi} / \mathrm{A}$ \\
\hline & & Abrir cada barril e colocá-los sobre o chão, como potes & $\mathrm{La} / \mathrm{B}$ & Jogar barris fechados no chão para abrí-los & $\mathrm{B} / \mathrm{La}(4)$ \\
\hline & & $\begin{array}{l}\text { Tentar abrir barris girando, uma metade em sentido } \\
\text { contrário ao da outra (eles só abrem se suas partes forem } \\
\text { puxadas em sentidos contrários) }\end{array}$ & $\begin{array}{l}\mathrm{A} / \mathrm{Gi} \\
\mathrm{S} / \mathrm{Gu} \\
\mathrm{Gu} \text { imt } \mathrm{S}\end{array}$ & $\begin{array}{l}\text { Rolar barris fechados e deitados sobre a cadeira, empurrando-os de } \\
\text { um lado para o outro }\end{array}$ & $\mathrm{B} / \mathrm{La}$ \\
\hline & & $\begin{array}{l}\text { Abrir barris girando e puxando suas metades em sentidos } \\
\text { contrários }\end{array}$ & $\mathrm{A} / \mathrm{Gi}$ & Equilibrar um barril sobre uma garrafinha & $\begin{array}{l}\mathrm{C} / \mathrm{Gi}(2) \\
\mathrm{Gi} \text { imt C }\end{array}$ \\
\hline & & Chacoalhar barris & $\mathrm{Gu} / \mathrm{S}$ & Oferecer "bebida" de um barril aberto (copo) para outra criança & $\begin{array}{l}\text { Gi/C } \\
\mathrm{C} / \mathrm{Gi}(2)\end{array}$ \\
\hline & & Bater um barril no outro (o que faz barulho) & $\mathrm{Gu} / \mathrm{S}$ & $\begin{array}{l}\text { Estender o braço, segurando na mão metade de um barril, em } \\
\text { direção a outra criança. Diz "ete" (este? / leite?) }\end{array}$ & $\mathrm{H} / \mathrm{Gi}$ \\
\hline & & Jogar partes dos barris no chão & $\mathrm{Gu} / \mathrm{S}$ & Usar metade do barril para dar comida para a boneca & $\mathrm{Gi} / \mathrm{H}$ \\
\hline & & $\begin{array}{l}\text { Colocar alguns barris um dentro do outro, empilhar os } \\
\text { restantes sobre estes e suspender o que construiu (cai } \\
\text { tudo) }\end{array}$ & $\mathrm{H} / \mathrm{S}$ & Jogar as metades dos barris para cima & $\mathrm{H} / \mathrm{S}$ \\
\hline & & Bater barris abertos (metades dos barris) sobre a mesa & $\begin{array}{l}\mathrm{Gi} / \mathrm{C} \\
\mathrm{C} \text { imt Gi }\end{array}$ & Chutar as metades dos barris & $\mathrm{H} / \mathrm{S}$ \\
\hline
\end{tabular}




\begin{tabular}{|c|c|c|c|c|c|}
\hline Categoria de objetos $^{1}$ & $\mathbf{N}$ & Função igual à usual & Sujeitos $^{2}$ & Função diferente da usual & Sujeitos $^{2}$ \\
\hline \multirow{3}{*}{ Bóias de cintura (4.d) } & \multirow{3}{*}{125} & Girar a bóia em torno da cintura & \begin{tabular}{|l|}
$\mathrm{A} / \mathrm{B}$ \\
$\mathrm{B}$ imt $\mathrm{A}$ \\
$\mathrm{La} / \mathrm{A}$ \\
$\mathrm{A} / \mathrm{La}$ \\
$\mathrm{Li} / \mathrm{B}(2)$ \\
$\mathrm{Gi} / \mathrm{Gu}$ \\
\end{tabular} & Chamar a bóia de "piscina" & $\begin{array}{l}\mathrm{B} / \mathrm{A} \\
\mathrm{B} / \mathrm{Gu}\end{array}$ \\
\hline & & Colocar a bóia na cintura & $\begin{array}{l}\mathrm{A} / \mathrm{B} \\
\mathrm{A} / \mathrm{La}(2) \\
\mathrm{Gi} / \mathrm{Li} \\
\end{array}$ & $\begin{array}{l}\text { Girar em torno de si com os pés no centro da bóia, falando "roda, } \\
\text { roda, roda... ai, ai, ai". }\end{array}$ & $\begin{array}{l}\mathrm{A} / \mathrm{B} \\
\mathrm{B} \text { imt A }\end{array}$ \\
\hline & & Colocar a bóia sobre os ombros (no pescoço) & \begin{tabular}{|l|}
$\mathrm{B} / \mathrm{A}$ \\
$\mathrm{Gu} / \mathrm{B}$ \\
$\mathrm{B}-\mathrm{Gu}$ \\
$\mathrm{H} / \mathrm{C}$ \\
$\mathrm{C} / \mathrm{H}$ \\
$\mathrm{Gi} / \mathrm{Gu}$ \\
$\mathrm{H} / \mathrm{Gu}(2)$ \\
$\mathrm{Gu}$ imt $\mathrm{H}$ \\
\end{tabular} & $\begin{array}{l}\text { Girar em torno de si com os pés no centro da bóia, falando "roda, } \\
\text { roda, roda... ai, ai, ai". Depois "cair" no chão (com barriga para } \\
\text { baixo). As duas riem e repetem a brincadeira (antes falam "de } \\
\text { novo") }\end{array}$ & A imt B \\
\hline \multirow[t]{4}{*}{ Bóias de cintura (4.d) } & \multirow[t]{4}{*}{ 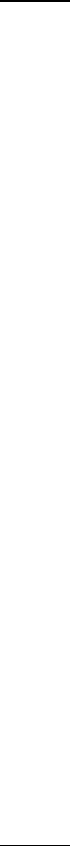 } & Trocar de bóias & $\begin{array}{l}\text { A-B } \\
\text { B-Gui }\end{array}$ & $\begin{array}{l}\text { Girar em torno de si, lado a lado, com os pés no centro da bóia, } \\
\text { falando "assim, assim, assim..." até uma delas dar um grito, o sinal } \\
\text { para "caírem no chão. Riem. Depois de algumas vezes, B pede para } \\
\text { A trocar de bóia e ela aceita. Continuam antes de repetirem, falam } \\
\text { "de novo". B propõe de colocarem a face da bóia que estava para } \\
\text { baixo (face com desenhos), para cima. A aceita }\end{array}$ & A-B \\
\hline & & Sentar-se sobre a bóia (cada criança com uma bóia) & $\begin{array}{l}\mathrm{B} / \mathrm{A} \\
\mathrm{Gu} / \mathrm{Gi} \\
\mathrm{Gi} \text { imt } \\
\mathrm{Gu} \\
\mathrm{S} / \mathrm{La} \mathrm{(2)} \\
\mathrm{La} \text { imt S } \\
\mathrm{A} / \mathrm{La} \\
\mathrm{A}-\mathrm{La} \\
\mathrm{B} / \mathrm{Gu}(2) \\
\mathrm{Gu} / \mathrm{B} \\
\mathrm{C}-\mathrm{Li} \\
\end{array}$ & Pisar sobre a bóia, fazendo barulho & $\begin{array}{l}\mathrm{B} / \mathrm{A} \\
\mathrm{Gu} / \mathrm{Gi}\end{array}$ \\
\hline & & Segurar a bóia ao lado do próprio corpo & $\mathrm{A} / \mathrm{La}$ & Girar em torno de si com os pés no centro da bóia & $\begin{array}{l}\mathrm{A}-\mathrm{B} \\
\mathrm{A} / \mathrm{B}\end{array}$ \\
\hline & & Colocar a bóia em uma das pernas & $\mathrm{A} / \mathrm{La}$ & $\begin{array}{l}\text { Girar em torno de si com os pés no centro da bóia, segurando } \\
\text { boneco Tikinho }\end{array}$ & $\mathrm{B} / \mathrm{A}$ \\
\hline
\end{tabular}




\begin{tabular}{|c|c|c|c|c|c|}
\hline Categoria de objetos $^{1}$ & $\mathbf{N}$ & Função igual à usual & Sujeitos $^{2}$ & Função diferente da usual & Sujeitos $^{2}$ \\
\hline & & Pular, segurando a bóia & $\mathrm{A} / \mathrm{La}$ & Jogar a bóia (para frente, para o chão) & $\begin{array}{l}\mathrm{A} / \mathrm{La} \\
\mathrm{Gu} / \mathrm{B}(3) \\
\mathrm{B} \text { imt } \mathrm{Gu} \\
\mathrm{B}-\mathrm{Gu} \\
\mathrm{Gu} / \mathrm{H} \\
\mathrm{H} \mathrm{imt} \mathrm{Gu} \\
\end{array}$ \\
\hline & & Por um pé no centro da bóia & $\mathrm{A} / \mathrm{La}$ & $\begin{array}{l}\text { Colocar um pé no centro de cada bóia (uma ao lado da outra) e } \\
\text { sentar-se sobre uma delas }\end{array}$ & $\mathrm{La} / \mathrm{A}$ \\
\hline & & Por os dois pés no centro da bóia & $\begin{array}{l}\mathrm{A} / \mathrm{La} \\
\mathrm{La} / \mathrm{A}\end{array}$ & $\begin{array}{l}\text { Pisar sobre a bóia, falando "oi, oi, ohi. Cuidado!", enquanto se } \\
\text { equilibra }\end{array}$ & $\mathrm{A} / \mathrm{La}$ \\
\hline & & $\begin{array}{l}\text { Deitar-se sobre a bóia e balançar com o corpo de um } \\
\text { lado para o outro, falando }\end{array}$ & $\mathrm{A} / \mathrm{La}$ & $\begin{array}{l}\text { Uma criança pisa sobre uma parte da bóia enquanto a outra segura } \\
\text { na outra parte }\end{array}$ & A-La \\
\hline & & Balançar a bóia, encostando-a no chão & $\mathrm{B} / \mathrm{Gu}$ & Pôr um pé sobre a bóia & $\mathrm{La} / \mathrm{A}$ \\
\hline & & $\begin{array}{l}\text { Deitar e depois se sentar sobre a bóia e balançar o corpo } \\
\text { de um lado para o outro }\end{array}$ & $\mathrm{Gu} / \mathrm{B}$ & $\begin{array}{l}\text { Girar em torno de si segurando a bóia na cintura repetindo "bóia, } \\
\text { bóia, bóia". Depois cai no chão }\end{array}$ & $\mathrm{A} / \mathrm{La}$ \\
\hline & & Deitar-se sobre a bóia, com a barriga para baixo & \begin{tabular}{|l}
$\mathrm{B} / \mathrm{Gu}$ \\
$\mathrm{S} / \mathrm{C}$ \\
$\mathrm{Gu} / \mathrm{Gi}$ \\
$\mathrm{Gi} \mathrm{imt}$ \\
$\mathrm{Gu}$ \\
\end{tabular} & Girar em torno de si segurando a bóia na cintura & La imt A \\
\hline & & $\begin{array}{l}\text { Correr com a bóia na cintura, deixando-a escorregar pelo } \\
\text { corpo }\end{array}$ & $\mathrm{Li} / \mathrm{B}$ & Girar em torno de si segurando a bóia na cintura e gritar "yes" & $\mathrm{A} / \mathrm{La}$ \\
\hline \multirow[t]{5}{*}{ Bóias de cintura (4.d) } & & $\begin{array}{l}\text { Caminhar e pular, segurando a bóia e vocalizando "éh, } \\
\text { éh-é, éh" }\end{array}$ & $\mathrm{C} / \mathrm{H}$ & Andar com a bóia nos pés & $\begin{array}{l}\mathrm{B} / \mathrm{Gu} \\
\mathrm{Gi} / \mathrm{Li}\end{array}$ \\
\hline & & $\begin{array}{l}\text { Andar pela sala, cantando, e segurando a bóia abaixo das } \\
\text { axilas }\end{array}$ & $\mathrm{Li} / \mathrm{C}$ & Engatinhar com joelhos no centro da bóia; fala "ai, ai" e "caî" & $\begin{array}{l}\mathrm{B} / \mathrm{Gu} \\
\mathrm{Gu} \text { imt B }\end{array}$ \\
\hline & & $\begin{array}{l}\text { Sentar-se sobre a bóia e balançar-se para frente e para } \\
\text { trás, vocalizando "chá, cháchá..." }\end{array}$ & $\mathrm{S} / \mathrm{C}$ & Deitar boneco sobre a bóia & $\begin{array}{l}\mathrm{H} / \mathrm{C} \\
\mathrm{C} \text { imt } \mathrm{H} \\
\mathrm{Gi} / \mathrm{Gu} \\
\mathrm{Gu} / \mathrm{H} \\
\mathrm{H} \text { imt } \mathrm{Gu}\end{array}$ \\
\hline & & $\begin{array}{l}\text { Correr em direção à bóia e deitar-se nela, de barriga para } \\
\text { baixo }\end{array}$ & $\mathrm{Gu} / \mathrm{Gi}$ & Empurrar bóia sobre o chão, como se ela fosse uma roda & $\begin{array}{l}\mathrm{H} / \mathrm{C} \\
\mathrm{Gu} / \mathrm{Gi} \\
\mathrm{Gi} \text { imt } \\
\mathrm{Gu}\end{array}$ \\
\hline & & $\begin{array}{l}\text { Pôr o festão no centro da bóia e deitar-se sobre eles, de } \\
\text { barriga para baixo }\end{array}$ & $\begin{array}{l}\mathrm{Gi} / \mathrm{Gu} \\
(2)\end{array}$ & Dar impulso na bóia e soltá-la, fazendo-a rodar para frente & $\mathrm{H} / \mathrm{C}$ \\
\hline
\end{tabular}




\begin{tabular}{|c|c|c|c|c|c|}
\hline Categoria de objetos $^{1}$ & $\mathbf{N}$ & Função igual à usual & Sujeitos $^{2}$ & Função diferente da usual & Sujeitos $^{2}$ \\
\hline & & Movimentar a bóia no ar & $\begin{array}{l}\mathrm{H} / \mathrm{Gu} \\
\mathrm{Gu} \text { imt } \mathrm{H}\end{array}$ & Pular e dançar segurando bóia no corpo & $\begin{array}{l}\mathrm{Li} / \mathrm{C} \\
\mathrm{C} \text { imt Li } \\
\mathrm{C}-\mathrm{Li}\end{array}$ \\
\hline & & Correr com a bóia na cintura & $\mathrm{Gi} / \mathrm{Li}$ & Chutar bóia & $\begin{array}{l}\mathrm{Li} / \mathrm{C} \\
\mathrm{S} / \mathrm{C} \\
\mathrm{C} / \mathrm{S} \\
\mathrm{S} / \mathrm{La}\end{array}$ \\
\hline & & Andar com a bóia na cintura, dizendo que vai à piscina & $\mathrm{Gi} / \mathrm{Li}$ & Lançar bóia para trás, com os dois braços, e vocalizar "iah" & \begin{tabular}{|l}
$\mathrm{S} / \mathrm{C}$ \\
$\mathrm{C}$ imt $\mathrm{S}$
\end{tabular} \\
\hline & & Deitar-se sobre a bóia, de costas & $\mathrm{La} / \mathrm{S}$ & Lançar a bóia para cima & \begin{tabular}{|l|}
$\mathrm{C} / \mathrm{S}$ \\
$\mathrm{La} / \mathrm{S}$ \\
$\mathrm{S}$ imt La \\
$\mathrm{S} / \mathrm{La}$ \\
\end{tabular} \\
\hline & & $\begin{array}{l}\text { Deitar-se no chão com a bóia sob a cabeça (como uma } \\
\text { almofada ou travesseiro) }\end{array}$ & $\mathrm{La} / \mathrm{S}$ & $\begin{array}{l}\text { Colocar uma bóia sobre a outra (sobre o chão), cobrí-las com feltro } \\
\text { e perguntar para a outra criança se ela sabia o que era aquilo. } \\
\text { Depois, descobre-as e diz que são bóias. }\end{array}$ & $\mathrm{Gi} / \mathrm{Gu}$ \\
\hline & & & & Brincar de vender bóias para a outra criança & $\mathrm{Gi} / \mathrm{Gu}$ \\
\hline & & & & $\begin{array}{l}\text { Girar em torno de si segurando a bóia na cintura e dizer que é uma } \\
\text { bailarina }\end{array}$ & $\mathrm{Gi} / \mathrm{Gu}$ \\
\hline & & & & Tentar sentar-se sobre bóia posicionada na vertical & Gu/Gi \\
\hline & & & & $\begin{array}{l}\text { Sentar-se sobre a bóia colocada na vertical e entre as pernas, como } \\
\text { se ela fosse um "cavalinho" }\end{array}$ & $\mathrm{Gu} / \mathrm{Gi}$ \\
\hline & & & & Bater a bóia na parede & $\mathrm{Gu} / \mathrm{H}$ \\
\hline & & & & Colocar a bóia sobre o feltro & $\begin{array}{l}\mathrm{H} / \mathrm{Gu} \\
\mathrm{Gu} \text { imt } \mathrm{H}\end{array}$ \\
\hline & & & & Passar boneco pelo centro da bóia & $\mathrm{H} / \mathrm{Gu}$ \\
\hline & & & & Ajoelhar-se sobre a bóia & $\begin{array}{l}\mathrm{La} / \mathrm{S}(2) \\
\mathrm{S} \text { imt La }\end{array}$ \\
\hline \multirow{4}{*}{ Bolas $(2 . i, 5 . d)$} & \multirow{4}{*}{8} & Jogar bola usando as mãos & $\begin{array}{l}\mathrm{C} / \mathrm{Gi} \\
\mathrm{H} / \mathrm{S}\end{array}$ & Segurar a bola (enrugada) com a boca e emitir sons & $\mathrm{A} / \mathrm{H}$ \\
\hline & & Chutar bola & $\begin{array}{l}\mathrm{Gu} / \mathrm{S} \\
\mathrm{S} / \mathrm{H} \\
\mathrm{H} / \mathrm{S} \\
\end{array}$ & & \\
\hline & & Trocar de bolas & $\mathrm{H}-\mathrm{S}$ & & \\
\hline & & Bater uma bola na outra & C/A & & \\
\hline Boneca(o)s (4.i, 5.i) & 42 & $\begin{array}{l}\text { Criança diz que "o neném tá chorando" e vai buscá-lo na } \\
\text { caixa. Carrega-o, no colo, diz que ele está pesado }\end{array}$ & $\mathrm{B} / \mathrm{A}$ & Colocar boneco sobre a cabeça & $\mathrm{Li} / \mathrm{C}$ \\
\hline
\end{tabular}




\begin{tabular}{|c|c|c|c|c|c|}
\hline Categoria de objetos $^{1}$ & $\mathbf{N}$ & Função igual à usual & Sujeitos $^{2}$ & Função diferente da usual & Sujeitos $^{2}$ \\
\hline & & $\begin{array}{l}\text { Carregar boneco no colo, como se fosse um bebê: } \\
\text { acaricia-o, dança e canta }\end{array}$ & $\mathrm{Li} / \mathrm{A}$ & Referir-se aos bonecos deitados lado a lado como "mamãe e papai" & $\mathrm{B} / \mathrm{Li}$ \\
\hline & & $\begin{array}{l}\text { Colocar boneco em pé sobre o chão, dizendo “vamo } \\
\text { pulá" }\end{array}$ & $\mathrm{Li} / \mathrm{A}$ & Segurar boneca em pé sobre a carroceria do caminhão & $\mathrm{A} / \mathrm{Gi}$ \\
\hline & & $\begin{array}{l}\text { Colocar bebê para dormir: põe saco juta dentro da caixa, } \\
\text { boneco deitado sobre ele e cobre-o com feltro; faz } \\
\text { "schiii" c/ dedo indicador (para pedir silêncio) }\end{array}$ & $\mathrm{Li} / \mathrm{A}$ & Falar olhando para a boneca & $\mathrm{A} / \mathrm{Gi}$ \\
\hline & & $\begin{array}{l}\text { Colocar bebê para dormir: põe saco juta sobre o chão, } \\
\text { boneco deitado sobre ele e cobre-o com feltro. Diz "o } \\
\text { neném tá dormindo; ñ faz barulho" }\end{array}$ & $\mathrm{Li} / \mathrm{A}$ & Falar com a boneca & $\mathrm{La} / \mathrm{Gi}$ \\
\hline & & $\begin{array}{l}\text { Colocar bebê para dormir: põe saco juta sobre o chão, } \\
\text { boneco deitado sobre ele e cobre-o com feltro }\end{array}$ & $\mathrm{Li} / \mathrm{A}$ & Tirar os membros e a cabeça da boneca & $\mathrm{Gi} / \mathrm{La}$ \\
\hline & & Abraçar boneco & $\begin{array}{l}\mathrm{A} / \mathrm{La} \\
\mathrm{Li} / \mathrm{C} \\
\end{array}$ & & \\
\hline & & Chamar boneco(a) de "nenê" ou "neném" & $\begin{array}{l}\mathrm{B} / \mathrm{A} \\
\mathrm{B} / \mathrm{Gu} \\
\mathrm{Gu} / \mathrm{Gi} \\
\mathrm{Li} / \mathrm{Gi} \\
\mathrm{Gi} / \mathrm{Li} \\
\mathrm{Gi} / \mathrm{C} \\
\mathrm{C} / \mathrm{Gi}(2) \\
\mathrm{Gi} / \mathrm{La}\end{array}$ & & \\
\hline & & Colocar bonecos dentro das caixas para eles dormirem & $\mathrm{B} / \mathrm{Gu}$ & & \\
\hline & & $\begin{array}{l}\text { Colocar sacos juta dentro das caixas e deitar os bonecos } \\
\text { sobre eles }\end{array}$ & $\mathrm{B} / \mathrm{Li}$ & & \\
\hline & & $\begin{array}{l}\text { Estender feltro no chão; colocar saco juta ao lado do } \\
\text { feltro e um boneco sobre cada. Tirar o boneco do feltro e } \\
\text { colocá-lo sobre o saco juta }\end{array}$ & $\mathrm{B} / \mathrm{Li}$ & & \\
\hline & & Ninar boneco(s) & $\begin{array}{l}\mathrm{B}-\mathrm{Li}(2) \\
\mathrm{Gu} / \mathrm{Gi}\end{array}$ & & \\
\hline & & Acariciar boneco(s) & B-Li & & \\
\hline & & Beijar boneco(s) & B-Li & & \\
\hline & & Colocar boneco sobre feltro estendido sobre o chão & $\begin{array}{l}\mathrm{Gu} / \mathrm{H} \\
\mathrm{H} \mathrm{imt} \mathrm{Gu}\end{array}$ & & \\
\hline \multirow[t]{2}{*}{ Boneca(o)s (4.i, 5.i) } & & Carregar dois bonecos no colo & $\mathrm{Li} / \mathrm{Gi}$ & & \\
\hline & & Embrulhar boneco com feltro(s) & $\begin{array}{l}\mathrm{Gi} / \mathrm{Li} \\
\mathrm{S} / \mathrm{La} \\
\end{array}$ & & \\
\hline
\end{tabular}




\begin{tabular}{|c|c|c|c|c|c|}
\hline Categoria de objetos $^{1}$ & $\mathbf{N}$ & Função igual à usual & Sujeitos $^{2}$ & Função diferente da usual & Sujeitos $^{2}$ \\
\hline & & Carregar a boneca no colo & $\begin{array}{l}\text { A/Gi (2) } \\
\text { A/Gu }\end{array}$ & & \\
\hline & & $\begin{array}{l}\text { Bater nas costas da boneca, como se a fizesse arrotar ou } \\
\text { a repreendesse }\end{array}$ & $\mathrm{A} / \mathrm{Gu}$ & & \\
\hline & & Deitar boneca sobre o chão & $\mathrm{La} / \mathrm{Gi}$ & & \\
\hline & & Tentar fazer a boneca andar sobre o chão & Gi/La & & \\
\hline \multirow{4}{*}{$\begin{array}{l}\text { Bonecos pequenos } \\
\text { articulados (6.i) }\end{array}$} & \multirow{4}{*}{4} & Segurar bonequinha pelos braços e balançá-la & $\mathrm{A} / \mathrm{La}$ & & \\
\hline & & Oferecer bonequinho para outra criança & $\mathrm{La} / \mathrm{S}$ & & \\
\hline & & $\begin{array}{l}\text { Cada criança segura um bonequinho e as duas brincam } \\
\text { como se eles estivessem conversando }\end{array}$ & La-S & & \\
\hline & & Fazer os bonequinhos beijarem-se & La-S & & \\
\hline \multirow[t]{9}{*}{$\begin{array}{l}\text { Caixas de papelão (7.i, } \\
\text { 7.d) }\end{array}$} & \multirow[t]{9}{*}{49} & Entrar na caixa (cada criança numa caixa) & $\begin{array}{l}\text { A-B } \\
\text { A-Li } \\
\text { A-La }\end{array}$ & $\begin{array}{l}\text { Colocar um boneco Tikinho em cada caixa e, depois, dizer que vai } \\
\text { dar um passeio e empurrar as caixas para o outro canto da sala, } \\
\text { como se fossem carrinhos de bebê }\end{array}$ & $\mathrm{B} / \mathrm{A}$ \\
\hline & & Pular dentro da caixa & $\begin{array}{l}\mathrm{A} / \mathrm{B} \\
\mathrm{B} \text { imt A }\end{array}$ & $\begin{array}{l}\text { Colocar festão e bóia dentro da caixa e fechar as suas abas. Após } \\
\text { fechá-la, deita-se de barriga sobre a caixa e diz "iéh, conseguimos" }\end{array}$ & $\mathrm{A} / \mathrm{La}$ \\
\hline & & Inclinar a caixa com outra criança dentro dela & $\mathrm{B} / \mathrm{A}$ & $\begin{array}{l}\text { Duas crianças entram numa mesma caixa e sentam-se. Uma criança } \\
\text { fala para a outra "a gente tamos presa" }\end{array}$ & $\begin{array}{l}\mathrm{A} / \mathrm{Li} \\
\mathrm{Li} \text { imt A }\end{array}$ \\
\hline & & $\begin{array}{l}\text { Recostar-se com as pernas para cima e os pés sobre os } \\
\text { bordos da caixa }\end{array}$ & $\begin{array}{l}\mathrm{A} / \mathrm{Li} \\
\mathrm{Li} \text { imt A }\end{array}$ & Referir-se à caixa como sendo uma cama & $\mathrm{B} / \mathrm{Gu}$ \\
\hline & & Trocar de caixas & A-Li & Jogar a caixa & $\mathrm{Li} / \mathrm{C}(2)$ \\
\hline & & Colocar boneco dentro da caixa e fechá-la & $\mathrm{B} / \mathrm{Gu}$ & Colocar a cabeça dentro da caixa virada com o fundo para o teto & $\mathrm{Li} / \mathrm{C}(2)$ \\
\hline & & Empurrar caixas pela sala & $\mathrm{B} / \mathrm{Li}$ & $\begin{array}{l}\text { Brincar de esconder dentro da caixa e aparecer (tirando parte do } \\
\text { corpo para fora) }\end{array}$ & C-S \\
\hline & & Colocar boneco dentro da caixa & \begin{tabular}{|l|}
$\mathrm{Gu}$ imt B \\
$\mathrm{Li} / \mathrm{C}$ \\
$\mathrm{S} / \mathrm{La}$ \\
\end{tabular} & Brincar de esconde-esconde (uma criança procura a outra) & C-S \\
\hline & & Colocar / guardar / jogar objetos dentro da caixa & $\begin{array}{l}\mathrm{C} / \mathrm{H}(2) \\
\mathrm{C} / \mathrm{Li}(2) \\
\mathrm{Li} / \mathrm{C} \\
\mathrm{C} / \mathrm{S} \\
\mathrm{Gi} / \mathrm{Gu} \\
\mathrm{A} / \mathrm{Gi} \\
\mathrm{Gi} / \mathrm{A}(2) \\
\mathrm{Gi} / \mathrm{H}(2) \\
\mathrm{H} \text { imt Gi } \\
(2)\end{array}$ & Colocar objetos dentro da caixa e entrar nela & $\mathrm{Li} / \mathrm{Gi}$ \\
\hline
\end{tabular}




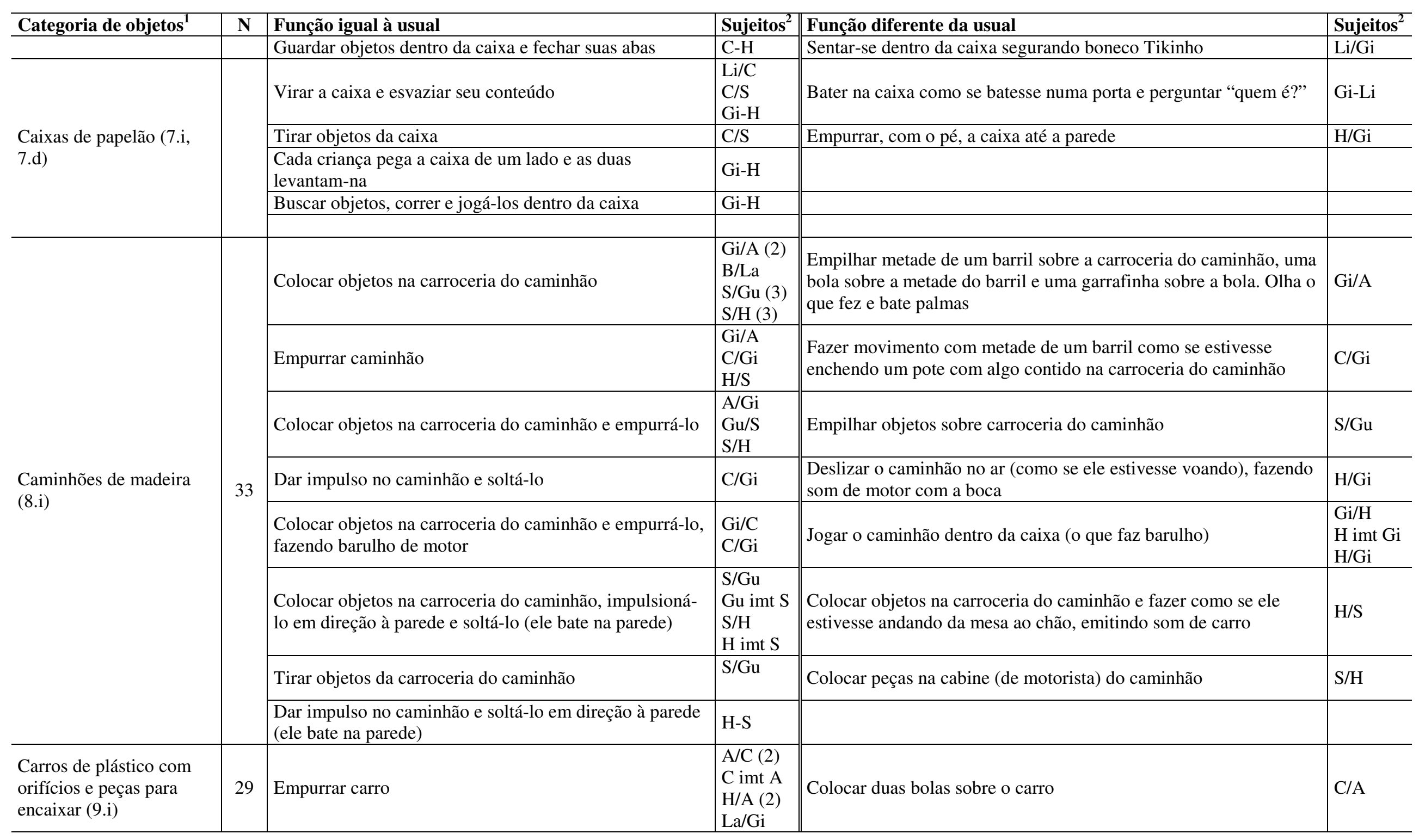




\begin{tabular}{|c|c|c|c|c|c|}
\hline Categoria de objetos $^{1}$ & $\mathbf{N}$ & Função igual à usual & Sujeitos $^{2}$ & Função diferente da usual & Sujeitos $^{2}$ \\
\hline & & $\begin{array}{l}\text { Encaixar / desencaixar peças pelos orifícios do(s) } \\
\text { carro(s) }\end{array}$ & \begin{tabular}{l|}
$\mathrm{A}-\mathrm{C}$ \\
$\mathrm{A} / \mathrm{H}$ \\
$\mathrm{La} / \mathrm{Gi}$
\end{tabular} & Tentar colocar a bola nos orifícios do carro (ela não cabe) & $\begin{array}{l}\mathrm{Gu} / \mathrm{A} \\
\mathrm{H} / \mathrm{A} \\
\mathrm{A} / \mathrm{H}(2)\end{array}$ \\
\hline & & $\begin{array}{l}\text { Virar o carro e deixar as peças caírem pela porta de trás } \\
\text { dele }\end{array}$ & $\mathrm{H} / \mathrm{A}$ & $\begin{array}{l}\text { Colocar várias peças do carro sobre o próprio braço dobrado, como } \\
\text { se estivesse testando o quanto consegue carregar }\end{array}$ & $\mathrm{A} / \mathrm{H}$ \\
\hline \multirow{5}{*}{$\begin{array}{l}\text { Carros de plástico com } \\
\text { orifícios e peças para } \\
\text { encaixar (9.i) }\end{array}$} & & Colocar objetos dentro do carro pela porta de trás dele & $\begin{array}{l}\mathrm{H} / \mathrm{A} \\
\mathrm{A} \text { imt H } \\
\mathrm{Gi} / \mathrm{La}\end{array}$ & Empurrar carro, vocalizando "piui, tic, tic, tic..." & $\begin{array}{l}\mathrm{La} / \mathrm{Gi} \\
\mathrm{Gi} \text { imt } \\
\mathrm{La}\end{array}$ \\
\hline & & $\begin{array}{l}\text { Tirar objetos que estavam dentro do carro pela porta de } \\
\text { trás dele }\end{array}$ & $\begin{array}{l}\mathrm{H} / \mathrm{A}(2) \\
\mathrm{A} / \mathrm{H} \\
\mathrm{La} / \mathrm{Gi}\end{array}$ & A criança deita-se e fica movimentando o carro sobre o chão & $\mathrm{La} / \mathrm{Gi}$ \\
\hline & & $\begin{array}{l}\text { Colocar objetos dentro do carro e empurrá-lo, raspando o } \\
\text { pára-choque traseiro no chão (o que faz barulho) }\end{array}$ & $\mathrm{H} / \mathrm{A}$ & & \\
\hline & & Colocar objetos dentro do carro e empurrá-lo & $\mathrm{Gi} / \mathrm{La}$ & & \\
\hline & & $\begin{array}{l}\text { Dar impulso no carro e soltá-lo em direção a outra } \\
\text { criança, que o pega }\end{array}$ & $\mathrm{La} / \mathrm{Gi}$ & & \\
\hline \multirow[t]{5}{*}{$\begin{array}{l}\text { Casinhas com orifícios e } \\
\text { peças para encaixar } \\
\text { (13.d) }\end{array}$} & \multirow[t]{5}{*}{40} & Tirar / colocar peças da casinha pela porta & $\begin{array}{l}\mathrm{A} / \mathrm{La} \\
\mathrm{C} / \mathrm{H} \\
\mathrm{C} / \mathrm{S} \\
\end{array}$ & Colocar objetos dentro da casinha & $\begin{array}{l}\mathrm{A} / \mathrm{Li} \\
\mathrm{A} / \mathrm{La} \\
\mathrm{C} / \mathrm{Li}\end{array}$ \\
\hline & & Encaixar peças nos orifícios da casinha & $\begin{array}{l}\mathrm{Gu} / \mathrm{B} \\
\mathrm{Li} / \mathrm{B} \\
\mathrm{C} / \mathrm{Li}(2) \\
\mathrm{H} / \mathrm{Gu} \\
\mathrm{La} / \mathrm{S} \\
\mathrm{S} / \mathrm{La}\end{array}$ & Jogar casinha e/ou suas peças no chão & $\begin{array}{l}\mathrm{B} / \mathrm{Gu}(2) \\
\mathrm{La} / \mathrm{S}\end{array}$ \\
\hline & & Colocar bonequinhos dentro da casinha & $\begin{array}{l}\mathrm{Li} / \mathrm{B} \\
\mathrm{Gi} / \mathrm{Li}\end{array}$ & Jogar casinha e/ou suas peças na outra criança & $\mathrm{B} / \mathrm{Gu}$ \\
\hline & & Girar (rosquear / desrosquear) a chaminé da casinha & $\begin{array}{l}\mathrm{H} / \mathrm{C} \\
\mathrm{C} \mathrm{imt} \mathrm{H} \\
\mathrm{C} / \mathrm{Li} \\
\mathrm{S} / \mathrm{C}(2) \\
\mathrm{C} / \mathrm{S}(2) \\
\mathrm{Gu} / \mathrm{Gi} \\
\mathrm{H} / \mathrm{Gu}(2) \\
\mathrm{Gu} \mathrm{imt} \mathrm{H}\end{array}$ & Bater peça da casinha na porta & $\mathrm{Gu} / \mathrm{B}$ \\
\hline & & Abrir / fechar a porta da casinha & $\mathrm{C} / \mathrm{Li}$ & Fingir que casinha é um mercado & $\mathrm{C}-\mathrm{Li}$ \\
\hline
\end{tabular}




\begin{tabular}{|c|c|c|c|c|c|}
\hline Categoria de objetos $^{1}$ & $\mathbf{N}$ & Função igual à usual & Sujeitos $^{2}$ & Função diferente da usual & Sujeitos $^{2}$ \\
\hline & & Tirar / colocar peças da casinha pelo buraco da chaminé & $\begin{array}{l}\mathrm{S} / \mathrm{C} \\
\mathrm{C} / \mathrm{S}(2) \\
\end{array}$ & Usar peças como se fossem os produtos comprados no mercado & $\mathrm{C}-\mathrm{Li}$ \\
\hline & & Virar a casinha (para tirar peças) & $\mathrm{H} / \mathrm{Gu}$ & Girar a casinha sobre a mesa (como se estivesse procurando algo) & $\mathrm{Gu} / \mathrm{H}$ \\
\hline & & & & $\begin{array}{l}\text { Bater peça da casinha na barriga do boneco (brincadeira de } \\
\text { médico?) }\end{array}$ & $\mathrm{Gu} / \mathrm{H}$ \\
\hline Colares (10.i) & 13 & Colocar colar no próprio pescoço & $\begin{array}{l}\mathrm{A} / \mathrm{C}(2) \\
\mathrm{A} / \mathrm{Gu} \\
\mathrm{H} / \mathrm{A} \\
\mathrm{A} / \mathrm{H} \\
\end{array}$ & Deixar colar escorregar pelo corpo (do pescoço ao chão) & $\mathrm{A} / \mathrm{C}$ \\
\hline \multirow{3}{*}{ Colares (10.i) } & & Esticar colar & $\mathrm{A} / \mathrm{C}$ & $\begin{array}{l}\text { Colocar um colar sobre o chão ao redor de uma bola (a bola fica no } \\
\text { espaço interno limitado pelo colar) e o outro ao lado do primeiro }\end{array}$ & $\mathrm{C} / \mathrm{A}$ \\
\hline & & Colocar colar no pescoço de outra criança & $\begin{array}{l}\mathrm{A} / \mathrm{Gu} \\
\mathrm{A} / \mathrm{H}(2)\end{array}$ & $\begin{array}{l}\text { Colocar uma bola no espaço interno limitado pelo colar que estava } \\
\text { sobre o chão }\end{array}$ & $\mathrm{C} / \mathrm{A}$ \\
\hline & & Movimentar o colar (o que faz barulho) & $\mathrm{A} / \mathrm{H}$ & & \\
\hline \multirow[t]{8}{*}{ Fantoches (14.d, 15.d) } & \multirow[t]{8}{*}{27} & $\begin{array}{l}\text { Por a mão dentro do pato e apertar seu bico (ativando a } \\
\text { buzina e a língua de sogra) }\end{array}$ & $\begin{array}{l}\text { A/Gi } \\
\text { A-Gi } \\
\text { Gi/A }\end{array}$ & $\begin{array}{l}\text { Apertar o bico do pato por fora do fantoche (ativando a buzina e a } \\
\text { língua de sogra) }\end{array}$ & $\mathrm{Gi} / \mathrm{A}$ \\
\hline & & $\begin{array}{l}\text { Andar atrás de outra criança apertando o bico do pato } \\
\text { perto dela }\end{array}$ & $\mathrm{Gi} / \mathrm{A}$ & Manipular a língua de sogra do pato & $\mathrm{Gi} / \mathrm{A}$ \\
\hline & & Pôr a mão dentro do fantoche & $\mathrm{C} / \mathrm{A}$ & Tirar / colocar o bico do / no fantoche & $\begin{array}{l}\mathrm{A} / \mathrm{Gi} \\
\mathrm{Gi} \text { imt A } \\
\mathrm{Gi} / \mathrm{A} \\
\mathrm{S} / \mathrm{Gu} \\
\mathrm{H} / \mathrm{S} \\
\mathrm{S} \text { imt H }\end{array}$ \\
\hline & & & & $\begin{array}{l}\text { Apertar bico retirado do fantoche (ativando a buzina e a língua de } \\
\text { sogra) }\end{array}$ & $\begin{array}{l}\mathrm{S} / \mathrm{Gu} \\
\mathrm{S} / \mathrm{H} \\
\end{array}$ \\
\hline & & & & Tirar / colocar a língua de sogra do bico do fantoche & $\mathrm{S} / \mathrm{Gu}$ \\
\hline & & & & $\begin{array}{l}\text { Bater com bico do pato (fora do fantoche) em peças do módulo } \\
\text { geométrico }\end{array}$ & $\mathrm{Gu} / \mathrm{S}$ \\
\hline & & & & $\begin{array}{l}\text { Apertar o bico do pato (fora do fantoche) em direção à (perto da) } \\
\text { boneca }\end{array}$ & $\begin{array}{l}\mathrm{Gi} / \mathrm{H}(3) \\
\mathrm{H} \text { imt Gi } \\
(3)\end{array}$ \\
\hline & & & & $\begin{array}{l}\text { Apertar o bico do pato (fora do fantoche) em direção à (perto da) } \\
\text { metade de um barril }\end{array}$ & \begin{tabular}{|l|}
$\mathrm{Gi} / \mathrm{H}$ \\
$\mathrm{H} \mathrm{imt} \mathrm{Gi}$
\end{tabular} \\
\hline
\end{tabular}




\begin{tabular}{|c|c|c|c|c|c|}
\hline Categoria de objetos $^{1}$ & $\mathbf{N}$ & Função igual à usual & Sujeitos $^{2}$ & Função diferente da usual & Sujeitos $^{2}$ \\
\hline & & & & $\begin{array}{l}\text { Brincar com o bico (fora do fantoche) como se ele fosse uma arma } \\
\text { ou aeronave (fazendo barulho com a boca), atirando nos caminhões } \\
\text { de perto }\end{array}$ & $\mathrm{H} / \mathrm{S}$ \\
\hline & & & & Tentar pôr o fantoche na cabeça & $\mathrm{C} / \mathrm{A}$ \\
\hline \multirow{5}{*}{$\begin{array}{l}\text { Feltros, lenços (16.d, } \\
\text { 19.d) }\end{array}$} & \multirow{5}{*}{13} & $\begin{array}{l}\text { Cobrir bonecos com feltro, deixando as cabeças para } \\
\text { fora, e deitar-se ao lado deles e cobrir-se também }\end{array}$ & $\mathrm{B} / \mathrm{Li}$ & Chamar o feltro de "saco" & $\mathrm{Gi} / \mathrm{Gu}$ \\
\hline & & $\begin{array}{l}\text { Sentar-se ao lado dos bonecos e cobrir as pernas com o } \\
\text { feltro }\end{array}$ & $\mathrm{B} / \mathrm{Li}$ & Cobrir bóia com feltro & $\begin{array}{l}\text { Gi/Gu } \\
\text { Gu imt } \\
\text { Gi }\end{array}$ \\
\hline & & Cobrir boneco com feltro & $\begin{array}{l}\text { Gu/Gi } \\
(3)\end{array}$ & Chamar o feltro de "toalha" & $\begin{array}{l}\mathrm{Gi} / \mathrm{Gu} \\
\mathrm{Gi} / \mathrm{Li} \\
\end{array}$ \\
\hline & & Dobrar / desdobrar lenços & $\mathrm{A} / \mathrm{Gu}$ & Arrastar o feltro com bóia e boneco sobre ele & $\mathrm{H} / \mathrm{Gu}$ \\
\hline & & Estender lenço sobre o chão e colocar boneca sobre ele & $\mathrm{A} / \mathrm{Gu}$ & & \\
\hline \multirow{9}{*}{ Festões (12.i) } & \multirow{9}{*}{20} & Correr, segurando o festão, parar e movimentá-lo no ar & $\mathrm{A} / \mathrm{Li}$ & Colocar festão sobre a bóia & $\begin{array}{l}\mathrm{La} / \mathrm{A}(2) \\
\mathrm{A} \mathrm{imt} \mathrm{La} \\
\mathrm{Gi} / \mathrm{Gu}\end{array}$ \\
\hline & & Movimentar festão no ar e fazer som de "uuuh" & A-Li & Encostar festão na boca & $\mathrm{A} / \mathrm{La}$ \\
\hline & & Movimentar festão no ar & $\begin{array}{l}\mathrm{La} / \mathrm{A} \\
\mathrm{Li} / \mathrm{B} \\
\mathrm{C} / \mathrm{H}\end{array}$ & Encostar festão na bóia & $\mathrm{Li} / \mathrm{B}$ \\
\hline & & Jogar festão em outra criança & $\mathrm{Gu} / \mathrm{B}$ & $\begin{array}{l}\text { Colocar festão em volta do pescoço e dizer que ele é uma roupa } \\
\text { (cachecol?) }\end{array}$ & $\mathrm{B} / \mathrm{Li}$ \\
\hline & & Dizer que o festão é de Natal & $\begin{array}{l}\mathrm{Li} / \mathrm{B} \\
\mathrm{Li} / \mathrm{C}\end{array}$ & Dizer que o festão é um sorvete & $\mathrm{C} / \mathrm{Li}$ \\
\hline & & Esticar o festão & $\mathrm{Li} / \mathrm{B}$ & & \\
\hline & & Rodar em torno de si segurando o festão & $\mathrm{Li} / \mathrm{C}$ & & \\
\hline & & $\begin{array}{l}\text { Rodar em torno de si segurando festão numa mão e bolsa } \\
\text { na outra }\end{array}$ & $\mathrm{C} / \mathrm{Li}$ & & \\
\hline & & Amassar o festão & $\mathrm{C} / \mathrm{Li}$ & & \\
\hline \multirow{2}{*}{$\begin{array}{l}\text { Garrafas pet pequenas } \\
\text { preenchidas com água, } \\
\text { detergente, miçangas e } \\
\text { estrelinhas (17.d) }\end{array}$} & \multirow[t]{2}{*}{29} & $\begin{array}{l}\text { Fingir que verte líquido de uma garrafinha para a outra, } \\
\text { fazendo barulhinho com a boca }\end{array}$ & Gi/A & Chamar garrafinha de "suco" & $\begin{array}{l}\mathrm{Gi} / \mathrm{A} \\
\mathrm{C} / \mathrm{Gi} \\
\mathrm{Gi} / \mathrm{C}\end{array}$ \\
\hline & & Chacoalhar garrafinha & $\begin{array}{l}\text { B/La } \\
\text { C/Gi (2) } \\
\text { S/Gu } \\
\text { Gu/S } \\
\mathrm{H}-\mathrm{S} \\
\end{array}$ & $\begin{array}{l}\text { Virar garrafinha sobre metade de um barril (como se fosse copo) e } \\
\text { dizer que "é suco para o nenê" }\end{array}$ & $\mathrm{C} / \mathrm{Gi}$ \\
\hline
\end{tabular}




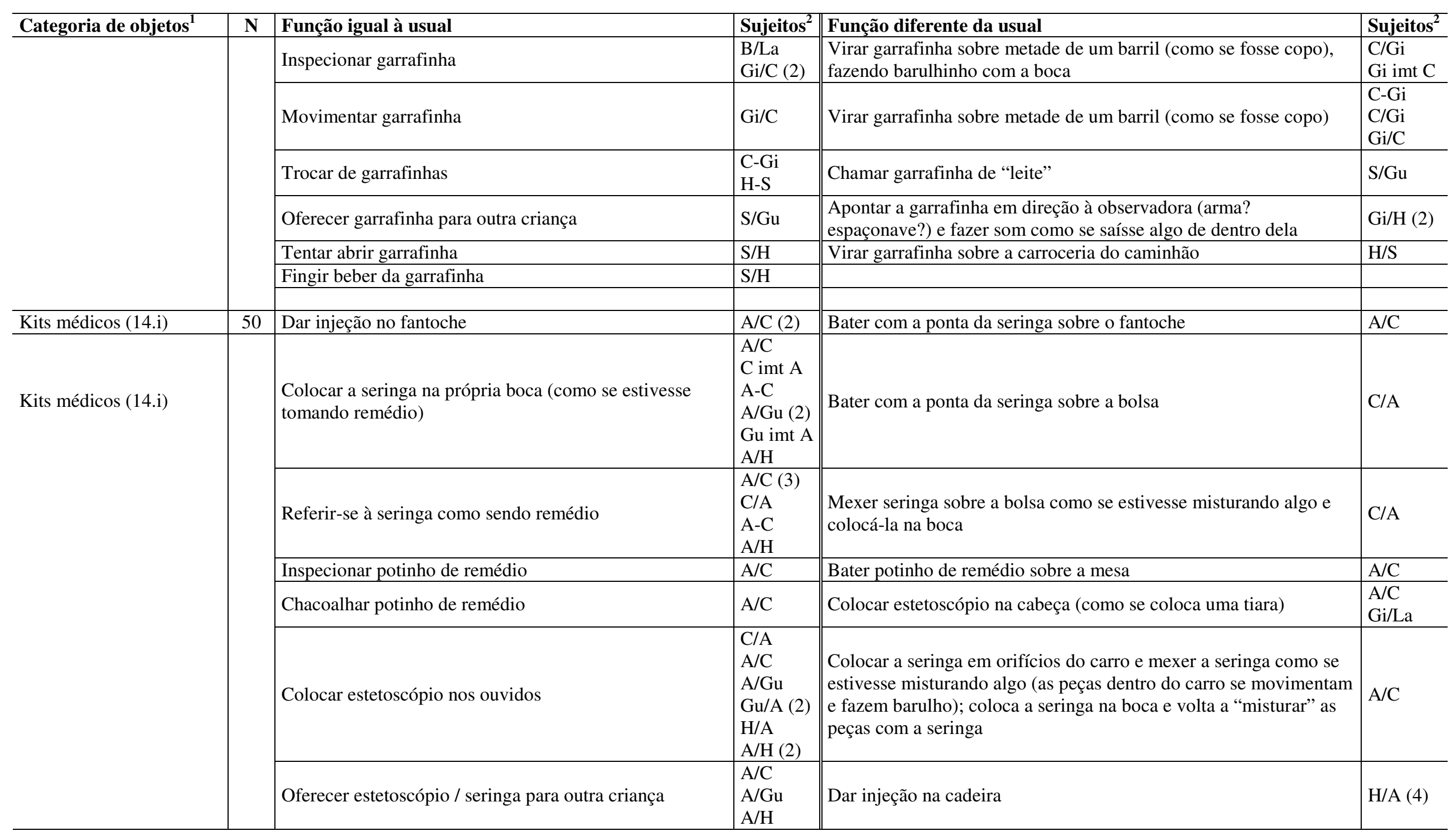




\begin{tabular}{|c|c|c|c|c|c|}
\hline Categoria de objetos $^{1}$ & $\mathbf{N}$ & Função igual à usual & Sujeitos $^{2}$ & Função diferente da usual & Sujeitos $^{2}$ \\
\hline & & $\begin{array}{l}\text { Colocar a seringa na boca de outra criança (como se } \\
\text { estivesse dando remédio para ela) }\end{array}$ & $\begin{array}{l}\mathrm{H} / \mathrm{A}(4) \\
\mathrm{Gi} / \mathrm{La}\end{array}$ & $\begin{array}{l}\text { Colocar a seringa em orifícios do carro e mexer a seringa como se } \\
\text { estivesse misturando algo, deixa-a cair dentro do carro, recolhe-a e } \\
\text { coloca-a na boca }\end{array}$ & $\mathrm{A} / \mathrm{H}$ \\
\hline & & $\begin{array}{l}\text { Encostar estetoscópio no corpo de outra criança e } \\
\text { "auscutá-la" }\end{array}$ & $\begin{array}{l}\mathrm{H} / \mathrm{A}(2) \\
\mathrm{Gi} / \mathrm{La} \\
\end{array}$ & $\begin{array}{l}\text { Pegar seringa e apoiar sua ponta sobre o lenço, dizendo que é para } \\
\text { pegar suco }\end{array}$ & $\mathrm{La} / \mathrm{Gi}$ \\
\hline & & Dar injeção em outra criança & $\mathrm{H} / \mathrm{A}$ & & \\
\hline Mesas e cadeiras (da sala) & 2 & & & Pôr os pés dentro da caixa e tentar subir sobre a mesa & \begin{tabular}{|l|l|} 
S/C \\
$\mathrm{C}$ imt S
\end{tabular} \\
\hline \multirow{4}{*}{$\begin{array}{l}\text { Módulos geométricos de } \\
\text { madeira (16.i) }\end{array}$} & \multirow{4}{*}{21} & $\begin{array}{l}\text { Encaixar / desencaixar peças nos / dos pinos da base do } \\
\text { módulo geométrico }\end{array}$ & \begin{tabular}{|l|} 
B-La \\
C/Gi (3) \\
Gi/C (2) \\
S/Gu \\
$\mathrm{H} / \mathrm{S}$ \\
$\mathrm{S} / \mathrm{H}$ \\
\end{tabular} & $\begin{array}{l}\text { Colocar garrafinha entre dois pinos do módulo geométrico (sem as } \\
\text { peças) }\end{array}$ & Gi/A (2) \\
\hline & & Empilhar peças do módulo geométrico & $\mathrm{S} / \mathrm{Gu}$ & Empurrar a base do módulo geométrico & $\mathrm{Gi} / \mathrm{A}$ \\
\hline & & $\begin{array}{l}\text { Empilhar peças do módulo geométrico sobre a carroceria } \\
\text { do caminhão }\end{array}$ & $\mathrm{S} / \mathrm{Gu}$ & Levantar a base do módulo geométrico no ar & $\mathrm{Gi} / \mathrm{A}$ \\
\hline & & $\begin{array}{l}\text { Desencaixar peças dos pinos da base e separá-las de } \\
\text { acordo com suas formas (círculo, quadrado, retângulo, } \\
\text { triângulo) }\end{array}$ & $\mathrm{Gi} / \mathrm{H}$ & Jogar uma peça circular, rodando-a, como roda, no chão & $\mathrm{C} / \mathrm{Gi}$ \\
\hline \multirow{3}{*}{$\begin{array}{l}\text { Módulos geométricos de } \\
\text { madeira (16.i) }\end{array}$} & & $\begin{array}{l}\text { Encaixar peças nos pinos da base, colocando-as de } \\
\text { acordo com suas formas (círculo, quadrado, retângulo, } \\
\text { triângulo) e tamanhos (da maior para a menor) }\end{array}$ & $\mathrm{Gi} / \mathrm{H}$ & $\begin{array}{l}\text { Desencaixar peças uma a uma dos pinos da base e colocá-las com } \\
\text { força sobre a mesa (a outra criança, que observa, ri) }\end{array}$ & $\mathrm{Gi} / \mathrm{H}$ \\
\hline & & & & $\begin{array}{l}\text { Tentar equilibrar módulo invertido, com os pinos para baixo e a } \\
\text { base para cima }\end{array}$ & $\mathrm{H} / \mathrm{S}$ \\
\hline & & & & Encaixar metades dos barris nos pinos do módulo geométrico & $\mathrm{H} / \mathrm{S}$ \\
\hline \multirow{6}{*}{ Peças de madeira (18.i) } & \multirow{6}{*}{9} & & & $\begin{array}{l}\text { Esfregar peças de madeira no corpo de outra criança, em } \\
\text { brincadeira de médico }\end{array}$ & $\mathrm{Gi} / \mathrm{La}(4)$ \\
\hline & & & & Referir-se à peça como "sabonete" & $\mathrm{La} / \mathrm{Gi}$ \\
\hline & & & & Referir-se à peça como "remédio para dor de cabeça" & $\mathrm{La} / \mathrm{Gi}$ \\
\hline & & & & Referir-se à peça como "leite" & $\mathrm{Gi} / \mathrm{La}$ \\
\hline & & & & Referir-se à peça como “xampu” & $\mathrm{La} / \mathrm{Gi}$ \\
\hline & & & & $\begin{array}{l}\text { Virar peça sobre a cabeça de outra criança, como se estivesse } \\
\text { colocando xampu }\end{array}$ & $\mathrm{Gi} / \mathrm{La}$ \\
\hline Sacos de juta (21.i) & 3 & Colocar objetos dentro dele & $\begin{array}{l}\mathrm{La} / \mathrm{S} \\
\mathrm{S} \text { imt La }\end{array}$ & Colocá-lo no chão e sentar-se sobre ele & $\mathrm{B} / \mathrm{Li}$ \\
\hline
\end{tabular}




\begin{tabular}{|c|c|c|c|c|c|}
\hline Categoria de objetos $^{1}$ & $\mathbf{N}$ & Função igual à usual & Sujeitos $^{2}$ & Função diferente da usual & Sujeitos $^{2}$ \\
\hline \multirow{5}{*}{$\begin{array}{l}\text { Trem e caminhão de } \\
\text { plástico com peças de } \\
\text { encaixar (tipo quebra- } \\
\text { cabeças - 24.d) }\end{array}$} & \multirow{5}{*}{45} & Encaixar/desencaixar peças & $\begin{array}{l}\mathrm{A} / \mathrm{B} \\
\mathrm{Li} / \mathrm{A} \\
\mathrm{La} / \mathrm{A}(2) \\
\mathrm{A}-\mathrm{La} \\
\mathrm{C} / \mathrm{H} \\
\mathrm{C}-\mathrm{S}(2) \\
\mathrm{Gi} / \mathrm{Gu} \\
\mathrm{H} / \mathrm{Gu} \\
\mathrm{Gi} / \mathrm{Li} \\
\mathrm{La} / \mathrm{S}\end{array}$ & Jogá-lo no chão & $\begin{array}{l}\mathrm{B} / \mathrm{Gu}(5) \\
\mathrm{Gu} \text { imt B } \\
(2)\end{array}$ \\
\hline & & $\begin{array}{l}\text { Encaixar peças, enquanto canta a música do "boi da cara } \\
\text { preta" }\end{array}$ & $\mathrm{A} / \mathrm{Li}(2)$ & Movimentá-lo(s) no ar & $\begin{array}{l}\mathrm{C} / \mathrm{H} \\
\mathrm{H} \text { imt C }\end{array}$ \\
\hline & & Levantar caçamba do caminhão (talvez tentando tirá-la) & $\mathrm{La} / \mathrm{A}$ & $\begin{array}{l}\text { Uma criança passa peça por peça para outra, batendo-as, antes, na } \\
\text { mesa. }\end{array}$ & $\mathrm{C}-\mathrm{Li}$ \\
\hline & & $\begin{array}{l}\text { Encaixar peças e caçamba do caminhão, enquanto } \\
\text { cantarola }\end{array}$ & $\mathrm{A} / \mathrm{La}$ & Usar peças como se fossem dinheiro & $\mathrm{C} / \mathrm{Li}$ \\
\hline & & Empurrá-lo(s) sobre o chão / a mesa & $\begin{array}{l}\text { B/Gu (2) } \\
\mathrm{Gu} / \mathrm{B} \\
\mathrm{C} / \mathrm{H} \\
\mathrm{C}-\mathrm{H}(2) \\
\mathrm{C} / \mathrm{Li} \\
\mathrm{H} / \mathrm{Gu} \\
\mathrm{Li} / \mathrm{Gi} \\
\mathrm{S} / \mathrm{La}\end{array}$ & & \\
\hline \multirow{2}{*}{$\begin{array}{l}\text { Trem e caminhão de } \\
\text { plástico com peças de } \\
\text { encaixar (tipo quebra- } \\
\text { cabeças - } 24 . d \text { ) }\end{array}$} & & Encaixar / desencaixar rodas & $\begin{array}{l}\mathrm{B} / \mathrm{Gu}(3) \\
\mathrm{Gu} \text { imt B } \\
\mathrm{C}-\mathrm{H}(3)\end{array}$ & & \\
\hline & & Empurrá-lo(s) sobre o chão, vocalizando "vrum" & $\mathrm{C}-\mathrm{H}$ & & \\
\hline
\end{tabular}




\section{APÊNDICE 16 - Categorias de objetos com os quais se observou as crianças brincando durante a sessão Conjunta 1, número total de} maneiras como os objetos foram utilizados, modos de utilização dos mesmos e os sujeitos agentes da ação (ou brincadeira). OBS.: a) Os números e letras referem-se à descrição dos objetos contidos no Apêndice 2; b) As seguintes notações que aparecem com as iniciais dos nomes das crianças significam: “”” = criança agente da ação em relação a outra criança; “-“= crianças brincando juntas com os mesmos objetos (todas agentes); “(- )” = crianças brincando juntas, mas apenas a que está fora do parênteses atua sobre o objeto; "imt” = imita (observa e faz o mesmo que outra criança).

\begin{tabular}{|c|c|c|c|c|c|}
\hline $\begin{array}{l}\text { Categoria de } \\
\text { objetos }\end{array}$ & $\mathbf{N}$ & Função igual à usual & Sujeitos $^{2}$ & Função diferente da usual & \\
\hline $\begin{array}{l}\text { Acessórios (bolsas, } \\
\text { sacolas, chapéus - } \\
\text { 3.i, 10.d, 12.d) }\end{array}$ & 1 & Colocar chapéu na cabeça & S & & \\
\hline \multirow{7}{*}{ Bambolês (1.d) } & \multirow{7}{*}{14} & Colocar bambolê(s) no pescoço & $\mathrm{H}$ & Pisar sobre o bambolê & $\begin{array}{l}\mathrm{C} \\
\mathrm{H}\end{array}$ \\
\hline & & Andar segurando bambolê, arrastando-o no chão & $\mathrm{C}$ & $\begin{array}{l}\text { Segurar o bambolê com seu corpo no centro e girar falando "bóia, } \\
\text { bóia..." }\end{array}$ & A \\
\hline & & Segurar o bambolê com as duas mãos, na frente do próprio corpo & $\mathrm{Gi}$ & $\begin{array}{l}\text { Colocar bambolê "deitado" sobre o chão e sentar-se dentro da } \\
\text { circunferência limitada por ele }\end{array}$ & $\mathrm{H}$ \\
\hline & & Colocar bambolê "deitado" sobre o chão e pular dentro dele & $\mathrm{Gi}$ & Tentar tirar fita adesiva que une as pontas do bambolê & $\mathrm{H}$ \\
\hline & & Pôr bambolê em volta do corpo e segurá-lo & $\begin{array}{l}\mathrm{H} \\
\mathrm{Li}\end{array}$ & Sentar-se de pernas cruzadas e segurar o bambolê sobre as pernas & $\mathrm{H}$ \\
\hline & & Bater o bambolê no chão & $\mathrm{Li}$ & & \\
\hline & & Pôr bambolê em volta do corpo e deixá-lo escorregar até o chão & $\mathrm{S}$ & & \\
\hline \multirow{5}{*}{$\begin{array}{l}\text { Barris de plástico } \\
\text { (1.i) }\end{array}$} & \multirow{5}{*}{6} & Abrí-los e tirar um de dentro do outro & $\begin{array}{l}\mathrm{C} \\
\mathrm{Gi}\end{array}$ & & \\
\hline & & Abrir / fechar barris & Gi & & \\
\hline & & Abrir cada barril e colocá-los sobre o chão, como potes & Gi & & \\
\hline & & $\begin{array}{l}\text { Tentar abrir barris girando, uma metade em sentido contrário ao } \\
\text { da outra (eles só abrem se suas partes forem puxadas em sentidos } \\
\text { contrários) }\end{array}$ & $\mathrm{Gu}$ & & \\
\hline & & Chacoalhar barris & $\mathrm{Gi}$ & & \\
\hline Bichos de pelúcia & 13 & Chamar onça de pelúcia de "pantera" & A & Chamar bicho de pelúcia de "nenê" & $\mathrm{Gi}$ \\
\hline
\end{tabular}




\begin{tabular}{|c|c|c|c|c|c|}
\hline $\begin{array}{l}\text { Categoria de } \\
\text { objetos }^{1}\end{array}$ & $\mathbf{N}$ & Função igual à usual & Sujeitos $^{2}$ & Função diferente da usual & \\
\hline \multirow[t]{4}{*}{ (3.d) } & & Abraçar bicho de pelúcia & $\begin{array}{l}\mathrm{Gi} \\
\mathrm{La}\end{array}$ & Dizer que o bicho de pelúcia está doente & $\begin{array}{l}\mathrm{Gi}(2) \\
\mathrm{La}(4)\end{array}$ \\
\hline & & $\begin{array}{l}\text { Tocar num bicho de pelúcia quando uma criança pede para fazer } \\
\text { cócegas no bicho }\end{array}$ & $\mathrm{H} / \mathrm{La}$ & & \\
\hline & & Jogar bichinho longe & $\mathrm{Li}$ & & \\
\hline & & Carregar bicho de pelúcia no colo & $\mathrm{La}$ & & \\
\hline \multirow{9}{*}{$\begin{array}{l}\text { Bóias de cintura } \\
\text { (4.d) }\end{array}$} & \multirow{9}{*}{17} & Colocar a bóia sobre os ombros (no pescoço) & $\begin{array}{l}\mathrm{A} \\
\mathrm{H}\end{array}$ & Segurar a bóia acima da cabeça & A \\
\hline & & Vocaliza “iáh!" e gira a bóia na cintura & A & $\begin{array}{l}\text { Girar em torno de si com os pés no centro da bóia, falando "roda, } \\
\text { roda, roda..." }\end{array}$ & A \\
\hline & & Deixa a bóia escorregar pelo corpo até chegar ao chão & A & Andar com a bóia nos pés, falando "roda, roda, roda..." & A \\
\hline & & Segurar bóia na cintura & $\mathrm{Gi}$ & Sentar-se no chão e pôr a bóia na cintura & $\mathrm{C}$ \\
\hline & & Sentar-se sobre bóias & $\begin{array}{l}\text { C-H-La } \\
\mathrm{H} \\
\mathrm{Li}\end{array}$ & $\begin{array}{l}\text { Sentar-se sobre a bóia colocada na vertical e entre as pernas, como } \\
\text { se ela fosse um cavalinho }\end{array}$ & $\mathrm{Gi}$ \\
\hline & & Movimentar a bóia no ar & $\mathrm{Gi}$ & & \\
\hline & & Sentar-se sobre bóia, segurando boneca & $\mathrm{H}$ & & \\
\hline & & Segurar duas bóias com um braço (no centro delas) & $\mathrm{La}$ & & \\
\hline & & Colocar duas bóias no chão, uma ao lado da outra & La & & \\
\hline \multirow{4}{*}{ Bolas $(2 . i, 5 . d)$} & \multirow{4}{*}{12} & Jogar bola usando as mãos & $\begin{array}{l}\mathrm{C} \\
\mathrm{C}-\mathrm{Gu} \\
\mathrm{S} \\
\end{array}$ & Bater bola no joelho & $\mathrm{C}$ \\
\hline & & Chutar bola & \begin{tabular}{l|l}
$\mathrm{C}$ \\
$\mathrm{Gu}(2)$
\end{tabular} & & \\
\hline & & Jogar a bola para o alto & $\begin{array}{l}\mathrm{C} \\
\mathrm{Gu} \text { imt } \mathrm{C} \\
\mathrm{C}-\mathrm{Gu} \\
\mathrm{Gu}\end{array}$ & & \\
\hline & & Oferecer bola para outra criança & $\mathrm{Li}$ & & \\
\hline Boneca(o)s (4.i, 5.i) & 2 & Carregar boneco(a) no colo & $\mathrm{Li}(2)$ & & \\
\hline $\begin{array}{l}\text { Caminhões de } \\
\text { madeira }(8 . i)\end{array}$ & 1 & Colocar objetos na carroceria do caminhão & $\mathrm{C}$ & & \\
\hline \multirow{2}{*}{$\begin{array}{l}\text { Carros de plástico } \\
\text { com orifícios e peças }\end{array}$} & \multirow[t]{2}{*}{29} & Empurrar carro, fazendo som de motor & $\mathrm{A}(-\mathrm{C})$ & Colocar duas bolas sobre o carro & \\
\hline & & Encaixar / desencaixar peças pelos orifícios do(s) carro(s) & S (2) & Tentar colocar a bola dentro do carro (ela não cabe) & $\mathrm{Gu}$ \\
\hline
\end{tabular}




\begin{tabular}{|c|c|c|c|c|c|}
\hline $\begin{array}{l}\text { Categoria de } \\
\text { objetos }^{1}\end{array}$ & $\mathbf{N}$ & Função igual à usual & Sujeitos $^{2}$ & Função diferente da usual & \\
\hline \multirow[t]{10}{*}{ para encaixar (9.i) } & & Empurrar carro & \begin{tabular}{|l}
$\mathrm{C}(-\mathrm{A})$ \\
$\mathrm{C}-\mathrm{S}$ \\
$\mathrm{La}$ \\
$\mathrm{S}$ \\
\end{tabular} & Empurrar três carros juntos, lado a lado & $\mathrm{H}$ \\
\hline & & Parar de movimentar carro quando outra criança fala "não" & A-C/S & $\begin{array}{l}\text { Dar carro para outra criança, quando esta diz que o bichinho de } \\
\text { pelúcia está doente (ambulância?) }\end{array}$ & $\mathrm{S} / \mathrm{La}$ \\
\hline & & Empurrar carro (de polícia) e fazer som de sirene & $\mathrm{C}$ & Colocar peça de madeira por um dos orifícios do carro & S (2) \\
\hline & & Convidar outra criança para brincar de polícia & $\mathrm{S} / \mathrm{La}(2)$ & Convidar outra criança para brincar de "ui-ui-ui" (sirene?) & $\mathrm{S} / \mathrm{C}$ \\
\hline & & Oferecer carro para outra criança & $\begin{array}{ll}\text { S/C } \\
\text { S/La }\end{array}$ & Empurrar dois carros, fazendo um semicírculo em torno de si & $S$ \\
\hline & & Dizer que está brincando de polícia & S (2) & & \\
\hline & & Colocar um carro ao lado do outro & $\mathrm{S}(2)$ & & \\
\hline & & \begin{tabular}{|l|} 
Tombar dois carros de lado \\
\end{tabular} & $\mathrm{S}$ & & \\
\hline & & Colocar objetos pela porta de trás do carro & S (3) & & \\
\hline & & \begin{tabular}{|l|} 
Referir-se aos carros como sendo da polícia \\
\end{tabular} & $\mathrm{S}$ & & \\
\hline \multirow{2}{*}{$\begin{array}{l}\text { Casinhas com } \\
\text { orifícios e peças para } \\
\text { encaixar (13.d) }\end{array}$} & \multirow[b]{2}{*}{2} & Girar (rosquear / desrosquear) a chaminé da casinha & $\mathrm{S}$ & & \\
\hline & & Virar a casinha (para tirar peças) & $\mathrm{Gu}$ & & \\
\hline Chocalhos (6.i, 20.i) & 2 & Chacoalhar & $\begin{array}{l}\text { Gu } \\
\mathrm{H} \\
\end{array}$ & & \\
\hline Colares (10.i) & 5 & Colocar colar no próprio pescoço & \begin{tabular}{|l}
$\mathrm{A}$ \\
$\mathrm{Gi}$ \\
$\mathrm{Gu}$ \\
$\mathrm{H}$ \\
\end{tabular} & Segurar o colar e rodá-lo no ar & Gi \\
\hline \multirow{2}{*}{$\begin{array}{l}\text { Garrafas pet } \\
\text { pequenas } \\
\text { preenchidas com } \\
\text { água, detergente, } \\
\text { miçangas e } \\
\text { estrelinhas (13.i, } \\
\text { 17.d) }\end{array}$} & \multirow[b]{2}{*}{12} & Inspecionar garrafinha & \begin{tabular}{|l|}
$\mathrm{A} \mathrm{(2)}$ \\
$\mathrm{Gu}$ \\
$\mathrm{H}$ \\
\end{tabular} & Virar garrafinha sobre pote de iogurte e dar (de beber) ao boneco & $\mathrm{Li}$ \\
\hline & & Chacoalhar garrafinha & \begin{tabular}{|l|} 
Gu imt \\
$\mathrm{H}$ \\
$\mathrm{H}$ \\
$\mathrm{Li}(3)$ \\
\end{tabular} & $\begin{array}{l}\text { Virar garrafinha sobre metades de barris (como se fossem copo) e } \\
\text { bebe deles, fazendo barulhinho com a boca }\end{array}$ & Gi \\
\hline
\end{tabular}




\begin{tabular}{|c|c|c|c|c|c|}
\hline $\begin{array}{l}\text { Categoria de } \\
\text { objetos }^{1}\end{array}$ & $\mathbf{N}$ & Função igual à usual & Sujeitos $^{2}$ & Função diferente da usual & \\
\hline \multirow{4}{*}{ Kits médicos (14.i) } & \multirow{4}{*}{20} & Colocar estetoscópio nos ouvidos & $\begin{array}{l}\mathrm{A} \\
\mathrm{C} \\
\mathrm{Gu} \\
\mathrm{H}(3) \\
\mathrm{Li} \mathrm{(2)} \\
\mathrm{S}\end{array}$ & "Auscultar" bicho de pelúcia & $\begin{array}{l}\mathrm{Gi}(-\mathrm{La}) \\
\mathrm{La}\end{array}$ \\
\hline & & $\begin{array}{l}\text { Colocar a seringa na própria boca (como se estivesse tomando } \\
\text { remédio) }\end{array}$ & $\begin{array}{l}\mathrm{Gi} \\
\mathrm{Gu}\end{array}$ & $\begin{array}{l}\text { Colocar seringa na boca do boneco (deitado), como se estivesse } \\
\text { dando remédio }\end{array}$ & $\mathrm{Li}$ \\
\hline & & Encostar estetoscópio no corpo de outra criança e "auscultá-la" & $\mathrm{Li} / \mathrm{H}$ & “Auscultar" boneca & $\mathrm{Li}$ \\
\hline & & & & Colocar estetoscópio na cabeça (como se coloca uma tiara) & $\begin{array}{l}\text { Gi (2) } \\
\mathrm{La} \\
\mathrm{S} \\
\end{array}$ \\
\hline \multirow{7}{*}{ Lanternas (18.d) } & \multirow{7}{*}{22} & Iluminar parede / mesa / chão & $\begin{array}{l}\mathrm{A} \\
\mathrm{H} \\
\mathrm{La} \\
\end{array}$ & Bater na cabeça de outra criança usando a lanterna & $\mathrm{A} / \mathrm{C}$ \\
\hline & & Oferecer a lanterna para outra criança & $\begin{array}{l}\mathrm{A} / \mathrm{La} \\
\mathrm{Li} / \mathrm{La} \\
\mathrm{La} / \mathrm{S}\end{array}$ & Jogar a lanterna em outra criança & $\mathrm{A} / \mathrm{La}$ \\
\hline & & Acender lanterna & $\begin{array}{l}\mathrm{C}(2) \\
\mathrm{C}-\mathrm{S} \\
\mathrm{Gu} \\
\mathrm{H} \\
\mathrm{S} \\
\end{array}$ & Iluminar a própria boca com a lanterna & $\mathrm{C}$ \\
\hline & & $\begin{array}{l}\text { Segurar a lanterna acesa em direção a uma criança que estava } \\
\text { segurando boneco }\end{array}$ & $\mathrm{H}$ & $\begin{array}{l}\text { Iluminar bicho de pelúcia, como se o estivesse examinando (em } \\
\text { brincadeira de médico) }\end{array}$ & $\mathrm{La}(2)$ \\
\hline & & Iluminar boneco & $\mathrm{Li}$ & Encostar a lanterna acesa na orelha & $\mathrm{H}$ \\
\hline & & Iluminar bola (que outra criança segura) & $\mathrm{La}$ & & \\
\hline & & Iluminar parte interna do chapéu & $\mathrm{S}$ & & \\
\hline \multirow{3}{*}{$\begin{array}{l}\text { Livros de estórias } \\
\text { infantis (11.d) }\end{array}$} & \multirow{3}{*}{4} & Abrir o livro de estórias e falar "era uma vez" & A & & \\
\hline & & $\begin{array}{l}\text { Uma criança pede para a outra, que estava com o livro, contar } \\
\text { estória }\end{array}$ & $\mathrm{La} / \mathrm{A}$ & & \\
\hline & & Folhear livro & $\begin{array}{l}\mathrm{Gi} \\
\mathrm{S}\end{array}$ & & \\
\hline $\begin{array}{l}\text { Módulos } \\
\text { geométricos de } \\
\text { madeira (16.i) }\end{array}$ & 1 & $\begin{array}{l}\text { Encaixar / desencaixar peças nos / dos pinos da base do módulo } \\
\text { geométrico }\end{array}$ & $\mathrm{C}$ & & \\
\hline
\end{tabular}




\begin{tabular}{|c|c|c|c|c|c|}
\hline $\begin{array}{l}\text { Categoria de } \\
\text { objetos }^{1}\end{array}$ & $\mathbf{N}$ & Função igual à usual & Sujeitos $^{2}$ & Função diferente da usual & \\
\hline \multirow{8}{*}{$\begin{array}{l}\text { Molas de plástico } \\
\text { (17.i) }\end{array}$} & \multirow{8}{*}{23} & Andar segurando mola estendida & A & Bater em outra criança usando a mola & $\mathrm{A} / \mathrm{La}$ \\
\hline & & Contrair mola & $\begin{array}{l}\text { A } \\
\text { Gi (3) }\end{array}$ & Colocar molas nos braços como se fossem pulseiras & $\begin{array}{l}\mathrm{Gi} \\
\mathrm{H}\end{array}$ \\
\hline & & $\begin{array}{l}\text { Segurar mola estendida e balançá-la levemente em direção ao } \\
\text { chão }\end{array}$ & $\mathrm{C}$ & Esticar molas sobre a mesa até elas encostarem-se ao chão & $\mathrm{Gi}$ \\
\hline & & Esticar a mola até ela encostar-se ao chão & $\begin{array}{l}\mathrm{C} \\
\mathrm{H}\end{array}$ & Encostar mola na boca & $\mathrm{Gi}$ \\
\hline & & $\begin{array}{l}\text { Abrir a mola segurando uma ponta em cada mão e deixando o } \\
\text { meio cair, formando um U. }\end{array}$ & Gi (3) & $\begin{array}{l}\text { Colocar molas nas patas dos bichos de pelúcia, como se fosse } \\
\text { gesso (falam que ele está doente) }\end{array}$ & $\begin{array}{l}\mathrm{Gi} \\
\mathrm{La}-\mathrm{Gi} \\
\mathrm{Gi} \\
\end{array}$ \\
\hline & & Balançar, de um lado para o outro, a mola esticada até o chão & $\mathrm{Gi}$ & Colocar a mola, esticada, ao redor da cintura & $\mathrm{S}$ \\
\hline & & Esticar mola & $\mathrm{H}$ & & \\
\hline & & $\begin{array}{l}\text { Abrir a mola segurando uma ponta em cada mão, mantendo-a na } \\
\text { horizontal }\end{array}$ & $\mathrm{S}$ & & \\
\hline \multirow{4}{*}{ Óculos (20.d) } & \multirow{4}{*}{17} & Pôr óculos no rosto (na frente dos olhos) & $\begin{array}{l}\mathrm{C} \mathrm{(2)} \\
\mathrm{C}-\mathrm{H}-\mathrm{La} \\
\mathrm{Gu}(2) \\
\mathrm{H}(2) \\
\mathrm{La} \\
\mathrm{Li}(2) \\
\end{array}$ & & \\
\hline & & Comparar seus óculos com os de outras crianças & C-H-Li & & \\
\hline & & Pôr óculos na cabeça (como tiara) & $\begin{array}{l}\mathrm{C} \text { imt } \mathrm{H} \\
\mathrm{Gu} \\
\mathrm{H}\left(1^{\circ}\right) \\
(2)\end{array}$ & & \\
\hline & & Oferecer óculos para outra criança & $\begin{array}{l}\mathrm{Gu} / \mathrm{Li} \\
\mathrm{Gu} / \mathrm{La}\end{array}$ & & \\
\hline $\begin{array}{l}\text { Quebra-cabeças } \\
\text { (22.d) }\end{array}$ & 1 & Montar / desmontar & $\mathrm{La}$ & & \\
\hline
\end{tabular}




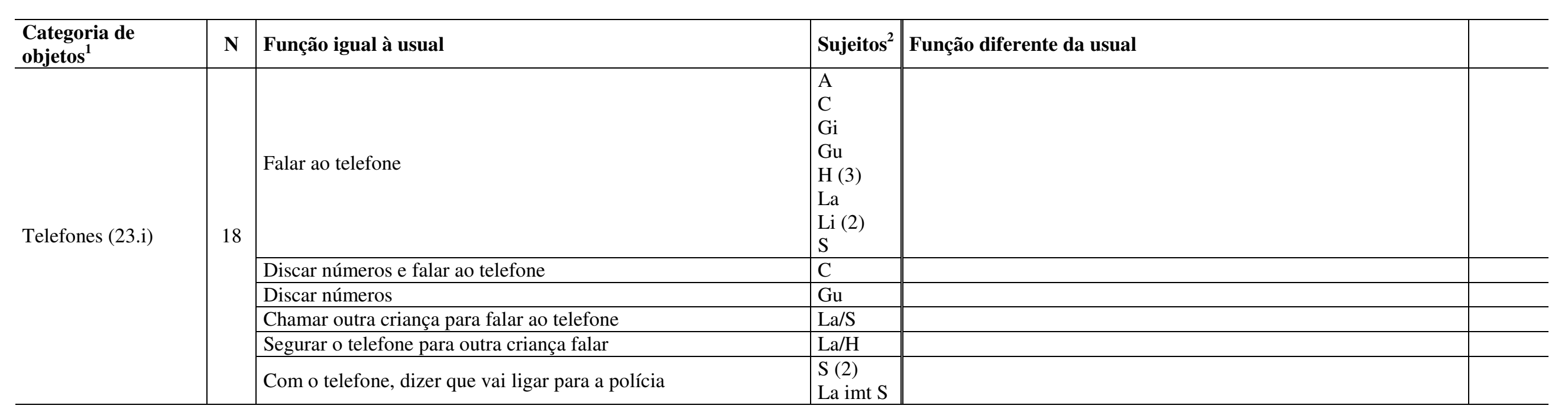




\section{APÊNDICE 17 - Categorias de objetos com os quais se observou as crianças brincando durante a sessão Conjunta 2, número total de} maneiras como os objetos foram utilizados, modos de utilização dos mesmos e os sujeitos agentes da ação (ou brincadeira). OBS.: a) Os números e letras referem-se à descrição dos objetos contidos no Apêndice 2; b) As seguintes notações que aparecem com as iniciais dos nomes das crianças significam: “”” = criança agente da ação em relação a outra criança; “-“= crianças brincando juntas com os mesmos objetos (todas agentes); “(- )" = crianças brincando juntas, mas apenas a que está fora do parênteses atua sobre o objeto; "imt” = imita (observa e faz o mesmo que outra criança).

\begin{tabular}{|c|c|c|c|c|c|}
\hline Categoria de objetos ${ }^{1}$ & $\mathbf{N}$ & Função igual à usual & Sujeitos $^{2}$ & Função diferente da usual & Sujeitos $^{2}$ \\
\hline \multirow{8}{*}{$\begin{array}{l}\text { Acessórios (bolsas, sacolas, } \\
\text { chapéus - 3.i, 10.d, 12.d) }\end{array}$} & \multirow{8}{*}{15} & Colocar chapéu na cabeça & \begin{tabular}{|l|}
$\mathrm{Gu}$ \\
$\mathrm{S}$ \\
\end{tabular} & Colocar chapéu sobre a cabeça de bicho de pelúcia & $S$ \\
\hline & & Dar objeto para outra criança guardar na sacola & $\mathrm{Li} / \mathrm{La}$ & & \\
\hline & & Segurar bolsa & $\begin{array}{ll}\mathrm{H} \\
\mathrm{Li}(3)\end{array}$ & & \\
\hline & & Colocar objetos dentro da bolsa / sacola & $\mathrm{Li}$ & & \\
\hline & & Oferecer bolsa para outra criança & $\begin{array}{l}\mathrm{S} / \mathrm{H} \\
\mathrm{La} / \mathrm{Li} \\
\end{array}$ & & \\
\hline & & Colocar sacola no ombro & $\mathrm{La}$ & & \\
\hline & & Tirar objetos de dentro da bolsa & $\mathrm{Li}$ & & \\
\hline & & $\begin{array}{l}\text { Segurar bolsa aberta para outra criança colocar } \\
\text { objetos dentro dela }\end{array}$ & $\begin{array}{l}\mathrm{La} / \mathrm{S} \\
\mathrm{La} / \mathrm{Li} \\
\end{array}$ & & \\
\hline \multirow{3}{*}{ Bambolês (1.d) } & \multirow{3}{*}{5} & Colocar bambolê(s) no pescoço & $\mathrm{Gu}$ & $\begin{array}{l}\text { Sentar-se com dois bambolês em volta do corpo e colocar as } \\
\text { pernas sobre eles }\end{array}$ & A \\
\hline & & & & $\begin{array}{l}\text { Colocar bambolê "deitado" sobre o chão e sentar-se dentro } \\
\text { da circunferência limitada por ele }\end{array}$ & $\begin{array}{l}\text { A } \\
\text { Gu imt A }\end{array}$ \\
\hline & & & & Tentar tirar fita que une as pontas do bambolê & A \\
\hline $\begin{array}{l}\text { Bandejas de plástico e de } \\
\text { isopor (2.d) }\end{array}$ & 1 & $\begin{array}{l}\text { Oferecer bandeja com objetos dentro para outra } \\
\text { criança }\end{array}$ & $\mathrm{C} / \mathrm{La}$ & & \\
\hline \multirow[t]{2}{*}{ Barris de plástico (1.i) } & \multirow[t]{2}{*}{3} & Abrir / fechar barris & $\begin{array}{l}\mathrm{A} \\
\mathrm{H} \\
\end{array}$ & & \\
\hline & & Bater barris fechados (o conjunto) sobre a mesa & $\mathrm{Gu}$ & & \\
\hline Bichos de pelúcia (3.d) & 8 & Abraçar bicho de pelúcia & $\begin{array}{l}\mathrm{H} \\
\mathrm{S}\end{array}$ & Chamar bicho de pelúcia de "meu filho" & Gi \\
\hline
\end{tabular}




\begin{tabular}{|c|c|c|c|c|c|}
\hline Categoria de objetos $^{1}$ & $\mathbf{N}$ & Função igual à usual & Sujeitos $^{2}$ & Função diferente da usual & Sujeitos $^{2}$ \\
\hline & & Carregar bicho de pelúcia no colo & $\begin{array}{l}\mathrm{Gi} \\
\mathrm{S}\end{array}$ & Dizer que o bicho de pelúcia está doente & Gi \\
\hline & & & & Dançar e cantar carregando bicho de pelúcia & S \\
\hline & & & & Chamar bicho de pelúcia de "meu amigo" & S \\
\hline \multirow{10}{*}{ Bóias de cintura (4.d) } & \multirow{10}{*}{20} & Colocar a bóia sobre os ombros (no pescoço) & $\begin{array}{l}\mathrm{A} \\
\mathrm{H} \\
\mathrm{La}\end{array}$ & Girar em torno de si segurando a bóia na cintura & A \\
\hline & & $\begin{array}{l}\text { Segurando três bóias, oferece bóias para outras } \\
\text { crianças }\end{array}$ & $\mathrm{La}$ & $\begin{array}{l}\text { Girar em torno de si com os pés no centro da bóia, falando } \\
\text { "roda, roda, roda..." }\end{array}$ & A \\
\hline & & Segurar bóia na cintura & $\begin{array}{l}\mathrm{A} \\
\mathrm{Gi}\end{array}$ & Deitar bicho de pelúcia sobre a bóia & $\mathrm{Gi}(2)$ \\
\hline & & Sentar-se sobre bóia & $\begin{array}{l}\mathrm{Gu} \\
\mathrm{H}\end{array}$ & Pisar sobre a bóia & $\mathrm{Gu}-\mathrm{S}$ \\
\hline & & Segurar bóia ao lado do corpo & $\mathrm{Gi}$ & & \\
\hline & & Sentar-se sobre bóia, segurando bicho de pelúcia & $\mathrm{H}$ & & \\
\hline & & Segurar duas bóias com um braço (no centro delas) & $\mathrm{La}$ & & \\
\hline & & Colocar duas bóias no chão, uma ao lado da outra & $\mathrm{La}$ & & \\
\hline & & Oferecer bóias para outras crianças & $\mathrm{La}$ & & \\
\hline & & Segurar bóia no braço & $\mathrm{La}(2)$ & & \\
\hline \multirow{3}{*}{ Bolas $(2 . i, 5 . d)$} & \multirow{3}{*}{3} & Lançar bola em direção à parede & $\mathrm{Gu}$ & & \\
\hline & & Jogar a bola para o alto & $\mathrm{Gu}$ & & \\
\hline & & Oferecer bola para outra criança & $\mathrm{C} / \mathrm{La}$ & & \\
\hline \multirow[b]{2}{*}{ Boneca(o)s (4.i, 5.i) } & \multirow[b]{2}{*}{4} & Carregar boneco(a) no colo & $\mathrm{Li}(2)$ & Tirar os membros e a cabeça da boneca (desmontar) & $\mathrm{C}$ \\
\hline & & $\begin{array}{l}\text { Carregar boneco no colo, como se fosse um bebê: } \\
\text { segura sua cabeça }\end{array}$ & $\mathrm{Li}$ & & \\
\hline \multirow{2}{*}{$\begin{array}{l}\text { Bonecos pequenos articulados } \\
\text { (6.i) }\end{array}$} & \multirow{2}{*}{3} & Oferecer bonequinho para outra criança & $\mathrm{C} / \mathrm{La}$ & Chamar bonequinho de remédio & $\mathrm{C}$ \\
\hline & & & & Colocar bonequinho na boca & $\mathrm{Gu}$ \\
\hline \multirow{3}{*}{ Caixas de papelão (7.i, 7.d) } & \multirow{3}{*}{17} & Entrar nas caixas (cada criança numa caixa) & $\mathrm{Li}$ & \begin{tabular}{|l|} 
Sentar-se dentro da caixa segurando boneco Tikinho e bolsa \\
\end{tabular} & $\mathrm{Li}$ \\
\hline & & Colocar / guardar / jogar objetos dentro da caixa & $\begin{array}{l}\mathrm{C}(2) \\
\mathrm{La}(3) \\
\mathrm{Li}(4) \\
\mathrm{La}-\mathrm{Li}(2) \\
\mathrm{La}-\mathrm{S} \\
\mathrm{S} \\
\end{array}$ & & \\
\hline & & Tirar objetos da caixa & \begin{tabular}{|l|l}
$\mathrm{Li}$ \\
$\mathrm{La}-\mathrm{Li}$ \\
\end{tabular} & & \\
\hline
\end{tabular}




\begin{tabular}{|c|c|c|c|c|c|}
\hline Categoria de objetos $^{1}$ & $\mathbf{N}$ & Função igual à usual & Sujeitos $^{2}$ & Função diferente da usual & Sujeitos $^{2}$ \\
\hline Caminhões de madeira (8.i) & 1 & Colocar objetos na carroceria do caminhão & $\mathrm{Li}$ & & \\
\hline \multirow{7}{*}{$\begin{array}{l}\text { Carros de plástico com } \\
\text { orifícios e peças para encaixar } \\
(9 . i)\end{array}$} & \multirow{7}{*}{11} & Empurrar carro & $\begin{array}{l}\mathrm{Gu} \\
\mathrm{H}\end{array}$ & Empurrar carro da mesa ao chão & $\mathrm{H}$ \\
\hline & & Virar carro para tentar tirar objetos de dentro dele & $\mathrm{Gu}$ & Colocar seringa por um dos orifícios do carro & $\mathrm{Gu}$ \\
\hline & & Colocar um carro ao lado do outro & $\begin{array}{l}\mathrm{S} \\
\mathrm{C}-\mathrm{S}\end{array}$ & & \\
\hline & & Abrir e fechar porta traseira do carro & $\mathrm{S}$ & & \\
\hline & & Oferecer carro para outra criança & $\mathrm{C} / \mathrm{S}$ & & \\
\hline & & $\begin{array}{l}\text { Levar o carro até a mesa, fazendo som "ui-ui-ui” } \\
\text { (sirene?) }\end{array}$ & $\mathrm{S}$ & & \\
\hline & & $\begin{array}{l}\text { Levar, empurrando no chão, um carro de cada vez } \\
\text { (quatro no total) até o outro lado da sala, fazendo } \\
\text { som "ui-ui-ui" (sirene?) }\end{array}$ & $\mathrm{S}$ & & \\
\hline \multirow{3}{*}{$\begin{array}{l}\text { Casinhas com lacunas e peças } \\
\text { para encaixar (13.d) }\end{array}$} & \multirow{3}{*}{4} & Encaixar peças nas lacunas da casinha & $\begin{array}{l}\mathrm{C} \\
\mathrm{C}-\mathrm{La}\end{array}$ & & \\
\hline & & Girar (rosquear / desrosquear) a chaminé da casinha & $\mathrm{C}$ & & \\
\hline & & $\begin{array}{l}\text { Tirar / colocar peças da casinha pelo buraco da } \\
\text { chaminé }\end{array}$ & C-La & & \\
\hline \multirow[t]{2}{*}{ Chocalhos (6.i, 20.i) } & \multirow[t]{2}{*}{4} & Chacoalhar & $\begin{array}{l}\mathrm{A} \\
\mathrm{C} \\
\mathrm{Gu} \\
\end{array}$ & & \\
\hline & & Oferecer para outra criança & $\mathrm{C} / \mathrm{La}$ & & \\
\hline \multirow[t]{2}{*}{ Colares (10.i) } & \multirow[t]{2}{*}{5} & Colocar colar no próprio pescoço & $\begin{array}{l}\mathrm{Li}(2) \\
\mathrm{La}-\mathrm{Li}\end{array}$ & & \\
\hline & & Oferecer para outra criança & $\mathrm{C} / \mathrm{La}(2)$ & & \\
\hline \multirow[t]{2}{*}{ Fantoches (14.d, 15.d) } & \multirow[t]{2}{*}{2} & $\begin{array}{l}\text { Por a mão dentro do pato e apertar seu bico } \\
\text { (ativando a buzina e a língua de sogra) }\end{array}$ & $\mathrm{H}$ & & \\
\hline & & Pôr a mão dentro do fantoche & $\mathrm{S}$ & & \\
\hline \multirow{3}{*}{$\begin{array}{l}\text { Garrafas pet pequenas } \\
\text { preenchidas com água, } \\
\text { detergente, miçangas e } \\
\text { estrelinhas }(13 . i, 17 . d)\end{array}$} & \multirow{3}{*}{6} & Chacoalhar garrafinha & $\begin{array}{l}\mathrm{Gu} \\
\mathrm{La} \\
\mathrm{Li}(2)\end{array}$ & & \\
\hline & & $\begin{array}{l}\text { Chacoalhar garrafinha e colocá-la próximo ao } \\
\text { ouvido (para ouvir o barulhinho) }\end{array}$ & $\mathrm{C}$ & & \\
\hline & & Oferecer garrafinha para outra criança & $\mathrm{Li} / \mathrm{La}$ & & \\
\hline Kits médicos (14.i) & 18 & Colocar estetoscópio nos ouvidos & $\begin{array}{l}\mathrm{C} \\
\mathrm{Gu}(3) \\
\mathrm{La}\end{array}$ & Referir-se à seringa como sendo remédio & $\mathrm{C}$ \\
\hline
\end{tabular}




\begin{tabular}{|c|c|c|c|c|c|}
\hline Categoria de objetos $^{1}$ & $\mathbf{N}$ & Função igual à usual & Sujeitos $^{2}$ & Função diferente da usual & Sujeitos $^{2}$ \\
\hline & & $\begin{array}{l}\text { Colocar a seringa na própria boca (como se estivesse } \\
\text { tomando remédio) }\end{array}$ & \begin{tabular}{l|l}
$\mathrm{C}(2)$ \\
$\mathrm{Gu}$
\end{tabular} & & \\
\hline & & $\begin{array}{l}\text { Movimentar, para dentro e para fora, o êmbolo da } \\
\text { seringa }\end{array}$ & $\mathrm{Li}$ & "Auscultar" bicho de pelúcia & $\begin{array}{l}\mathrm{Gi} \\
\mathrm{Gu}\end{array}$ \\
\hline & & $\begin{array}{l}\text { Encostar estetoscópio no próprio corpo e "auscultar- } \\
\text { se" }\end{array}$ & $\mathrm{C}$ & "Auscultar" boneca & $\mathrm{Gu}$ \\
\hline & & Colocar seringa dentro do pote de iogurte & $\mathrm{Li}$ & Colocar estetoscópio na cabeça (como se coloca uma tiara) & Gi \\
\hline & & $\begin{array}{l}\text { Colocar a seringa na boca de outra criança (como se } \\
\text { estivesse dando remédio para ela) }\end{array}$ & $\mathrm{La} / \mathrm{C}$ & “Auscultar" fantoche (de pato) & $\mathrm{Gu}$ \\
\hline \multirow{7}{*}{ Lanternas (18.d) } & \multirow{7}{*}{24} & Iluminar parede / mesa / chão & $\begin{array}{l}\mathrm{A} \\
\mathrm{Gu}\end{array}$ & Enrolar lanterna na camiseta & $\mathrm{H}$ \\
\hline & & Iluminar bóia & $\begin{array}{l}\mathrm{Gu} \\
\mathrm{S}\end{array}$ & $\begin{array}{l}\text { Passar a lanterna nos lábios de outra criança (como se fosse } \\
\text { baton) }\end{array}$ & $\mathrm{Li} / \mathrm{A}$ \\
\hline & & Acender lanterna & $\begin{array}{l}\mathrm{C} \\
\mathrm{S}\end{array}$ & Passar a lanterna nos próprios lábios (como se fosse baton) & $\mathrm{Li}$ \\
\hline & & Trocar lanterna com outra criança & $\mathrm{C} / \mathrm{S}$ & Iluminar o próprio rosto & $\mathrm{S}(2)$ \\
\hline & & Iluminar parede, balançando a lanterna & A & $\begin{array}{l}\text { Movimentar lanterna de um lado para o outro (como se fosse } \\
\text { uma mangueira d'água) }\end{array}$ & $\begin{array}{l}\mathrm{C} \\
\mathrm{S} \text { imt C }\end{array}$ \\
\hline & & Iluminar outra criança & $\begin{array}{l}\mathrm{A} / \mathrm{S} \\
\mathrm{S} / \mathrm{Gu}\end{array}$ & $\begin{array}{l}\text { Apontar lanterna para outra criança, como se ela fosse uma } \\
\text { arma }\end{array}$ & $\mathrm{S} / \mathrm{H}$ \\
\hline & & Iluminar objetos & $\begin{array}{l}\mathrm{Gu}-\mathrm{S} \\
\mathrm{H} \\
\mathrm{La} \\
\mathrm{Li} \\
\mathrm{S}(2) \\
\end{array}$ & & \\
\hline $\begin{array}{l}\text { Latas de leite com uma bola } \\
\text { dentro (15.i) }\end{array}$ & 1 & Chacoalhar & $\mathrm{C}$ & & \\
\hline \multirow{4}{*}{$\begin{array}{l}\text { Livros de estórias infantis } \\
\text { (11.d) }\end{array}$} & \multirow{4}{*}{5} & Contar estória para outras crianças & Gi/H-La & Segurar livro por uma de suas folhas e balançá-lo & \\
\hline & & Folhear livro & $\begin{array}{l}\mathrm{Gi} \\
\mathrm{La}\end{array}$ & & \\
\hline & & $\begin{array}{l}\text { Folhear livro e falar sozinha, como se estivesse } \\
\text { contando estória }\end{array}$ & $\mathrm{Gi}$ & & \\
\hline & & $\begin{array}{l}\text { Ouvir estória que outra criança, segurando livro } \\
\text { aberto, conta }\end{array}$ & $\mathrm{La} / \mathrm{Gi}$ & & \\
\hline \multirow[t]{2}{*}{ Molas de plástico (17.i) } & \multirow[t]{2}{*}{3} & $\begin{array}{l}\text { Esticar e contrair mola encostada no chão } \\
\text { (horizontal) }\end{array}$ & $\mathrm{C}$ & Colocar molas nos braços como se fossem pulseiras & $\mathrm{H}$ \\
\hline & & Esticar mola sobre a mesa & $\mathrm{Gu}$ & & \\
\hline
\end{tabular}




\begin{tabular}{|c|c|c|c|c|c|}
\hline Categoria de objetos $^{1}$ & $\mathbf{N}$ & Função igual à usual & Sujeitos $^{2}$ & Função diferente da usual & Sujeitos $^{2}$ \\
\hline \multirow[t]{2}{*}{ Óculos (20.d) } & \multirow[t]{2}{*}{7} & Pôr óculos no rosto (na frente dos olhos) & $\begin{array}{l}\mathrm{C} \\
\mathrm{Gu} \\
\mathrm{La}(2) \\
\mathrm{Li}(2)\end{array}$ & & \\
\hline & & Oferecer óculos para outra criança & $\mathrm{Li} / \mathrm{A}$ & & \\
\hline $\begin{array}{l}\text { Peças de plástico, de madeira } \\
(18 . i, 21 . d, 26 . d)\end{array}$ & 2 & Encaixar / desencaixar peças (Big Block) & $\mathrm{C}(2)$ & & \\
\hline Potes de iogurte (19.i) & 1 & Colocar um dentro do outro & $\mathrm{Li}$ & & \\
\hline Quebra-cabeças (22.d) & 2 & Montar / desmontar & $\begin{array}{l}\mathrm{A} \\
\mathrm{C}\end{array}$ & & \\
\hline Telefones (23.i) & 2 & Falar ao telefone & $\begin{array}{l}\mathrm{C} \\
\mathrm{H}\end{array}$ & & \\
\hline \multirow{3}{*}{ Tubos de papelão (24.i e 25.d) } & \multirow{3}{*}{7} & Apontar tubo em direção a outra criança & $\mathrm{S} / \mathrm{Gu}$ & Pôr tubo na boca & $\mathrm{Gu}$ \\
\hline & & Jogar tubo no chão & $\mathrm{S}$ & Bater com tubo em outra criança & $\begin{array}{l}\mathrm{S} / \mathrm{Gu} \\
\mathrm{S} / \mathrm{H}(2)\end{array}$ \\
\hline & & & & Bater com tubo na bóia & $\mathrm{S}$ \\
\hline
\end{tabular}




\section{APÊNDICE 18 - Categorias de objetos, e ações sobre eles ou brincadeiras que foram} comuns entre os focais do último semestre, a última sessão de cada dupla e as duas sessões conjuntas (comparação das tabelas contidas

nos Apêndices 14, 15, 16 e 17).

\begin{tabular}{|c|c|c|c|c|c|}
\hline Categoria de objetos & $\begin{array}{c}\text { Ação sobre o objeto / } \\
\text { brincadeira }\end{array}$ & Focais & Duplas & Conjunta 1 & Conjunta 2 \\
\hline \multirow{5}{*}{$\begin{array}{l}\text { Acessórios (bolsas, } \\
\text { sacolas, chapéus) }\end{array}$} & Abrir e fechar (bolsa) & A & $\mathrm{H} / \mathrm{C}(2)$ & -- & -- \\
\hline & $\begin{array}{l}\begin{array}{l}\text { Colocar objetos dentro } \\
\text { (bolsa, sacola) }\end{array} \\
\end{array}$ & $\mathrm{Gi}, \mathrm{C}$ & $\mathrm{C}-\mathrm{Li}$ & -- & $\mathrm{Li}$ \\
\hline & $\begin{array}{l}\text { "Vestir" (bolsas - no } \\
\text { ombro, no pescoço, no } \\
\text { braço, na mão; chapéus - } \\
\text { na cabeça) }\end{array}$ & $\mathrm{Gi}, \mathrm{La}(2), \mathrm{S}$ & $\begin{array}{l}\text { Gi-Li, H/A } \\
(2)\end{array}$ & $S$ & $\mathrm{Gu}, \mathrm{S}$ \\
\hline & $\begin{array}{l}\text { Colocar objetos dentro da } \\
\text { bolsa e ir passear / fazer } \\
\text { compras }\end{array}$ & $S(2)$ & $\mathrm{C}-\mathrm{Li}, \mathrm{Li} / \mathrm{C}$ & -- & -- \\
\hline & $\begin{array}{l}\text { Colocar sacola / bolsinha } \\
\text { sobre a própria cabeça }\end{array}$ & $\mathrm{C}$ & $\mathrm{Li} / \mathrm{C}$ & -- & -- \\
\hline \multirow{10}{*}{ Boneca(o)s } & Dar comida / bebida & A (3), C & $\mathrm{Gi} / \mathrm{H}$ & $\mathrm{Li}$ & -- \\
\hline & Beijar & $\mathrm{Gu}$ & B-Li & -- & -- \\
\hline & Cuidar / tratar & $\mathrm{A}(2), \mathrm{La}$ & $\mathrm{B} / \mathrm{A}$ & -- & -- \\
\hline & Carregar no colo & $\mathrm{S}$ & $\begin{array}{l}\mathrm{A} / \mathrm{Gi}(2) \\
\mathrm{A} / \mathrm{Gu}\end{array}$ & $\operatorname{Li}(2)$ & $\mathrm{Li}(2)$ \\
\hline & $\begin{array}{l}\text { Ninar (fazer dormir dando } \\
\text { batidinhas no corpo) }\end{array}$ & B (2) & $\begin{array}{l}\text { B-Li (2), } \\
\text { Gu/Gi }\end{array}$ & -- & -- \\
\hline & Abraçar & $\mathrm{Li}$ & $\mathrm{A} / \mathrm{La}, \mathrm{Li} / \mathrm{C}$ & -- & -- \\
\hline & $\begin{array}{l}\text { Deitar sobre pano } \\
\text { estendido }\end{array}$ & $\mathrm{Li}$ & $\begin{array}{l}\mathrm{Li} / \mathrm{A} \mathrm{(3)}, \\
\mathrm{B} / \mathrm{Li}(2), \\
\mathrm{Gu} / \mathrm{H}, \\
\mathrm{H} \text { imt Gu } \\
\end{array}$ & -- & -- \\
\hline & Cobrir com pano & $\mathrm{B}$ & $\mathrm{Li} / \mathrm{A}(3)$ & -- & -- \\
\hline & Dançar (com) & Gi & $\mathrm{Li} / \mathrm{A}$ & -- & -- \\
\hline & Falar (com) & Gi (2) & $\mathrm{La} / \mathrm{Gi}$ & -- & -- \\
\hline $\begin{array}{l}\text { Brinquedos com } \\
\text { orifícios e peças para } \\
\text { encaixar (carros e } \\
\text { casinhas nas duplas e } \\
\text { conjuntas) }\end{array}$ & $\begin{array}{l}\text { Encaixar peças nos } \\
\text { orifícios }\end{array}$ & $\mathrm{A}, \mathrm{Gu}$ & $\begin{array}{l}\text { A-C, A/H, } \\
\mathrm{La} / \mathrm{Gi}, \mathrm{Gu} / \mathrm{B}, \\
\mathrm{Li} / \mathrm{B}, \mathrm{C} / \mathrm{Li} \\
(2), \mathrm{H} / \mathrm{Gu} \\
\mathrm{La} / \mathrm{S}, \mathrm{S} / \mathrm{La}\end{array}$ & $S(2)$ & $\mathrm{C}, \mathrm{C}-\mathrm{La}$ \\
\hline \multirow{4}{*}{$\begin{array}{l}\text { Carros (caminhões de } \\
\text { madeira e carros de } \\
\text { plástico nas duplas e } \\
\text { conjuntas) }\end{array}$} & Empurrar / friccionar & $\begin{array}{l}\text { B (2), La, } \\
\mathrm{Gi}, \mathrm{C}(2), \mathrm{H} \\
(2)\end{array}$ & $\begin{array}{l}\mathrm{Gi} / \mathrm{A}, \mathrm{C} / \mathrm{Gi}, \\
\mathrm{H} / \mathrm{S}, \mathrm{A} / \mathrm{C}(2), \\
\mathrm{C} \mathrm{imt} \mathrm{A}, \\
\mathrm{H} / \mathrm{A}(2), \\
\mathrm{La} / \mathrm{Gi}\end{array}$ & $\begin{array}{l}\text { C(-A), C-S, } \\
\mathrm{La}, \mathrm{S}\end{array}$ & $\mathrm{Gu}, \mathrm{H}$ \\
\hline & $\begin{array}{l}\text { Colocar objetos dentro do } \\
\text { carro e empurrá-lo }\end{array}$ & $\mathrm{Gi}, \mathrm{H}$ & $\mathrm{Gi} / \mathrm{La}$ & -- & -- \\
\hline & $\begin{array}{l}\text { Deslizar o carro no ar, } \\
\text { como se ele estivesse } \\
\text { voando }\end{array}$ & $\mathrm{Gi}$ & $\mathrm{H} / \mathrm{Gi}$ & -- & -- \\
\hline & $\begin{array}{l}\text { Referir-se ao carro como } \\
\text { sendo da polícia }\end{array}$ & $S$ & -- & S (3) & -- \\
\hline $\begin{array}{l}\text { Embalagens de } \\
\text { cosméticos (focais) e } \\
\text { garrafinhas (duplas e } \\
\text { conjuntas) }\end{array}$ & $\begin{array}{l}\text { Fazer movimento como se } \\
\text { vertesse o "conteúdo" de } \\
\text { uma embalagem para outra }\end{array}$ & A & $\mathrm{Gi} / \mathrm{A}$ & -- & -- \\
\hline Mesas, cadeiras & $\begin{array}{l}\text { Tentar subir / subir sobre a } \\
\text { mesa }\end{array}$ & A & $\mathrm{S} / \mathrm{C}, \mathrm{C}$ imt $\mathrm{S}$ & -- & -- \\
\hline
\end{tabular}




\begin{tabular}{l|l|l|c|c|c}
\hline Categoria de objetos & \multicolumn{1}{|c|}{$\begin{array}{c}\text { Ação sobre o objeto / } \\
\text { brincadeira }\end{array}$} & \multicolumn{1}{|c|}{ Focais } & Duplas & Conjunta 1 & Conjunta 2 \\
\hline $\begin{array}{l}\text { Panos, lenços, tecidos } \\
\text { (feltros e lenços nas } \\
\text { duplas e conjuntas) }\end{array}$ & Dobrar / desdobrar & $\mathrm{A}, \mathrm{Li}$ & $\mathrm{A} / \mathrm{Gu}$ & -- & -- \\
\hline $\begin{array}{l}\text { Peças de plástico, de } \\
\text { madeira }\end{array}$ & $\begin{array}{l}\text { Passar ou esfregar peças } \\
\text { no corpo de outra criança } \\
\text { brincadeira de médico) }\end{array}$ & $\mathrm{H}, \mathrm{S}$ & $\mathrm{Gi} / \mathrm{La}(4)$ & -- & -- \\
\hline Quebra-cabeças & Montar / desmontar & $\mathrm{A}, \mathrm{C}, \mathrm{H}$ & -- & $\mathrm{La}$ & $\mathrm{A}, \mathrm{C}$ \\
\hline \multirow{2}{*}{$\begin{array}{l}\text { Revistas, livros, } \\
\text { folhetos de } \\
\text { supermercado }\end{array}$} & Ver, folhear & $\begin{array}{l}\mathrm{A}(3), \mathrm{Ga}(2), \\
\mathrm{Gu}(2), \mathrm{H}, \mathrm{S} \\
(2)\end{array}$ & -- & $\mathrm{Gi}, \mathrm{S}$ & $\mathrm{Gi}, \mathrm{La}$ \\
\cline { 2 - 7 } & $\begin{array}{l}\text { Contar estória } \\
\text { Ouvir estória contada por }\end{array}$ & $\mathrm{Ca}, \mathrm{S}$ & -- & -- & $\mathrm{Gi} / \mathrm{H}-\mathrm{La}$ \\
\hline $\begin{array}{l}\text { Telefones } \\
\text { outrança }\end{array}$ & Falar ao telefone & $\begin{array}{l}\mathrm{La}(2), \mathrm{Gu} \\
(2)\end{array}$ & -- & $\begin{array}{l}\mathrm{H}, \mathrm{C}, \mathrm{Gi}, \mathrm{Gu}, \mathrm{La}, \mathrm{Li} \\
(2), \mathrm{S}\end{array}$ & $\mathrm{C}, \mathrm{H}$ \\
\hline $\begin{array}{l}\text { Utensílios de cozinha } \\
\text { (potes de iogurte nas } \\
\text { sessões conjuntas) }\end{array}$ & $\begin{array}{l}\text { Colocar um copo / pote } \\
\text { dentro do outro }\end{array}$ & $\mathrm{Gu}$ & -- & -- & $\mathrm{Li}$ \\
\hline
\end{tabular}




\section{APÊNDICE 19 - Categorias de objetos disponíveis para as crianças brincarem e ações sobre eles ou brincadeiras que foram comuns entre a última sessão de cada dupla e as duas sessões conjuntas (comparação das tabelas contidas nos Apêndices 15, 16 e 17).}

\begin{tabular}{|c|c|c|c|c|}
\hline Categoria de objetos & $\begin{array}{c}\text { Ação sobre o objeto / } \\
\text { brincadeira }\end{array}$ & Duplas & Conjunta 1 & Conjunta 2 \\
\hline \multirow{4}{*}{ Bambolês } & Colocar bambolê no pescoço & $\mathrm{La} / \mathrm{B}, \mathrm{H}-\mathrm{S}$ & $\mathrm{H}$ & $\mathrm{Gu}$ \\
\hline & Bater bambolê no chão & $\begin{array}{l}\mathrm{La} / \mathrm{B}, \mathrm{H} / \mathrm{Gi} \\
\mathrm{Gi} \text { imt H }\end{array}$ & $\mathrm{Li}$ & -- \\
\hline & $\begin{array}{l}\text { Ficar (em pé, sentado, agachado) } \\
\text { dentro da circunferência limitada } \\
\text { por um bambolê "deitado" sobre } \\
\text { o chão }\end{array}$ & $\mathrm{Gi} / \mathrm{C}$ & $\mathrm{H}$ & $\mathrm{A}, \mathrm{Gu}$ imt $\mathrm{A}$ \\
\hline & $\begin{array}{l}\text { Tentar tirar fita adesiva que une } \\
\text { as pontas do bambolê }\end{array}$ & -- & $\mathrm{H}$ & A \\
\hline \multirow{5}{*}{ Barris de plástico } & $\begin{array}{l}\text { Abrí-los e tirar um de dentro do } \\
\text { outro }\end{array}$ & $\begin{array}{l}\mathrm{B} / \mathrm{La}, \mathrm{La} / \mathrm{B}(2), \\
\mathrm{Gi} / \mathrm{C}\end{array}$ & $\mathrm{C}, \mathrm{Gi}$ & -- \\
\hline & Abrir / fechar barris & $\begin{array}{l}\text { A/Gi, La/B, B } \\
\text { imt La, B-La, } \\
\text { C/Gi (6), Gi/C } \\
(3), \mathrm{H} / \mathrm{S}\end{array}$ & $\mathrm{Gi}$ & A, $\mathrm{H}$ \\
\hline & $\begin{array}{l}\text { Abrir cada barril e colocá-los } \\
\text { sobre o chão, como potes }\end{array}$ & $\mathrm{La} / \mathrm{B}$ & Gi & -- \\
\hline & $\begin{array}{l}\text { Tentar abrir barris girando, uma } \\
\text { metade em sentido contrário ao } \\
\text { da outra (eles só abrem se suas } \\
\text { partes forem puxadas em sentidos } \\
\text { contrários) }\end{array}$ & $\begin{array}{l}\text { A/Gi, S/Gu, } \\
\text { Gu imt S }\end{array}$ & $\mathrm{Gu}$ & -- \\
\hline & Chacoalhar barris & $\mathrm{Gu} / \mathrm{S}$ & $\mathrm{Gi}$ & -- \\
\hline \multirow{3}{*}{ Bichos de pelúcia* } & Abraçar bicho de pelúcia & -- & $\mathrm{Gi}, \mathrm{La}$ & $\mathrm{H}, \mathrm{S}$ \\
\hline & Carregar bicho de pelúcia no colo & -- & $\mathrm{La}$ & $\mathrm{Gi}, \mathrm{S}$ \\
\hline & $\begin{array}{l}\text { Dizer que o bicho de pelúcia está } \\
\text { doente }\end{array}$ & -- & Gi (2), La (4) & $\mathrm{Gi}$ \\
\hline \multirow[t]{7}{*}{ Bóias de cintura } & Girar a bóia em torno da cintura & $\begin{array}{l}\mathrm{A} / \mathrm{B}, \mathrm{B} \text { imt } \mathrm{A}, \\
\mathrm{La} / \mathrm{A}, \mathrm{A} / \mathrm{La} \\
\mathrm{Li} / \mathrm{B}(2), \mathrm{Gi} / \mathrm{Gu}\end{array}$ & A & -- \\
\hline & Segurar a bóia na cintura & $\begin{array}{l}\mathrm{A} / \mathrm{B}, \mathrm{A} / \mathrm{La}(2), \\
\mathrm{Gi} / \mathrm{Li}\end{array}$ & Gi & $\mathrm{A}, \mathrm{Gi}$ \\
\hline & $\begin{array}{l}\text { Colocar a bóia sobre os ombros } \\
\text { (no pescoço) }\end{array}$ & $\begin{array}{l}\mathrm{B} / \mathrm{A}, \mathrm{Gu} / \mathrm{B}, \mathrm{B}- \\
\mathrm{Gu}, \mathrm{H} / \mathrm{C}, \mathrm{C} / \mathrm{H}, \\
\mathrm{Gi} / \mathrm{Gu}, \mathrm{H} / \mathrm{Gu} \\
(2), \\
\mathrm{Gu} \text { imt } \mathrm{H}\end{array}$ & $\mathrm{A}, \mathrm{H}$ & $\mathrm{A}, \mathrm{H}, \mathrm{La}$ \\
\hline & $\begin{array}{l}\text { Sentar-se sobre a bóia (cada } \\
\text { criança com uma bóia) }\end{array}$ & $\begin{array}{l}\text { B/A, Gu/Gi, Gi } \\
\text { imt Gu, S/La } \\
(2), \\
\text { La imt S }\end{array}$ & C-H-La, H, Li & $\mathrm{Gu}, \mathrm{H}$ \\
\hline & $\begin{array}{l}\text { Segurar a bóia ao lado do próprio } \\
\text { corpo }\end{array}$ & $\mathrm{A} / \mathrm{La}$ & -- & $\mathrm{Gi}$ \\
\hline & Movimentar a bóia no ar & $\begin{array}{l}\mathrm{H} / \mathrm{Gu}, \\
\mathrm{Gu} \text { imt } \mathrm{H}\end{array}$ & $\mathrm{Gi}$ & -- \\
\hline & $\begin{array}{l}\text { Girar em torno de si com os pés } \\
\text { no centro da bóia, falando "roda, } \\
\text { roda, roda..." }\end{array}$ & $\begin{array}{l}\mathrm{A} / \mathrm{B} \\
\mathrm{B} \text { imt A }\end{array}$ & A & A \\
\hline
\end{tabular}




\begin{tabular}{|c|c|c|c|c|}
\hline Categoria de objetos & \begin{tabular}{|c|}
$\begin{array}{c}\text { Ação sobre o objeto / } \\
\text { brincadeira }\end{array}$ \\
\end{tabular} & Duplas & Conjunta 1 & Conjunta 2 \\
\hline & $\begin{array}{l}\text { Girar em torno de si segurando a } \\
\text { bóia na cintura }\end{array}$ & A/La, La imt A & -- & A \\
\hline & Andar com a bóia nos pés & $\mathrm{B} / \mathrm{Gu}, \mathrm{Gi} / \mathrm{Li}$ & A & -- \\
\hline & $\begin{array}{l}\text { Sentar-se sobre a bóia colocada } \\
\text { na vertical e entre as pernas } \\
\text { como, se ela fosse um } \\
\text { "cavalinho" }\end{array}$ & $\mathrm{Gu} / \mathrm{Gi}$ & $\mathrm{Gi}$ & -- \\
\hline \multirow{4}{*}{ Bolas } & Jogar bola usando as mãos & $\mathrm{C} / \mathrm{Gi}, \mathrm{H} / \mathrm{S}$ & $\mathrm{C}, \mathrm{C}-\mathrm{Gu}, \mathrm{S}$ & -- \\
\hline & Chutar bola & $\mathrm{Gu} / \mathrm{S}, \mathrm{S} / \mathrm{H}, \mathrm{H} / \mathrm{S}$ & $\mathrm{C}, \mathrm{Gu}(2)$ & -- \\
\hline & Jogar a bola para o alto & -- & $\begin{array}{l}\text { C, Gu imt C, } \\
\text { C-Gu, Gu }\end{array}$ & Gu \\
\hline & Oferecer bola para outra criança & -- & $\mathrm{Li}$ & $\mathrm{C} / \mathrm{La}$ \\
\hline $\begin{array}{l}\text { Bonecos pequenos } \\
\text { articulados }\end{array}$ & $\begin{array}{l}\text { Oferecer bonequinho para outra } \\
\text { criança }\end{array}$ & $\mathrm{La} / \mathrm{S}$ & -- & $\mathrm{C} / \mathrm{La}$ \\
\hline \multirow{4}{*}{ Caixas de papelão } & $\begin{array}{l}\text { Entrar na caixa (cada criança } \\
\text { numa caixa) }\end{array}$ & $\begin{array}{l}\text { A-B, A-Li, A- } \\
\text { La }\end{array}$ & -- & $\mathrm{Li}$ \\
\hline & $\begin{array}{l}\text { Colocar / guardar / jogar objetos } \\
\text { dentro da caixa }\end{array}$ & $\begin{array}{l}\mathrm{C} / \mathrm{H}(2), \mathrm{C} / \mathrm{Li} \\
(2), \mathrm{Li} / \mathrm{C}, \mathrm{C} / \mathrm{S}, \\
\mathrm{Gi} / \mathrm{Gu}, \mathrm{A} / \mathrm{Gi}, \\
\mathrm{Gi} / \mathrm{A}(2), \mathrm{Gi} / \mathrm{H} \\
(2), \\
\mathrm{H} \text { imt Gi (2) } \\
\end{array}$ & -- & $\begin{array}{l}\text { C (2), La (3), Li } \\
\text { (4), La-Li (2), } \\
\text { La-S, S }\end{array}$ \\
\hline & Tirar objetos da caixa & $\mathrm{C} / \mathrm{S}$ & -- & $\mathrm{Li}, \mathrm{La}-\mathrm{Li}$ \\
\hline & $\begin{array}{l}\text { Sentar-se dentro da caixa } \\
\text { segurando boneco Tikinho }\end{array}$ & $\mathrm{Li} / \mathrm{Gi}$ & -- & $\mathrm{Li}$ \\
\hline Caminhões de madeira & $\begin{array}{l}\text { Colocar objetos na carroceria do } \\
\text { caminhão }\end{array}$ & $\begin{array}{l}\text { Gi/A (2), B/La, } \\
\text { S/Gu (3), S/H } \\
\text { (3) }\end{array}$ & $\mathrm{C}$ & $\mathrm{Li}$ \\
\hline $\begin{array}{l}\text { Carros de plástico com } \\
\text { orifícios e peças para } \\
\text { encaixar }\end{array}$ & $\begin{array}{l}\text { Colocar objetos dentro do carro } \\
\text { pela porta de trás dele }\end{array}$ & $\begin{array}{l}\mathrm{H} / \mathrm{A}, \mathrm{A} \text { imt } \mathrm{H}, \\
\mathrm{Gi} / \mathrm{La}\end{array}$ & $\mathrm{S}(3)$ & -- \\
\hline \multirow[t]{3}{*}{$\begin{array}{l}\text { Casinhas com orifícios e } \\
\text { peças para encaixar }\end{array}$} & $\begin{array}{l}\text { Girar (rosquear / desrosquear) a } \\
\text { chaminé da casinha }\end{array}$ & $\begin{array}{l}\mathrm{H} / \mathrm{C}, \mathrm{C} \text { imt H, } \\
\mathrm{C} / \mathrm{Li}, \mathrm{S} / \mathrm{C}(2), \\
\mathrm{C} / \mathrm{S}(2), \mathrm{Gu} / \mathrm{Gi}, \\
\mathrm{H} / \mathrm{Gu}(2), \mathrm{Gu} \\
\mathrm{imt} \mathrm{H}\end{array}$ & $S$ & $\mathrm{C}$ \\
\hline & $\begin{array}{l}\text { Tirar / colocar peças da casinha } \\
\text { pelo buraco da chaminé }\end{array}$ & $\mathrm{S} / \mathrm{C}, \mathrm{C} / \mathrm{S}(2)$ & -- & $\mathrm{C} / \mathrm{La}$ \\
\hline & Virar a casinha (para tirar peças) & $\mathrm{H} / \mathrm{Gu}$ & $\mathrm{Gu}$ & -- \\
\hline Chocalhos* & Chacoalhar & -- & $\mathrm{Gu}, \mathrm{H}$ & $\mathrm{A}, \mathrm{C}, \mathrm{Gu}$ \\
\hline Colares & Colocar colar no próprio pescoço & $\begin{array}{l}\mathrm{A} / \mathrm{C}(2), \mathrm{A} / \mathrm{Gu} \\
\mathrm{H} / \mathrm{A}, \mathrm{A} / \mathrm{H} \\
\end{array}$ & $\mathrm{A}, \mathrm{Gi}, \mathrm{Gu}, \mathrm{H}$ & $\mathrm{Li}(2), \mathrm{La}-\mathrm{Li}$ \\
\hline \multirow[t]{2}{*}{ Fantoches } & $\begin{array}{l}\text { Por a mão dentro do pato e } \\
\text { apertar seu bico (ativando a } \\
\text { buzina e a língua de sogra) }\end{array}$ & $\begin{array}{l}\text { A/Gi, A-Gi, } \\
\text { Gi/A }\end{array}$ & -- & $\mathrm{H}$ \\
\hline & Pôr a mão dentro do fantoche & C/A & -- & $\mathrm{S}$ \\
\hline \multirow{4}{*}{$\begin{array}{l}\text { Garrafas pet pequenas } \\
\text { preenchidas com água, } \\
\text { detergente, miçangas e } \\
\text { estrelinhas }\end{array}$} & Chacoalhar garrafinha & $\begin{array}{l}\text { B/La, C/Gi (2), } \\
\text { S/Gu, Gu/S, H- } \\
\mathrm{S}\end{array}$ & $\begin{array}{l}\text { Gu imt H, H, } \\
\operatorname{Li}(3)\end{array}$ & Gu, La, Li (2) \\
\hline & Inspecionar garrafinha & $\mathrm{B} / \mathrm{La}, \mathrm{Gi} / \mathrm{C}(2)$ & $\mathrm{A}(2), \mathrm{Gu}, \mathrm{H}$ & \\
\hline & $\begin{array}{l}\text { Oferecer garrafinha para outra } \\
\text { criança }\end{array}$ & $\mathrm{S} / \mathrm{Gu}$ & -- & $\mathrm{Li} / \mathrm{La}$ \\
\hline & $\begin{array}{l}\text { Virar garrafinha sobre metade de } \\
\text { um barril (como se fosse copo) }\end{array}$ & $\mathrm{C} / \mathrm{Gi}, \mathrm{Gi}$ imt C & $\mathrm{Gi}$ & -- \\
\hline Kits médicos* & Colocar estetoscópio nos ouvidos & -- & $\begin{array}{l}\text { A, C, Gu, H (3), } \\
\mathrm{Li}(2), \mathrm{S}\end{array}$ & $\mathrm{C}, \mathrm{Gu}(3), \mathrm{La}$ \\
\hline
\end{tabular}




\begin{tabular}{|c|c|c|c|c|}
\hline Categoria de objetos & $\begin{array}{c}\text { Ação sobre o objeto / } \\
\text { brincadeira }\end{array}$ & Duplas & Conjunta 1 & Conjunta 2 \\
\hline & $\begin{array}{l}\text { Colocar a seringa na própria boca } \\
\text { (como se estivesse tomando } \\
\text { remédio) }\end{array}$ & -- & $\mathrm{Gi}, \mathrm{Gu}$ & $\mathrm{C}(2), \mathrm{Gu}$ \\
\hline & "Auscultar" bicho de pelúcia & -- & Gi(-La), La & $\mathrm{Gi}, \mathrm{Gu}$ \\
\hline & "Auscultar" boneca & -- & $\mathrm{Li}$ & $\mathrm{Gu}$ \\
\hline & $\begin{array}{l}\text { Colocar estetoscópio na cabeça } \\
\text { (como se coloca uma tiara) }\end{array}$ & -- & Gi (2), La, S & Gi \\
\hline \multirow[b]{2}{*}{ Lanternas } & Iluminar parede / mesa / chão & -- & $\mathrm{A}, \mathrm{H}, \mathrm{La}$ & $\mathrm{A}, \mathrm{Gu}$ \\
\hline & Acender lanterna & -- & $\begin{array}{l}\text { C (2), C-S, Gu, H, } \\
\text { S }\end{array}$ & $\mathrm{C}, \mathrm{S}$ \\
\hline $\begin{array}{l}\text { Módulos geométricos de } \\
\text { madeira }\end{array}$ & $\begin{array}{l}\text { Encaixar / desencaixar peças nos / } \\
\text { dos pinos da base do módulo } \\
\text { geométrico }\end{array}$ & \begin{tabular}{|l} 
B-La, C/Gi (3), \\
Gi/C (2), S/Gu, \\
H/S, S/H \\
\end{tabular} & C & -- \\
\hline Molas de plástico & $\begin{array}{l}\text { Colocar molas nos braços como } \\
\text { se fossem pulseiras }\end{array}$ & -- & $\mathrm{Gi}, \mathrm{H}$ & $\mathrm{H}$ \\
\hline Óculos & $\begin{array}{l}\text { Pôr óculos no rosto (na frente dos } \\
\text { olhos) }\end{array}$ & -- & $\begin{array}{l}\text { C (2), C-H-La, } \\
\text { Gu (2), H (2), La, } \\
\operatorname{Li}(2)\end{array}$ & $\begin{array}{l}\mathrm{C}, \mathrm{Gu}, \mathrm{La}(2), \\
\mathrm{Li}(2)\end{array}$ \\
\hline Óculos & $\begin{array}{l}\text { Oferecer óculos para outra } \\
\text { criança }\end{array}$ & -- & $\mathrm{Gu} / \mathrm{Li}, \mathrm{Gu} / \mathrm{La}$ & $\mathrm{Li} / \mathrm{A}$ \\
\hline
\end{tabular}

* Objetos disponíveis apenas nas sessões conjuntas. 
APÊNDICE 20 - Dados sobre imitação obtidos nos focais iniciais (quatro primeiros) das crianças A, C, Gi, H, La e S (total: 24 focais; 120 minutos; período de 21/8-22/9/03). Ver "notas"na próxima página.

a) Frequiências absolutas.

\begin{tabular}{|c|c|c|c|c|c|c|c|c|}
\hline \multirow{2}{*}{ Ocorrência de interação social após imitação } & & \multicolumn{2}{|c|}{ Ação usual com objeto } & \multicolumn{2}{|c|}{ Ação não usual com objeto } & \multicolumn{2}{|c|}{ Ação sem objeto* } & \multirow{2}{*}{\begin{tabular}{|c|} 
TOTAL \\
16 \\
\end{tabular}} \\
\hline & & Sim & Não & Sim & Não & Sim & Não & \\
\hline \multirow[t]{2}{*}{ Tipo de brincadeira antes da imitação } & Conjunta & 0 & 1 & 3 & 0 & 9 & 8 & 21 \\
\hline & Solitária & 0 & 2 & 2 & 0 & 2 & 4 & 10 \\
\hline \multirow[t]{2}{*}{ Repetição da ação imitada** } & Sim & 0 & 1 & 2 & 0 & 3 & 1 & 7 \\
\hline & Não & 0 & 2 & 3 & 0 & 8 & 11 & 24 \\
\hline \multirow[t]{2}{*}{ Repetição da ação imitada em outro episódio } & Sim & 0 & 0 & 0 & 0 & 0 & 1 & 1 \\
\hline & Não & & & & & & & \\
\hline \multirow[t]{2}{*}{ Repetição da ação imitada num outro dia } & Sim & 0 & 0 & 0 & 0 & 0 & 0 & 0 \\
\hline & Não & & & & & & & \\
\hline \multirow[t]{2}{*}{ TOTAL } & & 0 & 3 & 5 & 0 & 11 & 12 & 31 \\
\hline & & \multicolumn{2}{|c|}{3} & \multicolumn{2}{|c|}{5} & \multicolumn{2}{|c|}{23} & \\
\hline
\end{tabular}

b) Freqüências relativas em relação ao $\mathbf{N}$ total de cada tipo de ação com o objeto.

\begin{tabular}{|c|c|c|c|c|c|c|c|}
\hline \multirow{2}{*}{ Ocorrência de interação social após imitação } & & \multicolumn{2}{|c|}{ Ação usual com objeto } & \multicolumn{2}{|c|}{ Ação não usual com objeto } & \multicolumn{2}{|c|}{ Ação sem objeto* } \\
\hline & & Sim & Não & Sim & Não & Sim & Não \\
\hline \multirow[t]{2}{*}{ Tipo de brincadeira antes da imitação } & Conjunta & $0,0 \%$ & $33,3 \%$ & $60,0 \%$ & $0,0 \%$ & $39,1 \%$ & $34,8 \%$ \\
\hline & Solitária & $0,0 \%$ & $66,7 \%$ & $40,0 \%$ & $0,0 \%$ & $8,7 \%$ & $17,4 \%$ \\
\hline \multirow[t]{2}{*}{ Repetição da ação imitada*** } & Sim & $0,0 \%$ & $33,3 \%$ & $40,0 \%$ & $0,0 \%$ & $13,0 \%$ & $4,3 \%$ \\
\hline & Não & $0,0 \%$ & $66,7 \%$ & $60,0 \%$ & $0,0 \%$ & $34,8 \%$ & $47,8 \%$ \\
\hline \multirow[t]{2}{*}{ Repetição da ação imitada em outro episódio } & Sim & $0,0 \%$ & $0,0 \%$ & $0,0 \%$ & $0,0 \%$ & $0,0 \%$ & $4,3 \%$ \\
\hline & Não & & & & & & \\
\hline Repetição da ação imitada num outro dia & Não & & & & & & \\
\hline TOTAL & & $0,0 \%$ & $100,0 \%$ & $100,0 \%$ & $0,0 \%$ & $47,8 \%$ & $52,2 \%$ \\
\hline $\mathrm{N}$ & & \multicolumn{2}{|c|}{3} & \multicolumn{2}{|c|}{5} & \multicolumn{2}{|c|}{23} \\
\hline
\end{tabular}




\section{c) Freqüiências relativas em relação ao $\mathbf{N}$ total de imit ações (31).}

\begin{tabular}{|c|c|c|c|c|c|c|c|c|}
\hline \multirow[b]{2}{*}{ Ocorrência de interação social após imitação } & & \multicolumn{2}{|c|}{ Ação usual com objeto } & \multicolumn{2}{|c|}{ Ação não usual com objeto } & \multicolumn{2}{|c|}{ Ação sem objeto* } & \multirow{2}{*}{$\begin{array}{c}\text { TOTAL } \\
51,6 \%\end{array}$} \\
\hline & & Sim & Não & Sim & Não & Sim & Não & \\
\hline \multirow{2}{*}{ Tipo de brincadeira antes da imitação } & Conjunta & $0,0 \%$ & $3,2 \%$ & $9,7 \%$ & $0,0 \%$ & $29,0 \%$ & $25,8 \%$ & $67,7 \%$ \\
\hline & Solitária & $0,0 \%$ & $6,5 \%$ & $6,5 \%$ & $0,0 \%$ & $6,5 \%$ & $12,9 \%$ & $32,3 \%$ \\
\hline \multirow{2}{*}{ Repetição da ação imitada** } & Sim & $0,0 \%$ & $3,2 \%$ & $6,5 \%$ & $0,0 \%$ & $9,7 \%$ & $3,2 \%$ & $22,6 \%$ \\
\hline & Não & $0,0 \%$ & $6,5 \%$ & $9,7 \%$ & $0,0 \%$ & $25,8 \%$ & $35,5 \%$ & $77,4 \%$ \\
\hline \multirow{2}{*}{ Repetição da ação imitada em outro episódio } & Sim & $0,0 \%$ & $0,0 \%$ & $0,0 \%$ & $0,0 \%$ & $0,0 \%$ & $3,2 \%$ & $3,2 \%$ \\
\hline & Não & & & & & & & \\
\hline \multirow[t]{2}{*}{ Repetição da ação imitada num outro dia } & Sim & $0,0 \%$ & $0,0 \%$ & $0,0 \%$ & $0,0 \%$ & $0,0 \%$ & $0,0 \%$ & $0,0 \%$ \\
\hline & Não & & & & & & & \\
\hline TOTAL & & $0,0 \%$ & $9,7 \%$ & $16,1 \%$ & $0,0 \%$ & $35,5 \%$ & $38,7 \%$ & $100,0 \%$ \\
\hline
\end{tabular}

Notas: $*$ o imitado pode ser um gesto, um movimento, uma vocalização, uma verbalização etc (se houver objeto, ele não é foco da imitação).

** = a mesma criança que imitou repete a ação imitada (no mesmo episódio de brincadeira); evidência de aprendizagem. 
APÊNDICE 21 - Dados sobre imitação obtidos nos focais intermediários (quatro) das crianças A, C, Gi, H, La e S (total: 24 focais; 120 a) Freqüências absolutas. minutos; período de 25/3-28/4/04). Ver “notas"na próxima página.

\begin{tabular}{|c|c|c|c|c|c|c|c|c|}
\hline \multirow{2}{*}{ Ocorrência de interação social após imitação } & & \multicolumn{2}{|c|}{ Ação usual com objeto } & \multicolumn{2}{|c|}{ Ação não usual com objeto } & \multicolumn{2}{|c|}{ Ação sem objeto* } & \multirow{2}{*}{$\begin{array}{c}\text { TOTAL } \\
12 \\
\end{array}$} \\
\hline & & Sim & Não & Sim & Não & Sim & Não & \\
\hline \multirow[t]{2}{*}{ Tipo de brincadeira antes da imitação } & Conjunta & 1 & 0 & 1 & 1 & 6 & 0 & 9 \\
\hline & Solitária & 0 & 3 & 2 & 5 & 2 & 0 & 12 \\
\hline \multirow[t]{2}{*}{ Repetição da ação imitada*** } & Sim & 0 & 1 & 1 & 0 & 1 & 0 & 3 \\
\hline & Não & 1 & 2 & 2 & 6 & 7 & 0 & 18 \\
\hline \multirow[t]{2}{*}{ Repetição da ação imitada em outro episódio } & Sim & 0 & 0 & 0 & 0 & 0 & 0 & 0 \\
\hline & Não & & & & & & & \\
\hline \multirow[t]{2}{*}{ Repetição da ação imitada num outro dia } & Sim & 0 & 0 & 0 & 0 & 0 & 0 & 0 \\
\hline & Não & & & & & & & \\
\hline \multirow[t]{2}{*}{ TOTAL } & & 1 & 3 & 3 & 6 & 8 & & 21 \\
\hline & & \multicolumn{2}{|c|}{4} & \multicolumn{2}{|c|}{9} & \multicolumn{2}{|c|}{8} & \\
\hline
\end{tabular}

b) Frequiências relativas em relação ao $\mathrm{N}$ total de cada tipo de ação com o objeto.

\begin{tabular}{|c|c|c|c|c|c|c|c|}
\hline \multirow{2}{*}{ Ocorrência de interação social após imitação } & & \multicolumn{2}{|c|}{ Ação usual com objeto } & \multicolumn{2}{|c|}{ Ação não usual com objeto } & \multicolumn{2}{|c|}{ Ação sem objeto* } \\
\hline & & Sim & Não & Sim & Não & Sim & Não \\
\hline \multirow[t]{2}{*}{ Tipo de brincadeira antes da imitação } & Conjunta & $25,0 \%$ & $0,0 \%$ & $11,1 \%$ & $11,1 \%$ & $75,0 \%$ & $0,0 \%$ \\
\hline & Solitária & $0,0 \%$ & $75,0 \%$ & $22,2 \%$ & $55,6 \%$ & $25,0 \%$ & $0,0 \%$ \\
\hline \multirow{2}{*}{ Repetição da ação imitada*** } & Sim & $0,0 \%$ & $25,0 \%$ & $11,1 \%$ & $0,0 \%$ & $12,5 \%$ & $0,0 \%$ \\
\hline & Não & $25,0 \%$ & $50,0 \%$ & $22,2 \%$ & $66,7 \%$ & $87,5 \%$ & $0,0 \%$ \\
\hline \multirow[t]{2}{*}{ Repetição da ação imitada em outro episódio } & Sim & $0,0 \%$ & $0,0 \%$ & $0,0 \%$ & $0,0 \%$ & $0,0 \%$ & $0,0 \%$ \\
\hline & Não & & & & & & \\
\hline \multirow[t]{2}{*}{ Repetição da ação imitada num outro dia } & Sim & $0,0 \%$ & $0,0 \%$ & & $0,0 \%$ & $0,0 \%$ & $0,0 \%$ \\
\hline & Não & & & & & & \\
\hline TOTAL & & $25,0 \%$ & $75,0 \%$ & $33,3 \%$ & $66,7 \%$ & $100,0 \%$ & $0,0 \%$ \\
\hline $\mathbf{N}$ & & \multicolumn{2}{|c|}{4} & \multicolumn{2}{|c|}{9} & \multicolumn{2}{|c|}{8} \\
\hline
\end{tabular}


c) Freqüiências relativas em relação ao $\mathbf{N}$ total de imit ações (21).

\begin{tabular}{|c|c|c|c|c|c|c|c|c|}
\hline \multirow[b]{2}{*}{ Ocorrência de interação social após imitação } & & \multicolumn{2}{|c|}{ Ação usual com objeto } & \multicolumn{2}{|c|}{ Ação não usual com objeto } & \multicolumn{2}{|c|}{ Ação sem objeto* } & \multirow{2}{*}{$\begin{array}{c}\text { TOTAL } \\
57,1 \%\end{array}$} \\
\hline & & Sim & Não & Sim & Não & Sim & Não & \\
\hline \multirow{2}{*}{ Tipo de brincadeira antes da imitação } & Conjunta & $4,8 \%$ & $0,0 \%$ & $4,8 \%$ & $4,8 \%$ & $28,6 \%$ & $0,0 \%$ & $42,9 \%$ \\
\hline & Solitária & $0,0 \%$ & $14,3 \%$ & $9,5 \%$ & $23,8 \%$ & $9,5 \%$ & $0,0 \%$ & $57,1 \%$ \\
\hline \multirow[t]{2}{*}{ Repetição da ação imitada** } & Sim & $0,0 \%$ & $4,8 \%$ & $4,8 \%$ & $0,0 \%$ & $4,8 \%$ & $0,0 \%$ & $14,3 \%$ \\
\hline & Não & $4,8 \%$ & $9,5 \%$ & $9,5 \%$ & $28,6 \%$ & $33,3 \%$ & $0,0 \%$ & $85,7 \%$ \\
\hline \multirow[t]{2}{*}{ Repetição da ação imitada em outro episódio } & Sim & $0,0 \%$ & $0,0 \%$ & $0,0 \%$ & $0,0 \%$ & $0,0 \%$ & $0,0 \%$ & $0,0 \%$ \\
\hline & Não & & & & & & & \\
\hline \multirow[t]{2}{*}{ Repetição da ação imitada num outro dia } & Sim & $0,0 \%$ & $0,0 \%$ & $0,0 \%$ & $0,0 \%$ & $0,0 \%$ & $0,0 \%$ & $0,0 \%$ \\
\hline & Não & & & & & & & \\
\hline TOTAL & & $4,8 \%$ & $14,3 \%$ & $14,3 \%$ & $28,6 \%$ & $38,1 \%$ & $0,0 \%$ & $100,0 \%$ \\
\hline
\end{tabular}

Notas: $*$ o imitado pode ser um gesto, um movimento, uma vocalização, uma verbalização etc (se houver objeto, ele não é foco da imitação).

** = a mesma criança que imitou repete a ação imitada (no mesmo episódio de brincadeira); evidência de aprendizagem. 
APÊNDICE 22 - Dados sobre imitação obtidos nos focais finais (quatro últimos) das crianças A, C, Gi, H, La e S (total: 24 focais; 120 a) Freqüências absolutas. minutos; período de 13/10-16/11/04). Ver "notas"na próxima página.

\begin{tabular}{|c|c|c|c|c|c|c|c|c|}
\hline \multirow[b]{2}{*}{ Ocorrência de interação social após imitação } & & \multicolumn{2}{|c|}{ Ação usual com objeto } & \multicolumn{2}{|c|}{ Ação não usual com objeto } & \multicolumn{2}{|c|}{ Ação sem objeto* } & \multirow{2}{*}{$\begin{array}{c}\text { TOTAL } \\
28 \\
\end{array}$} \\
\hline & & Sim & Não & Sim & Não & Sim & Não & \\
\hline \multirow{2}{*}{ Tipo de brincadeira antes da imitação } & Conjunta & 2 & 0 & 4 & 0 & 20 & 0 & 26 \\
\hline & Solitária & 0 & 2 & 2 & 3 & 0 & 3 & 10 \\
\hline \multirow{2}{*}{ Repetição da ação imitada** } & Sim & 0 & 0 & 3 & 0 & 2 & 0 & 5 \\
\hline & Não & 2 & 2 & 3 & 3 & 18 & 3 & 31 \\
\hline \multirow{2}{*}{ Repetição da ação imitada em outro episódio } & Sim & 0 & 0 & 1 & 0 & 0 & 0 & 1 \\
\hline & Não & & & & & & & 0 \\
\hline \multirow{2}{*}{ Repetição da ação imitada num outro dia } & Sim & 0 & 0 & 1 & 0 & 0 & 0 & 1 \\
\hline & Não & & & & & & & 0 \\
\hline \multirow[t]{2}{*}{ TOTAL } & & 2 & 2 & 6 & 3 & 20 & 3 & 36 \\
\hline & & \multicolumn{2}{|c|}{4} & \multicolumn{2}{|c|}{9} & \multicolumn{2}{|c|}{23} & \\
\hline
\end{tabular}

b) Frequiências relativas em relação ao $\mathbf{N}$ total de cada tipo de ação com o objeto.

\begin{tabular}{|c|c|c|c|c|c|c|c|}
\hline \multirow{2}{*}{ Ocorrência de interação social após imitação } & & \multicolumn{2}{|c|}{ Ação usual com objeto } & \multicolumn{2}{|c|}{ Ação não usual com objeto } & \multicolumn{2}{|c|}{ Ação sem objeto* } \\
\hline & & Sim & Não & Sim & Não & Sim & Não \\
\hline \multirow{2}{*}{ Tipo de brincadeira antes da imitação } & Conjunta & $50,0 \%$ & $0,0 \%$ & $44,4 \%$ & $0,0 \%$ & $87,0 \%$ & $0,0 \%$ \\
\hline & Solitária & $0,0 \%$ & $50,0 \%$ & $22,2 \%$ & $33,3 \%$ & $0,0 \%$ & $13,0 \%$ \\
\hline \multirow{2}{*}{ Repetição da ação imitada** } & Sim & $0,0 \%$ & $0,0 \%$ & $33,3 \%$ & $0,0 \%$ & $8,7 \%$ & $0,0 \%$ \\
\hline & Não & $50,0 \%$ & $50,0 \%$ & $33,3 \%$ & $33,3 \%$ & $78,3 \%$ & $13,0 \%$ \\
\hline \multirow{2}{*}{ Repetição da ação imitada em outro episódio } & Sim & $0,0 \%$ & $0,0 \%$ & $11,1 \%$ & $0,0 \%$ & $0,0 \%$ & $0,0 \%$ \\
\hline & Não & & & & & & \\
\hline Repetição da ação imitada num outro dia & Não & & & & & & \\
\hline TOTAL & & $50,0 \%$ & $50,0 \%$ & $66,7 \%$ & $33,3 \%$ & $87,0 \%$ & $13,0 \%$ \\
\hline $\mathbf{N}$ & & \multicolumn{2}{|c|}{4} & \multicolumn{2}{|c|}{9} & \multicolumn{2}{|c|}{23} \\
\hline
\end{tabular}


c) Freqüiências relativas em relação ao $\mathbf{N}$ total de imit ações (36).

\begin{tabular}{|c|c|c|c|c|c|c|c|c|}
\hline \multirow[b]{2}{*}{ Ocorrência de interação social após imitação } & & \multicolumn{2}{|c|}{ Ação usual com objeto } & \multicolumn{2}{|c|}{ Ação não usual com objeto } & \multicolumn{2}{|c|}{ Ação sem objeto* } & \multirow{2}{*}{$\frac{\text { TOTAL }}{77,8 \%}$} \\
\hline & & Sim & Não & Sim & Não & Sim & Não & \\
\hline \multirow{2}{*}{ Tipo de brincadeira antes da imitação } & Conjunta & $5,6 \%$ & $0,0 \%$ & $11,1 \%$ & $0,0 \%$ & $55,6 \%$ & $0,0 \%$ & $72,2 \%$ \\
\hline & Solitária & $0,0 \%$ & $5,6 \%$ & $5,6 \%$ & $8,3 \%$ & $0,0 \%$ & $8,3 \%$ & $27,8 \%$ \\
\hline \multirow{2}{*}{ Repetição da ação imitada*** } & Sim & $0,0 \%$ & $0,0 \%$ & $8,3 \%$ & $0,0 \%$ & $5,6 \%$ & $0,0 \%$ & $13,9 \%$ \\
\hline & Não & $5,6 \%$ & $5,6 \%$ & $8,3 \%$ & $8,3 \%$ & $50,0 \%$ & $8,3 \%$ & $86,1 \%$ \\
\hline \multirow{2}{*}{ Repetição da ação imitada em outro episódio } & Sim & $0,0 \%$ & $0,0 \%$ & $2,8 \%$ & $0,0 \%$ & $0,0 \%$ & $0,0 \%$ & $2,8 \%$ \\
\hline & Não & & & & & & & $0,0 \%$ \\
\hline \multirow{2}{*}{ Repetição da ação imitada num outro dia } & Sim & $0,0 \%$ & $0,0 \%$ & $2,8 \%$ & $0,0 \%$ & $0,0 \%$ & $0,0 \%$ & $2,8 \%$ \\
\hline & Não & & & & & & & $0,0 \%$ \\
\hline TOTAL & & $5,6 \%$ & $5,6 \%$ & $16,7 \%$ & $8,3 \%$ & $55,6 \%$ & $8,3 \%$ & $100,0 \%$ \\
\hline
\end{tabular}

Notas: * = o imitado pode ser um gesto, um movimento, uma vocalização, uma verbalização etc (se houver objeto, ele não é foco da imitação).

** = a mesma criança que imitou repete a ação imitada (no mesmo episódio de brincadeira); evidência de aprendizagem. 
APÊNDICE 23 - Dados sobre imitação obtidos nas duplas iniciais das crianças A, C, Gi, Gu, H, La e S (total: 13 duplas; 130 minutos; meses 3, 5 e 6/04). Ver "notas"na próxima página.

a) Freqüiências absolutas.

\begin{tabular}{|c|c|c|c|c|c|c|c|c|}
\hline \multirow[b]{2}{*}{ Ocorrência de interação social após imitação } & & \multicolumn{2}{|c|}{ Ação usual com objeto } & \multicolumn{2}{|c|}{ Ação não usual com objeto } & \multicolumn{2}{|c|}{ Ação sem objeto* } & \multirow{2}{*}{\begin{tabular}{|c} 
TOTAL \\
26
\end{tabular}} \\
\hline & & Sim & Não & Sim & Não & Sim & Não & \\
\hline \multirow{2}{*}{ Tipo de brincadeira antes da imitação } & Conjunta & 6 & 4 & 5 & 1 & 5 & 2 & 23 \\
\hline & Solitária & 5 & 8 & 4 & 4 & 1 & 2 & 24 \\
\hline \multirow{2}{*}{ Repetição da ação imitada** } & Sim & 2 & 4 & 2 & 1 & 0 & 1 & 10 \\
\hline & Não & 9 & 8 & 7 & 4 & 6 & 3 & 37 \\
\hline \multirow{2}{*}{ Repetição da ação imitada em outro episódio } & Sim & 0 & 1 & 1 & 2 & 0 & 0 & 4 \\
\hline & Não & & & & & & & \\
\hline \multirow{2}{*}{ Repetição da ação imitada num outro dia } & Sim & 0 & 0 & 1 & 2 & 0 & 0 & 3 \\
\hline & Não & & & & & & & \\
\hline \multirow[t]{2}{*}{ TOTAL } & & 11 & 12 & 9 & 5 & 6 & 4 & 47 \\
\hline & & \multicolumn{2}{|c|}{23} & \multicolumn{2}{|c|}{14} & \multicolumn{2}{|c|}{10} & \\
\hline
\end{tabular}

b) Frequiências relativas em relação ao $\mathbf{N}$ total de cada tipo de ação com o objeto.

\begin{tabular}{|c|c|c|c|c|c|c|c|}
\hline \multirow[b]{2}{*}{ Ocorrência de interação social após imitação } & & \multicolumn{2}{|c|}{ Ação usual com objeto } & \multicolumn{2}{|c|}{ Ação não usual com objeto } & \multicolumn{2}{|c|}{ Ação sem objeto* } \\
\hline & & Sim & Não & Sim & Não & Sim & Não \\
\hline \multirow{2}{*}{ Tipo de brincadeira antes da imitação } & Conjunta & $26,1 \%$ & $17,4 \%$ & $35,7 \%$ & $7,1 \%$ & $50,0 \%$ & $20,0 \%$ \\
\hline & Solitária & $21,7 \%$ & $34,8 \%$ & $28,6 \%$ & $28,6 \%$ & $10,0 \%$ & $20,0 \%$ \\
\hline \multirow{2}{*}{ Repetição da ação imitada** } & Sim & $8,7 \%$ & $17,4 \%$ & $14,3 \%$ & $7,1 \%$ & $0,0 \%$ & $10,0 \%$ \\
\hline & Não & $39,1 \%$ & $34,8 \%$ & $50,0 \%$ & $28,6 \%$ & $60,0 \%$ & $30,0 \%$ \\
\hline \multirow{2}{*}{ Repetição da ação imitada em outro episódio } & Sim & $0,0 \%$ & $4,3 \%$ & $7,1 \%$ & $14,3 \%$ & $0,0 \%$ & $0,0 \%$ \\
\hline & Não & & & & & & \\
\hline \multirow{2}{*}{ Repetição da ação imitada num outro dia } & Sim & $0,0 \%$ & $0,0 \%$ & $7,1 \%$ & $14,3 \%$ & $0,0 \%$ & $0,0 \%$ \\
\hline & Não & & & & & & \\
\hline TOTAL & & $47,8 \%$ & $52,2 \%$ & $64,3 \%$ & $35,7 \%$ & $60,0 \%$ & $40,0 \%$ \\
\hline $\mathbf{N}$ & & \multicolumn{2}{|c|}{23} & \multicolumn{2}{|c|}{14} & \multicolumn{2}{|c|}{10} \\
\hline
\end{tabular}


c) Freqüiências relativas em relação ao $\mathbf{N}$ total de imit ações (47).

\begin{tabular}{|c|c|c|c|c|c|c|c|c|}
\hline \multirow[b]{2}{*}{ Ocorrência de interação social após imitação } & & \multicolumn{2}{|c|}{ Ação usual com objeto } & \multicolumn{2}{|c|}{ Ação não usual com objeto } & \multicolumn{2}{|c|}{ Ação sem objeto* } & \multirow{2}{*}{\begin{tabular}{|r|} 
TOTAL \\
$55,3 \%$ \\
\end{tabular}} \\
\hline & & Sim & Não & Sim & Não & Sim & Não & \\
\hline \multirow{2}{*}{ Tipo de brincadeira antes da imitação } & Conjunta & $12,8 \%$ & $8,5 \%$ & $10,6 \%$ & $2,1 \%$ & $10,6 \%$ & $4,3 \%$ & $48,9 \%$ \\
\hline & Solitária & $10,6 \%$ & $17,0 \%$ & $8,5 \%$ & $8,5 \%$ & $2,1 \%$ & $4,3 \%$ & $51,1 \%$ \\
\hline \multirow{2}{*}{ Repetição da ação imitada** } & Sim & $4,3 \%$ & $8,5 \%$ & $4,3 \%$ & $2,1 \%$ & $0,0 \%$ & $2,1 \%$ & $21,3 \%$ \\
\hline & Não & $19,1 \%$ & $17,0 \%$ & $14,9 \%$ & $8,5 \%$ & $12,8 \%$ & $6,4 \%$ & $78,7 \%$ \\
\hline \multirow{2}{*}{ Repetição da ação imitada em outro episódio } & Sim & $0,0 \%$ & $2,1 \%$ & $2,1 \%$ & $4,3 \%$ & $0,0 \%$ & $0,0 \%$ & $8,5 \%$ \\
\hline & Não & & & & & & & \\
\hline \multirow{2}{*}{ Repetição da ação imitada num outro dia } & Sim & $0,0 \%$ & $0,0 \%$ & $2,1 \%$ & $4,3 \%$ & $0,0 \%$ & $0,0 \%$ & $6,4 \%$ \\
\hline & Não & & & & & & & \\
\hline TOTAL & & $23,4 \%$ & $25,5 \%$ & $19,1 \%$ & $10,6 \%$ & $12,8 \%$ & $8,5 \%$ & $100,0 \%$ \\
\hline
\end{tabular}

Notas: * = imitado pode ser um gesto, um movimento, uma vocalização, uma verbalização etc (se houver objeto, ele não é foco da imitação).

** = a mesma criança que imitou repete a ação imitada (no mesmo episódio de brincadeira); evidência de aprendizagem. 
APÊNDICE 24 - Dados sobre imitação obtidos nas duplas finais das crianças A, C, Gi, Gu, H, La e S (total: 15 duplas; 150 minutos; meses 7, 9 e 11/04). Ver "notas"na próxima página.

a) Freqüiências absolutas.

\begin{tabular}{|c|c|c|c|c|c|c|c|c|}
\hline \multirow[b]{2}{*}{ Ocorrência de interação social após imitação } & 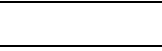 & \multicolumn{2}{|c|}{ Ação usual com objeto } & \multicolumn{2}{|c|}{ Ação não usual com objeto } & \multicolumn{2}{|c|}{ Ação sem objeto* } & \multirow{2}{*}{$\begin{array}{c}\text { TOTAL } \\
35\end{array}$} \\
\hline & & Sim & Não & Sim & Não & Sim & Não & \\
\hline \multirow{2}{*}{ Tipo de brincadeira antes da imitação } & Conjunta & 2 & 2 & 9 & 4 & 9 & 1 & 27 \\
\hline & Solitária & 3 & 8 & 9 & 14 & 3 & 3 & 40 \\
\hline \multirow{2}{*}{ Repetição da ação imitada** } & Sim & 1 & & 6 & 1 & & & 8 \\
\hline & Não & 4 & 10 & 12 & 18 & 12 & 4 & 60 \\
\hline \multirow{2}{*}{ Repetição da ação imitada em outro episódio } & Sim & & 1 & & 2 & 1 & & 4 \\
\hline & Não & & & & & & & 0 \\
\hline \multirow{2}{*}{ Repetição da ação imitada num outro dia } & Sim & & 1 & & 1 & 1 & & 3 \\
\hline & Não & & & & & & & 0 \\
\hline \multirow[t]{2}{*}{ TOTAL } & & 5 & 10 & 18 & 18 & 12 & 4 & 67 \\
\hline & & \multicolumn{2}{|c|}{15} & \multicolumn{2}{|c|}{36} & \multicolumn{2}{|c|}{16} & \\
\hline
\end{tabular}

b) Freqüiências relativas em relação ao $\mathrm{N}$ total de cada tipo de ação com o objeto.

\begin{tabular}{|c|c|c|c|c|c|c|c|}
\hline \multirow[b]{2}{*}{ Ocorrência de interação social após imitação } & & \multicolumn{2}{|c|}{ Ação usual com objeto } & \multicolumn{2}{|c|}{ Ação não usual com objeto } & \multicolumn{2}{|c|}{ Ação sem objeto* } \\
\hline & & Sim & Não & Sim & Não & Sim & Não \\
\hline \multirow{2}{*}{ Tipo de brincadeira antes da imitação } & Conjunta & $13,3 \%$ & $13,3 \%$ & $25,0 \%$ & $11,1 \%$ & $56,3 \%$ & $6,3 \%$ \\
\hline & Solitária & $20,0 \%$ & $53,3 \%$ & $25,0 \%$ & $38,9 \%$ & $18,8 \%$ & $18,8 \%$ \\
\hline \multirow{2}{*}{ Repetição da ação imitada** } & Sim & $6,7 \%$ & $0,0 \%$ & $16,7 \%$ & $2,8 \%$ & $0,0 \%$ & $0,0 \%$ \\
\hline & Não & $26,7 \%$ & $66,7 \%$ & $33,3 \%$ & $50,0 \%$ & $75,0 \%$ & $25,0 \%$ \\
\hline \multirow{2}{*}{ Repetição da ação imitada em outro episódio } & Sim & $0,0 \%$ & $6,7 \%$ & $0,0 \%$ & $5,6 \%$ & $6,3 \%$ & $0,0 \%$ \\
\hline & Não & & & & & & \\
\hline \multirow{2}{*}{ Repetição da ação imitada num outro dia } & Sim & $0,0 \%$ & $6,7 \%$ & $0,0 \%$ & $2,8 \%$ & $6,3 \%$ & $0,0 \%$ \\
\hline & Não & & & & & & \\
\hline TOTAL & & $33,3 \%$ & $66,7 \%$ & $50,0 \%$ & $50,0 \%$ & $75,0 \%$ & $25,0 \%$ \\
\hline $\mathbf{N}$ & & \multicolumn{2}{|c|}{15} & \multicolumn{2}{|c|}{36} & \multicolumn{2}{|c|}{16} \\
\hline
\end{tabular}


c) Freqüiências relativas em relação ao $\mathbf{N}$ total de imit ações (67).

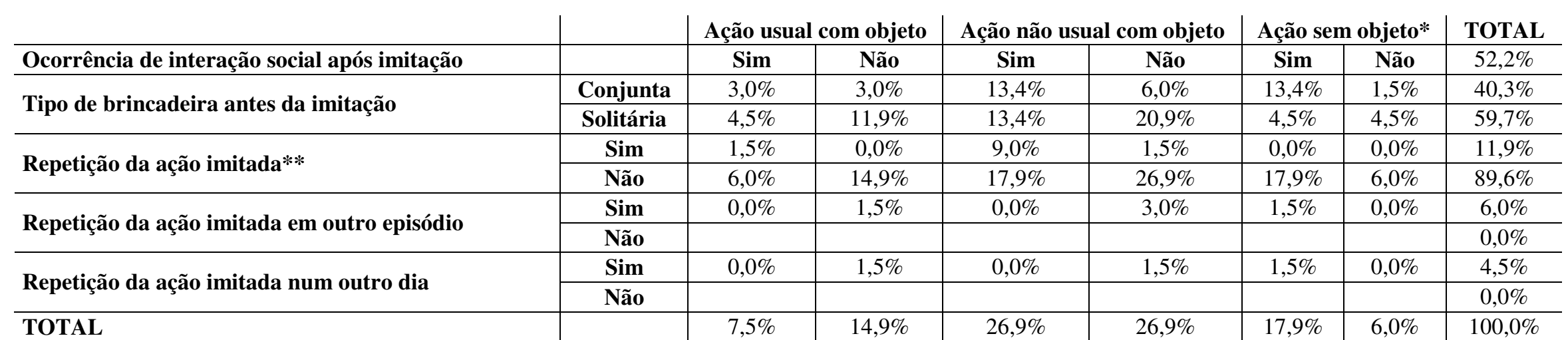

Notas: * o imitado pode ser um gesto, um movimento, uma vocalização, uma verbalização etc (se houver objeto, ele não é foco da imitação).

** = a mesma criança que imitou repete a ação imitada (no mesmo episódio de brincadeira); evidência de aprendizagem. 
APÊNDICE 25 - Dados sobre imitação obtidos nas duas sessões conjuntas das crianças A, C, Gi, Gu, H, La, Li e S (total: 8 crianças; a) Freqüências absolutas.

40 minutos; dia 16/12/04).

\begin{tabular}{|c|c|c|c|c|c|c|c|c|}
\hline \multirow[b]{2}{*}{ Ocorrência de interação social após imitação } & & \multicolumn{2}{|c|}{ Ação usual com objeto } & \multicolumn{2}{|c|}{ Ação não usual com objeto } & \multicolumn{2}{|c|}{ Ação sem objeto* } & \multirow{2}{*}{$\begin{array}{c}\text { TOTAL } \\
0\end{array}$} \\
\hline & & Sim & Não & Sim & Não & Sim & Não & \\
\hline \multirow{2}{*}{ Tipo de brincadeira antes da imitação } & Conjunta & 0 & 0 & 0 & 0 & 0 & 1 & 1 \\
\hline & Solitária & 0 & 3 & 0 & 2 & 0 & 0 & 5 \\
\hline \multirow{2}{*}{ Repetição da ação imitada na mesma sessão } & Sim & 0 & 0 & 0 & 0 & 0 & 0 & 0 \\
\hline & Não & 0 & 3 & 0 & 2 & 0 & 1 & 6 \\
\hline \multirow{2}{*}{ Repetição da ação imitada na outra sessão conjunta } & Sim & 0 & 0 & 0 & 0 & 0 & 0 & 0 \\
\hline & Não & & & & & & & \\
\hline \multirow{2}{*}{ Repetição de ação imitada nas duplas } & Sim & 0 & 2 & 2 & 0 & 1 & 0 & 5 \\
\hline & Não & & & & & & & \\
\hline TOTAL & & 0 & 3 & 0 & 2 & 0 & 1 & 6 \\
\hline
\end{tabular}

Nota: * = o imitado pode ser um gesto, um movimento, uma vocalização, uma verbalização etc (se houver objeto, ele não é foco da imitação) 